Portland State University

PDXScholar

6-1-2002

\title{
Hydrogeologic Investigation of the Klamath Marsh, Klamath County, Oregon
}

Jason Michael Melady

Portland State University

Follow this and additional works at: https://pdxscholar.library.pdx.edu/open_access_etds Let us know how access to this document benefits you.

\section{Recommended Citation}

Melady, Jason Michael, "Hydrogeologic Investigation of the Klamath Marsh, Klamath County, Oregon" (2002). Dissertations and Theses. Paper 753.

https://doi.org/10.15760/etd.753

This Thesis is brought to you for free and open access. It has been accepted for inclusion in Dissertations and Theses by an authorized administrator of PDXScholar. Please contact us if we can make this document more accessible: pdxscholar@pdx.edu. 


\section{THESIS APPROVAL}

The abstract and thesis of Jason Michael Melady for the Master of Science in

Geohydrology presented June 12, 2002, and accepted by the thesis committee and the department.

COMMITTEE APPROVALS:

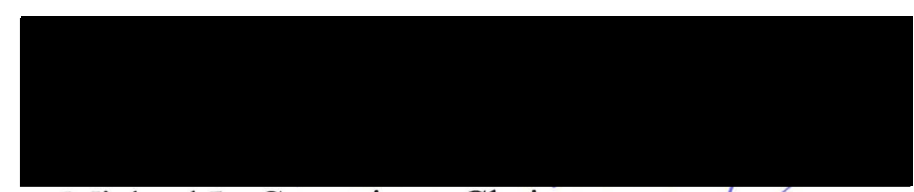

Michael L. Cummings, Chair

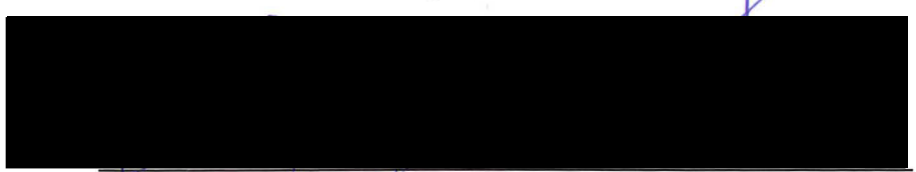

Ansel G. Johnson

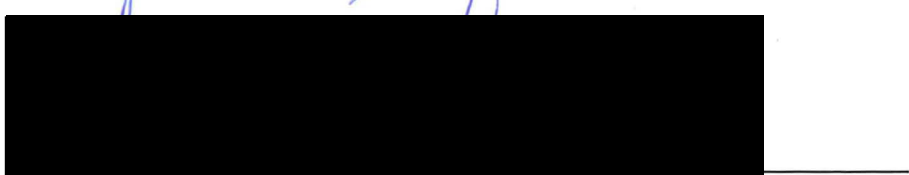

Martin J. Streck

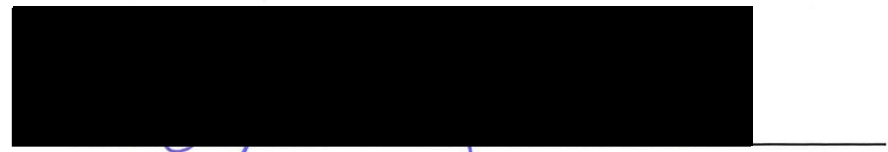

Roy W. Koch

Representative of the Office of Graduate Studies

DEPARTMENTAL APPROVAL

Michael L. Cummings, Chair Department of Geology

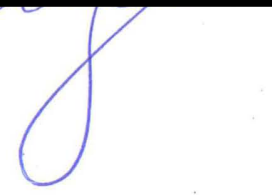




\begin{abstract}
An abstract of the thesis of Jason Michael Melady for the Master of Science in Geohydrology presented June 12, 2002.
\end{abstract}

Title: Hydrogeologic Investigation of the Klamath Marsh, Klamath County, Oregon.

Klamath Marsh is a wetland complex that lies in the rain shadow of the Cascade Range in the Williamson River sub-basin of the Klamath Basin. The marsh lies directly east of Crater Lake in an area inundated by pyroclastic-flow and -fall deposits from the Holocene eruptions of Mount Mazama. The physical characteristics of rocks of Pleistocene versus Pliocene age combined with NNW-striking fault systems divide the Williamson River basin into two distinct hydrogeologic regimes. The northwestern regime includes the east slope of the Cascades and consists of at least $150 \mathrm{~m}$ of interbedded sand, gravel, and stacks (15 to $45 \mathrm{~m}$ ) of thin (3-5 m) and vesiculated basalt lava flows. Mean annual precipitation ranges from $150 \mathrm{~cm}$ near the crest of the Cascades to $50 \mathrm{~cm}$ near Klamath Marsh. Moderate to high yield (100 to $4000 \mathrm{gpm}$ ) water wells, springs and flowing wells suggest high permeability and ground water potential. The southeastern regime is underlain by Pliocene pyroclastic flows $(\sim 40 \mathrm{~m})$ and lava flows $(>30 \mathrm{~m})$. Mean annual precipitation ranges from $70 \mathrm{~cm}$ in the highlands to $50 \mathrm{~cm}$ in the lowlands. Low-yield (20-100 gpm) water wells and perched unconfined aquifers in Holocene pumice deposits suggest low permeability and low ground water potential in areas underlain by the pyroclastic flows. Volumetric analysis of inflows and outflows in Klamath Marsh for 2000 indicates approximately $86 \%$ of inflow is from 
groundwater and $14 \%$ from surface water, with nearly $200 \times 10^{6} \mathrm{~m}^{3}$ of water removed by evapotranspiration. 
HYDROGEOLOGIC INVESTIGATION OF THE KLAMATH MARSH, KLAMATH COUNTY, OREGON

by

JASON MICHAEL MELADY

A thesis submitted in partial fulfillment of the requirements for the degree of

\section{MASTER OF SCIENCE \\ in \\ GEOHYDROLOGY}

Portland State University

2002 


\section{Acknowledgments}

This project was funded through the Oregon Resource Conservation Act administered under contract number 00FG200085 by the Bureau of Reclamation, MidPacific Region.

I would like to acknowledge the many people who have made this thesis possible. First, I would like to thank my advisor, Michael Cummings, for his assistance and guidance through this research. I would also like to thank Martin Streck for his assistance on INAA and David Percy for help with GIS questions and the infamous poster that went horribly wrong. A big thanks to my field assistant, Heather Bragg, for her help with geologic mapping and acquisition of the hydrologic data. Without her assistance, this project would have not been possible. I would also like to acknowledge Charlie Palmer and Jake Griffiths for field assistance during several trips to the marsh. I would like to thank Jeff Barry, Walter Burt, and Larry Eaton at Groundwater Solutions for help with many questions and financial stability for the last year. Finally, I would like to thank my partner, Megan Slack, for her support through the duration of this work. She has helped me to keep focus and has allowed me to keep my sanity. 


\section{Table of Contents}

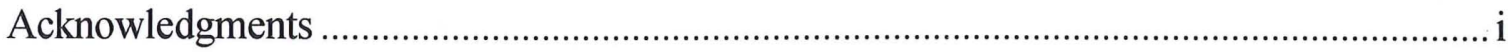

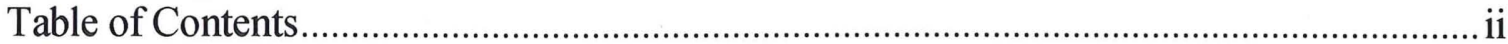

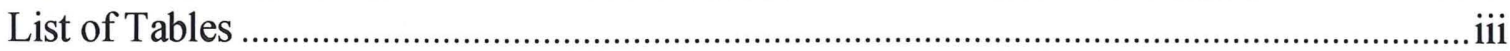

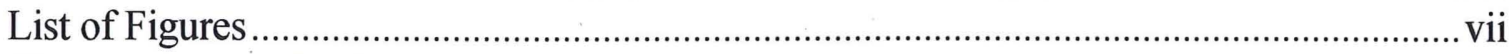

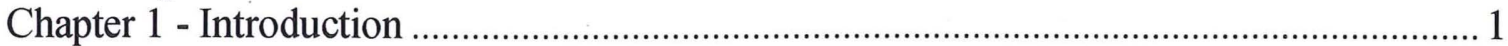

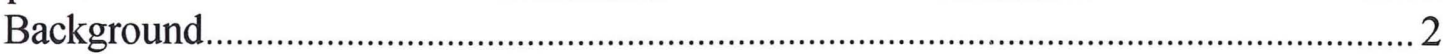

Climate (n)

Geology ………

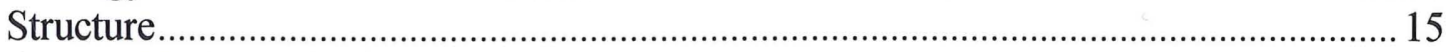

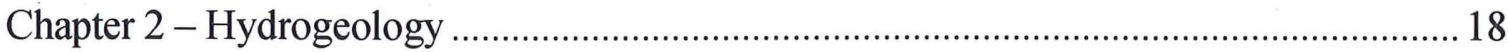

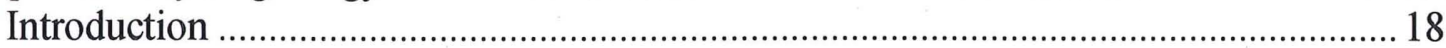

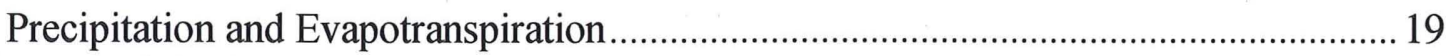

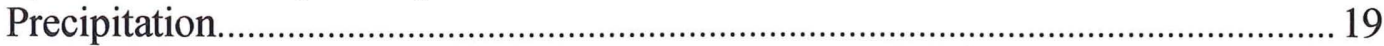

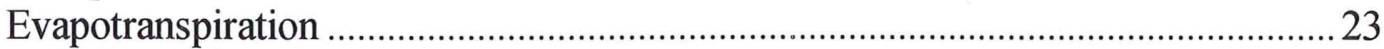

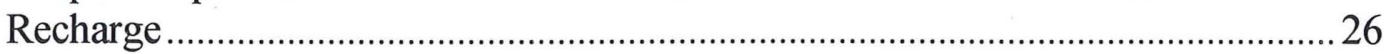

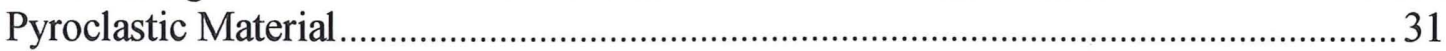

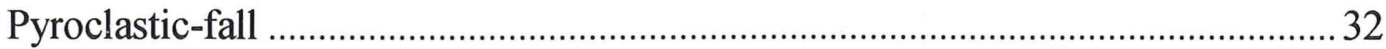

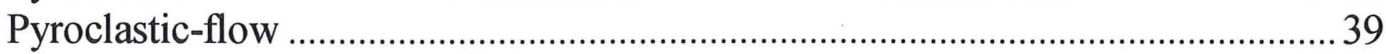

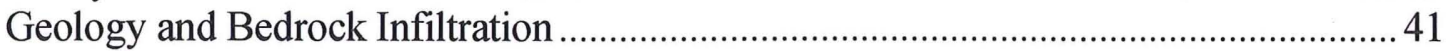

Upper Williamson River - (Area 1) .................................................................... 42

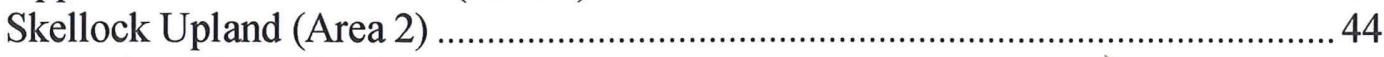

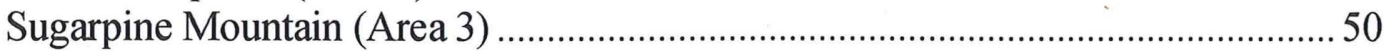

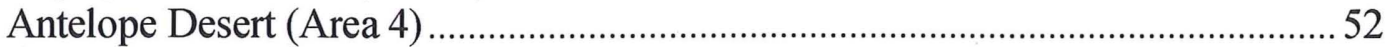

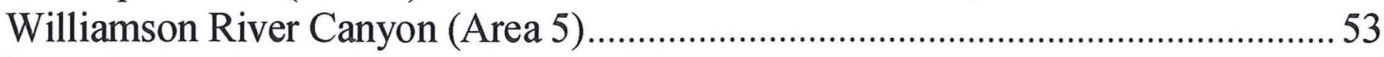

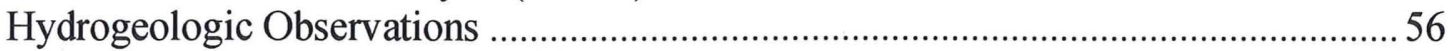

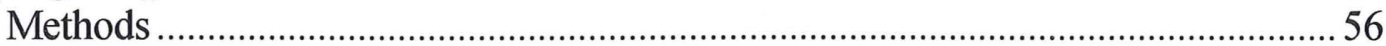

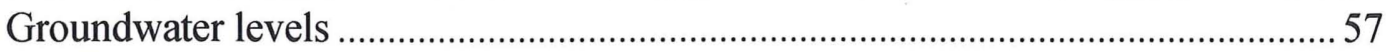

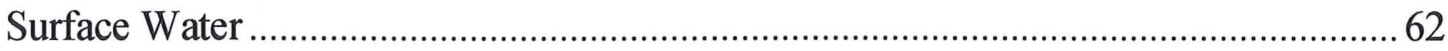

Relative In and Out Flow in Klamath Marsh ...................................................... 74

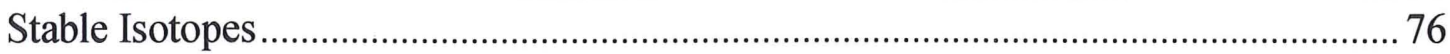

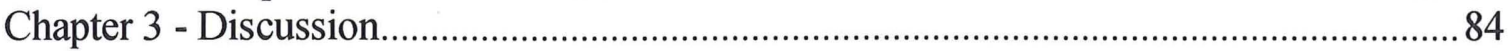

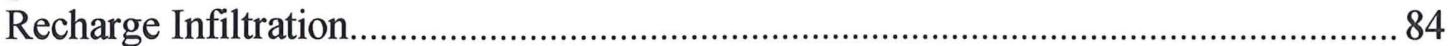

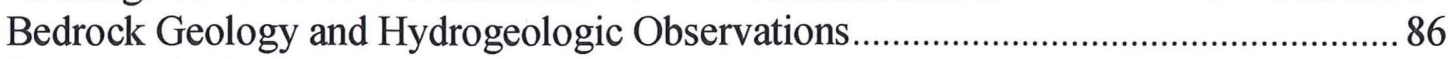

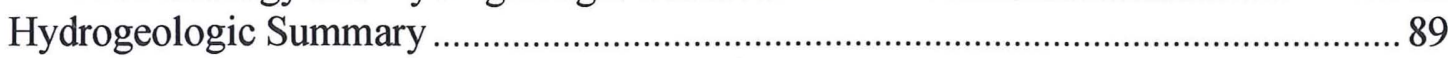

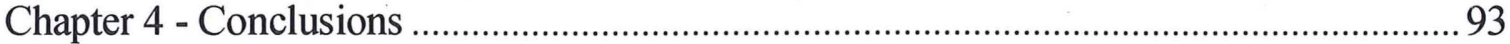

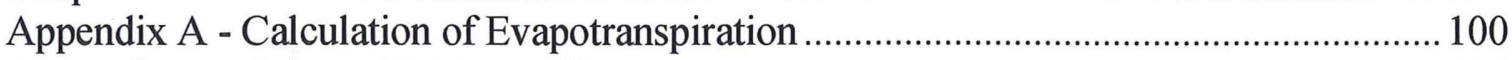

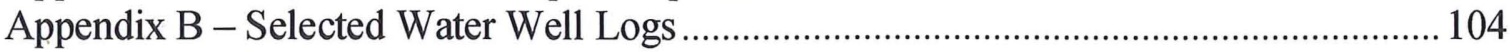

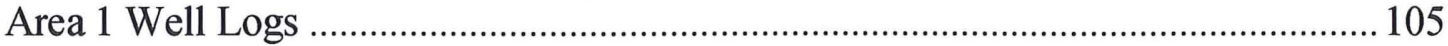

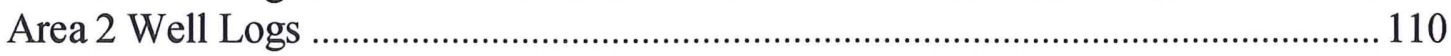

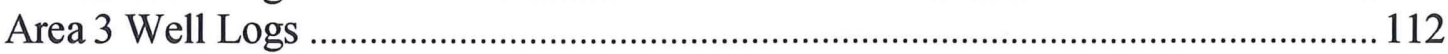

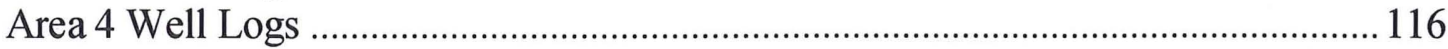

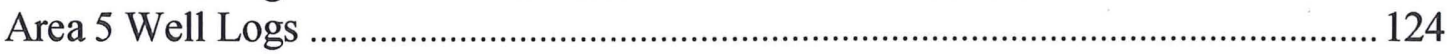




\section{List of Tables}

Number

Table 1 - Mean volume of precipitation, area, and spatially averaged precipitation in sub-areas.

Table 2 - Monthly average of daily evapotranspiration in millimeters per day at Sagebrush Point and Wocus Bay from Bidlake (1997), and Bidlake and Payne (1998), and Skellock Draw from this study. (N.C. $=$ not calculated, instrumentation was not installed until mid-June, 2000)

Table 3 - Temperature and evapotranspiration difference between Skellock Draw and Diamond Lake on 16-June-2000.

Table 4 - Sensitivity of evapotranspiration to $50 \%$ variation in meterological parameters. 28

Table 5 - Evapotranspiration (ET) volume using ET from this study $(52.1 \mathrm{~cm})$ and residual volume available for recharge. It should be noted that this ET represents only mid-June through late-October, so it is lower than ET for entire 2000 growing season.

Table 6 - Evapotranspiration volume using ET from Bidlake (1997) (average=68.4 cm) and residual volume available for recharge. 29

Table 7 - Evapotranspiration volume using ET from Bidlake and Payne (1998) (91.1 $\mathrm{cm})$ and residual volume available for recharge. 30

Table 8 - Ranking of sub-regions from highest to lowest precipitation volume after subtraction of evapotranspiration volume.

Table 9 - Correlation coefficient between each grain size and water percentage by weight. 38 
Table 10 - Bulk water percentage in all samples.

Table 11 - Values used for the estimation of infiltration rate of pyroclastic-flow material. 41

Table 12 - Summary of recharge, geology and water well yields in Area 1.

Table 13 - Summary of recharge, geology and water well yields in Area 2. 44

Table 14 - Parameters used to estimate hydraulic conductivity, hydraulic gradient, and cross-sectional area similarities among Jack Creek, Skellock Draw, and Yoss Meadow. Observations of pumice characteristics were made during installation of piezometers. Hydraulic gradient was determined by using piezometers at the upper and lower ends of each area. Thickness approximation is based on Conaway and Cummings (in press).

Table 15 - Rates of water level rise and decline in piezometers in Skellock Draw, Jack Creek, and Yoss Creek Meadow. Location of piezometers are shown in Figure 21 with letters keyed to Map ID in this table. Rates are in $\mathrm{cm}^{\text {day }}{ }^{-1}$ and indicate rate of water level change between dates shown at the top of each column. Negative values indicate a water level decline; positive values indicate water level was rising. N.D. $=$ water level not determined. Dry $=$ water level below bottom of piezometer.

Table 16 - Summary of recharge, geology and water well yields in Area 3.....................51

Table 17 - Summary of recharge, geology and water well yields in Area 4.....................53

Table 18 - Summary of recharge, geology and water well yields in Area 5.....................55

Table 19 - Water level below local ground surface in piezometers installed and monitored during 2000-2001. Map ID indicates location of piezometers keyed 
to Figure 21. Negative values indicate water level above ground surface. (N.D.

$=$ water level not determined)

Table 20 - Rate of water level change in Area 4 -Antelope Desert piezometers in cm day $^{-1}$. Map ID keyed to location on Figure 21. (N.D. = water level not determined)

Table 21 - Discharge $\left(\mathrm{m}^{3} \mathrm{~s}^{-1}\right)$ measurements in Area 1 - Upper Williamson River from 2000-2001 (N.D. = Discharge Not Determined). Location of gaging point is Map ID keyed toFigure 23. 63

Table 22 - Discharge $\left(\mathrm{m}^{3} \mathrm{~s}^{-1}\right)$ measurements in Area 2 - Skellock Upland and Area 3 -

Sugarpine Mountain during 2000-2001 (N.D. = Discharge Not Determined).

Location of gaging point is Map ID keyed to Figure 23. 64

Table 23 - Discharge $\left(\mathrm{m}^{3} \mathrm{~s}^{-1}\right)$ measurements in Area 4 - Antelope Desert during 2000-

2001 (N.D. = Discharge Not Determined). Location of gaging point is Map ID

keyed to Figure 23 66

Table 24 - Discharge $\left(\mathrm{m}^{3} \mathrm{~s}^{-1}\right)$ measurements in Area 5 - Lower Williamson River during 2000-2001 (N.D. $=$ Discharge Not Determined). Location of gaging point is

Map ID keyed to Figure 23 67

Table 25 - Water level measured from bridge tops at several locations on the

Williamson River and Klamath Marsh. Map ID location is keyed to Figure 23.

(N.D. $=$ water level not determined $)$ 72 
Table 26 - Volume of water flow into and out of Klamath Marsh from April 30, 2000 to April 27, 2001. Negative value for evapotranspiration indicates that the volume of water was removed from Klamath Marsh. 75

Table $27-\delta \mathrm{D}$ and $\delta^{18} \mathrm{O}$ stable isotopes at selected springs and streams near Klamath Marsh. Analysis completed by Geochron Laboratories in Cambridge, Massachusetts. 


\section{List of Figures}

Number

Figure 1 - General location map of features in the Williamson River basin. 2

Figure 2 - Location of Klamath Marsh and vicinity. 5

Figure 3 - Mean monthly precipitation from 1940-2000 at Chemult, Oregon (NOAA, 2000)

Figure 4 - Mean annual precipitation from 1940 to 2000 at Chemult, Oregon (NOAA, 2000)

Figure 5 - Mean monthly precipitation and snowfall from 1948 to 2000 at Crater Lake

National Park, Oregon (NOAA, 2000) 8

Figure 6 - Recent geologic mapping near the Klamath Marsh. Wocus Bay (Conaway and Cummings, in press), Soloman Butte (Lee and Cummings, in press), Military Crossing (Melady and Cummings unpublished mapping, 2000), and

Wildhorse Ridge quadrangles (Cummings et al., in review). 9

Figure 7 - Generalized stratigraphic units in the Military Crossing (Melady and

Cummings, in preparation), Wildhorse Ridge (Cummings et al., in review),

Wocus Bay (Conaway and Cummings, in press), and Soloman Butte (Lee and Cummings, in press) quadrangles 11

Figure 8 - Location of Wildhorse Ridge-Military Crossing (WRMC) fault zone 17

Figure 9 - Mean annual precipitation (cm) for the Williamson River basin, 1960-1990.

(Oregon Climate Service, 2001) 20

Figure 10 - Sub-regions in the Williamson River basin used for calculation of precipitation volume 21 
Figure 11 - Mean precipitation volume in the sub-regions around Klamath Marsh. .22

Figure 12 - Locations of evapotranspiration calculation sites. 24

Figure 13 - Location of hand-auger samples for air-fall material examination and location of gaging points on Sand Creek used for ash-flow infiltration examination. 34

Figure 14 - Grain size weight percent and water weight percent with depth for samples taken on 1-April-00 35

Figure 15 - Grain size weight percent and water weight percent with depth for samples taken on 30-April-00. 35

Figure 16 - Grain size weight percentage and water weight percent with depth for samples taken on 16-June-00. 36

Figure 17 - Grain size weight percent and water weight percent with depth from samples taken on 20-July-00. 36

Figure 18 - Grain size weight percent and water weight percent with depth from samples taken on 20-Jan-01

Figure 19 - Grain size weight percent and water weight percent with depth from samples taken on 27-April-01

Figure 20 - Location of areas used to describe geology with relative well log locations.

Well logs are located in Appendix B. Area 1 - Upper Williamson, Area 2 Skellock Upland, Area 3 - Sugarpine Mountain, Area 4 - Antelope Desert, Area 5 - Lower Williamson River. 
Figure 21 -Location of piezometers monitored by this study. Identification letters in green are keyed to piezometer measurements in Table 19.

Figure 22 - Discharge over the period of operation (5/1992 - 9/1995) of USGS gaging station \# 11492400 on Big Springs Creek (USGS, 2000) with measured monthly and mean monthly precipitation at Chiloquin (USDA, 2000). 62

Figure 23 - Gaging locations monitored by this study. Identification numbers in red are keyed to discharge Tables 21, 22, 23, 24 and water level Table 25 . 63

Figure 24 - Discharge on the Williamson River at Forest Service Bridge 9730 and USGS gaging station at Kirk. Discharge measured on the same day (USGS, 2000) .71

Figure 25 - Location of relative water surface elevation monitoring points 71

Figure 26 - Water Levels and Evapotranspiration in Klamath Marsh. Water levels are shown as a deviation from the original measurement on 3-June-00. .73

Figure 27 - Relative in and out flow at Klamath Marsh with evapotranspiration withdrawn from the discharge of the marsh. 76

Figure 28 - Location of isotope samples near Klamath Marsh. Numbers on map are keyed to Map ID column in Table 27. 78

Figure 29 - Deuterium and oxygen isotopes showing apparent split between sample location relative to WRMC Fault Zone. 80

Figure 30 - Evaporation trends in deuterium and oxygen isotopic ratios. Isotopic shifts indicated by arrow 82 
Figure 31 - Isotopic ratios around Klamath Marsh with evaporative trend in marsh water indicated by arrow.

Figure 32 - Conceptual model of ground and surface water flow paths near Klamath Marsh in May.

Figure 33 - Conceptual model of ground and surface water flow paths near Klamath Marsh in September. 


\section{Chapter 1 - Introduction}

The rain shadow effect, characterized by strong gradients in precipitation from topographically high to topographically low areas located in the downwind direction of mountain ranges, is a worldwide phenomenon. In many settings, the rain shadow effect develops in areas of active tectonism and volcanism. The management of sparse water resources in rain shadow-impacted areas is complicated by competing needs and interests.

The upper Klamath basin and the Williamson River sub-basin (Figure 1) lie in the rain shadow of the Cascade volcanic arc. Annual precipitation decreases from approximately $150 \mathrm{~cm} /$ year near the crest of the Cascades to $50 \mathrm{~cm} /$ year in lowland areas. Klamath Marsh is located in the Williamson River sub-basin where Pliocene and Pleistocene volcanic and sedimentary rocks are cut by normal faults, a result of Basin and Range extension. Use of water resources for agricultural irrigation south of Klamath Marsh has been impacted by endangered species designation of several endemic fish in Upper Klamath Lake (Figure 1) and dwindling Coho salmon populations in the Klamath River.

The rain shadow effect, mantling pumice deposits from the eruptions of Mount Mazama, as well as tectonism have created a unique hydrologic environment in the Williamson River basin. This study combines previous and recently acquired geologic data with hydrologic observations to examine the relationship between bedrock and ground and surface water movement near Klamath Marsh. Understanding how water is transmitted in the Williamson River basin has implications for future water resource planning. 

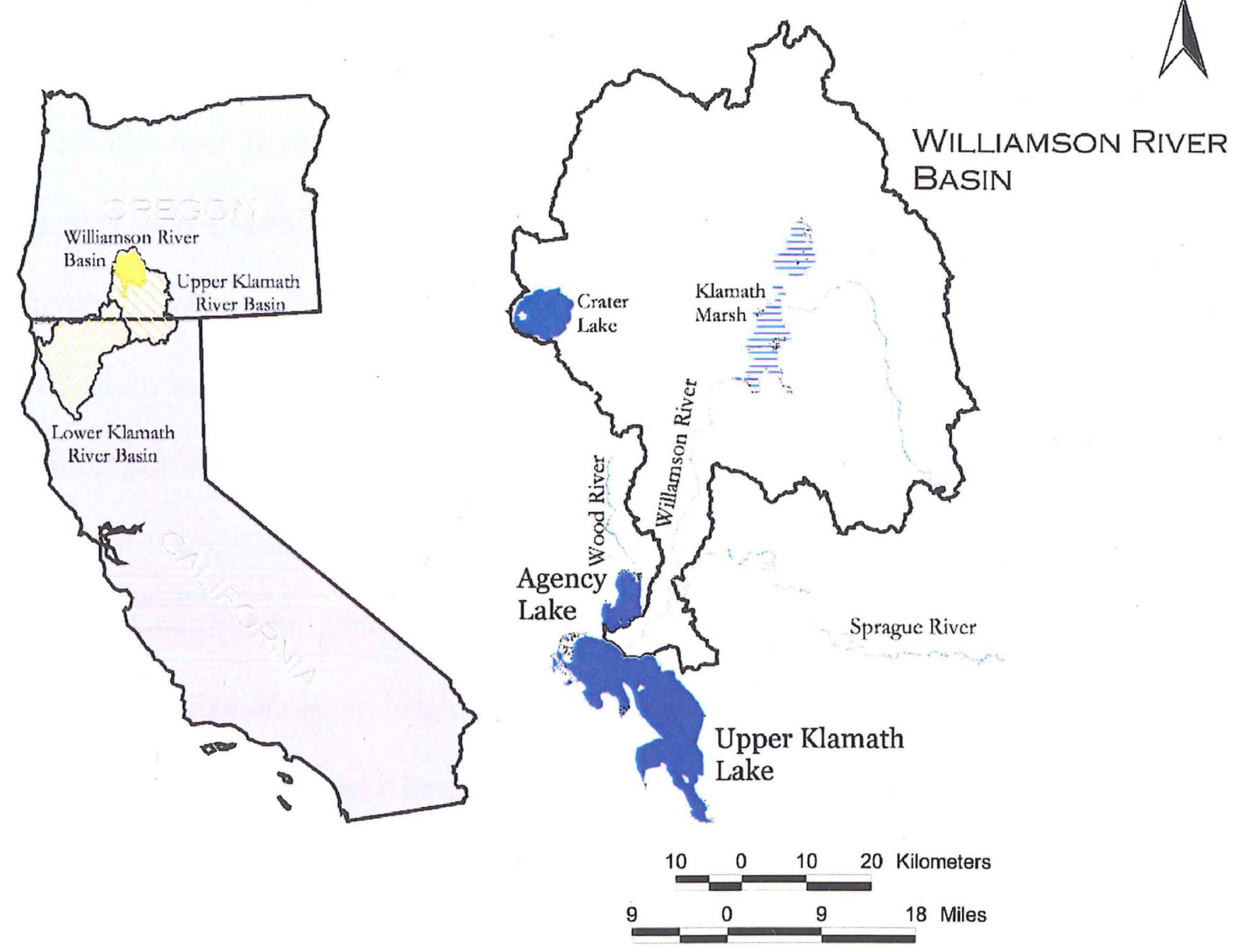

Figure 1 - General location map of features in the Williamson River basin.

\section{Background}

The upper Klamath River basin straddles the Oregon-California border, occupying $14,700 \mathrm{~km}^{2}$ in south central Oregon and $6,000 \mathrm{~km}^{2}$ in northern California (Figure 1). In Oregon, the basin is bounded physiographically to the west by the Cascade Range, to the north by the High Lava Plains, and to the east by the Basin and Range province. Normal faults resulting from north-northwest trending horst and grabens produced by Basin and Range extension (Peterson and McIntyre, 1970; Sherrod and Pickthorn, 1992) and volcanic centers dominate the topography in this part of the upper Klamath River basin. 
The Williamson River basin is the northernmost sub-basin in the upper Klamath River basin, occupying $5000 \mathrm{~km}^{2}$ (Winema National Forest, 1997). The Sprague, Wood, and Williamson Rivers (Figure 1) are the largest rivers in the upper Klamath River basin. The Williamson River, the largest of the three rivers in terms of discharge and length, flows north from its headwaters near Yamsay Mountain, eventually turning west, then south and flowing through the Klamath Marsh. South of the Klamath Marsh, the Williamson converges with the Sprague River and eventually discharges into Upper Klamath Lake. The Wood River flows south from Wood River Spring at the southwest extent of the Chemult Plateau into Agency Lake, which empties into Upper Klamath Lake. The Klamath River originates at the southern end of Upper Klamath Lake, winds through the Cascades and Klamath Mountains, and eventually discharges into the Pacific Ocean in northern California.

Upper Klamath Lake is the lake with the largest surface area in Oregon. The U.S. Bureau of Reclamation as part of its Klamath Project built a small dam at the southern end of Upper Klamath Lake to allow the elevation of the lake surface to be varied to facilitate water diversion (Adams and Cho, 1998). Since 1906, the Klamath Project has provided irrigation to approximately $890 \mathrm{~km}^{2}$ of farmland through nearly $300 \mathrm{~km}$ of irrigation channels in southern Oregon and northern California (U.S. Bureau of Reclamation, 1993). Irrigation water supplied by the Klamath Project supported gross agricultural crop and ranch sales in excess of \$130 million in Klamath County in 2000 (Oregon Department of Agriculture, 2001) 
Demands on in-stream flow for wildlife habitat as well as agricultural irrigation have made water resources particularly important in the Upper Klamath Basin. The Lost River sucker (Deltistes luxatus) and Short-nose sucker (Chasmites brevirostris) are endemic to Upper Klamath Lake and in-flowing streams. In 1998, the U.S. Fish and Wildlife Service listed the two suckers as endangered species (Saiki et al., 1999). To protect the habitat of these species, the U.S. Fish and Wildlife Service set monthly minimum lake levels in Upper Klamath Lake (Adams and Cho, 1998). If the lake drops below these minimum levels, diversion of water for irrigation is restricted. Historical lake levels indicate that water level restrictions would not have been met in 45 out of 73 years from 1922 through 1994 without water flow reduction in agricultural diversions (Adams and Cho, 1998)

The Klamath Marsh (Figure 2) is a large wetland complex $\left(350 \mathrm{~km}^{2}\right)$ centrally located in the Williamson River basin. In 1958, the Klamath Marsh National Wildlife Refuge was formed, encompassing over 40,000 acres $\left(162 \mathrm{~km}^{2}\right)$ in and around the Klamath Marsh. Klamath Marsh is one of six wildlife refuges in the Klamath River Basin which together support approximately 400 species of resident and migratory wildlife (U.S. Fish and Wildlife Service, 2002). Additionally, each year the refuges serve as migratory stopovers for roughly three-quarters of the Pacific Flyway waterfowl, with peak concentrations of over one million birds (U.S. Fish and Wildlife Service, 2002). 


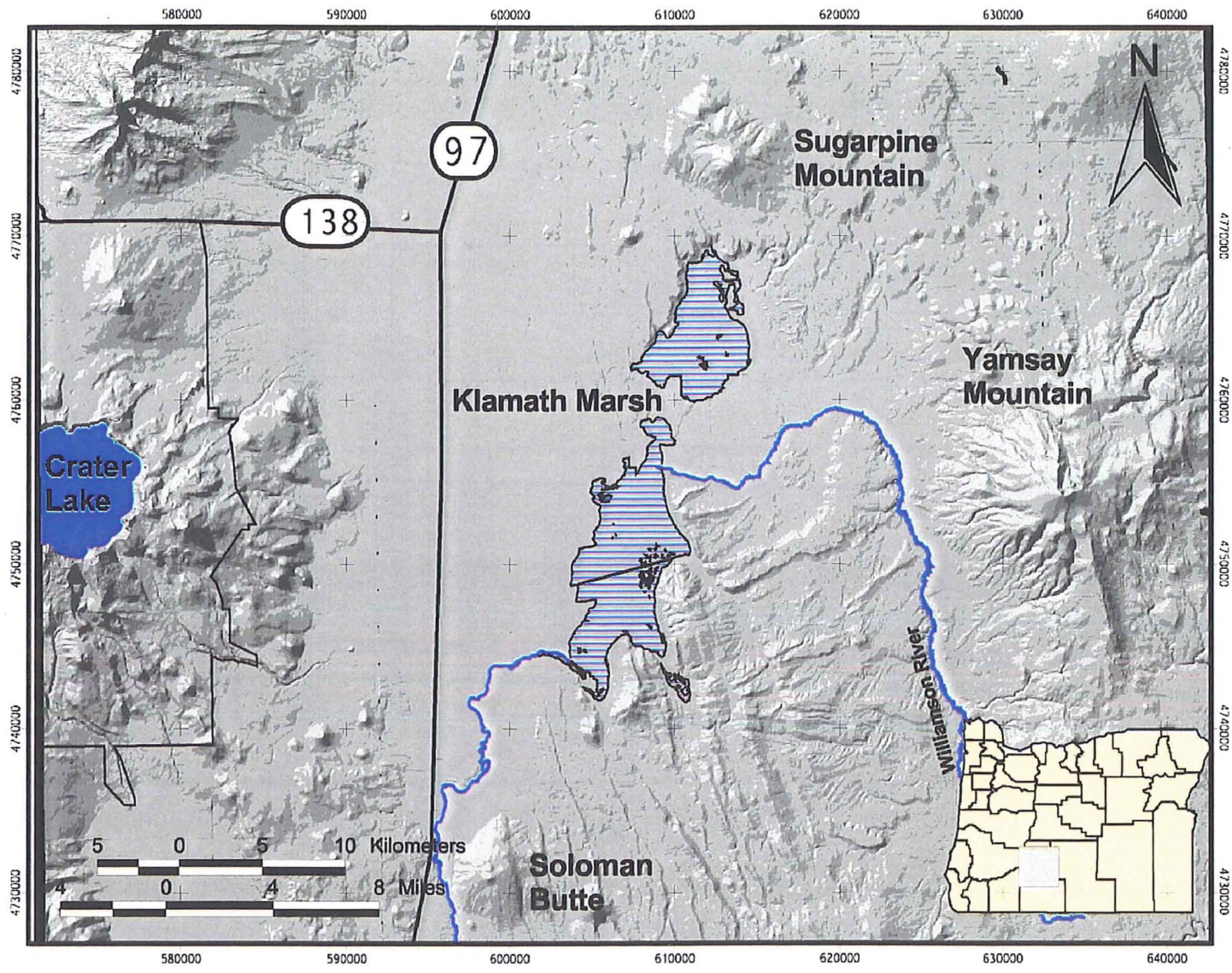

Figure 2 - Location of Klamath Marsh and vicinity.

\section{Climate}

The Klamath Marsh lies in the rain shadow of the Cascades and has a semi-arid winter rainfall climate (Leonard and Harris, 1974). A weather station maintained by the National Oceanic and Atmospheric Administration (NOAA) located in Chemult, Oregon, $32 \mathrm{~km}$ (20 miles) north of the Klamath Marsh at an elevation of $1450 \mathrm{~m}$ (4759 ft), allows an examination of historical (1940-2000) climatic information. 


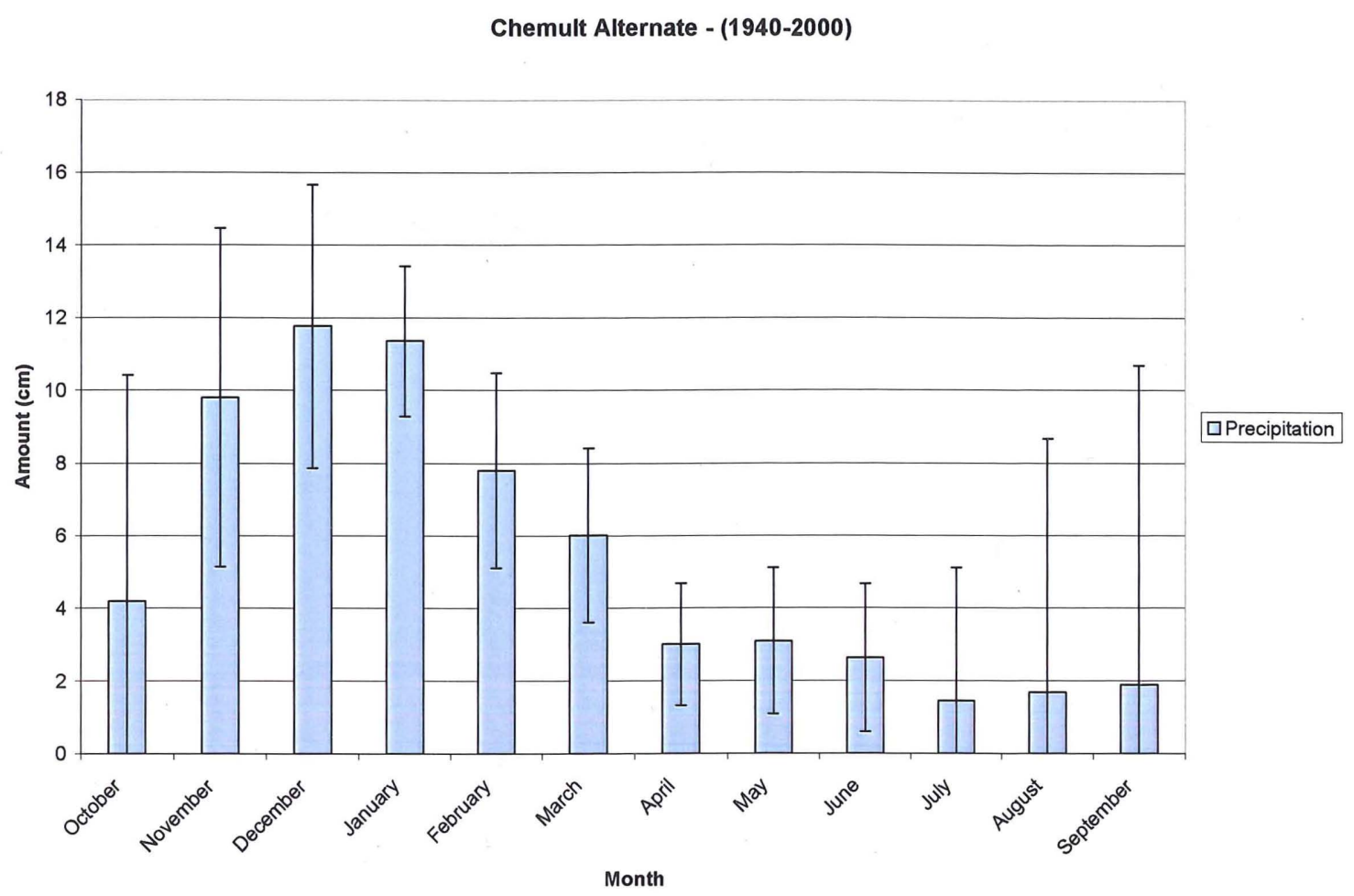

Figure 3 - Mean monthly precipitation from 1940-2000 at Chemult, Oregon (NOAA, 2000).

Mean annual temperature is $7^{\circ} \mathrm{C}\left(44^{\circ} \mathrm{F}\right)$, with extreme temperatures of $39^{\circ} \mathrm{C}$ $\left(102^{\circ} \mathrm{F}\right)$ in July of 1946 and $-34^{\circ} \mathrm{C}\left(-30^{\circ} \mathrm{F}\right)$ in January of 1943 and December of 1972.

Mean annual precipitation is $55.4, \sigma \pm 47.1 \mathrm{~cm}(21.8, \sigma \pm 18.6 \mathrm{in})$, with 79 percent received during the months of October through March and 21 percent received from April through September (Figure 3). The annual precipitation maximum (Figure 4) over this period occurred in 1996 with $91.3 \mathrm{~cm}$ (35.9 in) and the minimum occurred in 1985 with $32.0 \mathrm{~cm}(12.6 \mathrm{in})$. 


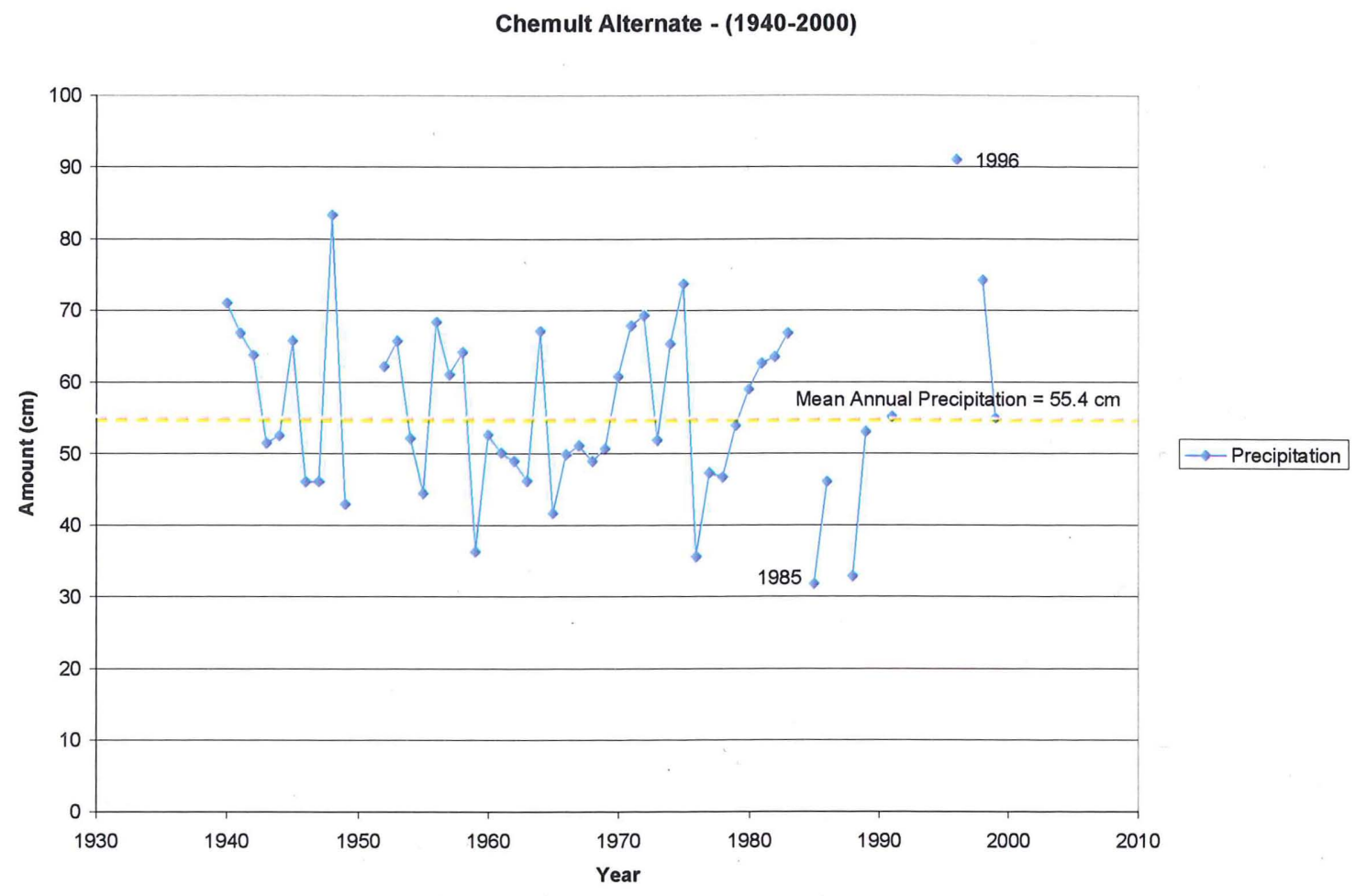

Figure 4 - Mean annual precipitation from 1940 to 2000 at Chemult, Oregon (NOAA, 2000).

The rain shadow effect induced by the Cascade crest can be seen by comparison of historical (1948-2000) climatic information from a NOAA weather station at Crater Lake National Park (Figure 5) with climatic data from Chemult. The Crater Lake weather station is located $32 \mathrm{~km}$ ( 20 miles) due west of the Klamath Marsh at an elevation of $1973 \mathrm{~m}$ (6473 ft) and approximately $45 \mathrm{~km}$ southwest of the Chemult Snotel site. Mean annual temperature is $4^{\circ} \mathrm{C}\left(38^{\circ} \mathrm{F}\right)$. Mean annual precipitation is $173.5, \sigma \pm 92.3 \mathrm{~cm}(68.3, \sigma \pm 36.4 \mathrm{in})$, with a mean annual snowfall amount of 1297.7, $\sigma \pm 923.4 \mathrm{~cm}(510.9, \sigma \pm 363.5 \mathrm{in})$. 


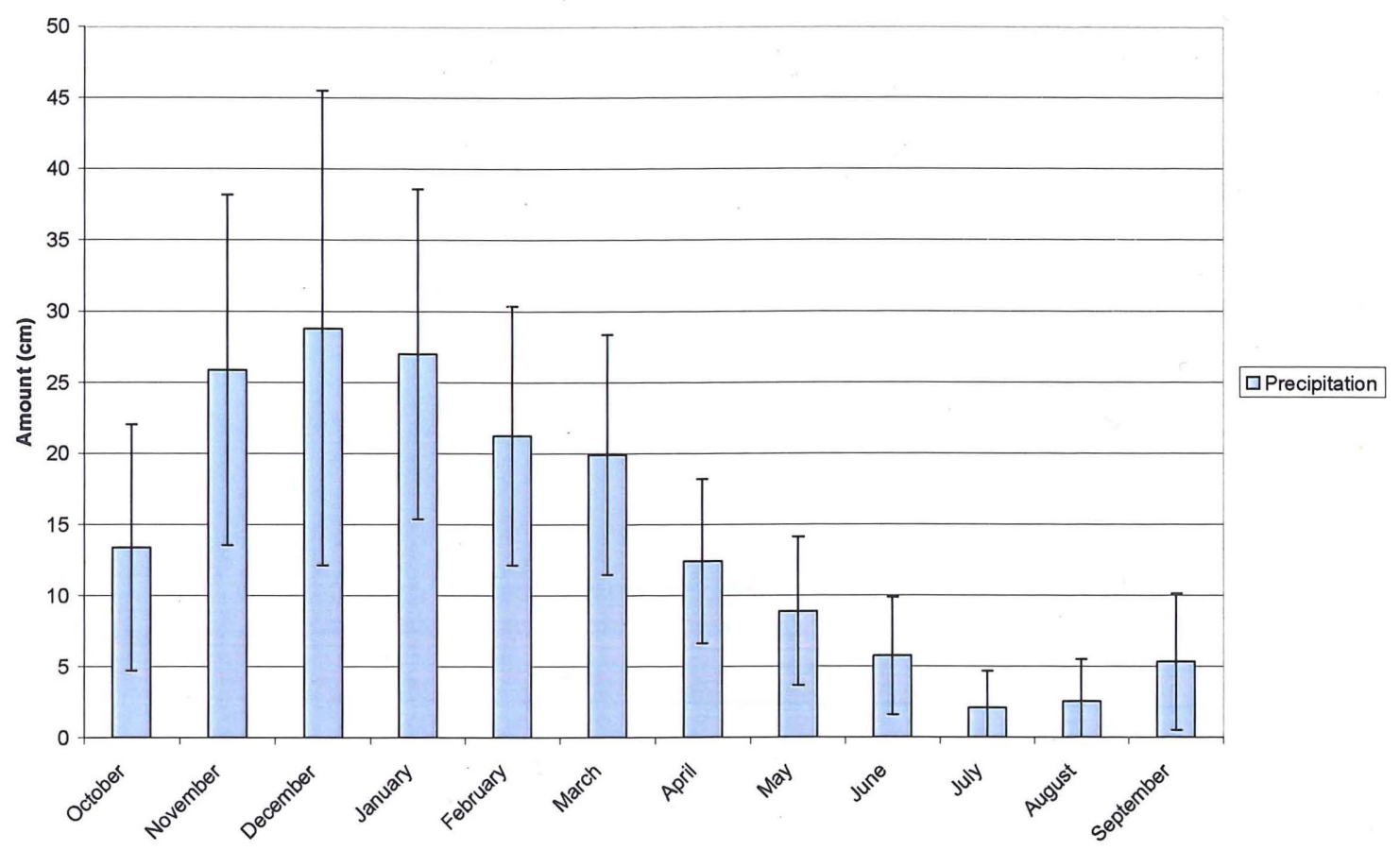

Figure 5 - Mean monthly precipitation and snowfall from 1948 to 2000 at Crater Lake National Park, Oregon (NOAA, 2000)

\section{Geology}

The geology of the Williamson River basin has been addressed in several smallscale geologic investigations and hydrogeologic reconnaissance studies. Peterson and McIntyre (1970) and Sherrod and Pickthorn (1992) characterized the basin to consist of Pliocene and Pleistocene basalt and basaltic andesite lava flows interbedded with fluviolacustrine volcaniclastic sedimentary rocks. Surficial deposits are dominated by pyroclastic material from the Holocene eruptions of Mount Mazama. Hering (1981) studied Yamsay Mountain (Figure 2), a composite volcano located east of the Klamath Marsh. Yamsay Mountain is described by Hering (1981) as a Pliocene calc-alkaline composite volcano, composed of alternating flows of basaltic andesite and dacite, 
interbedded with pyroclastic deposits. An intra-caldera dacite flow near the summit yielded an age date of $4.79 \pm 0.17 \mathrm{Ma}$ (McKee et al., 1976; Fiebelkorn et al., 1983).
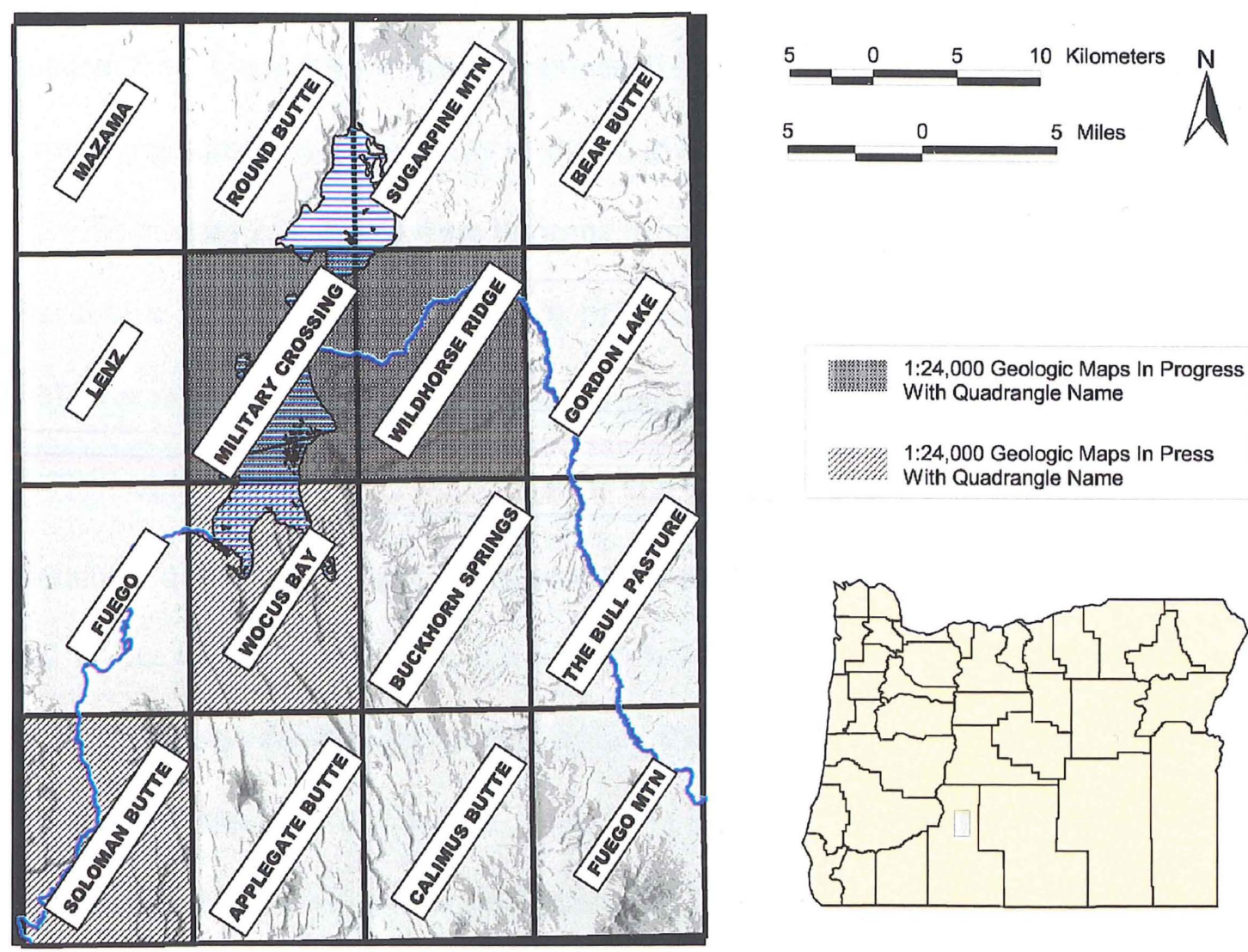
With Quadrangle Name 1:24,000 Geologic Maps In Press With Quadrangle Name

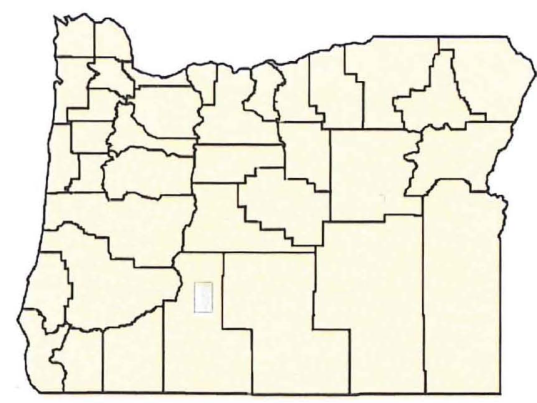

Figure 6 - Recent geologic mapping near the Klamath Marsh. Wocus Bay (Conaway and Cummings, in press), Soloman Butte (Lee and Cummings, in press), Military Crossing (Melady and Cummings unpublished mapping, 2000), and Wildhorse Ridge quadrangles (Cummings et al., in review).

Recent geologic mapping at 1:24,000 scale has been conducted by Portland State University. Four 7.5 minute quadrangles have been or are in the process of being mapped in the Williamson River basin (Figure 6). Conaway and Cummings (in press), Lee and Cummings (in press), Melady and Cummings (unpublished mapping, 2000) and Cummings et al. (in review) mapped the geology of the Wocus Bay, Soloman Butte, 
Military Crossing, and Wildhorse Ridge quadrangles, respectively. The volcanic rocks of these four quadrangles are divided into six sequences based on lithology, geochemistry, and geochronology by Lee (2000) in the Soloman Butte and Wocus Bay quadrangles. These subdivisions are extended into the Wildhorse Ridge and Military Crossing quadrangles in this study as shown in Figure 7.

Sequences 1, 2, 3, and 4 are Pliocene in age while sequences 5 and 6 are Pleistocene in age. Sequence 1 consists of interfingered alkali-rich and low-alkali suites with ages ranging from $3.68 \pm 0.08 \mathrm{Ma}$ (Wildhorse Ridge flow, Sherrod and Pickthorn, 1992) to at least $4.09 \pm 0.05 \mathrm{Ma}$ (Conaway and Cummings, in press). Units in this sequence comprise the ridges along the eastern margin of Klamath Marsh, Little Wocus and Wocus Buttes, and Wildhorse Ridge. In the Military Crossing, Wocus Bay, and Wildhorse Ridge quadrangles two pyroclastic flows are present in sequence 1 . The tuff of Skellock Draw (Cummings et al., in review), the most widespread of these two units, is a lithic-bearing, poorly welded rhyolitic tuff. This unit thins to the east and appears to have its source in the vicinity of Klamath Marsh. In outcrop, the tuff of Skellock Draw is highly indurated and in places may be partially welded (Melady and Cummings unpublished mapping, 2000). The tuff of Meadow Creek is also lithified and, in the Wildhorse Ridge quadrangle, is characterized by black trachyandesite pumice blocks up to $1 \mathrm{~m}$ in diameter (Cumings et al., in review). Thickness variability and size distribution of pumice blocks in this alkali-rich tuff suggest its source lies south toward the Sprague River valley. 


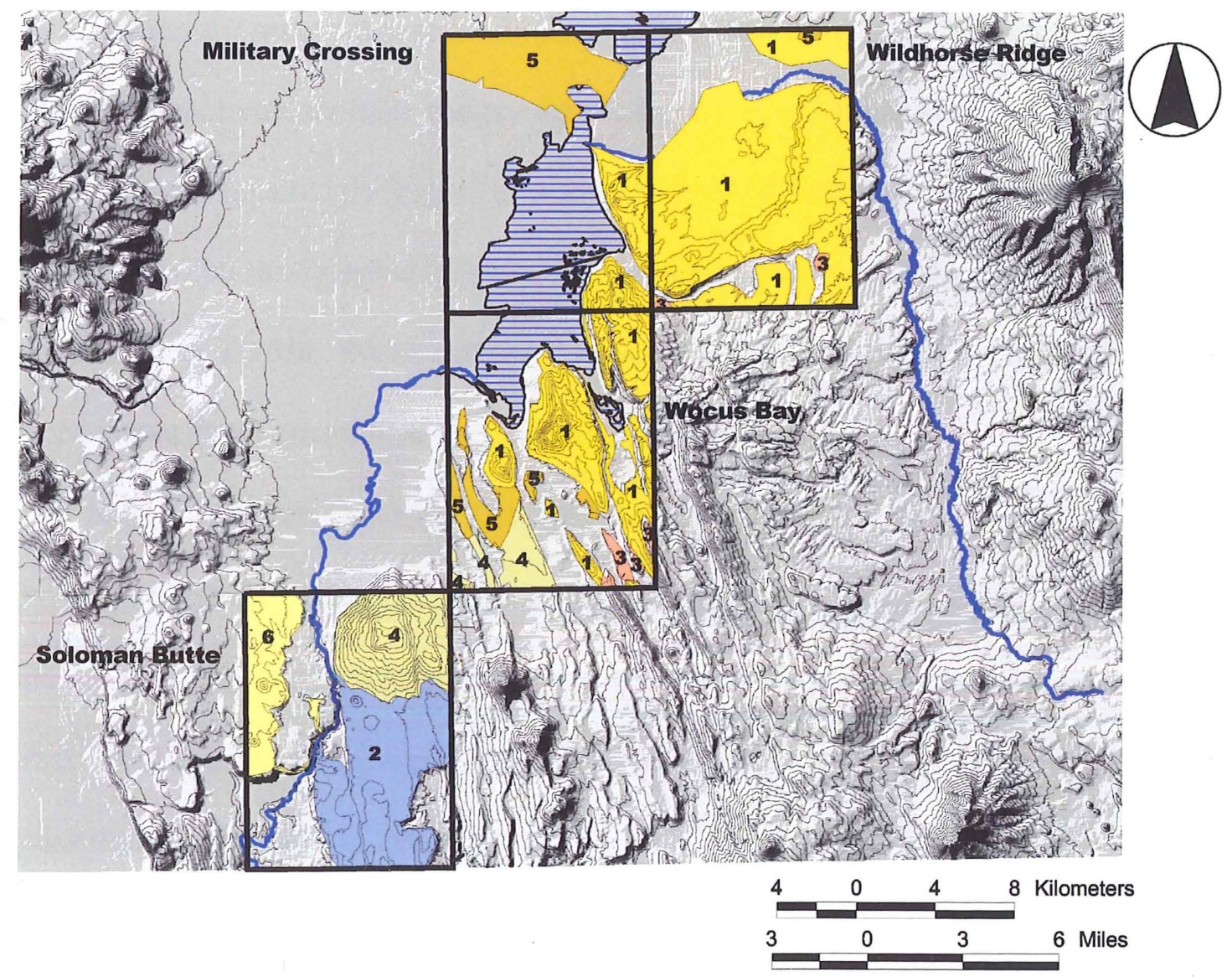

Figure 7 - Generalized stratigraphic units in the Military Crossing (Melady and Cummings, in preparation), Wildhorse Ridge (Cummings et al., in review), Wocus Bay (Conaway and Cummings, in press), and Soloman Butte (Lee and Cummings, in press) quadrangles. Sequence 1 includes $4.09 \pm 0.05$ to $3.68 \pm 0.08 \mathrm{Ma}$ trachybasalt to trachydacite lava flows and pyroclastic flow deposits, and basaltic andesite lavas. Sequence 2 includes approximately $3 \mathrm{Ma}$ low-potassium, high-alumina olivine tholeiite primitive basalt lavas. Sequence 3 contains rocks older than $2.05 \pm 0.12 \mathrm{Ma}$ and includes calc-alkaline basaltic andesite lavas. Sequence 4 includes $2.05 \pm 0.12 \mathrm{Ma}$ and younger calc-alkaline basaltic andesite and andesite lavas and andesitic vent deposits. Sequence 5 includes $1.62 \pm 0.47$ Ma calc-alkaline high alumina basalt lavas. Sequence 6 is $1.14 \pm 0.14 \mathrm{Ma}$ and younger calc-alkaline basaltic andesite, andesite, and trachyandesite lavas. Modified from Lee (2000). 
Sequence 2 units are described by Lee (2000) as late Pliocene low potassium, high-alumina olivine tholeiite and are exposed in the southeastern portion of the Soloman Butte quadrangle (Figure 6) where they underlie sequence 4 units at Soloman Butte. Based on stratigraphic relationships, sequence 2 units are believed to be approximately 3.0 Ma. Basalt tuff cones exposed in the Williamson River Canyon in the Soloman Butte quadrangle are included in sequence 2.

Sequence 3 units consist of late Pliocene basaltic andesite lava flows in the Wocus Bay quadrangle (Figure 6) and are believed to be between $2.05 \pm 0.12 \mathrm{Ma}$ (sequence 4) and 3.0 $\mathrm{Ma}$ (sequence 2) based on stratigraphic relationships (Lee and Cummings, in press; Conaway and Cummings, in press). This sequence is not widespread in the four quadrangles considered in this study.

Sequence 4 consists of Plio-Pleistocene andesite and minor basaltic andesite lava flows including the composite volcano of Soloman Butte. $\mathrm{An}{ }^{40} \mathrm{Ar} /{ }^{39} \mathrm{Ar}$ date of 2.05 \pm 0.12 obtaind from a flow interpreted by Conaway and Cummings (in press) to be one of the earliest flows from Soloman Butte indicates the lower bound on this sequence.

Sequence 5 consists of Plio-Pleistocene basalt flows that erupted from vents in the Wocus Bay quadrangle, the area northwest of Klamath Marsh known as the Peninsula (Figure 8) in the Military Crossing quadrangle, and possibly Sugarpine Mountain. A lava flow in the Wocus Bay quadrangle yielded an age of $1.62 \pm 0.47$ Ma (Conaway and Cummings, in press). In outcrop, these flows weather to boulders that are up to one meter in diameter and display a characteristic diktytaxitic $(20 \%$ 
cavities) texture (Conaway and Cummings, in press). Reconnaissance geologic information gathered by this study indicate that variably eroded shield volcanoes in the vicinity of Sugarpine Mountain consist of high alumina basalts that appear texturally similar to sequence 5 units.

Sequence 6 units are composed of multiple Pleistocene basaltic andesite, andesite, and trachyandesite lava flows in the northwest section of the Soloman Butte quadrangle and extend into neighboring quadrangles to the north and northwest. An ${ }^{40} \mathrm{Ar} /{ }^{39} \mathrm{Ar}$ age of $1.14 \pm 0.10 \mathrm{Ma}$ on a lava flow within sequence 6 indicates emplacement during the middle Pleistocene (Lee and Cummings, in press). A wellexposed sedimentary section on Highway 97 near Collier Memorial State Park is included in sequence 6. Biostratigraphy and tephrachronology suggest these sedimentary rocks are late Pliocene to Pleistocene (Lee, 2000).

Pyroclastic-flow and -fall deposits from the climactic eruption of Mount Mazama at 7,627 \pm 150 cal. Yr. B.P. (Zdanowicz et al., 1999) overlie all bedrock units. Driller's logs for water wells indicate thickness of these units range from 25 - 30 m near the foothills of the Cascades (Klam 51027, OWRD) to $1-5$ m east of the Klamath Marsh (Klam 683, OWRD). Within the marsh, the pumice deposits are overlain by approximately 1 to 2 meters of organic-rich, fine-grained sediment.

Several hydrogeologic investigations in the Klamath Basin have addressed the geology of the Williamson River basin. Newcomb and Hart (1958) examined regional geology in a groundwater resources investigation in the Klamath River basin. They describe volcanic rocks of the region in two main units: (1) basaltic lava flows and 
sedimentary series present over most of the Klamath basin, and (2) andesitic lava rock that lacks the sedimentary units. Leonard and Harris (1974) examined groundwater near Klamath Marsh, as well as in the Sprague River, Swan Lake, Yonna, Poe, and Langell valleys and described the geology of the basin in a broad sense. The oldest rocks exposed or reached by water wells are Pliocene basalt flows. In outcrop, the basalt flows are interbedded with tuff and scoriacous flow breccia. The basalt is vesicular, displays columnar jointing, and contains abundant phenocrysts of olivine. Individual flows range from a meter to at least 10 meters in thickness, with the unit ranging from 90 meters to 240 meters thick near Klamath Falls (Newcomb and Hart, 1958). Drillers' logs from water wells in the region describe the flows as hard and blue, black, red, or brown. Interflow zones are called "cinders" or sometimes "burnt lava" or "black sand." These basalt flows are overlain by Pliocene volcaniclastic sediment, which is overlain by Pliocene and Pleistocene andesitic and basaltic flows, which are overlain by pyroclastic-fall and -flow deposits from Mount Mazama.

Newcomb and Hart (1958) indicate the presence of a large aquifer underlying the pumice plain northwest of Klamath Marsh. They indicate groundwater in this aquifer moves on a broad front toward the marsh at a gradient of $0.38 \mathrm{~m} \mathrm{~km}^{-1}$. They also examine the relationship between discharge at Big Springs Creek (UTM: 600100 E, 4757650 N), discharge at Spring Creek (UTM: 591000 E, 4725100 N), and precipitation. It is indicated that after several years of below average precipitation, flow at Big Springs Creek ceases and they postulate that Spring Creek flows at a reduced rate. They also indicate that Big Springs at the head of Big Springs Creek is apparently 
an overflow point of the groundwater in the underlying aquifer. Leonard and Harris (1974) also examined aquifers in the basin and described their water-bearing properties. They similarly indicate groundwater in the deposits northwest of Klamath Marsh flowing in the general direction of the marsh.

Conaway (2000) and Conaway and Cummings (in press) discuss the paleohydrogeology of Klamath Marsh. They indicate that late in the climactic eruption of Mount Mazama, pyroclastic flows moved down the eastern flank of Mount Mazama forming the gently sloping surface now known as the Antelope Desert. Some of the flows moved south and were trapped in the canyon in which the Williamson River currently flows, forming a dam. Water backed up behind this dam to an elevation of $1402 \mathrm{~m}$, before catastrophically draining. Pyroclastic-fall, -flow deposits, and Pleistocene sand dune deposits around the marsh below $1402 \mathrm{~m}$ were reworked by wave action within the lake (Cummings et al., in review).

\section{Structure}

The Williamson River basin is located at the northwesternmost extent of the basin and range province and is characterized by north and northwest-striking normal faults generally dipping $50^{\circ}$ to $60^{\circ}$ with displacements mostly less than $100 \mathrm{~m}$ (Sherrod and Pickthorn, 1992). The Klamath Marsh is located in the Chemult graben which is in the Cascade regional neotectonic zone defined by Pezzopane and Weldon (1993).

Pleistocene and younger units are offset by normal faults in the Klamath, Chemult, and La Pine grabens within this zone. The vertical slip rate for the West Klamath Lake fault zone, south of the western edge of the Klamath graben, is estimated at $0.3 \mathrm{~mm} \mathrm{yr}^{-1}$ by 
Bacon et al. (1999). Locally, Conaway and Cummings (in press) and Lee and Cummings (in press) characterize the structure directly south of Klamath Marsh as north-northwest striking, high-angle normal faults with displacement ranging from $15 \mathrm{~m}$ to $130 \mathrm{~m}$ with dips at approximately $70^{\circ}$. They also note the faulting is right and left overstepping (or en echelon) with ramp structures between steps in which the displacement of one fault decreases to zero while the displacement on the neighboring fault increases from zero.

Geologic mapping by Melady and Cummings (unpublished mapping, 2000) in the Military Crossing quadrangle indicates several normal faults along the eastern margin of the Klamath Marsh. This fault zone, the Wildhorse Ridge-Military Crossing (WRMC) fault zone (Cummings and Melady, 2002) (Figure 8), splits the Williamson River basin into two distinctly different hydrogeologic regimes. To the east of the fault zone lie rocks of Pliocene age (Cummings et al., in review) and to the west of the fault zone lie rocks of Pleistocene age (Melady and Cummings unpublished mapping, 2000). The sense of motion on the fault zone is down-to-thewest and it strikes north-northwest. Overstepping of the fault zone may occur over an area referred to as The Peninsula (Figure 8), where the strike of the fault zone appears to change to become more north-south. North of the peninsula, the strike of the fault zone is north-northwest on the western edge of a prominent fault scarp located southwest of Sugarpine Mountain (Figure 2) and cutting basalt flows. Displacement on the fault zone is estimated by Cummings and Melady (2002) at $140 \mathrm{~m}$ based on 
correlation of lava flows in a water well driller's log and porphyritic basalt that outcrops near the base of Wildhorse Ridge (Figure 8).

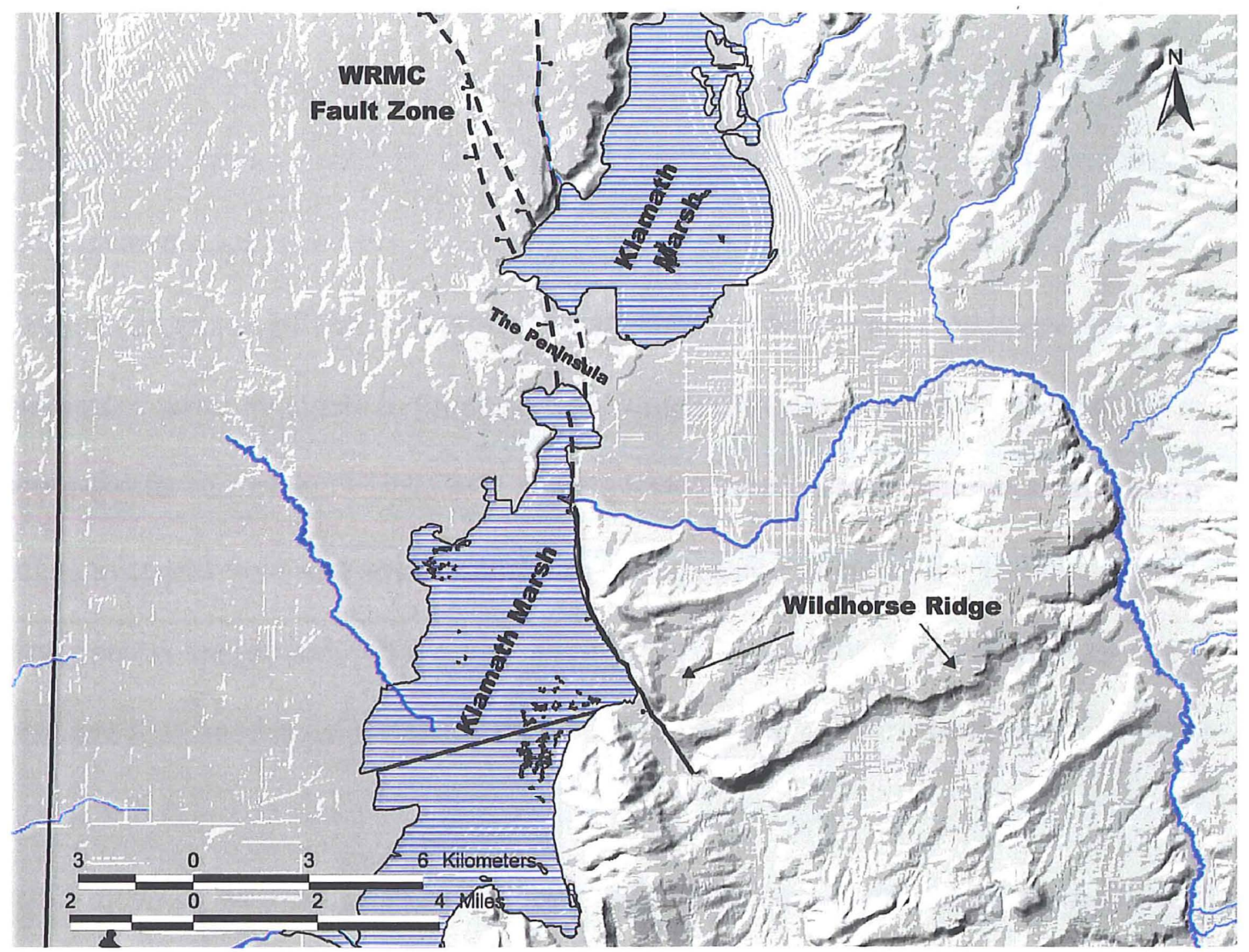

Figure 8 - Location of Wildhorse Ridge-Military Crossing (WRMC) fault zone

Two fault scarps in the WRMC fault zone near Klamath Marsh displace Mount Mazama pyroclastic deposits, indicating movement younger than 7,627 $\pm 150 \mathrm{cal}$. Yr. B.P. (Zdanowicz et al., 1999). The easternmost and older of the two scarps has a strike length of approximately $4.5 \mathrm{~km}$, with a displacement of $7 \mathrm{~m}$. The younger, westernmost scarp has a strike length of approximately $9 \mathrm{~km}$, with a displacement of $5 \mathrm{~m}$ (Cummings and Melady, 2002). 


\section{Chapter 2 - Hydrogeology}

\section{Introd uction}

Several factors influence the movement of ground and surface water in a watershed. Rock properties exert control on water movement as a function of hydraulic conductivity, demonstrated by fracture flow (secondary permeability) or intermatrix flow (primary permeability). Recharge, or precipitation, controls the amount of water that is available as surface and groundwater. In groundwater flow, recharge controls the amount of water available to produce head, which provides a necessary element for groundwater movement. Once water enters a watershed as precipitation, it either runs off as overland flow into streams and rivers, evaporates, or enters the ground. Once water enters the ground, it travels by way of gravity (unconfined aquifer) and/or pressure (confined aquifer) toward areas of discharge, eventually discharging into the ocean or leaking into an adjacent watershed as groundwater, or it is removed from the basin by water well withdrawal or evapotranspiration. Evapotranspiration can be loosely defined as the transfer of water from the Earth's surface to the atmosphere and is of foremost importance in water resource planning in some regions (Jensen et al., 1990).

The hydrogeology of the Williamson River basin near Klamath Marsh was examined by synthesis of precipitation and evapotranspiration data, previous and recently acquired geologic information, discharge measurements for major surface water streams and rivers, near surface aquifer water level data in several small basins near the marsh, and stable isotope data from several springs and streams entering Klamath Marsh and the Williamson River. These data provide necessary information to examine 
surface water - groundwater interaction, probable groundwater flow paths, and preliminary water budget estimations.

\section{Precipitation and Evapotranspiration}

Precipitation in the Williamson River sub-basin varies spatially as a result of the rain shadow effect produced by the Cascade Range. Because of this, lowlands in the basin receive much lower precipitation than upland regions. In this section I examine the distribution of precipitation across the Williamson River sub-basin and estimate annual volume of precipitation in potential areas of recharge. Additionally, meteorological data are used to estimate evapotranspiration near Klamath Marsh. Annual volume of evapotranspiration is generated and volume of recharge is estimated. Precipitation

The rain shadow effect of the Cascades is a dominant feature of the Williamson River basin. Mean annual precipitation (Figure 9) varies by $\sim 100 \mathrm{~cm}$ from the West to the central portion of the basin. Based on the precipitation distribution shown in Figure 9, ground and surface water recharge areas are expected along the western edge of the basin, the Cascades, and areas of elevated topography to the north (Sugarpine Mountain) and east (Yamsay Mountain) of Klamath Marsh.

Figure 9 shows precipitation distribution across the Williamson River basin from 1960-1990 based on Parameter-elevation Regressions on Independent Slopes Model (PRISM) developed by the Spatial Climate Analysis Service at Oregon State University and the Oregon Climate Service. This model incorporates digital elevation data to interpolate precipitation between measured precipitation at weather station arrays 
maintained by the National Weather Service and Natural Resources Conservation Service. Precipitation is interpolated in $4 \mathrm{~km}$ grids, with precipitation values in each grid cell an average over the entire area of that cell.

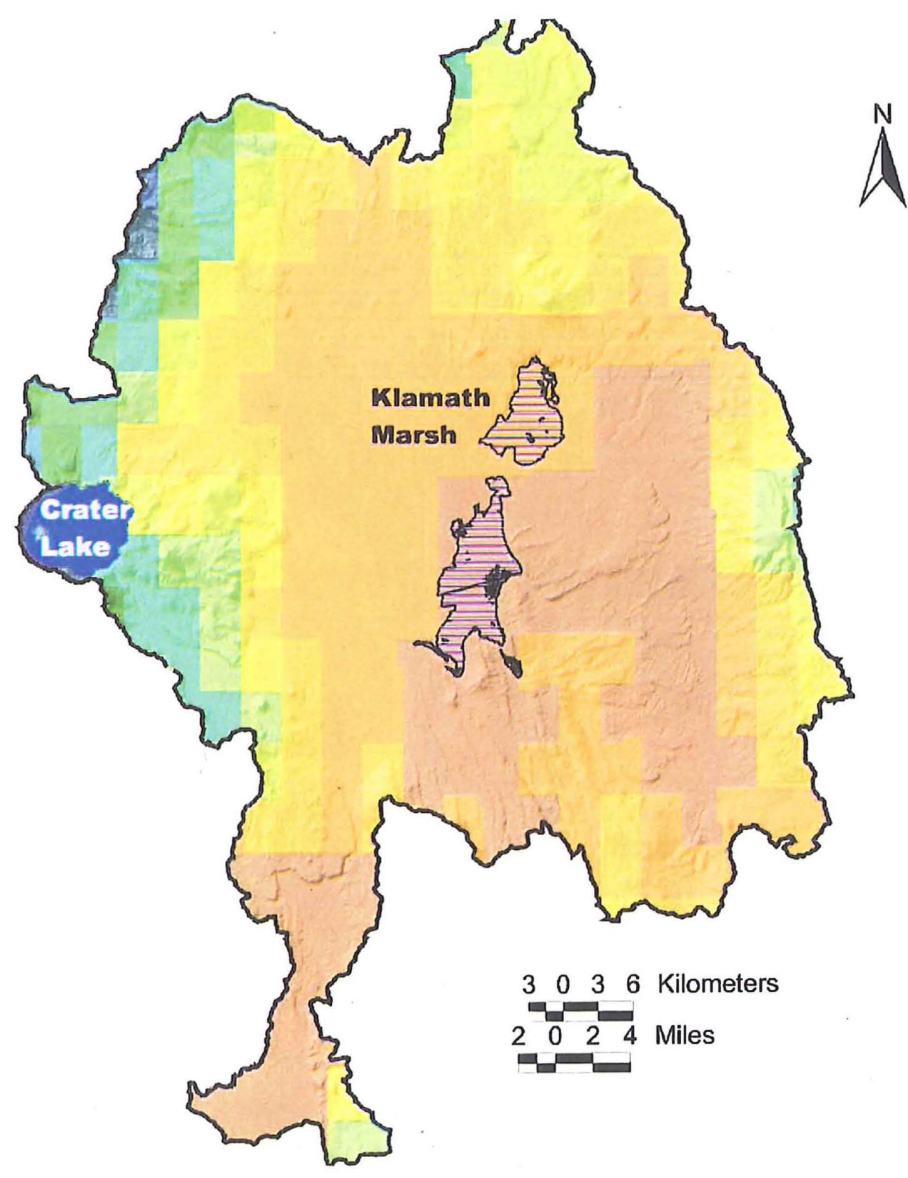

Mean Precipitation $40-45$ $45-50$ $50-55$ $55-60$ $60-65$ $65-70$ $70-75$ $75-80$ $80-85$ 85 - 90 $90-95$ 95 - 100 $100-105$ $105-110$ $110-115$ $115-120$ $120-125$ $125-130$ $130-135$ $135-140$ $140-145$ $145-150$ 150 - 155 $155-160$ $160-165$ $165-170$ $170-175$ 175 - 180 No Data

Figure 9 - Mean annual precipitation (cm) for the Williamson River basin, 1960-1990. (Oregon Climate Service, 2001)

An analysis of the spatial distribution of precipitation (Figure 9) across the Williamson River basin was performed to examine the volume of precipitation available for recharge in several areas within the basin. The basin was divided into sub-regions (Figure 10) on the basis of geology, landforms and elevation, faulting, and recharge 
potential. The division of the basin into sub-regions allows areas of relatively high precipitation to be distinguished from areas of relatively low precipitation. These geographic divisions will be followed throughout the rest of this document to present and summarize attributes in the basin.
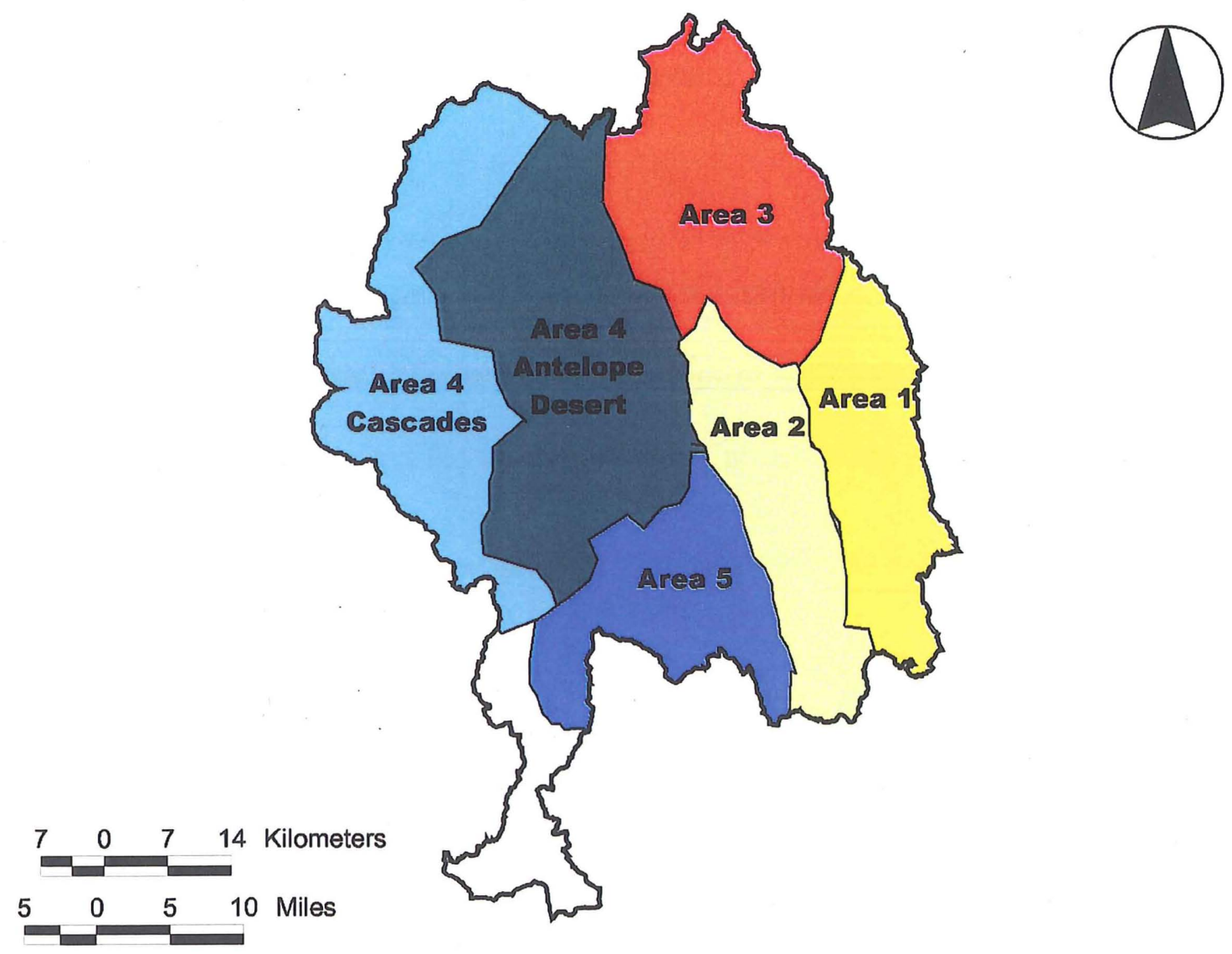

Figure 10 - Sub-regions in the Williamson River basin used for calculation of precipitation volume.

The area of each individual sub-region was multiplied by the precipitation distribution over the sub-region using Spatial Analyst functions in ESRI Arcview to calculate a mean volume of precipitation for each sub-region (Table 1 and Figure 11). 
Table 1 - Mean volume of precipitation, area, and spatially averaged precipitation in sub-areas.

\begin{tabular}{cccccccc}
\hline & Area 1 & Area 2 & Area 3 & $\begin{array}{c}\text { Area 4 - } \\
\text { Antelope } \\
\text { Desert }\end{array}$ & $\begin{array}{c}\text { Area 4- } \\
\text { Cascades }\end{array}$ & Area 5 & Total \\
\hline \hline $\begin{array}{c}\text { Preciptation } \\
\text { Volume }\left(\mathrm{m}^{3}\right)\end{array}$ & $3.62 \times 10^{8}$ & $2.16 \times 10^{8}$ & $4.89 \times 10^{8}$ & $5.91 \times 10^{8}$ & $8.31 \times 10^{8}$ & $2.57 \times 10^{8}$ & $2.75 \times 10^{9}$ \\
$\begin{array}{c}\text { Area of } \\
\text { Region }\left(\mathrm{m}^{2}\right)\end{array}$ & $5.45 \times 10^{8}$ & $4.09 \times 10^{8}$ & $6.81 \times 10^{8}$ & $1.06 \times 10^{9}$ & $7.71 \times 10^{8}$ & $4.64 \times 10^{8}$ & \\
$\begin{array}{c}\text { Mean } \\
\begin{array}{c}\text { Precipitation } \\
\text { in Area }(\mathrm{cm})\end{array}\end{array}$ & 66.5 & 52.9 & 71.8 & 55.7 & 107.8 & 55.4 & \\
\hline
\end{tabular}

Area 4 - Cascades receives the largest volume of precipitation $\left(831\right.$ million $\mathrm{m}^{3}$ ) because of its location along the crest and east slope of the Cascades. Area 2 located near Klamath Marsh receives the lowest volume of precipitation (216 million $\mathrm{m}^{3}$ ).

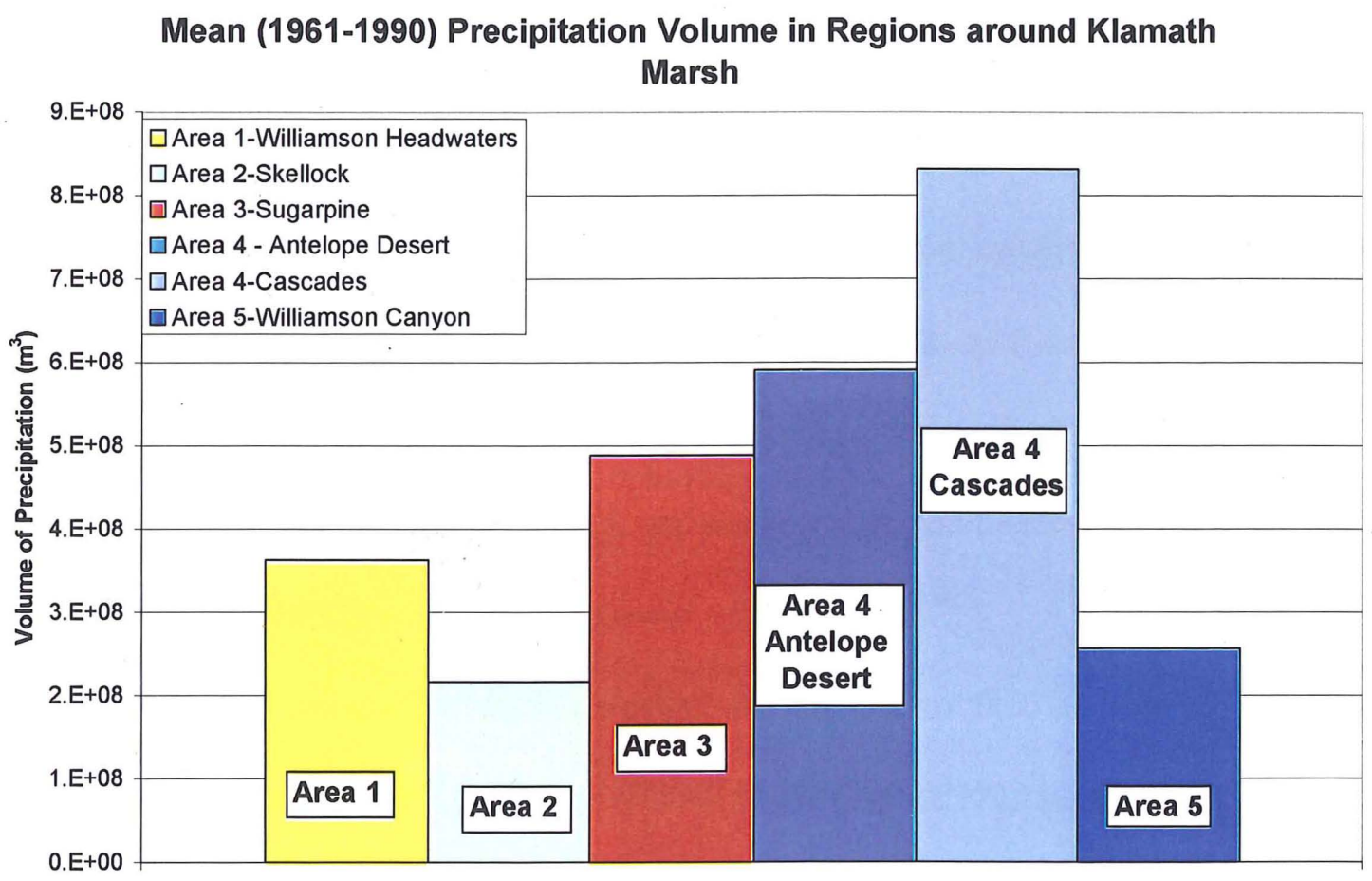

Figure 11 - Mean precipitation volume in the sub-regions around Klamath Marsh. 


\section{Evapotranspiration}

Evapotranspiration or consumptive use of water is the combined processes by which water is transferred from the earth's surface to the atmosphere. Processes include evaporation of water from the soil surface, interception by plants, and transpiration by plants.

\section{Calculation of Evapotranspiration}

Snyder and Pruitt (1992), based on the work of Pruitt and Doorenbos (1977), Jensen et al. (1990), and Dong et al. (1992), suggest use of a modified Penman equation (Equations 1, 2, 3, Appendix A) for the calculation of daily reference evapotranspiration $\left(\mathrm{ET}_{0}\right)$ for a grass reference using hourly weather station data. Reference evapotranspiration is defined by Dong et. al. (1992) as evapotranspiration that occurs over a full, uniform cover of healthy, well-watered, nonstressed, cool-season grass at uniform height between $0.10 \mathrm{~m}$ and $0.15 \mathrm{~m}$. Jensen et al. (1990) explain that the use of reference evapotranspiration and associated crop coefficients is a practical technique because it provides a conservative means of estimating crop evapotranspiration at progressive stages of growth. The equations used for calculation of evapotranspiration for this study are presented in appendix A and are based on parameters specified by Snyder and Pruitt (1992).

A Davis Instruments Groweather weather station was installed on June 13, 2000 and operated until October 21, 2000 in Skellock Draw (Figure 12), (section 7, T. 31 S., R. 10 E.; UTM 616994 E 4750024 N) measuring hourly values for air temperature, precipitation, wind speed, relative humidity, barometric pressure, and solar radiation so 
that evapotranspiration could be calculated. These data were then input into the equations presented in appendix A to generate reference evapotranspiration.

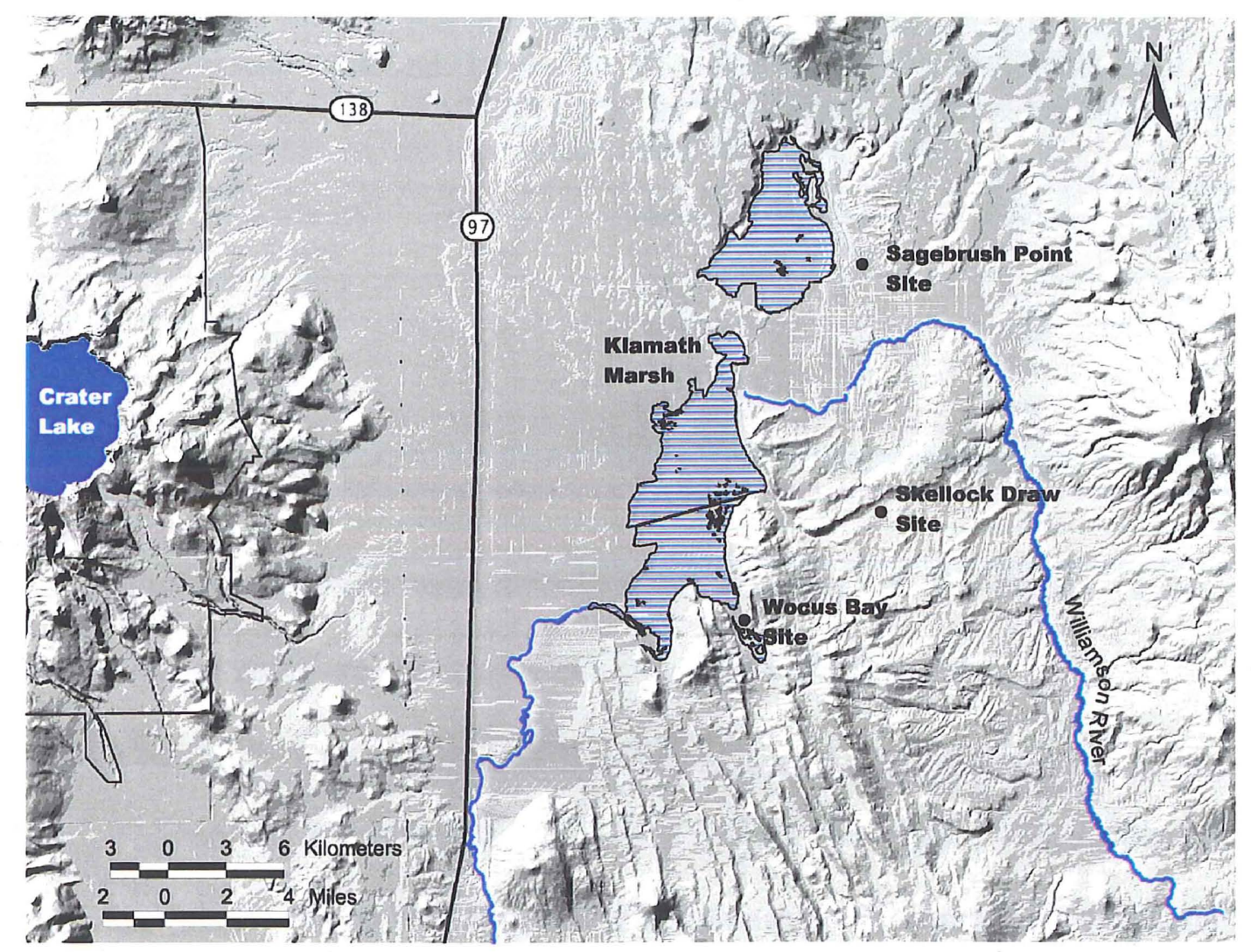

Figure 12 - Locations of evapotranspiration calculation sites

Evapotranspiration at nearby sites (Figure 12) is estimated by Bidlake (1997) and Bidlake and Payne (1998) for May - October 1996 and 1997. Bidlake (1997) used an empirical model based on the Priestley-Taylor equation to simulate daily mean growingseason evapotranspiration on the basis of daily minimum and maximum air temperature. This technique was used to estimate the monthly average of daily evapotranspiration at Sagebrush Point (Table 2) and Wocus Bay (Table 2), approximately $14 \mathrm{~km}$ and $10 \mathrm{~km}$ from the Skellock Draw site, respectively (Figure 12). Bidlake and Payne (1998) used 
the same technique to estimate monthly average of daily evapotranspiration at Wocus Bay (Table 2) from May through October in 1997.

Table 2 - Monthly average of daily evapotranspiration in millimeters per day at Sagebrush Point and Wocus Bay from Bidlake (1997), and Bidlake and Payne (1998), and Skellock Draw from this study. (N.C. = not calculated, instrumentation was not installed until mid-June, 2000)

\begin{tabular}{ccccccc}
\hline $\begin{array}{c}\text { Month } \\
(\mathbf{1 9 9 6 )}\end{array}$ & $\begin{array}{c}\text { Sagebrush } \\
\text { Point }\end{array}$ & $\begin{array}{c}\text { Wocus } \\
\text { Bay }\end{array}$ & $\begin{array}{c}\text { Month } \\
\mathbf{( 1 9 9 7 )}\end{array}$ & $\begin{array}{c}\text { Wocus } \\
\text { Bay }\end{array}$ & $\begin{array}{c}\text { Month } \\
(\mathbf{2 0 0 0 )}\end{array}$ & $\begin{array}{c}\text { Skellock } \\
\text { Draw }\end{array}$ \\
\hline \hline May & 3.1 & 4.0 & May & 6.6 & May & N.C. \\
June & 4.8 & 5.9 & June & 6.6 & June & 5.7 \\
July & 5.7 & 5.7 & July & 6.6 & July & 4.8 \\
August & 5.0 & 4.0 & August & 5.9 & August & 4.7 \\
September & 2.8 & 1.8 & September & 3.1 & September & 3.1 \\
October & 1.2 & 0.6 & October & 0.9 & October & 1.9 \\
\hline Total & $69.3 \mathrm{~cm}$ & $67.4 \mathrm{~cm}$ & & $91.1 \mathrm{~cm}$ & & $52.1 \mathrm{~cm}$
\end{tabular}

Comparison between values calculated by Bidlake (1997), Bidlake and Payne (1998), and this study are done cautiously. First, the method by which evapotranspiration was calculated differed, with this study using a modified Penman equation (Appendix A) and Bidlake (1997) and Bidlake and Payne (1998) studies using a modified Pristley-Taylor equation based on minimum and maximum air temperature. Second, evapotranspiration for this study is a reference evapotranspiration described by Dong et al. (1992), whereas Bidlake (1997), and Bidlake and Payne (1998) calculate evapotranspiration based on surfaces that either are saturated or are occupied with wellwatered and actively growing non-specific vegetation. Finally, evapotranspiration values in this study represent Skellock Draw during a portion (mid-June through lateOctober) of the summer growing season of 2000, with Bidlake (1997) representing Sagebrush Point and Wocus Bay in 1996, and Bidlake and Payne (1998) representing Wocus Bay in 1997 from May through October. When the common months (July September) among the studies are compared, the difference between the highest (1997, 
Wocus Bay $-48.1 \mathrm{~cm})$ and the lowest $(1996$, Wocus Bay $-35.5 \mathrm{~cm})$ amount of evapotranspiration is $12.6 \mathrm{~cm}$. Comparison of average temperature from May-October at Chemult, Oregon during 1996, 1997, and 2000 indicates that air temperature was lowest in $2000\left(10.8^{\circ} \mathrm{C}\right)$ and the highest in $1997\left(11.2^{\circ} \mathrm{C}\right)$. Average temperature at Chemult from $1948-2001$ was $11.6^{\circ} \mathrm{C}$, which is $0.8^{\circ} \mathrm{C}(2000)$ to $0.4^{\circ} \mathrm{C}$ (1997) higher than average temperature during the three studies. This may indicate that evapotranspiration during 1996, 1997, 2000 are below average due to the relationship between temperature and evapotranspiration.

\section{Recharge}

Evapotranspiration removes precipitation from the basin before it can infiltrate and recharge aquifers. In order to evaluate the volume of water that reaches aquifers in the Williamson River basin, evapotranspiration must be removed from precipitation. This was accomplished by multiplying the evapotranspiration calculated from this study $(52.1 \mathrm{~cm})$, Bidlake $(1997)(69.3 \mathrm{~cm}$ and $67.4 \mathrm{~cm}$, Average $=68.4 \mathrm{~cm})$, and Bidlake and Payne (1998) $(91.1 \mathrm{~cm})$ by the area of each sub-region, resulting in a volume of evapotranspiration for each sub-region. The calculated evapotranspiration values in this study are potential evapotranspiration, not actual evapotranspiration

Potential evapotranspiration and actual evapotranspiration are equivalent if the moisture conditions of the ground surface are similar to the well-watered, moist reference crop. If water is not available, actual evapotranspiration is less than potential evapotranspiration. Based on water content in pyroclastic-fall deposits discussed in the next section (Figures 14 - 19) and observation of a deep rooting zone noted in pines, it 
appears that vegetation is well-watered throughout most of the year. Because of this, potential and actual evapotranspiration for the purpose of this evaluation are assumed to be equal.

The elevation at the Skellock Draw site is approximately $1396 \mathrm{~m}$. However, elevation across the basin ranges from over $2440 \mathrm{~m}$ in the Cascades to $1375 \mathrm{~m}$ in Klamath Marsh. Variation of evapotranspiration with elevation was evaluated by comparison of evapotranspiration at Diamond Lake (elevation $1620 \mathrm{~m}$ ) and the Skellock Draw site over a 24 -hour period. This was done by inputting bi-hourly temperature data from a NOAA weather station located at Diamond Lake into the equations (Appendix A) used to calculate evapotranspiration at Skellock Draw. Evapotranspiration at the Skellock Draw site was $0.04 \mathrm{~mm}$ or approximately $3 \%$ higher than the evapotranspiration calculated at Diamond Lake for the 24-hour period (Table 3).

In addition to temperature, several other meteorological parameters that vary with elevation effect evapotranspiration. Limited data from the Diamond Lake weather station prevents similar evaluation of additional meteorological parameters. As a result, sensitivity of the equations used to calculate evapotranspiration were analyzed by altering temperature, wind speed, humidity, barometric pressure, and solar radiation by $50 \%$ and examination of the resulting change in evapotranspiration (Table 4). The highest change (42\%) in evapotranspiration resulted from altering solar radiation by $50 \%$ and the lowest change (3\%) resulted from altering wind speed by $50 \%$. Change in temperature by $50 \%$ resulted in evapotranspiration changing by $19 \%$ and changing barometric pressure resulted in an $8 \%$ change in evapotranspiration. Variation in these 
Table 3 - Temperature and evapotranspiration difference between Skellock Draw and Diamond Lake on 16-June-2000.

\begin{tabular}{cccccc}
\hline Date and Time & $\begin{array}{c}\text { Skellock } \\
\text { Temperature } \\
\left({ }^{\circ} \mathrm{C}\right)\end{array}$ & $\begin{array}{c}\text { Diamond } \\
\text { Lake } \\
\text { Temperature } \\
\left({ }^{\circ} \mathrm{C}\right)\end{array}$ & $\begin{array}{c}\text { Skellock ET } \\
(\mathrm{mm})\end{array}$ & $\begin{array}{c}\text { Diamond } \\
\text { Lake ET } \\
(\mathrm{mm})\end{array}$ & \% Difference \\
\hline $7 / 16 / 20000: 00$ & 10.2 & 8.3 & 0.021 & 0.020 & $6 \%$ \\
$7 / 16 / 20002: 00$ & 4.7 & 8.3 & 0.009 & 0.011 & $-14 \%$ \\
$7 / 16 / 20004: 00$ & 1.9 & 7.2 & 0.007 & 0.009 & $-23 \%$ \\
$7 / 16 / 20006: 00$ & 2.0 & 8.9 & 0.007 & 0.009 & $-30 \%$ \\
$7 / 16 / 20008: 00$ & 6.1 & 16.7 & 0.030 & 0.040 & $-32 \%$ \\
$7 / 16 / 200010: 00$ & 12.8 & 18.3 & 0.094 & 0.106 & $-13 \%$ \\
$7 / 16 / 200012: 00$ & 22.4 & 22.2 & 0.474 & 0.473 & $0 \%$ \\
$7 / 16 / 200014: 00$ & 24.1 & 21.7 & 0.220 & 0.212 & $4 \%$ \\
$7 / 16 / 200016: 00$ & 27.1 & 22.2 & 0.403 & 0.376 & $7 \%$ \\
$7 / 16 / 200018: 00$ & 24.8 & 17.8 & 0.151 & 0.134 & $12 \%$ \\
$7 / 16 / 200020: 00$ & 20.9 & 13.3 & 0.039 & 0.033 & $16 \%$ \\
$7 / 16 / 200022: 00$ & 15.0 & 11.7 & 0.025 & 0.023 & $9 \%$ \\
$7 / 17 / 20000: 00$ & 11.2 & 9.4 & 0.014 & 0.014 & $6 \%$ \\
\hline Total & & & 1.50 & 1.46 & $3 \%$ \\
\hline
\end{tabular}

parameters has a significant effect in the calculation of evapotranspiration, particularly if several parameters are altered. Because of this, evapotranspiration is only applied to the lower elevation (below $1500 \mathrm{~m}$ ) in the basin and as a result, volumetric evapotranspiration calculated below is underestimated by up to $50 \%$.

Table 4 - Sensitivity of evapotranspiration to $50 \%$ variation in meterological parameters.

\begin{tabular}{cccccc}
\hline $50 \%$ change in: & Temperature & $\begin{array}{c}\text { Wind } \\
\text { Speed }\end{array}$ & Humidity & $\begin{array}{c}\text { Barometeric } \\
\text { Pressure }\end{array}$ & $\begin{array}{c}\text { Solar } \\
\text { Radiation }\end{array}$ \\
\hline $\begin{array}{c}\text { Resulting change in } \\
\text { ET }\end{array}$ & $19 \%$ & $3 \%$ & $9 \%$ & $8 \%$ & $42 \%$ \\
\hline
\end{tabular}

The volume of evapotranspiration was calculated for each sub-region by multiplication of evapotranspiration by the area of each sub-region. This volume then 
was subtracted from the volume of precipitation for each sub-region, yielding a volume of water that is available to recharge aquifers (Table 5, Table 6, Table 7).

Table 5 - Evapotranspiration (ET) volume using ET from this study $(52.1 \mathrm{~cm})$ and residual volume available for recharge. It should be noted that this ET represents only mid-June through late-October, so it is lower than ET for entire 2000 growing season.

\begin{tabular}{cccccccc}
\hline & Area 1 & Area 2 & Area 3 & $\begin{array}{c}\text { Area 4- } \\
\text { Antelope } \\
\text { Desert }\end{array}$ & $\begin{array}{c}\text { Area 4- } \\
\text { Cascades }\end{array}$ & Area 5 & Total \\
\hline \hline $\begin{array}{c}\text { Mean } \\
\begin{array}{c}\text { Precipitation } \\
\text { Volume }\left(\mathrm{m}^{3}\right)\end{array}\end{array}$ & $3.62 \times 10^{8}$ & $2.16 \times 10^{8}$ & $4.89 \times 10^{8}$ & $5.91 \times 10^{8}$ & $8.31 \times 10^{8}$ & $2.57 \times 10^{8}$ & $2.75 \times 10^{9}$ \\
$\begin{array}{c}\text { ET volume }\left(\mathrm{m}^{3}\right) \\
\text { from this study } \\
(52.1 \mathrm{~cm})\end{array}$ & $7.20 \times 10^{7}$ & $1.77 \times 10^{8}$ & $1.32 \times 10^{8}$ & $3.46 \times 10^{8}$ & $8.80 \times 10^{7}$ & $1.68 \times 10^{8}$ & $9.83 \times 10^{8}$ \\
$\begin{array}{c}5 \text { Difference } \\
\text { Between ET } \\
\text { volume and }\end{array}$ & $2.90 \times 10^{8}$ & $3.90 \times 10^{7}$ & $3.57 \times 10^{8}$ & $2.45 \times 10^{8}$ & $7.43 \times 10^{8}$ & $8.90 \times 10^{7}$ & $1.76 \times 10^{9}$ \\
\begin{tabular}{c} 
Precipitation $\left(\mathrm{m}^{3}\right)$ \\
\hline
\end{tabular} & & & & & & & \\
\hline
\end{tabular}

Table 6 - Evapotranspiration volume using ET from Bidlake (1997) (average=68.4 $\mathrm{cm})$ and residual volume available for recharge.

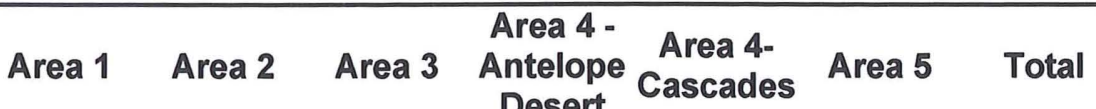

\begin{tabular}{|c|c|c|c|c|c|c|c|}
\hline $\begin{array}{c}\text { Mean } \\
\text { Precipitation } \\
\text { Volume }\left(\mathrm{m}^{3}\right)\end{array}$ & $3.62 \times 10^{8}$ & $2.16 \times 10^{8}$ & $4.89 \times 10^{8}$ & $5.91 \times 10^{8}$ & $8.31 \times 10^{8}$ & $2.57 \times 10^{8}$ & $2.75 \times 10^{9}$ \\
\hline $\begin{array}{c}\text { ET volume }\left(\mathrm{m}^{3}\right) \\
\text { from Bidlake } \\
(1997)(\text { Avg }=68.4 \\
\mathrm{cm})\end{array}$ & $9.40 \times 10^{7}$ & $2.33 \times 10^{8}$ & $1.74 \times 10^{8}$ & $4.55 \times 10^{8}$ & $1.15 \times 10^{8}$ & $2.21 \times 10^{8}$ & $1.29 \times 10^{9}$ \\
\hline $\begin{array}{c}\text { Difference } \\
\text { Between ET and } \\
\text { Precipitation }\left(\mathrm{m}^{3}\right)\end{array}$ & $2.68 \times 10^{8}$ & $-1.70 \times 10^{7}$ & $3.15 \times 10^{8}$ & $1.36 \times 10^{8}$ & $7.16 \times 10^{8}$ & $3.60 \times 10^{7}$ & $1.45 \times 10^{9}$ \\
\hline
\end{tabular}


Table 7 - Evapotranspiration volume using ET from Bidlake and Payne (1998) (91.1 $\mathrm{cm}$ ) and residual volume available for recharge.

\begin{tabular}{|c|c|c|c|c|c|c|c|}
\hline & Area 1 & Area 2 & Area 3 & $\begin{array}{l}\text { Area } 4 \text { - } \\
\text { Antelope } \\
\text { Desert }\end{array}$ & $\begin{array}{l}\text { Area 4- } \\
\text { Cascades }\end{array}$ & Area 5 & Total \\
\hline $\begin{array}{l}\text { Mean } \\
\text { Precipitation } \\
\text { Volume }\left(\mathrm{m}^{3}\right)\end{array}$ & $3.62 \times 10^{8}$ & $2.16 \times 10^{8}$ & $4.89 \times 10^{8}$ & $5.91 \times 10^{8}$ & $8.31 \times 10^{8}$ & $2.57 \times 10^{8}$ & $2.75 \times 10^{9}$ \\
\hline $\begin{array}{l}\text { ET volume }\left(\mathrm{m}^{3}\right) \\
\text { from Bidlake and } \\
\text { Payne }(1998) \\
(91.1 \mathrm{~cm})\end{array}$ & $1.25 \times 10^{8}$ & $3.10 \times 10^{8}$ & $2.31 \times 10^{8}$ & $6.05 \times 10^{8}$ & $1.54 \times 10^{8}$ & $2.94 \times 10^{8}$ & $1.72 \times 10^{9}$ \\
\hline $\begin{array}{c}\text { Difference } \\
\text { Between ET and } \\
\text { Precipitation }\left(\mathrm{m}^{3}\right)\end{array}$ & $2.37 \times 10^{8}$ & $-9.40 \times 10^{7}$ & $2.58 \times 10^{8}$ & $-1.40 \times 10^{7}$ & $6.77 \times 10^{8}$ & $-3.70 \times 10^{7}$ & $1.03 \times 10^{9}$ \\
\hline
\end{tabular}

Using the evapotranspiration estimates from this study, Bidlake (1997), and Bidlake and Payne (1998), precipitation volume after removal of evapotranspiration volume ranges from 1.764 billion $\mathrm{m}^{3}$ to 1.029 billion $\mathrm{m}^{3}$ (Table 5, Table 6, Table 7) over the entire basin. It should be noted that the evapotranspiration value from this study only represents evapotranspiration from mid-June through October and underestimates the annual evapotranspiration. Note that using evapotranspiration values from Bidlake (1997) and Bidlake and Payne (1998) evapotranspiration exceedes precipitation in Area 2 , resulting in a negative volume of potential recharge. These negative values are not necessarily realistic in terms of removing extra water from these areas, but likely indicate vegetation is severely stressed during periods of low precipitation. The negative values also indicate that these areas have extremely limited recharge potential to local and regional aquifers. Using Bidlake and Payne (1998) data, negative volumes are also found in Area 4-Antelope Desert and Area 5. Ranking for each sub-region in terms of potential recharge volume using evapotranspiration values from all three 
studies (all three produced the same ranking) from highest to lowest is shown in Table 8.

Table 8 - Ranking of sub-regions from highest to lowest precipitation volume after subtraction of evapotranspiration volume.

\begin{tabular}{ccc}
\hline Rank & Sub-Area & Potential Recharge Range \\
\hline \hline 1 & Area 4-Cascades & $743,00,000-677,000,000 \mathrm{~m}^{3}$ \\
2 & Area 3 & $357,000,000-258,000,000 \mathrm{~m}^{3}$ \\
3 & Area 1 & $290,000,000-237,000,000 \mathrm{~m}^{3}$ \\
4 & Area $4-$ Antelope Desert & $245,000,000-(-14,000,000) \mathrm{m}^{3}$ \\
5 & Area 5 & $89,000,000-(-37,000,000) \mathrm{m}^{3}$ \\
6 & Area 2 & $39,000,000-(-94,000,000) \mathrm{m}^{3}$ \\
\hline
\end{tabular}

\section{Pyroclastic Material}

The mid-Holocene eruptions of Mount Mazama produced pyroclastic material that make up the surface deposits surrounding Klamath Marsh. The Llao Rock eruption (7,015 \pm 45 , Bacon, 1983), the Cleetwood eruption (weeks to months before climactic eruption, Bacon, 1983), and the climactic eruption $\left(6,845 \mathrm{C}^{14} \mathrm{yr}\right.$. , Bacon, $1983 ; 7,627 \pm$ 150 cal. Yr. B.P., Zdanowicz et al., 1999) produced pumicaeous pyroclastic-fall and flow materials that mantle topography and fill paleo-river and stream channels, respectively. The climactic eruption produced more than $20 \mathrm{~km}^{3}$ of tephra (dense-rock equivalent) that was distributed over 1.7 million $\mathrm{km}^{2}$ in North America and had a plume height of $55 \mathrm{~km}$ during the Plinian phase of the eruption (Gardner et al., 1998). These deposits cover the topography around Klamath Marsh with up to $4.5 \mathrm{~m}$ of pumice, ash, and lithic materials (Conaway and Cummings, 2000). 
The pyroclastic deposits from the eruptions of Mount Mazama surrounding Klamath Marsh can be broken into three categories: Pyroclastic-fall, pyroclastic-flow, and reworked deposits. Pyroclastic-fall deposits are the most widespread unit. Average thickness of this unit southeast of the marsh is 3 meters (Conaway and Cummings, 2000). Pyroclastic-flow deposits generally consist of fine-grained ash with few pumice clasts $(<10 \%)$, but can be variable (Conaway and Cummings, 2000). These deposits were emplaced during the climactic eruption when pyroclastic flows moved down drainages on the eastern flank of Mount Mazama. These deposits range from $25 \mathrm{~m}$ (estimated from water well logs) to 5 meters thick in the Wocus Bay quadrangle (Conaway and Cummings, 2000). The reworked deposits consist of rounded pumice clasts and are a result of fluvial and lacustrine reworking of pyroclastic-fall and -flow deposits. These three units make up the surface units in the Williamson River basin.

In this section we examine how water infiltrates through pyroclastic-fall and-flow deposits. The capacity of these deposits to retain water has not been studied, and could have substantial influence on the way precipitation recharges aquifers. Water content in pyroclastic-fall deposits was examined at several times during 2000-2001 to determine relationships with timing of infiltration, grain size, and depth. Infiltration rate of pyroclastic-flow deposits near Sand Creek is also determined.

Pyroclastic-fall

Six hand-augered holes at the same site (Figure 13) were completed during 2000 - 2001 in section 17, T. 32 S., R. 9 E. (UTM location: 609040E, 4739101N) for the purpose of examining water content in the pyroclastic-fall material. This location (Figure 13) is in the Wocus Bay Quadrangle, roughly $2.4 \mathrm{~km}$ southeast of Klamath 
Marsh and was chosen because it is in a relatively undisturbed upland forest area with thick deposits of pyroclastic-fall material.

All samples were placed in plastic zip-lock bags and returned to the laboratory at Portland State University within a couple days of sampling. At the lab, each sample was split, using the conical pile splitting technique, into a sample size that could be dried, weighed and sieved. The samples were weighed and placed in a drying oven for 24 hours. The samples were then weighed again to get a dry weight for each sample. The samples were sieved for 10 minutes through $64 \mathrm{~mm}, 2 \mathrm{~mm}$, and $.0625 \mathrm{~mm}$ sieves. These particular sizes are recommended by Schmid (1981) for pyroclastic materials. Schmid (1981) pyroclastic material grain size intervals are as follows: $>64 \mathrm{~mm}$ bomb, block, $64 \mathrm{~mm}-2 \mathrm{~mm}$ - lapillus, $2 \mathrm{~mm}-0.0625 \mathrm{~mm}$ - coarse ash, $<0.0625 \mathrm{~mm}$ fine ash. The sizes selected distinguish blocks $(>64 \mathrm{~mm})$ from lapilli and lapilli from coarse ash $(2 \mathrm{~mm})$ and course ash from fine ash $(<0.0625 \mathrm{~mm})$. 


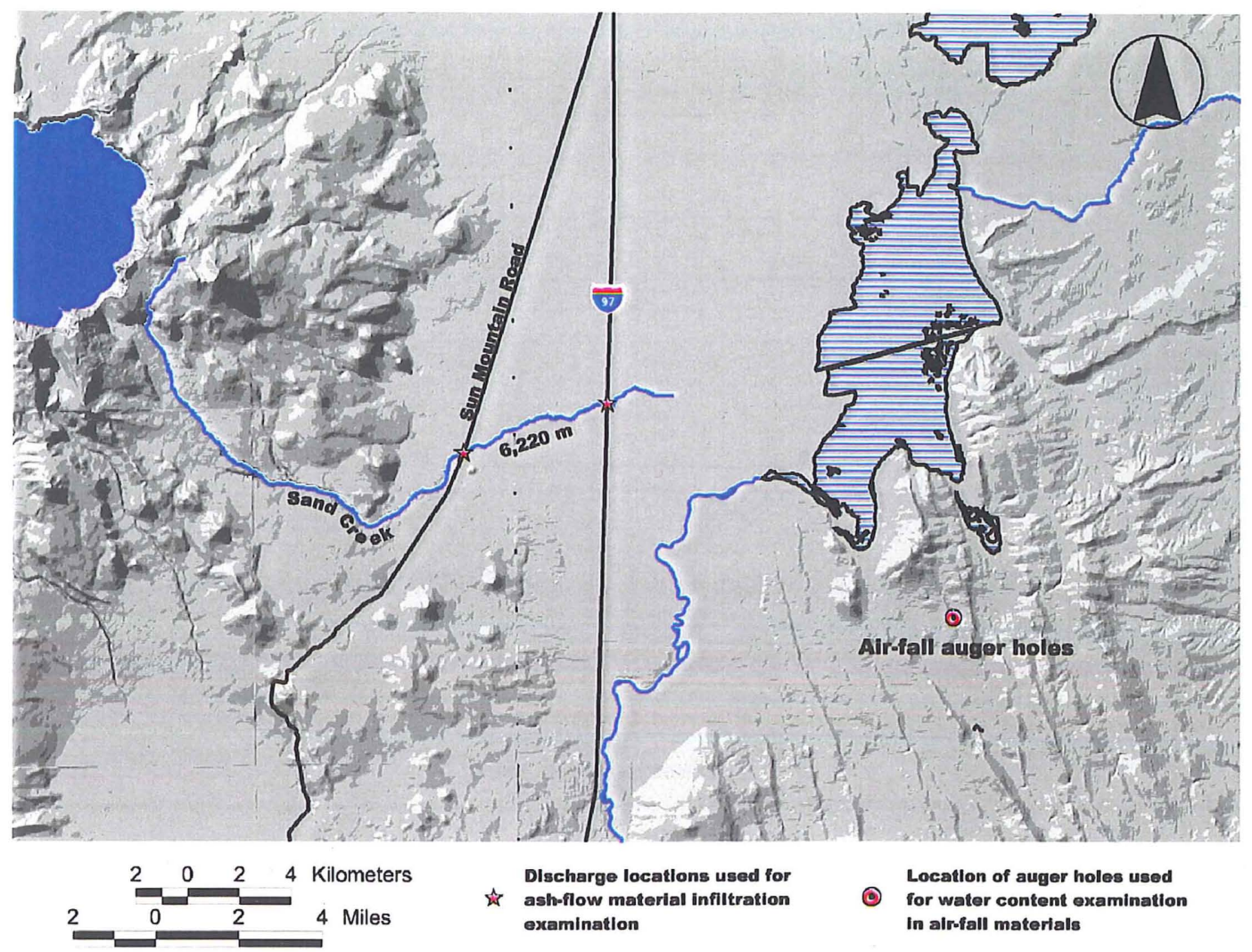

Figure 13 - Location of hand-auger samples for air-fall material examination and location of gaging points on Sand Creek used for ash-flow infiltration examination.

Figure 14 - 19 show the percent water by mass and grain size with depth in samples acquired on several dates during 2000-2001. The $64 \mathrm{~mm}-2 \mathrm{~mm}$ (lapillus) grain size appears to control moisture content in all sampling dates. This observation is supported by a statistical analysis (Table 9) of correlation between the different grain sizes and water content within the samples. 


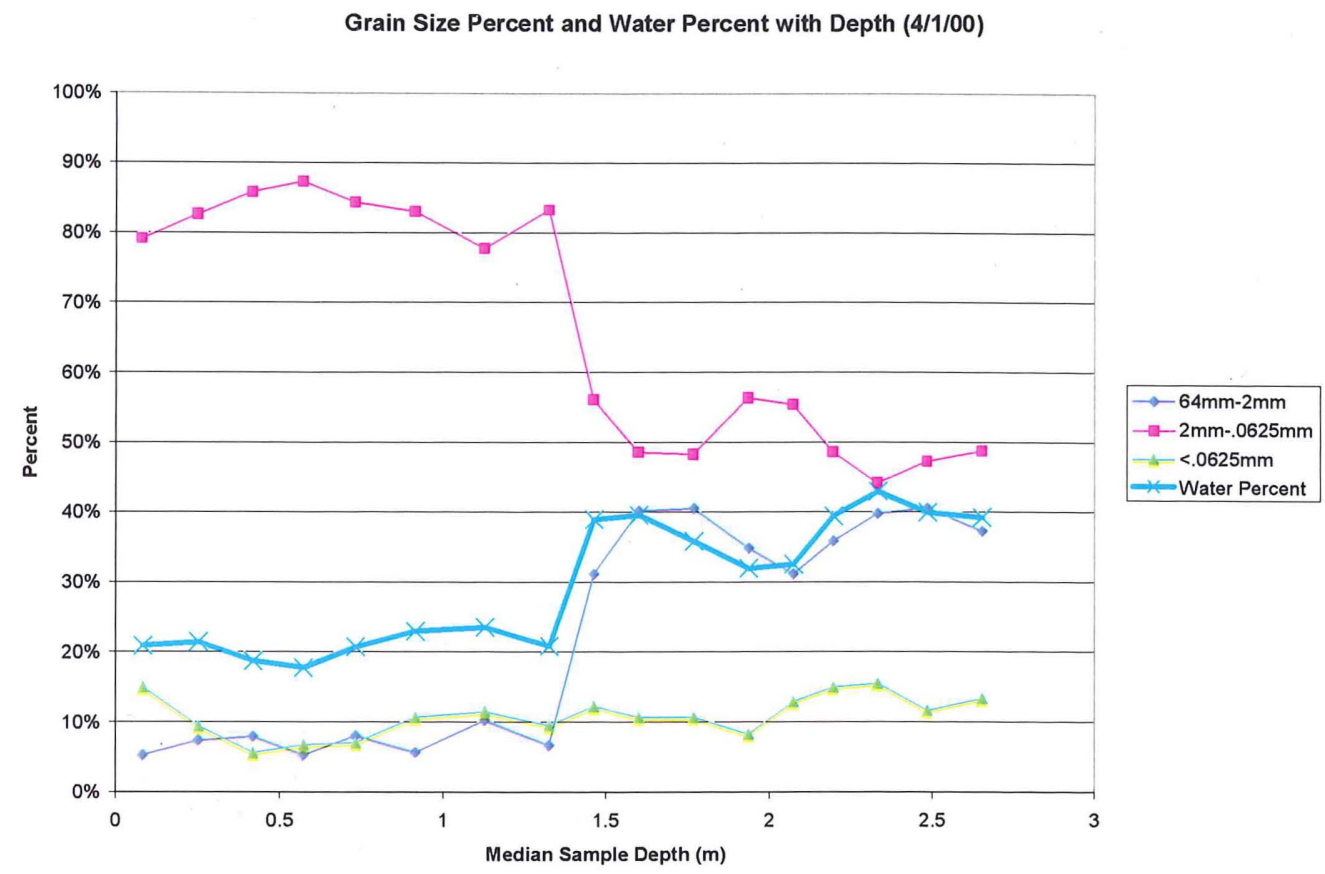

Figure 14 - Grain size weight percent and water weight percent with depth for samples taken on 1-April-00.

Grain Size Percent and Water Percent with Depth (4/30/00)

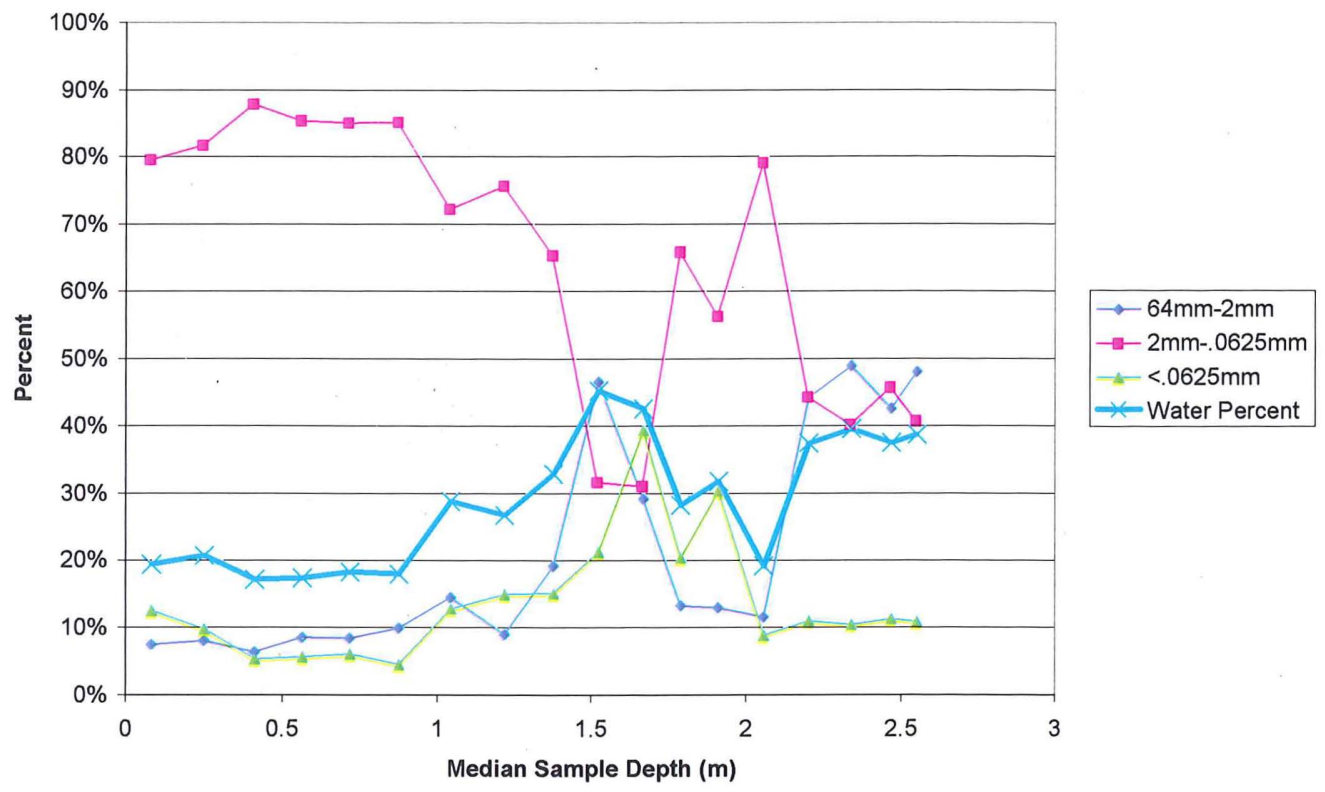

Figure 15 - Grain size weight percent and water weight percent with depth for samples taken on 30-April-00. 


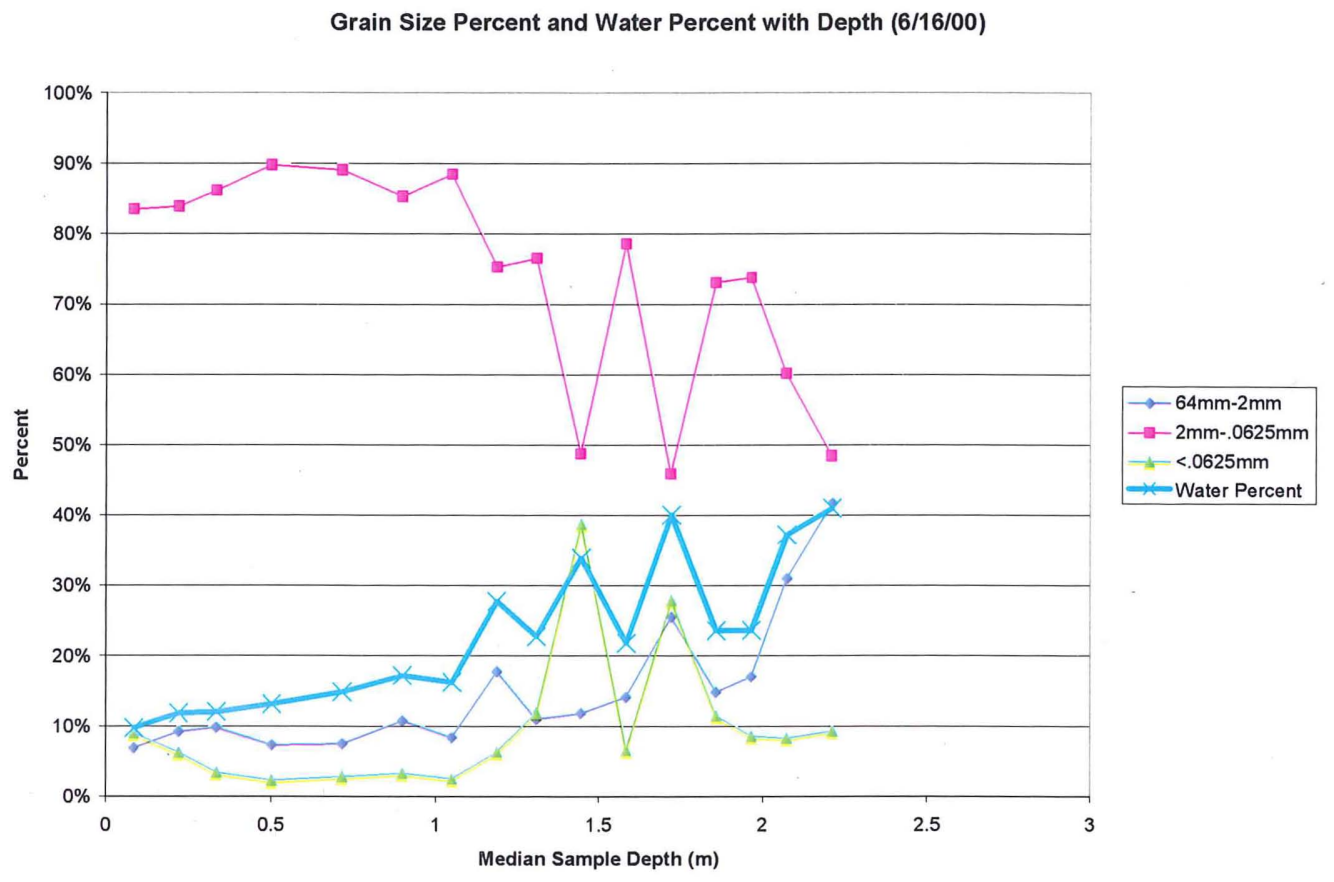

Figure 16 - Grain size weight percentage and water weight percent with depth for samples taken on 16-June-00.

Grain Size Percent and Water Percent with Depth (7/20/00)

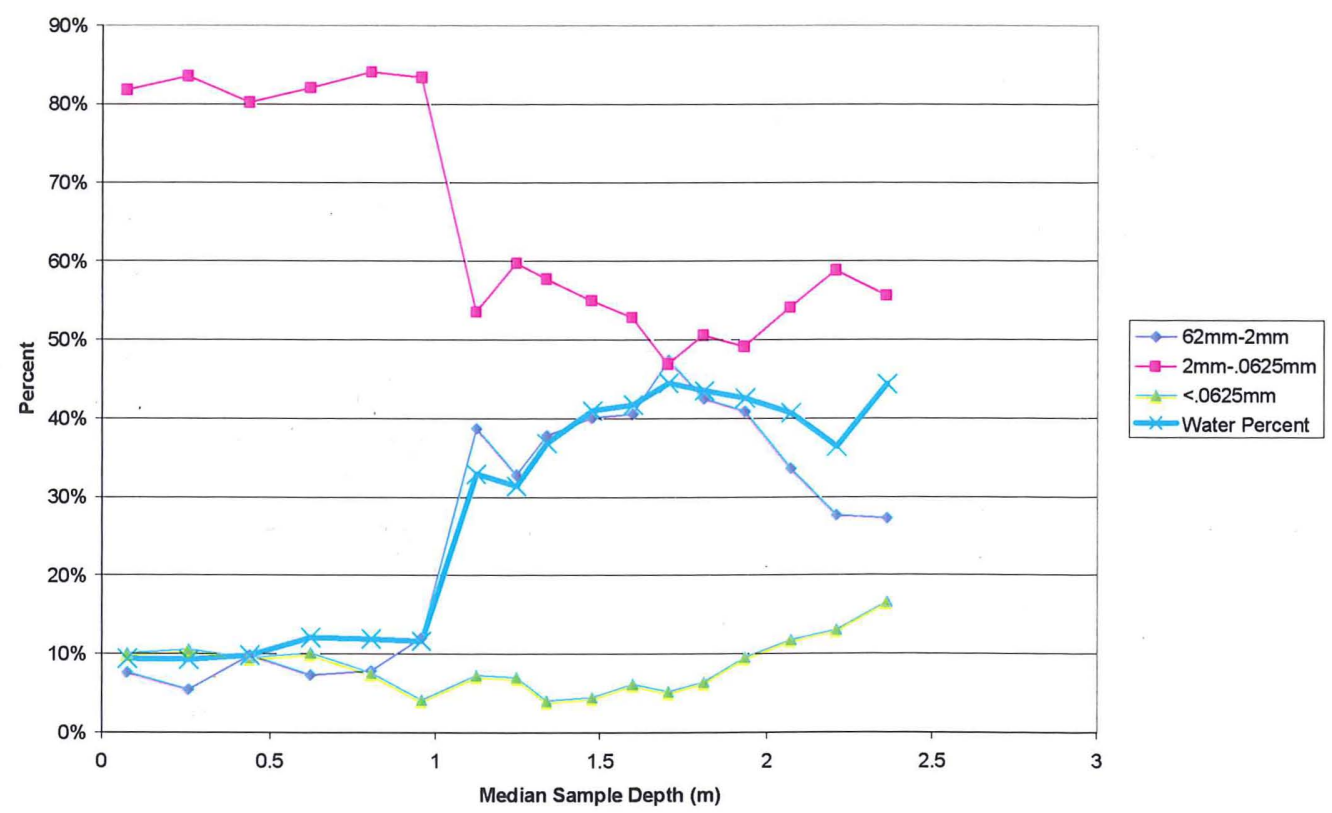

Figure 17 - Grain size weight percent and water weight percent with depth from samples taken on 20-July-00. 


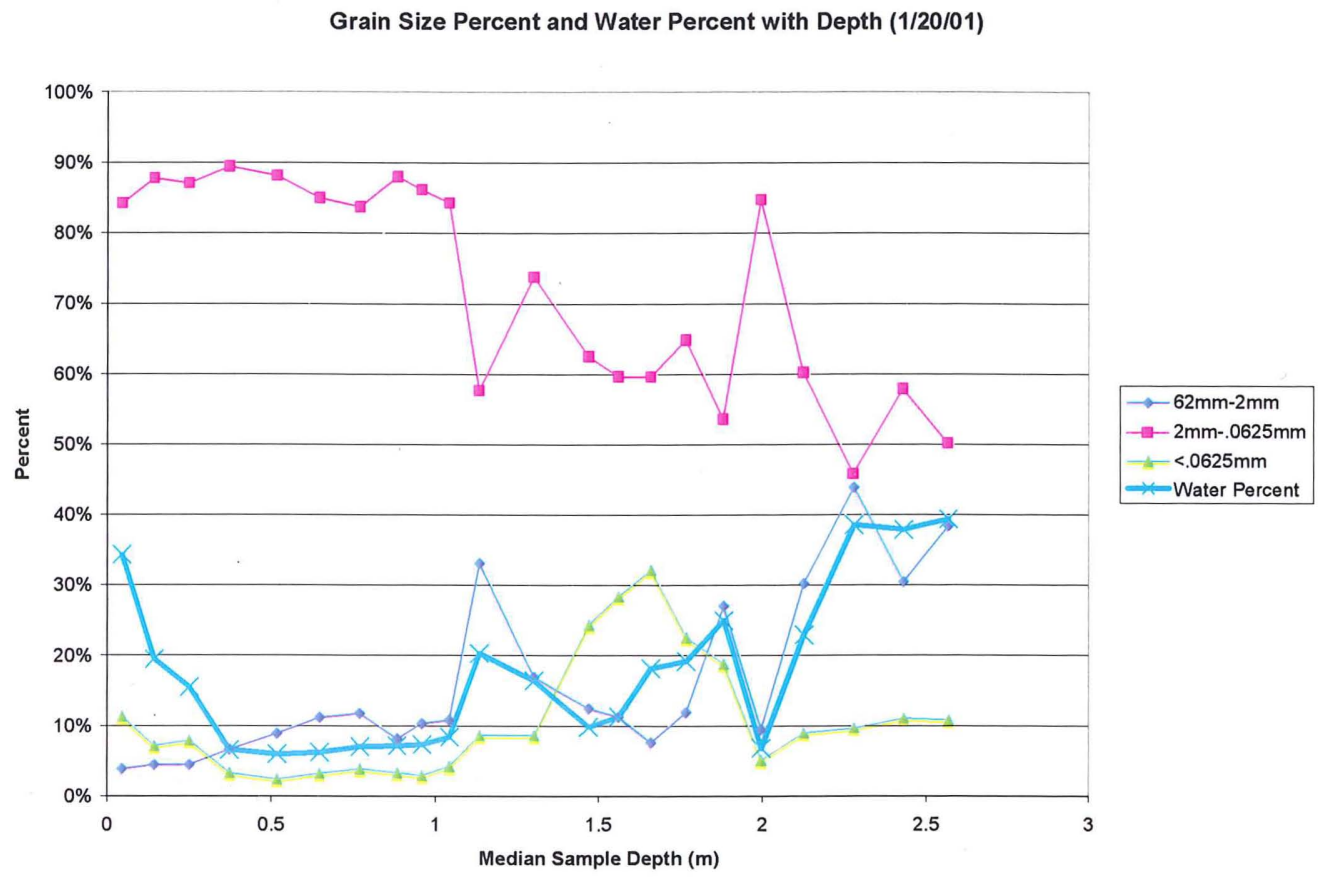

Figure 18 - Grain size weight percent and water weight percent with depth from samples taken on 20-Jan-01.

Grain Size Percent and Water Percent with Depth (4/27/01)

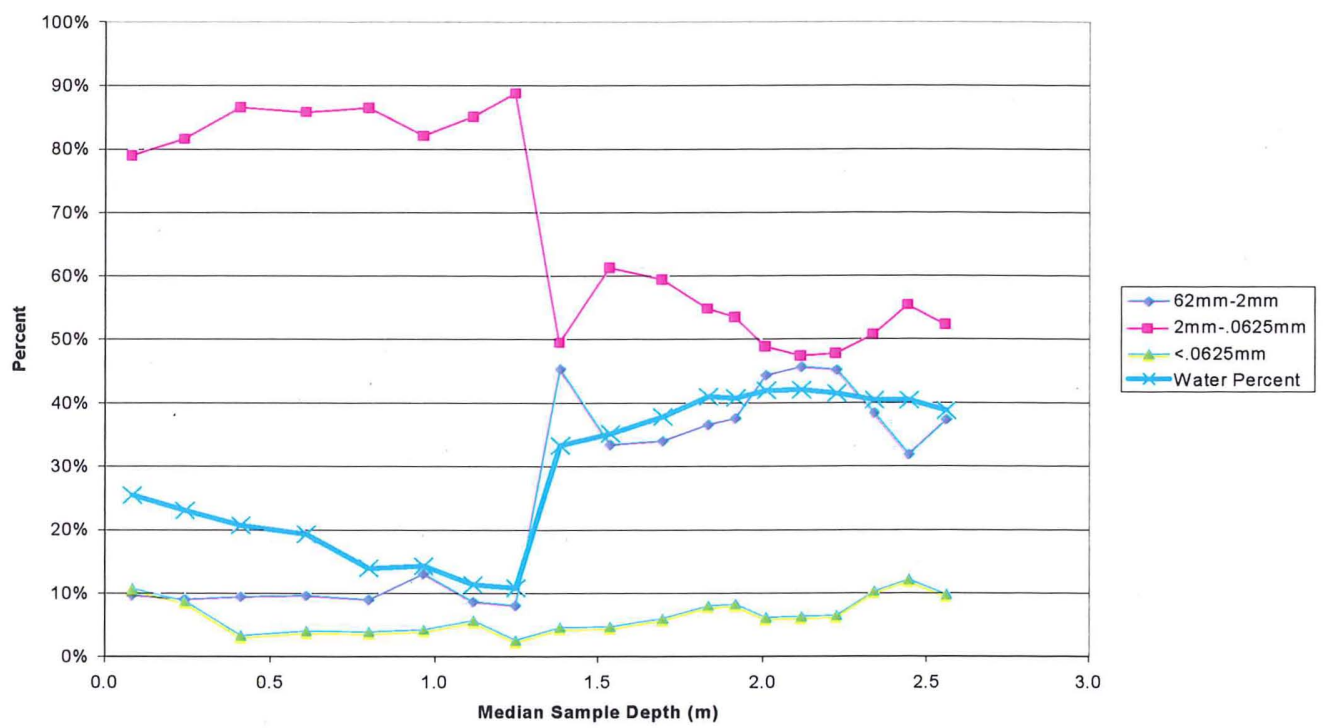

Figure 19 - Grain size weight percent and water weight percent with depth from samples taken on 27-April-01. 
Table 9 - Correlation coefficient between each grain size and water percentage by weight.

\begin{tabular}{ccccccc}
\hline & 1-Apr- & $30-$ Apr- & 16-Jun- & 20-July- & 20-Jan- & 27-Apr- \\
& 2000 & 2000 & 2000 & 2000 & 2001 & 2001 \\
\hline \hline $\begin{array}{c}\text { Correlation lapillus - water } \\
\text { percent }\end{array}$ & 0.96 & 0.87 & 0.86 & 0.94 & 0.69 & 0.92 \\
$\begin{array}{c}\text { Correlation coarse ash - water } \\
\text { percent }\end{array}$ & -0.98 & -0.98 & -0.94 & -0.98 & -0.68 & -0.95 \\
$\begin{array}{c}\text { Correlation fine ash - water } \\
\text { percent }\end{array}$ & 0.62 & 0.59 & 0.60 & -0.02 & 0.23 & 0.55 \\
\hline
\end{tabular}

A correlation coefficient of 1 shows direct correlation between data sets and a coefficient of -1 shows no correlation at all between data sets. The correlation coefficient between the weight percentage of grain sizes $64 \mathrm{~mm}-2 \mathrm{~mm}$ (lapillus) in each sample and water content percentage of those same samples, produce values ranging from 0.96 to 0.69 , indicating a correlation between these two sets of data. The correlation for the 20-Jan-01 samples is skewed because of a frozen layer in the upper $0.5 \mathrm{~m}$ of the auger hole. When these samples are removed the mean correlation coefficient between the lapillus grain size and water content is 0.91 . The correlation coefficient between $2 \mathrm{~mm}-.0625 \mathrm{~mm}$ (coarse ash) grain size weight percent and water content, produce values ranging from -98 to -64 , indicating an inverse relationship between this particular grain size and water content of the sample. Again, the 20-Jan-01 is skewed by the frozen layer and when removed, the average correlation coefficient is 0.97. The correlation coefficient between $<.0625 \mathrm{~mm}$ (fine ash) grain size and water content, produce values that show little to no correlation between the two data sets. From these data it may be concluded that pumice lapilli hold more water on a constant mass basis than coarse and fine ash. 
Generally, coarse ash $(2 \mathrm{~mm}-0.0625 \mathrm{~mm})$ is the dominant grain size in all samples, with a sharp increase in the lapilli $(64 \mathrm{~mm}-2 \mathrm{~mm})$ size below $1.5 \mathrm{~m}$.

Examination of bulk water percentage by weight among all the samples indicates the average water content was $27 \%$, with the highest water content (by weight) of $45 \%$ occurring at a depth range of 4.75 to $5.26 \mathrm{~m}$ on 30 -April-00 and the lowest water content (by weight) of $9 \%$ occurring at a depth range of 0.5 to $1.5 \mathrm{~m}$ on $20-\mathrm{Jul}-00$. Average bulk water weight percentage (Table 10) drops from 30\% in April, 2000, dropping through the summer, and is replenished again in the spring of 2001 (27-Apr$01)$.

Table 10 - Bulk water percentage in all samples.

\begin{tabular}{cc}
\hline Sample Date & $\begin{array}{c}\text { Bulk Water Weight } \\
\text { Percentage }\end{array}$ \\
\hline \hline 1-Apr-2000 & $30 \%$ \\
30-Apr-2000 & $29 \%$ \\
16-Jun-2000 & $23 \%$ \\
20-July-2000 & $30 \%$ \\
20-Jan-2001 & $18 \%$ \\
27-Apr-2001 & $30 \%$ \\
\hline Average & $27 \%$ \\
\hline
\end{tabular}

Pyroclastic-flow

Sand and Scott creeks drain the eastern side of Mount Scott and ancestral Mount Mazama, flowing across pyroclastic-flow deposits that slope gently toward Klamath Marsh. Change in discharge on Sand Creek (Figure 13) between two locations where the stream flows over pyroclastic-flow material was used to estimate infiltration into these deposits. A single experiment on 22-Oct-01 gaged discharge of Sand Creek at a bridge on Sun Mountain Road (discharge $=0.31 \mathrm{~m}^{3} / \mathrm{sec}$ ) and at Oregon Highway 97 (discharge $=0.19 \mathrm{~m}^{3} / \mathrm{sec}$ ). Discharge drops by $0.12 \mathrm{~m}^{3} / \mathrm{sec}$ between these two points 
and is assumed to be from infiltration into the pyroclastic-flow material in which Sand Creek has carved its stream channel.

A hand augered core near Scott Creek indicates that approximately $2 \mathrm{~m}$ of medium- to fine-grained sand overlies the pyroclastic-flow material in this area. Discharge was not observed in Scott Creek when this core was augered in the spring of 2000 and the sand was moist. Sand Creek lies to the south and is believed to have similar sand deposits under its channel. Flow was observed in Sand Creek at Highway 97 on all field visits, except when water in the channel was frozen on 18-Nov-00, 20Jan-01, and 17-Mar-01 (Table 23). It is likely that the sand underlying the channel on Sand Creek is saturated and in hydraulic equilibrium by late October when the discharge measurements were made for this analysis. If these sand deposits were saturated, then the change in discharge from Sun Mountain Road to Highway 97 reflects infiltration into the underlying pyroclastic-flow deposits.

In order to evaluate the infiltration rate, Darcy's law is applied, which states discharge (Q) equals hydraulic conductivity (K) multiplied by area (A) multiplied by hydraulic gradient $(\mathrm{J})$ or $\mathrm{Q}=\mathrm{KJA}$. In this case, the discharge loss between the two points is Q, the area over which the loss in discharge occurs is A, the hydraulic gradient term is one (1) because flow is vertical, and we are solving for hydraulic conductivity (K $=\mathrm{Q} / \mathrm{AJ})$. The area of the channel bottom over which the water is infiltrating between these two locations was calculated by multiplying the length of the channel by the width of the channel. The channel length between these two gaging points is $6200 \mathrm{~m}$, the channel width at Sun Mountain Road is $3.7 \mathrm{~m}$ and the channel width at Highway 97 is 
$1.5 \mathrm{~m}$. Since the channel width of Sand Creek is unknown between these two points, an area was calculated assuming each width. The discharge difference $(\mathrm{Q})$ divided by the two area calculations (A) multiplied by the hydraulic gradient $(\mathrm{J})$ of one, yields infiltration rates $(\mathrm{K})$ of $10^{-6} \mathrm{~m} \mathrm{~s}^{-1}$ and $10^{-5} \mathrm{~m} \mathrm{~s}^{-1}$ (Table 11). This infiltration rate is relatively low and suggests pyroclastic-fall deposits may act as a semi-confining layer.

Table 11 - Values used for the estimation of infiltration rate of pyroclastic-flow material.

\begin{tabular}{|c|c|c|c|c|c|}
\hline $\begin{array}{l}\text { Gaging location on } \\
\text { Sand Creek } \\
\end{array}$ & $\begin{array}{c}\text { Discharge } \\
\text { (Q) }\end{array}$ & $\begin{array}{l}\text { Channel } \\
\text { width }\end{array}$ & $\begin{array}{c}\text { Distance between } \\
\text { gaging locations }\end{array}$ & $\begin{array}{l}\text { Infiltration } \\
\text { Area (A) } \\
\end{array}$ & $\begin{array}{c}\text { Infiltration } \\
\text { rate }(\mathrm{K}) \\
\end{array}$ \\
\hline $\begin{array}{c}\text { Sun Mt. Rd. } \\
\text { Hwy } 97\end{array}$ & $\begin{array}{l}0.31 \mathrm{~m}^{3} \mathrm{~s}^{-1} \\
0.12 \mathrm{~m}^{3} \mathrm{~s}^{-1}\end{array}$ & $\begin{array}{l}3.7 \mathrm{~m} \\
1.5 \mathrm{~m}\end{array}$ & $6200 \mathrm{~m}$ & $\begin{array}{l}22940 \mathrm{~m}^{2} \\
9300 \mathrm{~m}^{2}\end{array}$ & $\begin{array}{l}10^{-6} \mathrm{~m} \mathrm{~s}^{-1} \text { to } \\
10^{-5} \mathrm{~m} \mathrm{~s}^{-1}\end{array}$ \\
\hline
\end{tabular}

\section{Geology and Bedrock Infiltration}

Regional ground and surface water features and their respective recharge areas in the Williamson River basin are separated into five areas shown in Figure 20 on the basis of bedrock geology and precipitation patterns. These are the same sub-regions described in the precipitation and evapotranspiration section. They are as follows: Upper Williamson River (Area 1), Skellock Upland (Area 2), Sugarpine Mountain (Area 3), Antelope Desert (Area 3), and Lower Williamson River (Area 5). A further distinction can be made among the five areas with respect to their location relative to the WRMC fault zone. In this section, recharge volume, geologic observations, water well yields, and piezometeric data in several areas will be used to determine which areas are important hydrogeologically. Areas east of the WRMC fault zone (Areas 1, 2, and 3) reflect geology less conducive to groundwater flow coupled with low recharge potential and tend to be regarded as minor in their contribution to the hydrologic system as a 
whole. Areas west of the WRMC fault zone (Areas 4 and 5) are underlain by much more permeable materials and display higher recharge potential from relatively higher precipitation in the Cascade Range.

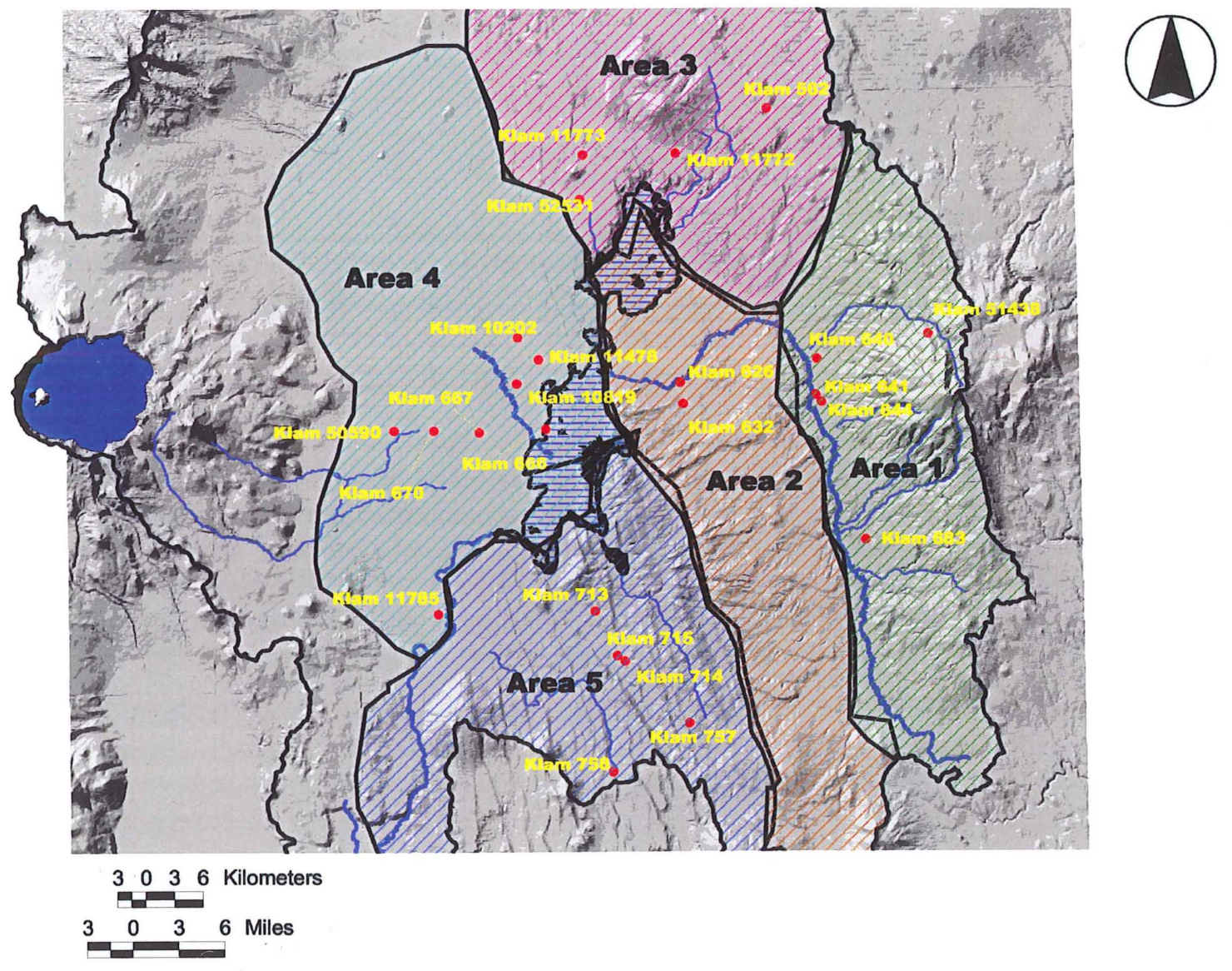

Figure 20 - Location of areas used to describe geology with relative well log locations. Well logs are located in Appendix B. Area 1 - Upper Williamson, Area 2 - Skellock Upland, Area 3 - Sugarpine Mountain, Area 4 - Antelope Desert, Area 5 - Lower Williamson River.

Upper Williamson River - (Area 1)

The area from the headwaters of the Williamson River to the western bend of the Williamson toward Klamath Marsh (Figure 20) is geologically characterized by lava and pyroclastic flows on the western flank of Yamsay Mountain and alluvial materials 
interbedded with lava flows on the valley bottom (Table 12). Water wells in the

Williamson River valley bottom indicate low to moderate yields (average yield $=44$

gpm) in consolidated and unconsolidated sediments and fractured lava flows, with one

well (Klam 641) completed in alluvium and lavas yielding 1800 gpm (Table 12). This

area ranks third in recharge volume among the sub-regions with 237 million to 291

million $\mathrm{m}^{3}$.

Table 12 - Summary of recharge, geology and water well yields in Area 1.

\begin{tabular}{|c|c|c|c|}
\hline $\begin{array}{c}\text { Mean } \\
\text { Precipitation }\end{array}$ & $\begin{array}{l}\text { Precipitation } \\
\text { Volume }\end{array}$ & Evapotranspiration Volume & Recharge Volume \\
\hline $66.5 \mathrm{~cm}$ & 362 million $\mathrm{m}^{3}$ & 72 million to 125 million $\mathrm{m}^{3}$ & 237 million to 290 million $\mathrm{m}^{3}$ \\
\hline \multicolumn{4}{|c|}{$\begin{array}{l}\text { The geology of Yamsay Mountain is described by Hering (1981) as developing in four stages of activity. } \\
\text { Stage } 1 \text { consists of porphyritic basaltic andesite shield lavas and porphyritic rhyolitic lavas. During stage } \\
\text { 2, a lithic welded tuff with well-developed eutaxitic texture was erupted. Stage } 3 \text { consists of dacite } \\
\text { erupted from circumferential fractures near the summit indicating the onset of caldera development and } \\
\text { eruption of aphyric basaltic andesite. Eruptions of dacite, then porphyritic basaltic andesite, followed by } \\
\text { additional dacite eruptions characterize stage } 4 \text {. Geologic logs from water wells in the flood plain of the } \\
\text { Williamson River indicate up to } 70 \mathrm{~m} \text { (Klam } 641 \text { ) of alluvial sediment interbedded with volcanic flow } \\
\text { materials. Surficial deposits are predominately mantling pyroclastic-fall deposits from the eruptions of } \\
\text { Mount Mazama. Pyroclastic-fall deposits in areas below } 1402 \mathrm{~m} \text { elevation (Williamson River valley) } \\
\text { have been reworked during backflooding of Klamath Marsh after the climactic eruption of Mount } \\
\text { Mazama. }\end{array}$} \\
\hline \multicolumn{4}{|c|}{ Well Yields (Average yield* = 44 gpm) } \\
\hline OWRD well & \# (Figure 20) & Pump test yield & Water-bearing unit \\
\hline $\begin{array}{r}\text { Kle } \\
\text { Dept }\end{array}$ & $\begin{array}{l}683 \\
=107\end{array}$ & $\begin{array}{c}15 \text { gpm with } 25^{\prime} \text { drawdown after } \\
1.5 \text { hours }\end{array}$ & Red cinders and fine gravel \\
\hline $\begin{array}{r}\text { Kla } \\
\text { Dept }\end{array}$ & $\begin{array}{l}644 \\
=110^{\prime}\end{array}$ & 100 gpm (airlift test) & Broken lava and conglomerate \\
\hline $\begin{array}{l}\text { Klar } \\
\text { Dept }\end{array}$ & $\begin{aligned} & 1438 \\
= & 145^{\prime}\end{aligned}$ & 40 gpm (airlift test) & Black lava rock and gravel \\
\hline $\begin{array}{r}\text { Kla } \\
\text { Dept }\end{array}$ & $\begin{aligned} & 641 \\
= & 290\end{aligned}$ & $\begin{array}{c}1800 \text { gpm with } 71^{\prime} \text { drawdown } \\
\text { after } 2.5 \text { hours }\end{array}$ & $\begin{array}{l}\text { Brown lava, pumice, sand, } \\
\text { hard grey basalt, broken lava }\end{array}$ \\
\hline $\begin{aligned} \mathrm{Kla} \\
\mathrm{Dept}\end{aligned}$ & $\begin{array}{l}640 \\
=231\end{array}$ & $\begin{array}{l}20 \text { gpm with } 15^{\prime} \text { drawdown after } \\
4 \text { hours }\end{array}$ & $\begin{array}{l}\text { Conglomerate, sand, pumice, } \\
\text { grey basalt, loose gravel }\end{array}$ \\
\hline
\end{tabular}

*Klam 641 not included in average because it is not believed to be indicative of overall aquifer yield.

Additional information is available for each well in Appendix B. 
Skellock Upland (Area 2)

The geology of Area 2 is dominated by two pyroclastic flows that underlie lava flows and Mount Mazama pyroclastic-fall deposits. These tuffs appear to inhibit water flow as indicated by low water-well yields (average $=17.5 \mathrm{gpm}$, Table 13). This area has a low volume of recharge, ranking last among the sub-areas.

Table 13 - Summary of recharge, geology and water well yields in Area 2.

\begin{tabular}{|l|l|l|l|}
\hline $\begin{array}{c}\text { Mean } \\
\text { Precipitation }\end{array}$ & $\begin{array}{c}\text { Precipitation } \\
\text { Volume }\end{array}$ & Evapotranspiration Volume & Recharge Volume \\
\hline $53 \mathrm{~cm}$ & 216 million $\mathrm{m}^{3}$ & 177 million to 310 million $\mathrm{m}^{3}$ & -94 million to 39 million $\mathrm{m}^{3}$ \\
\hline
\end{tabular}

Geologic Summary:

Geology in the northern half of the area was mapped by Melady and Cummings (in preparation) in the Military Crossing quadrangle and Cummings et al. (in review) in the Wildhorse Ridge quadrangle. The area is characterized by two overlapping indurated pyroclastic flows up to $35 \mathrm{~m}$ thick. The tuff of Skellock draw is a lithic-bearing, partially welded rhyolitic tuff underlying the western half of Area 2. Overlapping this unit in the eastern half of Area 2 is the tuff of Meadow Creek, characterized by black trachyandesite pumice blocks up to $1 \mathrm{~m}$. Outcrop of these tuffs indicate limited hydraulic conductance. Overlying these units are basaltic andesite and trachydacite flows. Surficial deposits are predominately pyroclastic-fall deposits from the eruptions of Mount Mazama. Pyroclastic-fall deposits in areas below 1402 m elevation (most of Skellock Draw) were reworked during backflooding of Klamath Marsh after the climactic eruption of Mount Mazama.

\begin{tabular}{|c|c|c|}
\hline Well Yields (Average yield = $17.5 \mathrm{gpm})$ \\
\hline OWRD well log \# (Figure 20) & Pump test yield & Water-bearing unit \\
\hline Klam 626 & Conglomerate \\
Depth $=200^{\prime}$ & 15 gpm (drawdown unknown) & Black lava and sand \\
\hline Klam 632 & & \\
\hline Depth $=205^{\prime}$ & $\begin{array}{c}20 \text { gpm with } 60 \text { ' drawdown after } \\
1 \text { hour }\end{array}$ &
\end{tabular}

Additional information is available for each well in Appendix B.

In order to estimate the rate of infiltration into these two tuffs in a relative sense, eight piezometers were installed in Skellock Draw to examine rates of water decline in pyroclastic-fall and reworked deposits overlying the tuffs. Additionally, A preliminary water budget was calculated for Skellock Draw in an attempt to estimate the volume of 
water that could be infiltrating into underlying bedrock and estimate a rate of leakage. Recharge area in Skellock Draw was delineated from surrounding topography. Mean precipitation (1961-1990) was estimated at $54 \mathrm{~cm}$ from Figure 9. Infiltration into Mount Mazama pyroclastic deposits is at a high rate because of the grain size and structure of the pumice, but a relatively high percentage of recharge water becomes trapped within the pumice vesicles, failing to reach local water tables. Information on infiltration in pyroclastic air-fall deposits discussed earlier was applied, using estimations of $20 \%$ to $40 \%$ of recharge water reaching the saturated zone. Evapotranspiration rates were estimated at $52 \mathrm{~cm}$ from meteorological data acquired in Skellock Draw from mid-June through October, 2000. Based on field observations, discharge of Skellock Creek was estimated at $0.1-0.2 \mathrm{~m}^{3} \mathrm{~s}^{-1}$. Using these rough estimations of in- and out-flows in Skellock Draw, estimated leakage into material underlying wetlands ranges from $8.9 \mathrm{x}$ $10^{-6}-3.7 \times 10^{-6} \mathrm{~cm} \mathrm{~s}^{-1}$. These estimates are consistent with the physical characteristics of the tuffs.

The relative importance of Area 2 as a source of groundwater recharge is determined by using rate of decline of water levels in pyroclastic air-fall materials to evaluate relative rate of infiltration into the underlying bedrock surface. This technique is also used near Jack Creek in Area 3, and in Yoss Creek Meadow in Area 5. The rate of infiltration is used here in a relative sense among the three locations in which piezometers were monitored (Skellock Draw, Jack Creek, and Yoss Creek Meadow) and is not intended to assign actual vertical hydraulic conductivity to any materials. An evaluation of the validity of this approach is in order here. 
Darcy's Law which governs groundwater hydraulics states that groundwater discharge $(\mathrm{Q})$ equals hydraulic conductivity $(\mathrm{K})$ multiplied by hydraulic gradient $(\mathrm{J})$ multiplied by area (A) shown in the following equation:

$$
\mathrm{Q}=\mathrm{KJA}
$$

If horizontal groundwater discharge among Skellock Draw, Jack Creek, and Yoss Creek Meadow was similar, deviation between the areas in the rates of decline of water levels in piezometers would indicate differences in rates of vertical infiltration into underlying bedrock material. To show similar horizontal groundwater discharge in Skellock Draw, Jack Creek, and Yoss Creek Meadow, similarities must exist among the areas in hydraulic conductivity, hydraulic gradient, and area.

The hydraulic conductivity of the pyroclastic material (pyroclastic-fall and reworked pyroclastic-fall in Skellock Draw and Yoss Creek Meadow, and pyroclasticfall in Jack Creek) in these three areas based on observed characteristics in handaugered boreholes (Table 14) appears to be similar.

The hydraulic gradient is the slope of the water surface and is based on the elevation of water levels in piezometers at the upper and lower ends of Jack Creek (Upper and Lower Jack Creek Piezometers, Table 19), Skellock Draw (Upper and Lower Skellock Draw Piezometers, Table 19), and Yoss Creek Meadow (Upper and Lower Yoss, Table 19). Elevation of each piezometer was estimated from topographic maps with a contour interval of $6 \mathrm{~m}$. Error associated with the estimation of piezometer elevation may limit the effectiveness of this evaluation. Where available, benchmarks were used to better estimate elevation. Average depth of water level 
below ground surface was subtracted from the estimated elevation to yield an average water elevation at each piezometer. Water elevation of the lower piezometer in each area was subtracted from the upper piezometer to show the water level difference between the two piezometers. Distance between the upper and lower piezometers in each area was estimated using measuring function in ESRI Arcview. Water level difference was divided by distance between piezometers to yield a hydraulic gradient (Table 14) in Jack Creek, Skellock Draw, and Yoss Meadow.

The area used in Darcy's law is the area over which discharge is being calculated. Width of each drainage was estimated using measuring functions in ESRI Arcinfo and was multiplied by thickness estimates from Conaway and Cummings (in press) to calculate cross-sectional area for Skellock Draw (844 $\mathrm{m}^{2}$, Table 14), Jack Creek (929 $\mathrm{m}^{2}$, Table 14), and Yoss Creek Meadow (887 $\mathrm{m}^{2}$, Table 14).

Table 14 - Parameters used to estimate hydraulic conductivity, hydraulic gradient, and cross-sectional area similarities among Jack Creek, Skellock Draw, and Yoss Meadow. Observations of pumice characteristics were made during installation of piezometers. Hydraulic gradient was determined by using piezometers at the upper and lower ends of each area. Thickness approximation is based on Conaway and Cummings (in press).

\begin{tabular}{|c|c|c|c|}
\hline \multicolumn{4}{|c|}{ Hydraulic Conductivity (K) } \\
\hline & Jack Creek & Skellock Draw & Yoss Meadow \\
\hline $\begin{array}{l}\text { Description of } \\
\text { Pyroclastic Deposits }\end{array}$ & $\begin{array}{l}\text { Medium lapillus sized } \\
\text { pumice down to at } \\
\text { least } 2.2 \mathrm{~m}\end{array}$ & $\begin{array}{l}\text { Lapillus sized pumice } \\
\text { down to at least } 1.7 \mathrm{~m}\end{array}$ & $\begin{array}{c}\text { Cleetwood eruption } \\
\text { pumice (lapillus) down } \\
\text { to at least } 2.5 \mathrm{~m}\end{array}$ \\
\hline \multicolumn{4}{|l|}{ Hydraulic Gradient $(\mathrm{J})$} \\
\hline $\begin{array}{l}\text { Distance between } \\
\text { Piezometers }\end{array}$ & $3600 \mathrm{~m}$ & $5500 \mathrm{~m}$ & $1400 \mathrm{~m}$ \\
\hline $\begin{array}{l}\text { Approximate Elevation } \\
\text { of Upper and Lower } \\
\text { Piezometer }\end{array}$ & $\begin{array}{c}1399-1386 \mathrm{~m} \\
\Delta=13 \mathrm{~m}\end{array}$ & $\begin{array}{c}1408-1392 \mathrm{~m} \\
\Delta=16 \mathrm{~m}\end{array}$ & $\begin{array}{c}1383-1377 \mathrm{~m} \\
\Delta=6 \mathrm{~m}\end{array}$ \\
\hline $\begin{array}{l}\text { Average Water Level } \\
\text { Difference Between } \\
\text { Piezometers }\end{array}$ & $10.8 \mathrm{~m}$ & $15.0 \mathrm{~m}$ & $3.7 \mathrm{~m}$ \\
\hline Gradient $(\mathrm{J})$ & 0.003 & 0.0027 & 0.0026 \\
\hline
\end{tabular}




\begin{tabular}{|l|c|c|c|}
\hline Cross-sectional Area (A) & $4.5 \mathrm{~m}$ & $4.5 \mathrm{~m}$ \\
\hline $\begin{array}{l}\text { Approximate } \\
\text { Thickness of Deposit }\end{array}$ & $4.5 \mathrm{~m}$ & $187 \mathrm{~m}$ & $197 \mathrm{~m}$ \\
\hline $\begin{array}{l}\text { Width of Paleo- } \\
\text { channel }\end{array}$ & $206 \mathrm{~m}$ & $844 \mathrm{~m}^{2}$ & $887 \mathrm{~m}^{2}$ \\
\hline Area (A) & $929 \mathrm{~m}^{2}$ & & \\
\hline
\end{tabular}

With relative similarity (approximately $18 \%$ difference) established in groundwater discharge in the horizontal direction among these three areas, comparison of rates of water decline in piezometers in each area provides a method to relatively compare vertical infiltration rates of the underlying bedrock materials. Relatively high rates of water level decline indicate high vertical infiltration, with low rates of water level decline indicating low vertical infiltration.

Rates of water decline in Skellock Draw piezometers ranged from 2.41 to 0.04 $\mathrm{cm} /$ day with a mean of $0.35 \mathrm{~cm} /$ day (Table 15). Comparatively, these rates are relatively low, indicating that material underlying reworked pyroclastic-fall deposits in Skellock Draw likely have low infiltration rates. A low infiltration rate is consistent with the assertion that the tuff of Skellock Draw and the tuff of Meadow Creek underlie pyroclastic material in Skellock Draw. 
Table 15 - Rates of water level rise and decline in piezometers in Skellock Draw, Jack Creek, and Yoss Creek Meadow. Location of piezometers are shown in Figure 21 with letters keyed to Map ID in this table. Rates are in $\mathrm{cm}$ day $^{-1}$ and indicate rate of water level change between dates shown at the top of each column. Negative values indicate a water level decline; positive values indicate water level was rising. N.D. = water level not determined. Dry $=$ water level below bottom of piezometer.

\section{Area 2 - Skellock Draw}

water level change rates in $\mathrm{cm} /$ day

1-Apr-00 30-Apr- 3-Jun- 16-Jun-00 21-Jun-00 12-Jul-00 19-Jul-00

Location Map ID - 30-Apr- 00 - 3- 00 - 16- - 21-Jun- - 12-Jul- - 19-Jul- - 14-

\begin{tabular}{lcccccccc}
\hline \hline Upper Meadow Creek & A & 0.35 & -0.30 & -1.15 & -0.21 & 0.91 & -0.54 & -0.73 \\
Lower Meadow Creek & B & N.D. & N.D. & N.D. & -0.15 & -0.69 & -0.22 & -0.59 \\
Upper Skellock & C & 0.32 & -0.38 & -1.01 & -1.34 & -1.16 & -1.09 & -0.82 \\
Clover Creek Meadow & D & 0.58 & -0.10 & -0.28 & -2.41 & -0.80 & -0.98 & -0.70 \\
Middle Skellock & E & N.D. & -0.30 & -0.38 & -0.09 & -0.51 & -0.33 & -0.35 \\
Skellock arm & F & N.D. & N.D. & N.D. & 1.98 & -1.34 & -0.87 & -0.82 \\
Lower Skellock & G & 0.21 & -0.05 & -0.26 & 0.06 & -0.11 & -0.44 & -0.70 \\
\hline & & $14-$ Aug- & 9-Sep-00 & $21-$-Oct- & $18-$ Nov- & $20-J a n-01$ & $17-$ Mar- & \\
Location & & $00-9-$ & $-21-O c t-$ & $00-18-$ & $00-20-$ & $-17-M a r-$ & $01-27-$ & \\
\hline \hline Upper Meadow Creek & A & -0.50 & -0.36 & -0.14 & N.D. & N.D. & 0.19 & \\
Lower Meadow Creek & B & -0.47 & -0.18 & 0.00 & N.D. & N.D. & 0.11 & \\
Upper Skellock & C & -0.53 & -1.05 & 1.14 & N.D. & N.D. & 0.19 & \\
Clover Creek Meadow & D & -0.29 & -0.09 & 0.14 & N.D. & N.D. & 0.11 & \\
Middle Skellock & E & -0.23 & -0.25 & -0.49 & N.D. & N.D. & 0.00 & \\
Skellock arm & F & -0.32 & -1.00 & 0.00 & N.D. & N.D. & -0.26 & \\
Lower Skellock & G & -0.38 & 0.38 & 0.14 & N.D. & N.D. & -0.04 & \\
\hline
\end{tabular}

Area 3 - Jack Creek

water level change rates in $\mathrm{cm} /$ day

1-Apr-00 30-Apr- 3-Jun- 16-Jun-00 21-Jun-00 12-Jul-00 19-Jul-00

\begin{tabular}{lcccccccc} 
& Map ID $-30-A p r-$ & $00-3-$ & $00-16-$ & $-21-J u n-$ & $-12-J u l-$ & $-19-J u l-$ & $-14-$ \\
Location & 00 & Jun-00 & Jun-00 & 00 & 00 & 00 & Aug-00 \\
\hline \hline
\end{tabular}

\begin{tabular}{|c|c|c|c|c|c|c|c|c|}
\hline Lower Jack Creek & $\mathrm{J}$ & N.D. & N.D. & N.D. & N.D. & N.D. & -1.09 & -1.09 \\
\hline Upper Jack Creek & $\mathrm{K}$ & N.D. & -0.63 & -0.82 & -5.49 & -2.14 & -2.07 & -1.00 \\
\hline Location & Map ID & $\begin{array}{c}\text { 14-Aug- } \\
00-9- \\
\text { Sep-00 }\end{array}$ & $\begin{array}{c}\text { 9-Sep-00 } \\
-21-\text { Oct- } \\
00 \\
\end{array}$ & $\begin{array}{l}21-\text { Oct- } \\
00-18- \\
\text { Nov-00 }\end{array}$ & $\begin{array}{c}\text { 8-Nov-00 } \\
\text { - 20-Jan- } \\
01 \\
\end{array}$ & $\begin{array}{c}\text { 20-Jan-01 } \\
\text { - 17-Mar- } \\
01 \\
\end{array}$ & $\begin{array}{l}\text { 17-Mar- } \\
01 \text { - } 27- \\
\text { Apr-01 }\end{array}$ & \\
\hline Lower Jack Creek & $\mathrm{J}$ & -0.56 & -0.15 & -0.11 & N.D. & N.D. & Dry & \\
\hline Upper Jack Creek & $\mathrm{K}$ & -1.88 & -0.05 & -0.30 & N.D. & N.D. & Dry & \\
\hline
\end{tabular}




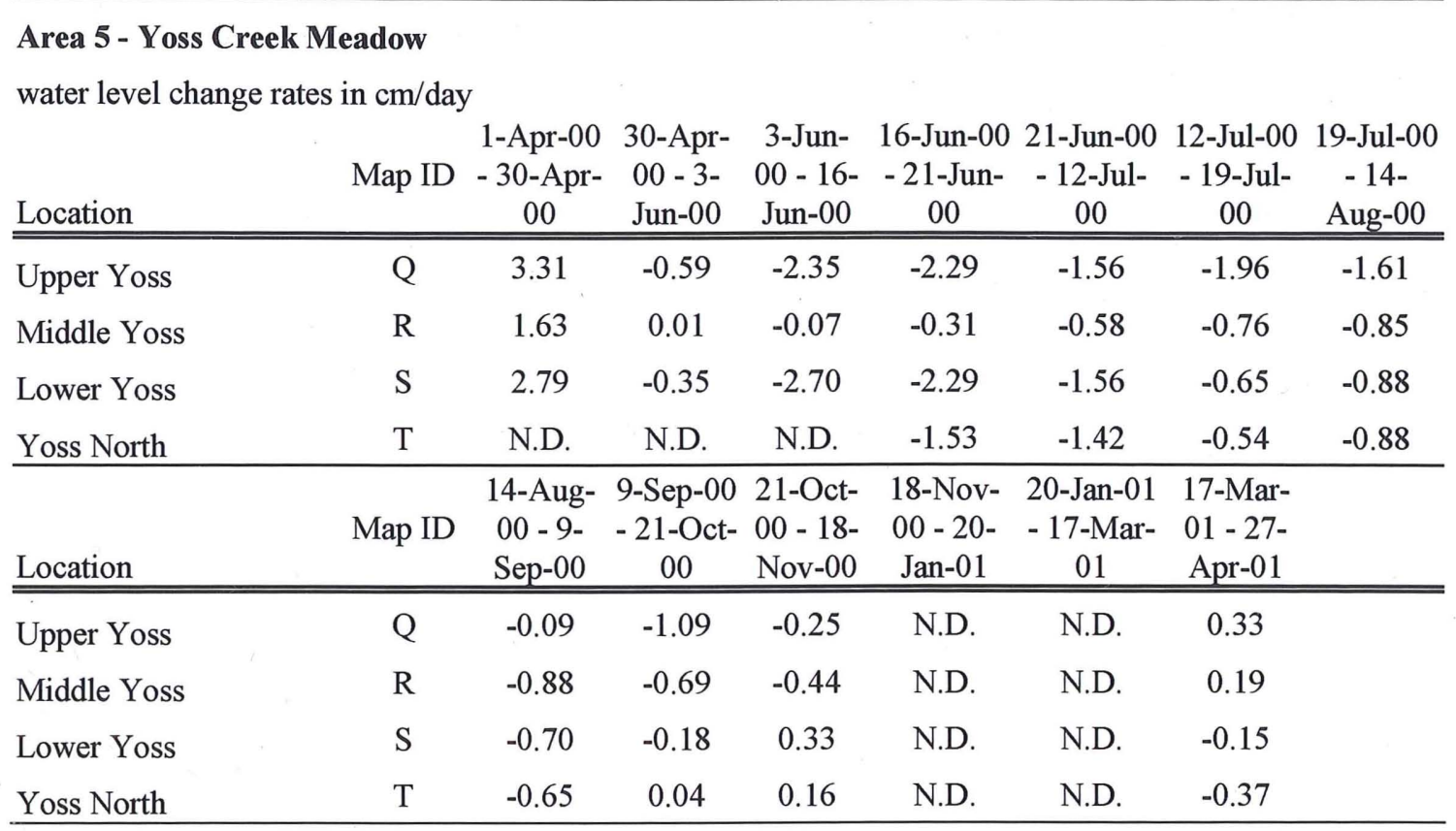

Sugarpine Mountain (Area 3)

Broad basalt shield volcanoes underlie areas north of Klamath Marsh; the highest topographic feature is Sugarpine Mountain. The reconnaissance geologic observations, topography, and degree of incision of streams (God, Mosquito, Jack, and Three Creeks) suggest this area is underlain by shield volcanoes of different ages. Basalt flows directly overlie pyroclastic flows of Pliocene age at the north edge of the Wildhorse Ridge quadrangle (Cummings et al., in review), but how far north these Pliocene rocks extend is not known. Geologic information from water well logs indicates aquifers in interflow zones of basalt flows (burnt lava, Table 16). Relatively high recharge volume (Figure 16) indicate high potential recharge for aquifers.

As mentioned in the previous section, piezometers were installed is Skellock Draw in Area 2, Jack Creek in Area 3, and Yoss Creek Meadow in Area 5 to monitor water drainage patterns in perched aquifers in pyroclastic material to elicit information on 
infiltration into underlying bedrock surfaces. Piezometers in pyroclastic air-fall deposits flanking Jack Creek, showed the greatest rate of water level decline $(5.49 \mathrm{~cm} /$ day, Table 15) within monitored basins, ranging from 5.49 to $0.03 \mathrm{~cm} /$ day (Table 15) with a mean of $1.24 \mathrm{~cm} /$ day. Thin, vesicular basalt flows in outcrops near Jack Creek are assumed to underlie the pumice filled paleovalleys, providing ample pathways for infiltration.

Relatively high rates of decline in piezometers are consistent with this interpretation.

Table 16 - Summary of recharge, geology and water well yields in Area 3.

\begin{tabular}{|c|c|c|c|}
\hline $\begin{array}{c}\text { Mean } \\
\text { Precipitation }\end{array}$ & $\begin{array}{l}\text { Precipitation } \\
\text { Volume }\end{array}$ & Evapotranspiration Volume & Recharge Volume \\
\hline $71.7 \mathrm{~cm}$ & 489 million $\mathrm{m}^{3}$ & 132 million to 231 million $\mathrm{m}^{3}$ & 258 million to 357 million $\mathrm{m}^{3}$ \\
\hline \multicolumn{4}{|c|}{$\begin{array}{l}\text { Geologic Summary: } \\
\text { The geology in Area } 3 \text {, surrounding Sugarpine Mountain has not been mapped; however, reconnaissance } \\
\text { examination was conducted in this study. Sugarpine Mountain is built on broad basaltic shields that mark } \\
\text { the northern extent of Klamath Marsh. The western extent of these basalt shields is cut by the WRMC } \\
\text { fault zone with at least } 30 \text { m of displacement. Outcrops near Jack Creek indicate the basalt flows are thin } \\
\text { (1-3 m) and vesicular. Surface deposits are dominated by pyroclastic-fall material from the climactic } \\
\text { eruption of Mount Mazama. }\end{array}$} \\
\hline \multicolumn{4}{|c|}{ Well Yields: (Average yield = 188 gpm) } \\
\hline \multicolumn{2}{|c|}{ OWRD well log \# (Figure 20) } & Pump test yield & Water-bearing unit \\
\hline \multicolumn{2}{|c|}{$\begin{array}{l}\text { Klam } 11773 \\
\text { Depth }=380^{\prime}\end{array}$} & $\begin{array}{c}250 \text { gpm with } 0 \text { ' drawdown after } \\
3 \text { hours }\end{array}$ & "Burnt" lava and lava rock \\
\hline \multicolumn{2}{|c|}{$\begin{array}{l}\text { Klam 52531 } \\
\text { Depth }=203\end{array}$} & 100 gpm (airlift test) & Medium gray lava \\
\hline \multicolumn{2}{|c|}{$\begin{array}{l}\text { Klam } 11772 \\
\text { Depth }=171\end{array}$} & 150 gpm (airlift test) & $\begin{array}{c}\text { Brown, black, and red lava } \\
\text { rock }\end{array}$ \\
\hline \multicolumn{2}{|c|}{$\begin{array}{c}\text { Klam } 562 \\
\text { Depth }=407\end{array}$} & 250 gpm (drawdown unknown) & "Burnt" lava and boulders \\
\hline
\end{tabular}

Additional information is available for each well in Appendix B. 
Antelope Desert (Area 4)

The bedrock geology beneath the Antelope Desert is interpreted from water well logs (Table 17) that indicate volcaniclastic sedimentary rocks interbedded with lava flows. Some of the sedimentary rocks are described as unlithified and some lava flows are fractured increasing permeability. Yields from pump tests during well construction are relatively high (average yield $=650 \mathrm{gpm}$, Table 17 ). The geology underlying the Cascades was not examined by this study and information is limited in water-well logs. Sherrod and Pickthorn (1992) indicate the area is underlain by Pleistocene andesite, basaltic andesite, dacite, rhyolite, and rhyodacite volcanic rocks.

Because of its proximity to the Cascade Crest sub-region, recharge to aquifers (Table 17) in this area is assumed to be the combination of the recharge from the Cascade Crest and the Antelope Desert. This combined volume ranks the highest among the five areas, with up to 998 million $\mathrm{m}^{3}\left(743\right.$ million +245 million $\left.\mathrm{m}^{3}\right)$ of water potentially available for recharge. This area appears to display the highest permeability in geologic material and displays highest recharge potential. 
Table 17 - Summary of recharge, geology and water well yields in Area 4.

\begin{tabular}{|c|c|c|c|}
\hline \multicolumn{4}{|l|}{ Cascade Crest } \\
\hline $\begin{array}{c}\text { Mean } \\
\text { Precipitation }\end{array}$ & $\begin{array}{l}\text { Precipitation } \\
\text { Volume }\end{array}$ & Evapotranspiration & Recharge Volume \\
\hline $107.8 \mathrm{~cm}$ & 831 million $\mathrm{m}^{3}$ & 88 million to 154 million $\mathrm{m}^{3}$ & 677 million to 743 million $\mathrm{m}^{3}$ \\
\hline \multicolumn{4}{|c|}{ Antelope Desert } \\
\hline $\begin{array}{c}\text { Mean } \\
\text { Precipitation }\end{array}$ & $\begin{array}{l}\text { Precipitation } \\
\text { Volume }\end{array}$ & Evapotranspiration & Recharge Volume \\
\hline $55.7 \mathrm{~cm}$ & 591 million $\mathrm{m}^{3}$ & 346 million to 605 million $\mathrm{m}^{3}$ & -14 million to 245 million $\mathrm{m}^{3}$ \\
\hline \multicolumn{4}{|c|}{$\begin{array}{l}\text { Geologic Summary: } \\
\text { The geology from Klamath Marsh to the foothills of the Cascades is known only from driller's logs for } \\
\text { water wells. Geologic logs indicate varying degrees of consolidation and thickness of sand, gravel, and } \\
\text { clay, interbedded with fractured and unfractured lava flows. This area lies in the downthrown block of } \\
\text { the WRMC fault zone. The deepest well (Klam } 693 ; 195 \mathrm{~m}) \text { penetrated interbedded sand, clay, and loose } \\
\text { lava rock. Capping these materials northwest of Klamath Marsh is a thin }(\sim 4 \mathrm{~m}) \text { basalt flow with a } \\
\text { characteristic diktytaxitic texture (Melady and Cummings, in preparation). Surface units are primarily } \\
\text { pyroclastic-flow deposits from Mount Mazama, with areas below } 1402 \mathrm{~m} \text { underlain by reworked } \\
\text { deposits. }\end{array}$} \\
\hline \multicolumn{4}{|c|}{ Well Yields (This in only a partial list, average yield based on total of 51 wells $=650 \mathrm{gpm}$ ) } \\
\hline \multicolumn{2}{|c|}{ OWRD well log \# (Figure 20) } & Pump test yield & Water bearing unit \\
\hline \multicolumn{2}{|c|}{$\begin{array}{l}\text { Klam } 10819 \\
\text { Depth }=75\end{array}$} & $\begin{array}{c}75 \text { gpm with 0' drawdown after } \\
1 \text { hour }\end{array}$ & Fine gravel and sand \\
\hline \multicolumn{2}{|c|}{$\begin{array}{c}\text { Klam } 666 \\
\text { Depth }=462\end{array}$} & $120 \mathrm{gpm}$ artesian flow & Sand, gravel, pumice, and clay \\
\hline \multicolumn{2}{|c|}{$\begin{array}{c}\text { Klam } 667 \\
\text { Depth }=131\end{array}$} & $12.5 \mathrm{gpm}$ artesian flow & Sand and gravel \\
\hline \multicolumn{2}{|c|}{$\begin{array}{l}\text { Klam } 11785 \\
\text { Depth }=340^{\prime}\end{array}$} & $\begin{array}{c}4000 \text { gpm with } 79^{\prime} \text { drawdown } \\
\text { after } 4 \text { hours }\end{array}$ & $\begin{array}{c}\text { Sand, gravel,'boulders, and } \\
\text { lava }\end{array}$ \\
\hline \multicolumn{2}{|c|}{$\begin{array}{c}\text { Klam 670 } \\
\text { Depth }=274\end{array}$} & $\begin{array}{c}3500 \text { gpm with } 55^{\prime} \text { drawdown } \\
\text { after } 3 \text { hours }\end{array}$ & Brown and grey lava \\
\hline \multicolumn{2}{|c|}{$\begin{array}{l}\text { Klam 50590 } \\
\text { Depth }=452^{\prime}\end{array}$} & $\begin{array}{c}3200 \text { gpm with } 12 \text { ' drawdown } \\
\text { after } 7 \text { hours }\end{array}$ & Gray lava and black sand \\
\hline \multicolumn{2}{|c|}{$\begin{array}{l}\text { Klam } 11478 \\
\text { Depth }=498\end{array}$} & $\begin{array}{l}2050 \text { gpm with } 117 \text { ' drawdown } \\
\text { after } 8 \text { hours }\end{array}$ & $\begin{array}{c}\text { Gray and brown basalt, } \\
\text { broken }\end{array}$ \\
\hline \multicolumn{2}{|c|}{$\begin{array}{l}\text { Klam } 10202 \\
\text { Depth }=300^{\prime}\end{array}$} & $\begin{array}{l}4000 \text { gpm with } 41 \text { ' drawdown } \\
\text { after } 1 \text { hour }\end{array}$ & Gray and black lava \\
\hline
\end{tabular}

Additional information is available for each well in Appendix B.

Williamson River Canyon (Area 5)

The geology of Area 5 is the most diverse. Relatively low permeability Pliocene

basalt hydrovolcanic deposits are exposed in the Williamson River Canyon and are 
present for at least $1.5 \mathrm{~km}$ west and $5 \mathrm{~km}$ east of the canyon (Lee and Cummings, in press). These are locally overlain by early Pleistocene basalt flows. Sixty (60) $\mathrm{m}$ of fluvial and lacustrine deposits are overlain by basaltic andesite lava flows west of the canyon. These lava flows appear to be part of a NNW trending flow field that extends toward Crater Lake. Area 5 is characterized by abundant normal faulting that may increase secondary permeability. Water wells in the area indicate moderate to high yields in some areas (Klam 713, Figure 20), with low yields (Klam 714, 758, 757, Figure 20) in other areas. This is consistent with areas of increased secondary permeability near faults (high yields), with permeability decreasing with distance, decreasing potential yields. Aquifer materials indicate possible sediment accumulation in grabens between bounding faults, which may have high permeablilty. Recharge is this area is relatively low (Table 18), ranking fifth among the six sub-areas.

Piezometers installed in Yoss Creek Meadow in Area 5 provide relative comparison of infiltration into bedrock under reworked and pyroclastic-fall materials. Yoss Creek Meadow is a pumice filled wetland located in a fault bounded valley believed to be underlain by two Pliocene basaltic andesite flows (Conaway and Cummings, in press). Yoss Creek drains Yoss Creek Meadow, but flow during this study period only occurred in the upper reaches of the meadow, before sinking into the pumice. Four piezometers were installed and discharge on Yoss Creek was monitored to examine water movement in the pyroclastic material filling the valley. The piezometer located in the upper Yoss Meadow showed the highest rate of water level increase (1-April-00 - 30-April-00, $3.31 \mathrm{~cm} \mathrm{day}^{-1}$, Table 15) noted throughout this 
study. This period also coincided with the largest increase in discharge in nearby Yoss

Creek (1-April-00, $0.005 \mathrm{~m}^{3} \mathrm{~s}^{-1}-30$-April-00, $0.025 \mathrm{~m}^{3} \mathrm{~s}^{-1}$, Table 24). Rates of decline

in piezometers ranged from $2.70-0.09 \mathrm{~cm} \mathrm{day}^{-1}$ (Table 15) with a mean of $0.98 \mathrm{~cm}$

day $^{-1}$. These values fall between rates of decline in Skellock Draw and Jack Creek.

This likely indicates that Yoss Meadow is underlain by material with infiltration rates

between those found in Skellock Draw and Jack Creek, probably faulted and fractured

basaltic andesite.

Table 18 - Summary of recharge, geology and water well yields in Area 5.

\begin{tabular}{|c|c|c|c|}
\hline $\begin{array}{c}\text { Mean } \\
\text { Precipitation }\end{array}$ & $\begin{array}{c}\text { Precipitation } \\
\text { Volume }\end{array}$ & Evapotranspiration Volume & Recharge Volume \\
\hline $55.4 \mathrm{~cm}$ & 257 million $\mathrm{m}^{3}$ & 168 million to 294 million $\mathrm{m}^{3}$ & -37 million to 89 million $\mathrm{m}^{3}$ \\
\hline
\end{tabular}

Geologic Summary:

The geology of two quadrangles in Area 5 were mapped by Conaway and Cummings (in press) and Lee and Cummings (in press), material herein is a synthesis from these studies. The tuff of Skellock Draw is present on the eastern side of this area and is overlain by basaltic andesite flows. The central section is comprised of basaltic andesite erupted from Soloman Butte and several other small local volcanic centers overlain in areas by high alumina olivine thoeliitic basalt. On the western side of Area 5, approximately $60 \mathrm{~m}$ of alluvial and lacustrine sedimentary rock is underlain by hydrovolcanics and basalt flows exposed in the Williamson River Canyon. A dominant feature of this area is the presence of northwest striking normal faults. Surficial deposits in topographically low areas are dominated by pyroclastic-flow materials from the climactic eruption of Mount Mazama, with areas below $1402 \mathrm{~m}$ reworked by the wave action of the backflooded Klamath Marsh. Surface deposits in topographically high areas are dominated by pyroclastic-fall deposits from the eruptions of Mount Mazama.

\begin{tabular}{|c|c|c|}
\hline \multicolumn{3}{|c|}{ Well Yields (Average yield $=557 \mathrm{gpm}$ ) } \\
\hline OWRD well $\log \#$ (Figure 20) & Pump test yield & Water bearing unit \\
\hline $\begin{array}{c}\text { Klam } 713 \\
\text { Depth }=105\end{array}$ & $\begin{array}{l}1950 \text { gpm with } 29 \text { ' drawdown } \\
\text { after } 2 \text { hours }\end{array}$ & Lava, sand, and gravel \\
\hline $\begin{array}{c}\text { Klam } 715 \\
\text { Depth }=301\end{array}$ & $\begin{array}{c}775 \text { gpm with 95' drawdown } \\
\text { after } 4 \text { hours }\end{array}$ & Sand and gravel \\
\hline $\begin{array}{c}\text { Klam } 714 \\
\text { Depth }=300\end{array}$ & $\begin{array}{c}20 \text { gpm with 49' drawdown after } \\
1 \text { hour }\end{array}$ & Lava rock \\
\hline $\begin{array}{c}\text { Klam } 758 \\
\text { Depth }=265\end{array}$ & $\begin{array}{c}20 \text { gpm with } 65^{\prime} \text { drawdown after } \\
1 \text { hour }\end{array}$ & Black and brown lava rock \\
\hline $\begin{array}{c}\text { Klam } 757 \\
\text { Depth }=355\end{array}$ & 20 gpm (airlift test) & Unknown \\
\hline
\end{tabular}

Additional information is available for each well in Appendix B. 


\section{Hydrogeologic Observations}

Hydrogeology can be described as the relationship that exists between the geology, surface water, and groundwater in the area of interest. This section presents water levels from near surface piezometers, discharge data for eleven streams or rivers, and deuterium and oxygen isotope data used to trace water sources in the Williamson River basin during 2000-2001.

\section{Methods}

Groundwater Level Measurment:

Twenty near surface piezometers (depth range 1-3 m) were installed at various locations near Klamath Marsh. Hand augered holes were drilled in chosen sites and PVC pipes were inserted, noting the total pipe length and the distance from the top of the pipe to the ground surface. Depth to water surface was measured at each piezometer at various times between April, 2000 and April, 2001 with a Fisher water level indicator.

\section{Surface Water Discharge:}

Surface water discharge was calculated for 13 locations at various times between April, 2000 and April, 2001. Discharge was calculated at each location by measurement of water velocity with a Swoffer hand-held current velocity meter and depth at regular intervals across the stream, measurements were input into the following equation:

$$
Q=\sum V_{i} \times W_{i} \times D_{i}
$$

Where $\mathrm{Q}$ is Discharge (volume/time), $\mathrm{V}_{\mathrm{i}}$ is the water velocity in the interval (length/time), $\mathrm{W}_{\mathrm{i}}$ is the width of the interval (length), and $\mathrm{D}_{\mathrm{i}}$ is the water depth in the interval (length). 
Groundwater levels

Piezometers were placed in locations (Figure 21) where groundwater levels were interpreted to be within pyroclastic deposits from Mount Mazama, where hydrogeologic parameters for bedrock units were desired, and where near surface water levels were believed to represent the regional water table. From the data obtained through field measurements (Table 19), the daily rate of decline of water levels between measurements were estimated. Rates of water level change in piezometers in Skellock

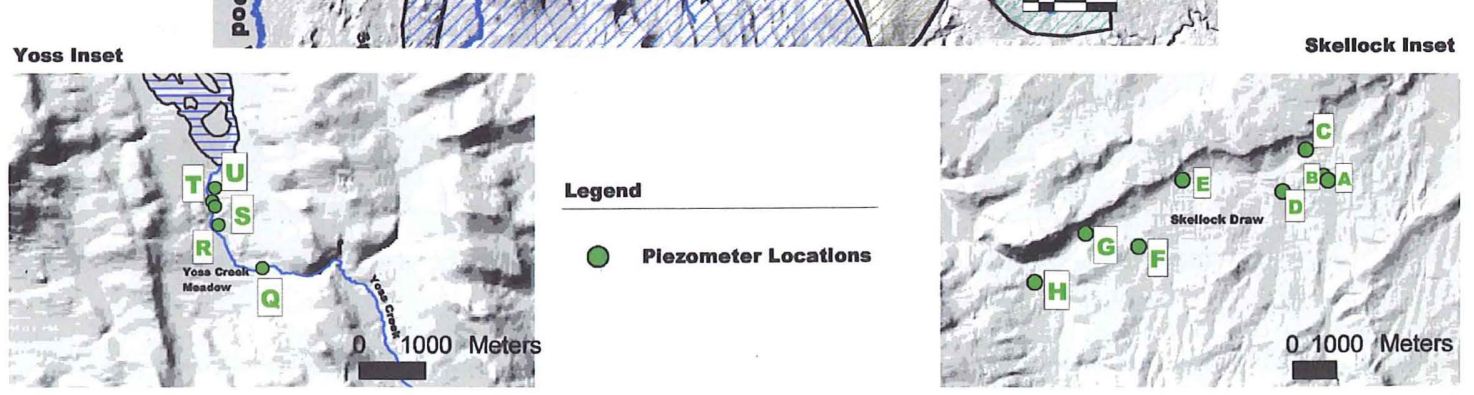

Figure 21 -Location of piezometers monitored by this study. Identification letters in green are keyed to piezometer measurements in Table 19. 
Table 19 - Water level below local ground surface in piezometers installed and monitored during 2000-2001. Map ID indicates location of piezometers keyed to Figure 21. Negative values indicate water level above ground surface. (N.D. $=$ water level not determined).

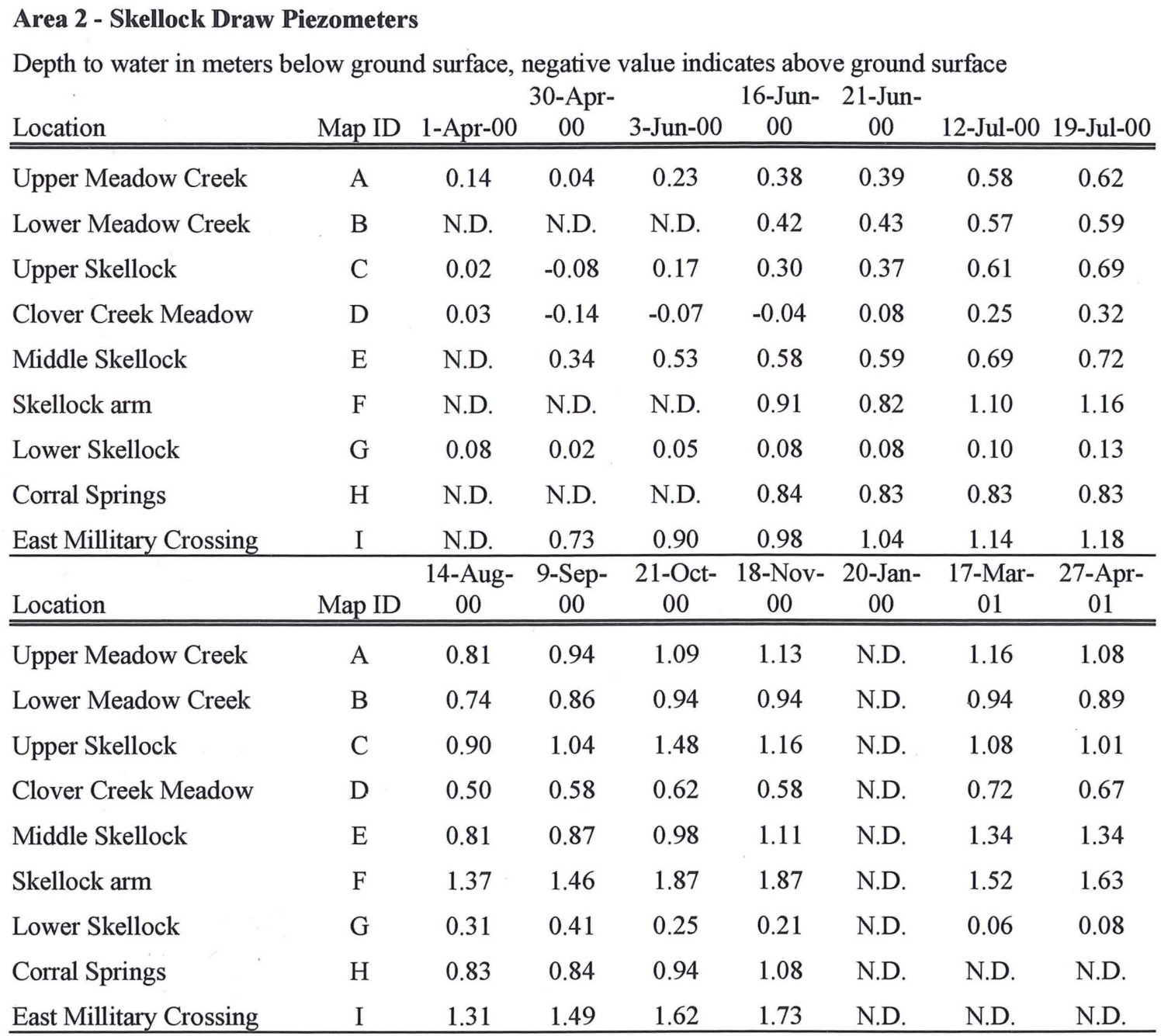

\section{Area 3 - Sugarpine Mountain Piezometers}

Depth to water in meters below ground surface, negative value indicates above ground surface

\begin{tabular}{lcccccccc} 
Location & \multicolumn{2}{c}{$30-$ Apr- } & \multicolumn{1}{c}{ 16-Jun- } & 21-Jun- \\
\hline \hline Lower Jack Creek & Map ID & 1-Apr-00 & 00 & 3-Jun-00 & 00 & 00 & 11-Jul-00 & 19-Jul-00 \\
Upper Jack Creek & $\mathrm{J}$ & N.D. & N.D. & N.D. & N.D. & N.D. & 0.05 & 0.13 \\
Mosquito Creek & $\mathrm{K}$ & N.D. & -0.02 & 0.40 & 0.50 & 0.78 & 1.23 & 1.37 \\
God Creek & $\mathrm{L}$ & N.D. & N.D. & N.D. & N.D. & N.D. & 0.16 & 0.19 \\
\hline \multirow{2}{*}{ Location } & $\mathrm{M}$ & N.D. & N.D. & N.D. & N.D. & 1.06 & 1.49 & 1.62 \\
\hline \hline
\end{tabular}




\begin{tabular}{lcccccccc} 
Lower Jack Creek & $\mathrm{J}$ & 0.41 & 0.56 & 0.62 & 0.65 & N.D. & N.D. & Dry \\
Upper Jack Creek & $\mathrm{K}$ & 1.63 & 2.12 & 2.14 & 2.23 & N.D. & N.D. & Dry \\
Mosquito Creek & $\mathrm{L}$ & 0.47 & 0.71 & 0.80 & 0.81 & N.D. & N.D. & N.D. \\
God Creek & $\mathrm{M}$ & 1.73 & N.D. & N.D. & N.D. & N.D. & N.D. & N.D. \\
\hline
\end{tabular}

Area 4 - Pumice Plain Piezometers

Depth to water in meters below ground surface, negative value indicates above ground surface

\begin{tabular}{|c|c|c|c|c|c|c|c|c|}
\hline & & & 30-Apr- & & 16-Jun- & 21-Jun- & & \\
\hline Location & Map ID & 1-Apr-00 & 00 & 3-Jun-00 & 00 & 00 & 12-Jul-00 & 19-Jul-00 \\
\hline $3 \mathrm{CR}$ & $\mathrm{N}$ & N.D. & N.D. & N.D. & 0.39 & 0.36 & 0.42 & 0.47 \\
\hline MXR Quarry & $\mathrm{O}$ & N.D. & N.D. & N.D. & N.D. & N.D. & N.D. & 1.28 \\
\hline Big Springs & $\mathrm{P}$ & N.D. & N.D. & N.D. & 0.37 & 0.38 & 0.41 & 0.43 \\
\hline Location & Map ID & $\begin{array}{c}\text { 14-Aug- } \\
00\end{array}$ & $\begin{array}{c}\text { 9-Sep- } \\
00 \\
\end{array}$ & $\begin{array}{c}21-\text { Oct- } \\
00 \\
\end{array}$ & $\begin{array}{c}\text { 18-Nov- } \\
00 \\
\end{array}$ & $\begin{array}{c}\text { 20-Jan- } \\
01 \\
\end{array}$ & $\begin{array}{c}\text { 17-Mar- } \\
01\end{array}$ & $\begin{array}{c}\text { 27-Apr- } \\
01\end{array}$ \\
\hline $3 \mathrm{CR}$ & $\mathrm{N}$ & 0.59 & 0.65 & 0.70 & 0.75 & N.D. & N.D. & 0.98 \\
\hline MXR Quarry & $\mathrm{O}$ & 1.25 & 1.28 & 1.33 & 1.36 & N.D. & 1.52 & 1.60 \\
\hline Big Springs & $\mathrm{P}$ & 0.47 & 0.46 & 0.46 & 0.47 & N.D. & 0.43 & 0.49 \\
\hline
\end{tabular}

Area 5 - Lower Williamson River Piezometers

Depth to water in meters below ground surface, negative value indicates above ground surface

\begin{tabular}{|c|c|c|c|c|c|c|c|c|}
\hline Location & Map ID & 1-Apr-00 & $\begin{array}{c}\text { 30-Apr- } \\
00 \\
\end{array}$ & 3-Jun-00 & $\begin{array}{c}\text { 16-Jun- } \\
00 \\
\end{array}$ & $\begin{array}{c}21-J u n- \\
00 \\
\end{array}$ & 12-Jul-00 & 19-Jul-00 \\
\hline & & & & \multicolumn{5}{|c|}{1} \\
\hline Upper Yoss & Q & 1.50 & 0.54 & 0.92 & 1.23 & 3 & 1.67 & 1.81 \\
\hline Middle Yoss & $\mathrm{R}$ & 0.44 & -0.03 & -0.04 & -0.03 & -0.02 & 0.11 & 0.16 \\
\hline Lower Yoss & $\mathrm{S}$ & 0.72 & -0.09 & 0.14 & 0.49 & 0.60 & 0.93 & 0.98 \\
\hline Yoss North & $\mathrm{T}$ & N.D. & N.D. & N.D. & 0.96 & 1.04 & 1.33 & 1.37 \\
\hline Yoss Quarry & $\mathrm{U}$ & 0.32 & 0.26 & 0.29 & 0.49 & 0.55 & 0.82 & 0.88 \\
\hline Hog Creek & $\mathrm{V}$ & N.D. & N.D. & N.D. & N.D. & N.D. & N.D. & N.D. \\
\hline Location & Map ID & $\begin{array}{c}14-\text { Aug- } \\
00 \\
\end{array}$ & $\begin{array}{c}\text { 9-Sep- } \\
00 \\
\end{array}$ & $\begin{array}{c}21-O c t- \\
00 \\
\end{array}$ & $\begin{array}{c}\text { 18-Nov- } \\
00 \\
\end{array}$ & $\begin{array}{c}20-J a n- \\
01 \\
\end{array}$ & $\begin{array}{c}\text { 17-Mar- } \\
01 \\
\end{array}$ & $\begin{array}{c}\text { 27-Apr- } \\
01 \\
\end{array}$ \\
\hline Upper Yoss & Q & 2.23 & 2.25 & 2.71 & 2.77 & N.D. & 2.97 & 2.83 \\
\hline Middle Yoss & $\mathrm{R}$ & 0.38 & 0.61 & 0.90 & 1.02 & N.D. & 1.30 & 1.22 \\
\hline Lower Yoss & $\mathrm{S}$ & 1.20 & 1.39 & 1.46 & 1.37 & N.D. & 1.30 & 1.36 \\
\hline Yoss North & $\mathrm{T}$ & 1.60 & 1.77 & 1.75 & 1.71 & N.D. & 1.54 & 1.69 \\
\hline Yoss Quarry & $\mathrm{U}$ & 1.07 & 1.22 & 1.10 & 1.02 & N.D. & 0.64 & 0.78 \\
\hline Hog Creek & $\mathrm{V}$ & 0.15 & N.D. & N.D. & N.D. & N.D. & N.D. & N.D. \\
\hline
\end{tabular}

Draw in Area 2, Jack Creek in Area 3, and Yoss Creek Meadow in Area 5 were

discussed in a previous section. Here, data for two piezometers and a small quarry pond 
in Area 4 and northwest of Klamath Marsh are reported (Table 20). Water levels in 3CR piezometer, Big Springs piezometer, and MXR quarry pond showed the lowest rates of decline $\left(0.00-0.76 \mathrm{~cm}^{\text {day }}{ }^{-1}\right.$, mean $=0.20 \mathrm{~cm}$ day $\left.{ }^{-1}\right)$ among all areas. Water wells near these piezometers indicate the regional water table approaches the ground surface and at times artesian flow has been present. Three wells near Big Springs

Table 20 - Rate of water level change in Area 4 - Antelope Desert piezometers in $\mathrm{cm}$ day $^{-1}$. Map ID keyed to location on Figure 21. (N.D. $=$ water level not determined)

\section{Area 4 - Antelope Desert}

Piezometer rate of change in $\mathrm{cm} \mathrm{day}^{-1}$

\begin{tabular}{lcccccccc} 
& Map & 1-Apr-00 - & 30-Apr-00 & 3-Jun-00 - & 16-Jun-00 - & 21-Jun-00 - & 12-Jul-00 - & 19-Jul-00 - \\
Location & ID & 30-Apr-00 & - 3-Jun-00 & 16-Jun-00 & 21-Jun-00 & 12-Jul-00 & 19-Jul-00 & 14-Aug-00 \\
\hline \hline 3CR & N & N.D. & N.D. & N.D. & 0.67 & -0.29 & -0.76 & -0.47 \\
MXR Quarry & O & N.D. & N.D. & N.D. & N.D. & N.D. & N.D. & 0.12 \\
Big Springs & P & N.D. & N.D. & N.D. & -0.15 & -0.15 & -0.22 & -0.18 \\
\hline
\end{tabular}

14-Aug-00 9-Sep-00 - 21-Oct-00 - 18-Nov-00 20-Jan-01 - 17-Mar-01

- 9-Sep-00 21-Oct-00 18-Nov-00 - 20-Jan-01 17-Mar-01 -27-Apri-01

\begin{tabular}{llllllll}
\hline \hline 3CR & $\mathrm{N}$ & -0.21 & -0.13 & -0.19 & N.D. & N.D. & N.D. \\
MXR Quarry & $\mathrm{O}$ & -0.12 & -0.11 & -0.11 & N.D. & N.D. & -0.19 \\
Big Springs & $\mathrm{P}$ & 0.06 & 0.00 & -0.05 & N.D. & N.D. & -0.15 \\
\hline
\end{tabular}

(Klam 10819, Klam 11478, and Klam 10202, Figure 20) indicate static water levels

from 2.4 to $3.2 \mathrm{~m}$ ( 8 to $10.5 \mathrm{ft}$ ) below ground surface between 1990 - 1995. Water well

Klam 11478 and Klam 10202 have completed depths of 152 m and 91 m, respectively.

Water wells Klam 666 (completed depth $=141 \mathrm{~m})$ and Klam $667($ completed depth $=40$

m), also located near Big Springs (Figure 20), maintained artesian flow between 1961 -

1967 based on water well reports (Appendix B).

Water levels in these water wells historically have shown that the regional water table resides at or near the ground surface in this portion of Area 4 and probably indicate 
that the water levels in the piezometers are representative of the regional water table. Based on the depth of the regional water table in this area, Big Springs is believed to be a discharge point for groundwater in the aquifer tapped by these water wells mentioned above. Discharge on Big Springs Creek, which flows from Big Springs, is believed to fluctuate with water levels in this aquifer underlying Area 4. Figure 22 shows discharge on Big Springs Creek (USGS gaging station \#11492400) during the gaging station operation period from May 1992 to September 1995. Big Springs Creek had a peak discharge over this period on March 21, 1993 of $2.69 \mathrm{~m}^{3} \mathrm{sec}^{-1}$ and had zero discharge from 10-Dec-1992 to 14-Mar-1993, 19-June-1994 to1-Dec-1994, and 14-July-1995 to at least 30-Sept-1995. In the six months prior to the peak discharge, precipitation was significantly higher (Figure 22) than mean monthly precipitation over that period, and may suggest precipitation recharges the aquifer, increasing groundwater levels and flow from Big Springs. Alternatively and more likely, the timing of the peak discharge coincided with peak snowmelt and is likely the source for the elevated discharge. Conversely, periods of no flow appear to follow several months of below normal precipitation (Figure 22) and may indicate that lower recharge to the aquifer drops groundwater levels below Big Springs, causing flow to cease. 


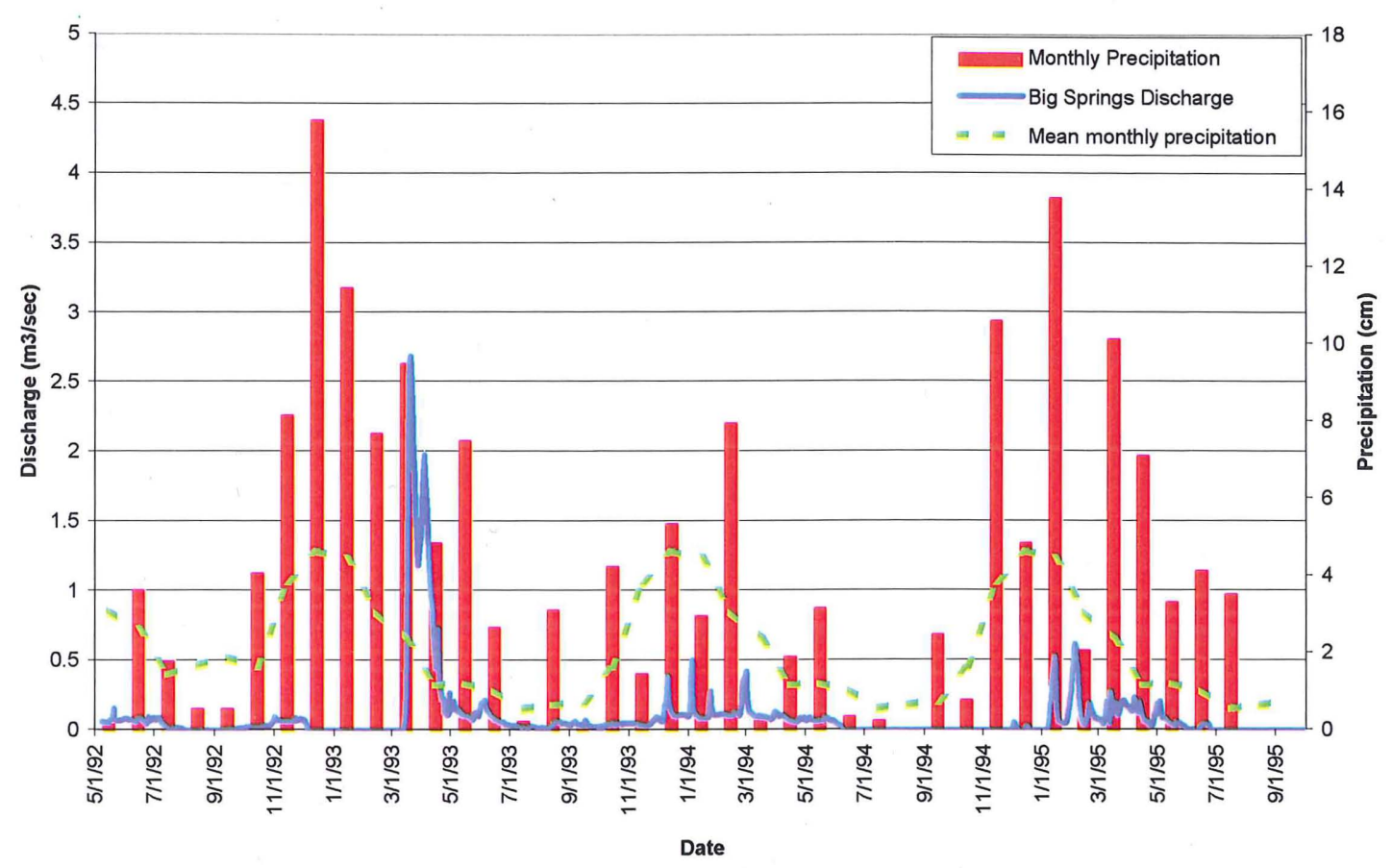

Figure 22 - Discharge over the period of operation (5/1992 - 9/1995) of USGS gaging station \# 11492400 on Big Springs Creek (USGS, 2000) with measured monthly and mean monthly precipitation at Chiloquin (USDA, 2000).

\section{Surface Water}

The headwaters of the Williamson River lie at a group of springs at the southern flank of Yamsay Mountain. Springs and streams discharging from the western flank of Yamsay Mountain contribute to the flow of the Williamson River along its course in Area 1 (Figure 23). From south to north: Sand, Deep, Aspen, Sheep, Modoc, Hoyt, and Jackson Creeks empty onto pyroclastic and alluvial deposits flanking the Williamson 
River. An intermittently operated USGS gaging station (gaging station \#11491400)

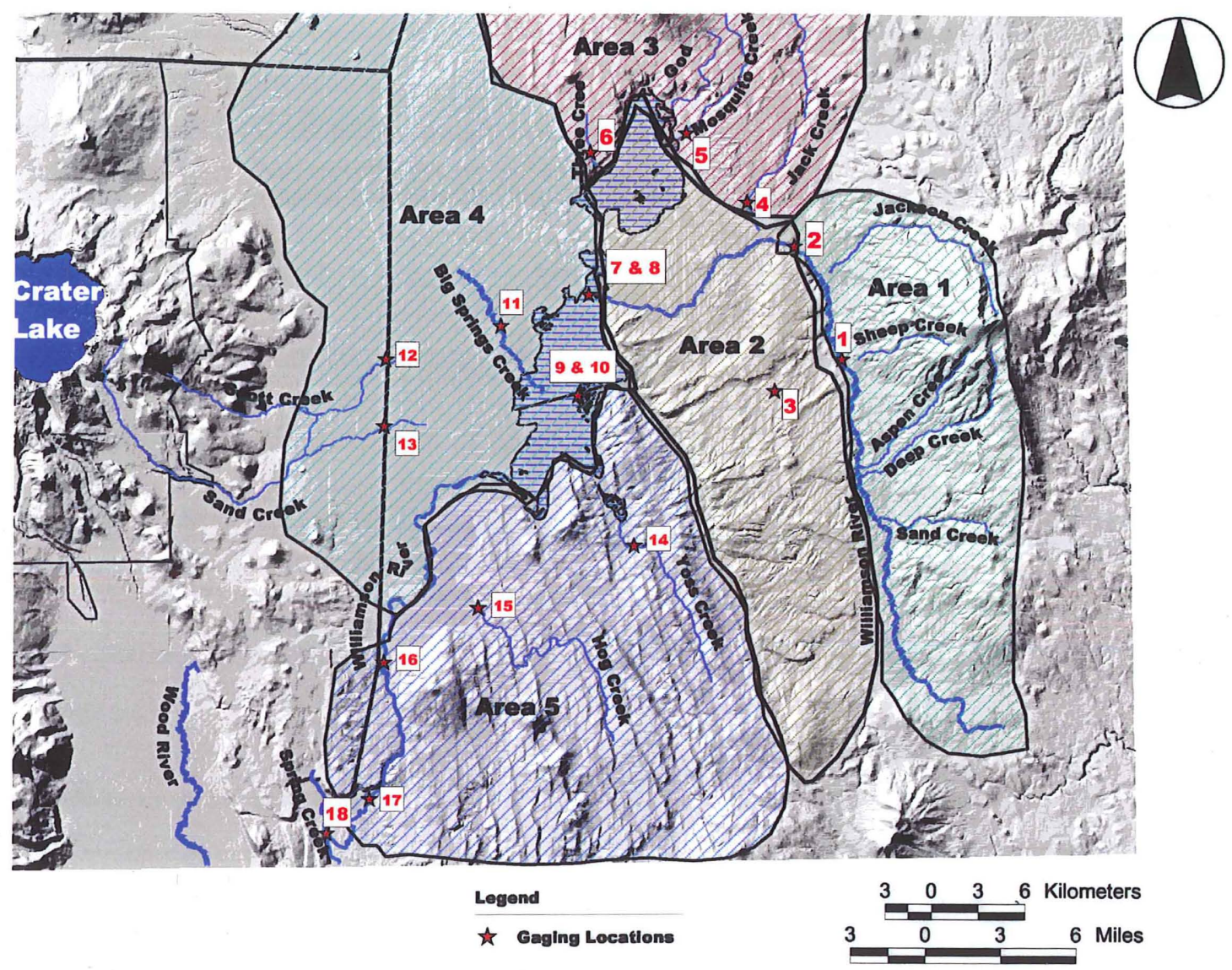

Figure 23 - Gaging locations monitored by this study. Identification numbers in red are keyed to discharge Tables 21, 22, 23, 24 and water level Table 25.

and, in this study, a gaging point at a privately owned foot bridge were used to monitor discharge on the Williamson River in Area 1 (Table 21).

Table 21 - Discharge $\left(\mathrm{m}^{3} \mathrm{~s}^{-1}\right)$ measurements in Area 1 - Upper Williamson River from 2000-2001 (N.D. $=$ Discharge Not Determined). Location of gaging point is Map ID keyed toFigure 23.

Area 1 - Upper Williamson Discharge

Discharge $\left(\mathrm{m}^{3} \mathrm{~s}^{-1}\right)$

1-Apr- 30-Apr- 3-Jun- 16-Jun- 21-Jun- 12-Jul- 19 -

\begin{tabular}{lcccccccc} 
Location & Map ID & 00 & 00 & 00 & 00 & 00 & 00 & Jul-00 \\
\hline \hline USGS Gaging Station \# 11491400 & 1 & N.D. & 2.66 & N.D. & N.D. & N.D. & N.D. & N.D. \\
Upper Williamson at Foot Bridge & 2 & N.D. & 3.68 & 2.50 & 2.10 & 1.96 & 1.70 & 1.75 \\
\hline
\end{tabular}




\begin{tabular}{lllllllll}
\hline USGS Gaging Station \# 11491400 & 1 & N.D. & N.D. & N.D. & N.D. & N.D. & N.D. & N.D. \\
Upper Williamson at Foot Bridge & 2 & 1.61 & 1.74 & 1.80 & 1.86 & N.D. & N.D. & 1.11 \\
\hline
\end{tabular}

After flowing north for approximately $37 \mathrm{~km}$, the Williamson River bends to the west and through Area 2 (discharge in Area 2 in Table 22). Jack Creek discharges toward the Williamson River from Area 3, with additional streams in Area 3 (Table 22) flowing into the northern section of Klamath Marsh.

Table 22 - Discharge $\left(\mathrm{m}^{3} \mathrm{~s}^{-1}\right)$ measurements in Area 2 - Skellock Upland and Area 3 Sugarpine Mountain during 2000-2001 (N.D. = Discharge Not Determined). Location of gaging point is Map ID keyed to Figure 23.

\section{Area 2 - Skellock Draw Discharge}

Discharge $\left(\mathrm{m}^{3} \mathrm{~s}^{-1}\right)$

\begin{tabular}{|c|c|c|c|c|c|c|c|c|}
\hline Location & Map ID & $\begin{array}{c}\text { 1-Apr- } \\
00 \\
\end{array}$ & $\begin{array}{c}30- \\
\text { Apr-00 } \\
\end{array}$ & $\begin{array}{c}\text { 3-Jun- } \\
00 \\
\end{array}$ & $\begin{array}{c}\text { 16-Jun- } \\
00 \\
\end{array}$ & $\begin{array}{c}\text { 21-Jun- } \\
00 \\
\end{array}$ & $\begin{array}{c}\text { 12-Jul- } \\
00 \\
\end{array}$ & $\begin{array}{c}\text { 19-Jul- } \\
00 \\
\end{array}$ \\
\hline Meadow Creek & 3 & 0.012 & 0.02 & 0.00 & 0.00 & 0.00 & 0.00 & 0.00 \\
\hline Location & Map ID & $\begin{array}{c}\text { 14-Aug- } \\
00\end{array}$ & $\begin{array}{c}9-\text { Sep- } \\
00\end{array}$ & $\begin{array}{c}21-\text { Oct- } \\
00\end{array}$ & $\begin{array}{c}\text { 18-Nov- } \\
00\end{array}$ & $\begin{array}{c}\text { 20-Jan- } \\
01\end{array}$ & $\begin{array}{c}\text { 17-Mar- } \\
01\end{array}$ & $\begin{array}{c}27- \\
\text { Apr-01 }\end{array}$ \\
\hline Meadow Creek & 3 & 0.00 & 0.00 & 0.00 & 0.00 & N.D. & 0.00 & 0.00 \\
\hline
\end{tabular}

Area 3 - Sugarpine Mountain Discharge

Discharge $\left(\mathrm{m}^{3} \mathrm{~s}^{-1}\right)$

\begin{tabular}{|c|c|c|c|c|c|c|c|c|}
\hline Location & Map ID & $\begin{array}{c}\text { 1-Apr- } \\
00\end{array}$ & $\begin{array}{c}30- \\
\text { Apr-00 } \\
\end{array}$ & $\begin{array}{c}\text { 3-Jun- } \\
00 \\
\end{array}$ & $\begin{array}{c}\text { 16-Jun- } \\
00 \\
\end{array}$ & $\begin{array}{c}\text { 21-Jun- } \\
00 \\
\end{array}$ & $\begin{array}{c}\text { 12-Jul- } \\
00 \\
\end{array}$ & $\begin{array}{c}\text { 19-Jul- } \\
00 \\
\end{array}$ \\
\hline Jack Creek & 4 & N.D. & 0.56 & 0.00 & 0.00 & 0.00 & 0.00 & 0.00 \\
\hline Mosquito Creek & 5 & N.D. & N.D. & N.D. & 0.004 & 0.00 & 0.00 & 0.00 \\
\hline Three Creek & 6 & N.D. & N.D. & N.D. & 0.01 & 0.01 & 0.008 & 0.008 \\
\hline Location & Map ID & $\begin{array}{c}\text { 14-Aug- } \\
00\end{array}$ & $\begin{array}{c}9-\text { Sep- } \\
00 \\
\end{array}$ & $\begin{array}{c}21-\text { Oct- } \\
00\end{array}$ & $\begin{array}{c}\text { 18-Nov- } \\
00 \\
\end{array}$ & $\begin{array}{c}\text { 20-Jan- } \\
01\end{array}$ & $\begin{array}{c}\text { 17-Mar- } \\
01 \\
\end{array}$ & $\begin{array}{c}27- \\
\text { Apr-01 } \\
\end{array}$ \\
\hline Jack Creek & 3 & 0.00 & 0.00 & 0.00 & 0.00 & N.D. & 0.00 & 0.00 \\
\hline Mosquito Creek & 4 & 0.00 & 0.00 & 0.00 & 0.00 & N.D. & 0.00 & N.D. \\
\hline Three Creek & 5 & 0.005 & 0.003 & 0.005 & 0.001 & N.D. & N.D. & 0.003 \\
\hline
\end{tabular}

The Williamson River flows in irrigation channels in Area 2 for roughly $14 \mathrm{~km}$ before entering the Klamath Marsh in Area 4. In Klamath Marsh no discernable 
channel exists, but flow moves generally in a southerly direction. Discharge of water moving through the Klamath Marsh was gaged at two bridges at the north end of the marsh (Military Crossing) and two bridges in the middle of the marsh (Silver Lake Highway).

In addition to the Williamson River, water enters Klamath Marsh directly from streams or indirectly from streams that apparently sink into pyroclastic-fall and-flow deposits before entering the marsh. From the west, flow from Scott, Sand, Big Springs, and Cow (not gaged) Creeks (Table 22) either flow directly into the marsh or sink into pumice deposits recharging the local water table which presumably discharges groundwater to the marsh. These streams flow across privately owned land before they discharge into the marsh, so field observations could not be made to discern how water is discharged. Topographic maps indicate that only Big Springs Creek discharges directly into Klamath Marsh, with the other streams becoming ephemeral or disappearing west of the marsh. From the east and southeast, Skellock Creek (not gaged) drains surface and shallow groundwater from Skellock Draw in Area 2 into the marsh and Yoss Creek (Table 24) drains surface and groundwater in Yoss Creek Meadow in Area 5 into Klamath Marsh. 
Table 23 - Discharge $\left(\mathrm{m}^{3} \mathrm{~s}^{-1}\right)$ measurements in Area 4 - Antelope Desert during 20002001 (N.D. = Discharge Not Determined). Location of gaging point is Map ID keyed to Figure 23.

\section{Area 4 - Antelope Desert Discharge}

Discharge $\left(\mathrm{m}^{3} \mathrm{~s}^{-1}\right)$

\begin{tabular}{lcccccccc}
\hline & Map & 1-Apr- & \multicolumn{3}{c}{30 -Apr- } & 3-Jun- & \multicolumn{3}{c}{$21-$} \\
Location & ID & 00 & 00 & 00 & $16-J u n-00$ & Jun-00 & 12-Jul-00 & $19-$ Jul-00 \\
\hline Military Crossing - East Bridge & 7 & 1.62 & 2.61 & 1.75 & 1.29 & 1.08 & 1.10 & 0.86 \\
Military Crossing - East Culvert & 7 & 0.33 & 0.43 & 0.25 & 0.12 & 0.15 & 0.05 & 0.00 \\
& & & & 0.000 & & & & \\
Military Crossing - West Bridge & 8 & 0.64 & 0.85 & 89 & -0.24 & -0.21 & -0.29 & -0.26 \\
Military Crossing - West Culvert & 8 & N.D. & 0.02 & 0.00 & 0.00 & 0.00 & 0.00 & 0.00 \\
Silver Lake Hwy - East Bridge & 9 & 4.95 & 4.08 & 1.99 & 0.75 & 0.16 & 0.09 & 0.09 \\
Silver Lake Hwy - West Bridge & 10 & 1.85 & 1.70 & 0.19 & 0.77 & 0.45 & 0.23 & 0.15 \\
Silver Lake Hwy - Culvert & 10 & 0.00 & 0.00 & 0.00 & 0.00 & 0.13 & 0.08 & 0.07 \\
Big Springs Creek & 11 & N.D. & N.D. & N.D. & N.D. & N.D. & N.D. & N.D. \\
Scott Creek & 12 & 0.00 & 0.00 & 0.28 & 0.41 & 0.41 & 0.35 & 0.33 \\
Sand Creek & 13 & 0.22 & 0.27 & 0.35 & 0.47 & 0.45 & 0.41 & 0.36 \\
\hline Location & Map & $14-$ Aug- & $9-S e p-$ & $21-O c t-$ & $18-N o v-$ & $20-$ & $17-M a r-$ & $27-A p r-$ \\
\hline \hline Military Crossing - East Bridge & 7 & 0.76 & 0.82 & 0.59 & 0.49 & 0.00 & 1.53 & 0.93 \\
Military Crossing - East Culvert & 7 & 0.00 & 0.00 & 0.00 & 0.00 & 0.00 & 0.25 & 0.12 \\
Military Crossing - West Bridge & 8 & -0.33 & -0.33 & 0.0063 & 0.00 & 0.00 & 0.54 & 0.11 \\
Military Crossing - West Culvert & 8 & 0.00 & 0.00 & 0.00 & 0.00 & 0.00 & 0.00 & 0.00 \\
Silver Lake Hwy - East Bridge & 9 & 0.00 & 0.06 & 0.01 & 0.00 & N.D. & 4.81 & 1.99 \\
Silver Lake Hwy - West Bridge & 10 & 0.01 & 0.05 & 0.0048 & 0.00 & N.D. & 2.75 & 1.26 \\
Silver Lake Hwy - Culvert & 10 & 0.004 & 0.003 & 0.0001 & 0.00 & N.D. & 0.00 & 0.00 \\
Big Springs Creek & 11 & N.D. & N.D. & N.D. & 1.57 & N.D. & N.D. & N.D. \\
Scott Creek & 12 & 0.282 & 0.267 & 0.13 & 0.00 & 0.00 & 0.00 & 0.03 \\
Sand Creek & 13 & 0.298 & 0.243 & 0.07 & 0.00 & 0.00 & 0.00 & 0.65 \\
\hline
\end{tabular}

After traveling through the marsh for approximately $16 \mathrm{~km}$, channelized flow resumes in the Williamson River. For approximately $10 \mathrm{~km}$ the Williamson River meanders in a southwesterly direction, being joined by Hog Creek (no surface channel, Table 24), crossing a bedrock high near Kirk at the southern extent of Klamath Marsh. From this point, the Williamson River enters a $100 \mathrm{~m}$ deep canyon in Area 5, where it 
flows for roughly $3 \mathrm{~km}$. USGS gaging station number 11493500 (Kirk, Table 24) at the upper end of the canyon and a gaging point maintained by this study downstream from the lower end of the canyon (Bridge 9730, Table 24) were used to monitor discharge. South of the Williamson River Canyon, the Williamson River converges with Spring Creek (Table 24). The confluence of the Williamson River and Spring Creek was the most southern monitoring point in this study. Beyond this point, the Williamson River converges with the Sprague River and eventually discharges into Upper Klamath Lake.

Table 24 - Discharge $\left(\mathrm{m}^{3} \mathrm{~s}^{-1}\right)$ measurements in Area 5 - Lower Williamson River during 2000-2001 (N.D. = Discharge Not Determined). Location of gaging point is Map ID keyed to Figure 23.

Area 5 - Lower Williamson River Discharge

$\underline{\text { Discharge }\left(\mathrm{m}^{3} \mathrm{~s}^{-1}\right)}$

\begin{tabular}{|c|c|c|c|c|c|c|c|c|}
\hline Location & $\begin{array}{c}\text { Map } \\
\text { ID } \\
\end{array}$ & $\begin{array}{c}\text { 1-Apr- } \\
00 \\
\end{array}$ & $\begin{array}{c}\text { 30-Apr- } \\
00 \\
\end{array}$ & $\begin{array}{c}\text { 3-Jun- } \\
00 \\
\end{array}$ & $\begin{array}{c}\text { 16-Jun- } \\
00 \\
\end{array}$ & $\begin{array}{c}\text { 21-Jun- } \\
00 \\
\end{array}$ & $\begin{array}{c}\text { 12-Jul- } \\
00 \\
\end{array}$ & $\begin{array}{c}\text { 19-Jul- } \\
00 \\
\end{array}$ \\
\hline Yoss Creek & 14 & 0.005 & 0.025 & 0.014 & 0.012 & 0.003 & 0.0025 & 0.002 \\
\hline Hog Creek & 15 & 0.35 & 0.28 & 0.04 & 0.02 & 0.008 & .0 .002 & 0.00 \\
\hline USGS gaging station at Kirk & 16 & 16.54 & 12.21 & 7.25 & 5.55 & 4.19 & 1.13 & 0.82 \\
\hline Lower Williamson at Bridge 9730 & 17 & 19.88 & 15.78 & 12.46 & 8.38 & 6.1 & 2.36 & 1.9 \\
\hline Spring Creek & 18 & N.D. & N.D. & N.D. & N.D. & N.D. & N.D. & N.D. \\
\hline Location & $\begin{array}{c}\text { Map } \\
\text { ID } \\
\end{array}$ & $\begin{array}{c}\text { 14-Aug- } \\
00 \\
\end{array}$ & $\begin{array}{c}\text { 9-Sep- } \\
00 \\
\end{array}$ & $\begin{array}{c}\text { 21-Oct- } \\
00 \\
\end{array}$ & $\begin{array}{c}18-N o v- \\
00 \\
\end{array}$ & $\begin{array}{c}20-J a n- \\
01 \\
\end{array}$ & $\begin{array}{c}17- \\
\text { Mar-01 } \\
\end{array}$ & $\begin{array}{c}\text { 27-Apr- } \\
01 \\
\end{array}$ \\
\hline Yoss Creek & 14 & 0.001 & 0.00 & 0.00068 & 0.00 & N.D. & 0.00 & 0.00 \\
\hline Hog Creek & 15 & 0.00 & 0.00 & 0.00 & 0.00 & 0.00 & 0.08 & 0.02 \\
\hline USGS gaging station at Kirk & 16 & 0.27 & 0.02 & 1.81 & 3.31 & 3.96 & 10.00 & NA \\
\hline Lower Williamson at Bridge 9730 & 17 & 1.07 & 1.02 & 3.24 & 5.58 & 4.94 & 11.36 & 7.87 \\
\hline Spring Creek & 18 & N.D. & N.D. & N.D. & N.D. & N.D. & 5.82 & 5.32 \\
\hline
\end{tabular}

Discharge was measured at six locations along the coarse of the Williamson River during 2000 - 2001, as well as other locations on nine streams that flow into Klamath Marsh or the Williamson River. Additionally, distance from the bridge top down to the water surface was measured at the footbridge in Area 1, East and West bridges of 
Military Crossing, East and West bridges of Silver Lake Highway, and at Forest Service Bridge 9730 below the Williamson River Canyon.

Peak discharge of streams in the Williamson River basin during the spring of 2000 occurred in April on the eastern side of the basin and occurred in mid-June on the western side. Discharge of the Williamson River at footbridge peaked near the end of April (30-April-00, $\left.3.68 \mathrm{~m}^{3} \mathrm{~s}^{-1}\right)$ and based on field observations, appears to coincide with peak snowmelt from Yamsay Mountain. Discharge was only observed at Jack Creek on April 30, $2000\left(0.56 \mathrm{~m}^{3} \mathrm{~s}^{-1}\right)$. This discharge based on field observations of snow patches appears to be almost exclusively contributed by snowmelt from surrounding highlands and Sugarpine Mountain. Peak flows for 2000 occured during April at Military Crossing (30-April-00, $3.91 \mathrm{~m}^{3} \mathrm{~s}^{-1}$ ), Silver Lake Highway (1-April-00, $\left.6.80 \mathrm{~m}^{3} \mathrm{~s}^{-1}\right)$, and the Williamson River at Bridge 9730 (1-April-00, $19.88 \mathrm{~m}^{3} \mathrm{~s}^{-1}$ ). Peak spring discharge for Scott Creek (21-June-00, $0.41 \mathrm{~m}^{3} \mathrm{~s}^{-1}$ ) and Sand Creek (16-June-00, $0.47 \mathrm{~m}^{3} \mathrm{~s}^{-1}$ ) occurs during mid-June. These two streams are located on the western side of the basin and originate in the Cascades. This delay in peak discharge relative to other streams in the basin may be attributed to the higher elevation of the source of the streams, leading to a later peak snowmelt than snow on the lower volcanic centers and highlands to the east.

Man-made diversions on Sand Creek transfer flow over to Scott Creek upstream from where discharge is gaged on these streams, discussion about the validity of flow measurements on these streams is warranted here. A portion of flow from Sand Creek is diverted into a small channel approximately $2 \mathrm{~km}$ downstream from where it passes under Sun Mountain Road (Figure 13). This channel diverts flow north for 
approximately $3 \mathrm{~km}$ to a confluence with Scott Creek. Once this diverted flow joins Scott Creek, flow continues in a easterly direction toward Klamath Marsh in Scott Creek. The distribution of flow between Sand and Scott Creek caused by this diversion produces flow in each individual stream after the diversion that is unnatural, but in a combined sense, the flow is still the same. Therefore making interpretations on flow in these streams in regard to timing of peak discharge and base-flow is valid.Surface water discharge in early September is assumed to be contributed exclusively by groundwater or base-flow conditions. This assumption is validated by observation of little if any snow cover on surrounding topography and minimal runoff generated by precipitation (Figure 3), along with minimal discharge for the study period (Tables 21, 22, 23, 24). Discharge measurements on the upper Williamson River at the footbridge gaging point indicate a base-flow of approximately $1.7 \mathrm{~m}^{3} \mathrm{~s}^{-1}\left(60 \mathrm{ft}^{3} \mathrm{~s}^{-1}\right)$ in 2000. Surface discharge in the Skellock Upland and Sugarpine Mountain areas during September, 2000 was nearly zero. Three Creek is the only surface water source within these areas that maintained flow in September, $2000\left(0.003 \mathrm{~m}^{3} \mathrm{~s}^{-1} ; 0.1 \mathrm{ft}^{3} \mathrm{~s}^{-1}\right)$. In the Antelope Desert (Area 4) area surface discharge is maintained through the fall. Discharge in Sand and Scott Creeks during September, 2000 was $0.2 \mathrm{~m}^{3} \mathrm{~s}^{-1}\left(8.6 \mathrm{ft}^{3} \mathrm{~s}^{-1}\right)$ and $0.3 \mathrm{~m}^{3} \mathrm{~s}^{-1}\left(9.4 \mathrm{ft}^{3} \mathrm{~s}^{-1}\right)$, respectively. In the Williamson River Canyon area, Hog Creek, and Yoss Creek failed to maintain flow in September, 2000. Flow of the Williamson River at Kirk approached zero (0.001 $\left.\mathrm{m}^{3} \sec ^{-1}\right)$, although flow on the Williamson River at the southern end of the canyon is maintained throughout the year. Flow of the Williamson River at Kirk went to zero during 14 of the 27 years (52\%) between $1973-2000$ (USGS Gaging Station \# 
11493500). Figure 24 shows the discharge from April, 2000 to April, 2001 on the Williamson River at Kirk, located at the northern end of the canyon and at Forest Service Bridge 9730, located at the southern end of the canyon. No additional surface water enters the Williamson River through the canyon, and it is postulated by Conaway (2000) that this additional flow must be supplied by groundwater. The difference in discharge between the north and south ends of the canyon is approximately $1.0 \mathrm{~m}^{3} \mathrm{~s}^{-1}(30$ $\left.\mathrm{ft}^{3} \mathrm{~s}^{-1}\right)$ during base-flow conditions, which is assumed to be the additional discharge added by groundwater in the canyon, similar to estimations by Conaway (2000) during $1999\left(0.87 \mathrm{~m}^{3} \mathrm{~s}^{-1}\right)$. It should be noted that during periods of high flow, velocity measurement was difficult at the Forest Service Bridge gaging point and may have introduced error into the calculation of discharge. This may account for the deviation of discharge shown in Figure 24, between the two gaging points particularly between May and June, 2000.

The relative elevation of the water surface was monitored at gaging locations on the Williamson River at Footbridge, Military Crossing (east and west bridges), Silver Lake Highway (east and west bridges), and Williamson River at Forest Service Bridge 9730 by measurement of the water surface from the top of the bridges (Table 25, Figure 25). 


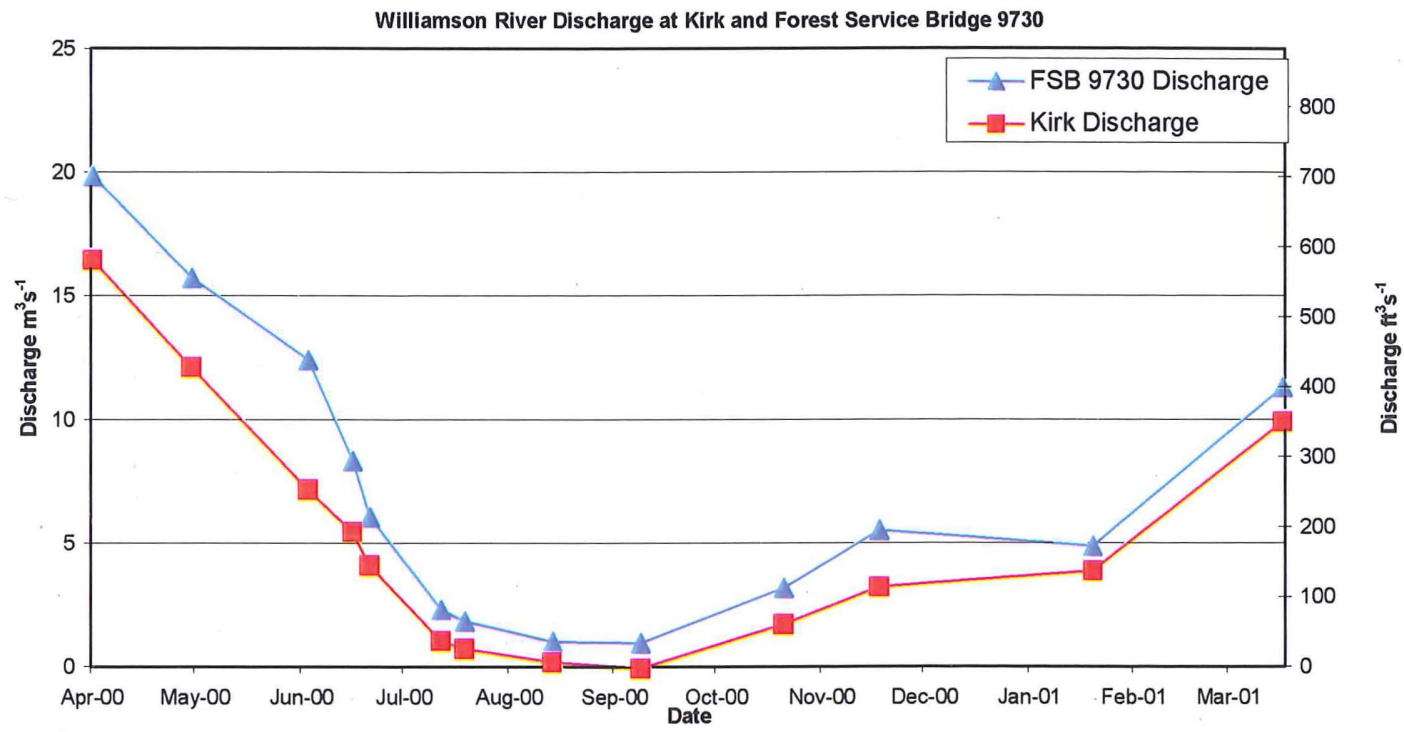

Figure 24 - Discharge on the Williamson River at Forest Service Bridge 9730 and USGS gaging station at Kirk. Discharge measured on the same day (USGS, 2000).

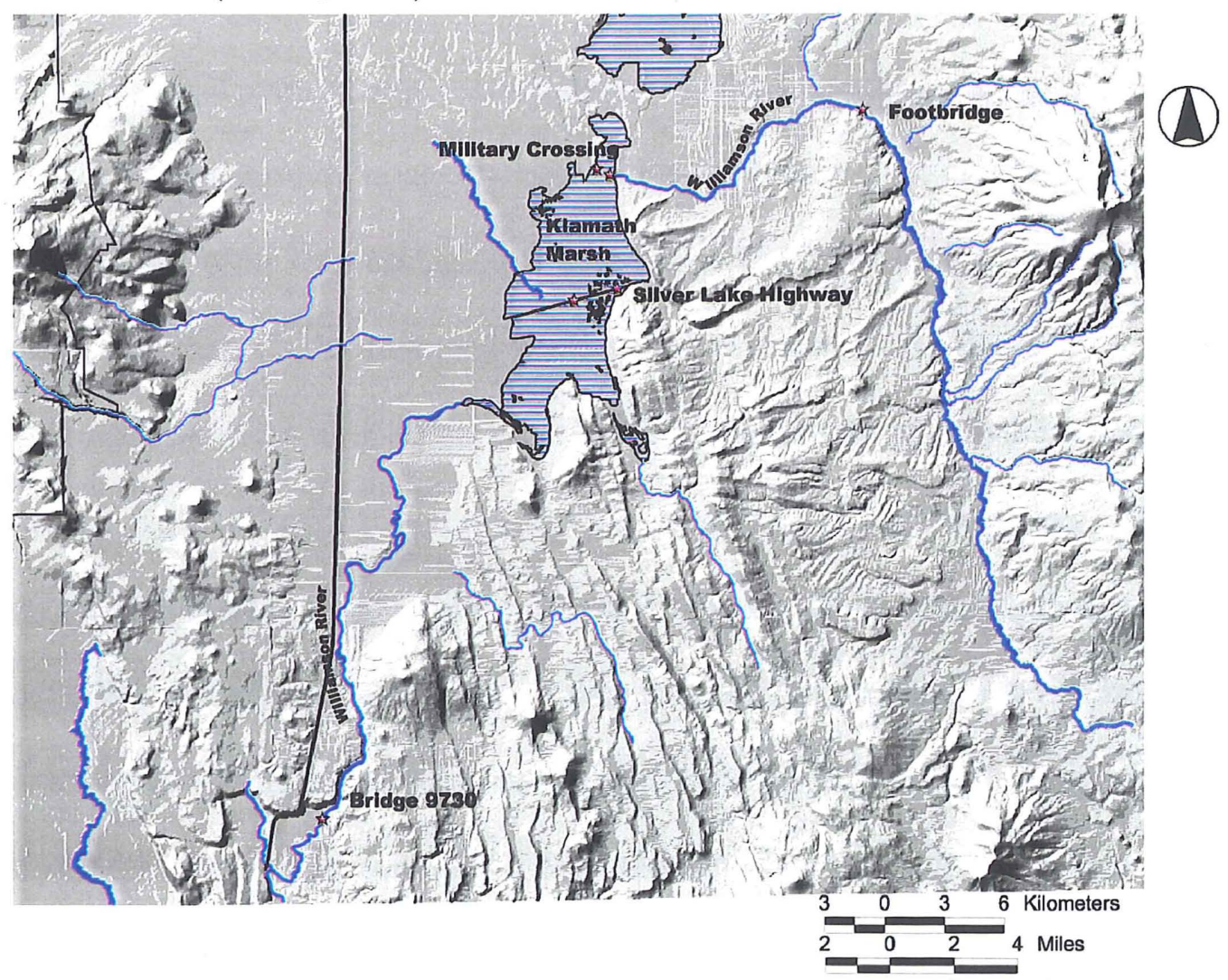

Figure 25 - Location of relative water surface elevation monitoring points. 
Table 25 - Water level measured from bridge tops at several locations on the Williamson River and Klamath Marsh. Map ID location is keyed to Figure 23. (N.D. = water level not determined).

\begin{tabular}{|c|c|c|c|c|c|c|c|}
\hline Location & $\begin{array}{l}\text { Map } \\
\text { ID }\end{array}$ & $\begin{array}{c}\text { 3-Jun- } \\
00 \\
\end{array}$ & $\begin{array}{c}\text { 16-Jun- } \\
00 \\
\end{array}$ & $\begin{array}{c}\text { 21-Jun- } \\
00 \\
\end{array}$ & $\begin{array}{c}\text { 12-Jul- } \\
00 \\
\end{array}$ & $\begin{array}{c}\text { 19-Jul- } \\
00\end{array}$ & $\begin{array}{c}\text { 14-Aug- } \\
00 \\
\end{array}$ \\
\hline Williamson River @ Footbridge & 2 & N.D. & N.D. & 1.22 & 1.23 & 1.19 & 1.20 \\
\hline Military Crossing - East Bridge & 7 & 1.10 & 1.14 & 1.14 & 1.16 & 1.20 & 1.20 \\
\hline Military Crossing - West Bridge & 8 & 1.33 & 1.33 & 1.33 & 1.34 & 1.34 & 1.39 \\
\hline Silver Lake Highway - East Bridge & 9 & 2.68 & 2.71 & 2.74 & 2.77 & 2.79 & 2.82 \\
\hline Silver Lake Highway - West Bridge & 10 & N.D. & 2.35 & 2.35 & 2.38 & 2.39 & 2.42 \\
\hline Williamson River @ FS Bridge 9730 & 17 & 2.38 & 2.59 & 2.59 & 2.89 & 2.91 & 2.99 \\
\hline Location & $\begin{array}{l}\text { Map } \\
\text { ID } \\
\end{array}$ & $\begin{array}{c}\text { 9-Sep- } \\
00 \\
\end{array}$ & $\begin{array}{c}21-O c t- \\
00 \\
\end{array}$ & $\begin{array}{c}\text { 18-Nov- } \\
00 \\
\end{array}$ & $\begin{array}{c}\text { 20-Jan- } \\
01 \\
\end{array}$ & $\begin{array}{c}17- \\
\text { Mar-01 } \\
\end{array}$ & $\begin{array}{c}\text { 27-Apr- } \\
01 \\
\end{array}$ \\
\hline Williamson River @ Footbridge & 2 & 1.19 & 1.26 & 1.24 & N.D. & N.D. & 1.37 \\
\hline Military Crossing - East Bridge & 7 & 1.20 & 1.17 & 1.17 & 1.13 & 1.14 & 1.25 \\
\hline Military Crossing - West Bridge & 8 & 1.37 & 1.34 & 1.28 & 1.26 & 1.28 & 1.36 \\
\hline Silver Lake Highway - East Bridge & 9 & 2.80 & 2.71 & 2.70 & 2.53 & 2.48 & 2.68 \\
\hline Silver Lake Highway - West Bridge & 10 & 2.42 & 2.62 & 2.32 & N.D. & 2.09 & 2.32 \\
\hline Williamson River @ FS Bridge 9730 & 17 & 2.99 & 2.79 & 2.71 & 2.67 & 2.42 & 2.44 \\
\hline
\end{tabular}

From field observations, surface flow from the Williamson River empties into Klamath Marsh, moves through the east bridge at Military Crossing and flow generally moves west. At the west bridge, flow from the east bridge combines with flow from a small marshy area to the north and together moves in a southerly direction. It should be noted that flow at the west bridge reversed direction starting sometime between June 3 and June 16, 2000 and flow to the north continued until at least September 9, 2000. This reversal is interpreted as a drop in head in the marshy area north of the west bridge, most likely as a result of evapotranspiration, causing the gradient to switch from northsouth to south-north. At Silver Lake Highway east and west bridges, water moving through the marsh is not confined to any channel and moves under the bridges, continuing to flow in a southerly direction. Water level changes in the marsh appear to be related to the rate of evapotranspiration. Figure 26 shows water levels at the four 
gaging points in Klamath Marsh from June 16, 2000 through April 27, 2001. Water levels at both Silver Lake Highway bridges dropped from June 16, 2000 through September 9, 2000, coinciding with the highest evapotranspiration rates (Figure 26). From September 9 to October 21, water levels rose $91 \mathrm{~mm}$ and $107 \mathrm{~mm}$ at the east and west bridges, respectively. This represents the largest rise in water level over the study period at these locations. Over this same period, evapotranspiration dropped from 3.1 to $1.9 \mathrm{~mm}^{-1}$ day $^{-1}$. Only $1 \mathrm{~mm}$ of precipitation fell in Skellock Draw over this period and discharge of the Williamson River entering the marsh at Military Crossing east bridge decreased from 0.82 to $0.59 \mathrm{~m}^{3} \mathrm{sec}^{-1}$, suggesting that this increase in water level in the marsh is related to the reduction in evapotranspiration. This effect may be muted

\section{Water Level fluctuation in Klamath Marsh}

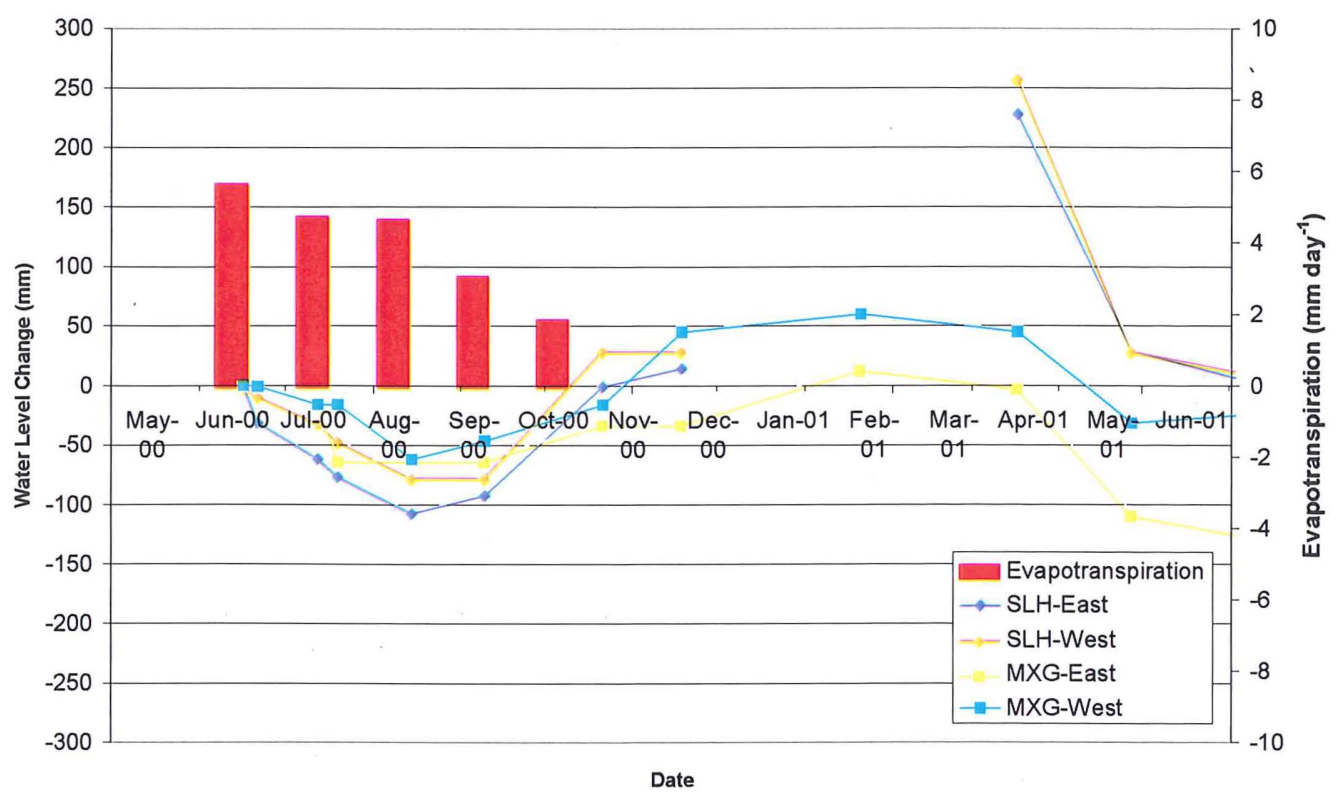

Figure 26 - Water Levels and Evapotranspiration in Klamath Marsh. Water levels are shown as a deviation from the original measurement on 3-June-00. 
at Military Crossing by the flow of the Williamson River entering the marsh, in part controlling the water level of the marsh, particularly at the east bridge.

\section{Relative In and Out Flow in Klamath Marsh}

Examination of the volume of water moving into and out of Klamath Marsh provides insight into the relative contribution of surface and groundwater sources. The purpose of this analysis is to estimate groundwater discharge to the marsh. This is done by evaluating volumetric contribution of streams that enter the marsh and comparing that volume to the volume of water that exits the marsh. The difference between the volume of water that flows out of the marsh and the volume of water added to the marsh from surface water is assumed to be groundwater.

Mathematically, this evaluation is achieved by multiplying discharge $\left(\mathrm{m}^{3} \mathrm{sec}^{-1}\right)$ at a gaging point by time (sec) between measuring periods, then summing over the entire study period (April 30, 2000 - April 27, 2001), yielding a volumetric $\left(\mathrm{m}^{3}\right)$ estimation of water moving past that particular point over the study period. The USGS gaging point on the Williamson River at Kirk is used as the outflow point of surface water from the marsh (Table 26). Inflows are from the Williamson River at the east bridge at Military Crossing, Sand and Scott Creeks combined, Yoss and Hog Creeks combined, and an unknown quantity of groundwater discharge (Table 26). Topographic maps indicate that Sand and Scott Creeks do not flow directly into Klamath Marsh. How their flow is transmitted to the marsh could not be determined due to land access. It is assumed that some flow may discharge into the marsh, but that most water sinks into pyroclastic-flow deposits near the marsh to recharge the unconfined aquifer that discharges to the marsh. 
When water volume at each inflow gaging location is summed and compared with outflow at Kirk, the difference is assumed to be discharge from groundwater west and northwest of the marsh.

Table 26 - Volume of water flow into and out of Klamath Marsh from April 30, 2000 to April 27, 2001. Negative value for evapotranspiration indicates that the volume of water was removed from Klamath Marsh.

Contribution to Klamath Marsh

\begin{tabular}{ccc}
\hline Location & $\begin{array}{c}\text { Volume of Water } \\
\left(\mathbf{m}^{\mathbf{3}}\right)\end{array}$ & $\begin{array}{c}\text { Percentage of } \\
\text { Kirk Discharge }\end{array}$ \\
\hline \hline East Military Crossing & $32,000,000$ & $10 \%$ \\
Sand and Scott Creeks & $10,000,000$ & $3 \%$ \\
Yoss and Hog Creeks & $2,000,000$ & $1 \%$ \\
Groundwater (assumed) & $280,000,000$ & $86 \%$ \\
Evapotranspiration & $(-180,000,000)$ & \\
Kirk & $144,000,000$ & \\
\hline
\end{tabular}

Approximately $180,000,000 \mathrm{~m}^{3}$ of water was removed from Klamath Marsh during the summer of 2000 based on evapotranspiration rates calculated at Skellock Draw. This is calculated by using an estimate for the size of the marsh of approximately $346 \mathrm{~km}^{2}$ and evapotranspiration of $0.52 \mathrm{~m}$ estimated by this study. This volume underestimates the actual volume because evapotranspiration was only calculated from mid-June through October of 2000, not the entire growing season. Evapotranspiration takes place in the open water body and surrounding wetland of Klamath Marsh and is a withdrawal from the outflow at Kirk. Total volume leaving the marsh is estimated by combining the volume of flow at Kirk with the volume removed by evapotranspiration for a total of 324 million $\mathrm{m}^{3}$. The combined volume of inflow into the marsh is 44 million $\mathrm{m}^{3}$ (14\% of flow at Kirk), leaving an additional 280 million $\mathrm{m}^{3}$ unaccounted. This residual volume $\left(280,000,000 \mathrm{~m}^{3}\right.$ or $86 \%$ of flow at Kirk) of water is assumed to be groundwater. Percentage of flow from each source is indicated in Table 26 and is 
illustrated in Figure 27. Removal of water from the marsh by evapotranspiration is significant in volume, accounting for more volume $\left(180\right.$ million $\left.\mathrm{m}^{3}\right)$ than the amount flowing past Kirk (144 million $\mathrm{m}^{3}$ ). Groundwater also appears to contribute significant ( $86 \%$ of inflow) volume to the marsh.

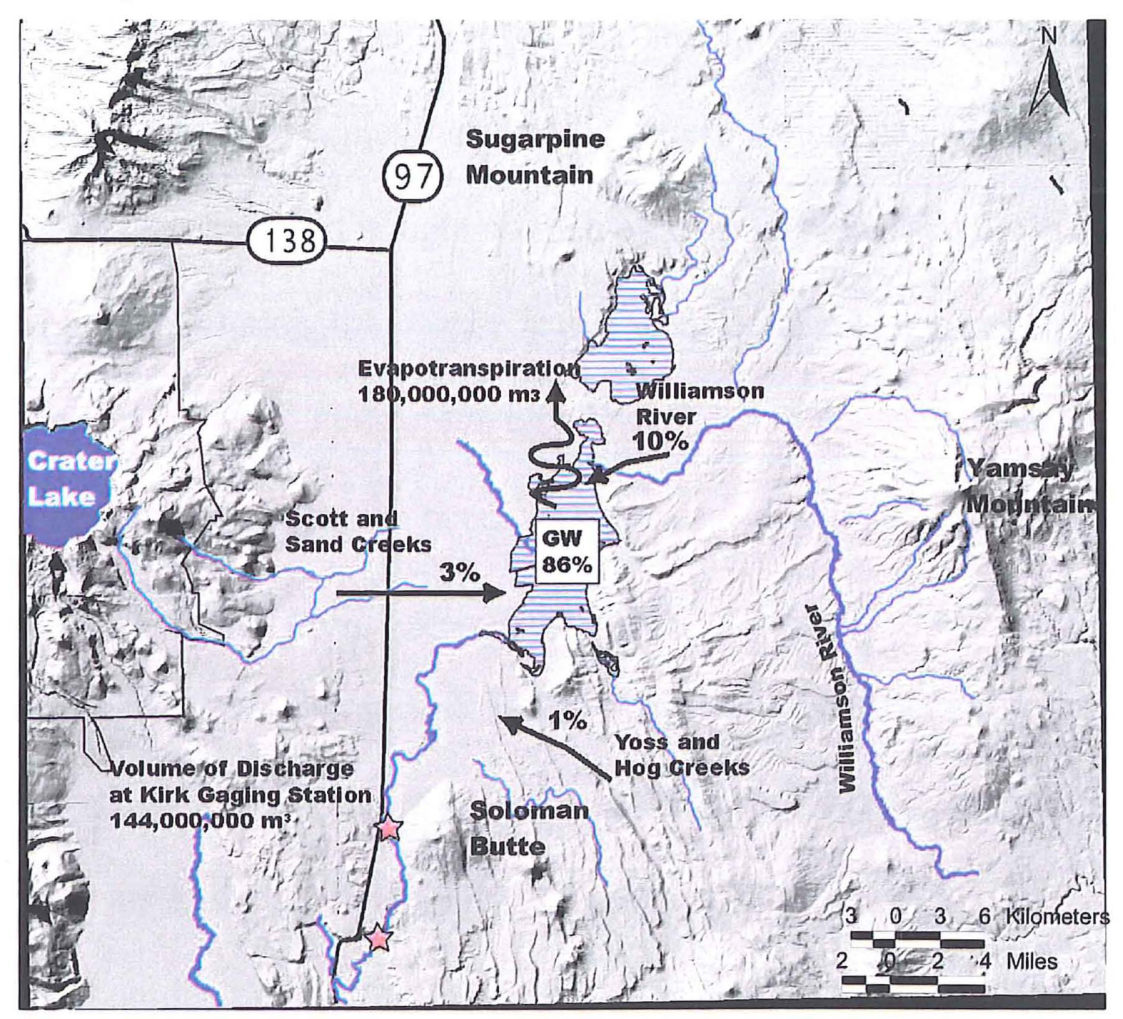

Figure 27 - Relative in and out flow at Klamath Marsh with evapotranspiration withdrawn from the discharge of the marsh.

\section{Stable Isotopes}

Deuterium and oxygen isotopes were used to trace groundwater flow paths in the Williamson River basin. Water molecules are composed of hydrogen and oxygen atoms. Hydrogen is present naturally as either common hydrogen $\left({ }^{1} \mathrm{H}\right.$; one proton), deuterium $\left({ }^{2} \mathrm{H}\right.$; one proton + one neutron), or tritium $\left({ }^{3} \mathrm{H}\right.$; one proton + two neutrons). 
Oxygen isotopes are present as either oxygen $\left({ }^{16} \mathrm{O}\right.$; eight protons + eight neutrons), heavy (very rare) oxygen $\left({ }^{17} \mathrm{O}\right.$; eight protons + nine neutrons), or heavy oxygen $\left({ }^{18} \mathrm{O}\right.$; eight protons + ten neutrons). Many molecular combinations can occur in water, but the most common are ${ }^{1} \mathrm{H}_{2}{ }^{16} \mathrm{O}$ (common), ${ }^{1} \mathrm{H}^{2} \mathrm{H}^{16} \mathrm{O}$ (rare), and ${ }^{1} \mathrm{H}_{2}{ }^{18} \mathrm{O}$ (rare) (Mazor, 1997). During evaporation, water changes from the liquid phase to the vapor phase. Isotopically light water molecules evaporate more efficiently than heavier ones. As a result, water vapor is enriched in light water molecules in regards to the evaporating liquid. During precipitation, the reverse is true, heavy water molecules condense more efficiently, leaving residual moisture in clouds depleted of deuterium and ${ }^{18} \mathrm{O}$ (Mazor, 1997). Additionally, precipitation becomes more depleted in deuterium and ${ }^{18} \mathrm{O}$ with increasing altitude (Dansgaard, 1964; Siegenthaler and Oeschger, 1980). This altitude effect imprints a signature on precipitation falling from high elevations along the crest of the Cascades on the west side of the basin to lower elevations along northern and eastern margins of the basin, potentially allowing groundwater to be traced.

Isotopic composition of water is expressed in comparison to Standard Mean Ocean Water (SMOW) (Craig, 1961a, 1961b). For this study, the isotopic composition of several water samples was determined by mass spectrometry at Geochron Laboratories in Cambridge, Massachusetts and are expressed as per mil deviations from the SMOW standard. These deviations are expressed as $\delta \mathrm{D}$ for the deuterium, and $\delta^{18} \mathrm{O}$ for ${ }^{18} \mathrm{O}$ : $\delta D=\frac{(D / H)_{\text {sample }}-(D / H)_{\text {SMOW }}}{(D / H)_{\text {SMOW }}} \times 1000$ and 


$$
\delta^{18} O=\frac{\left({ }^{18} \mathrm{O} /{ }^{16} O\right)_{\text {sample }}-\left({ }^{18} \mathrm{O} /{ }^{16} \mathrm{O}\right)_{\text {SMOW }}}{\left({ }^{18} \mathrm{O} /{ }^{16} \mathrm{O}\right)_{\text {SMOW }}} \times 1000
$$

Samples were collected during April, June, and October of 2000 and January, 2001 at Klamath Marsh, as well as springs and streams that recharge the marsh and the Williamson River on the western and eastern sides of the basin (Figure 28). The data for each site are presented in Table 27.

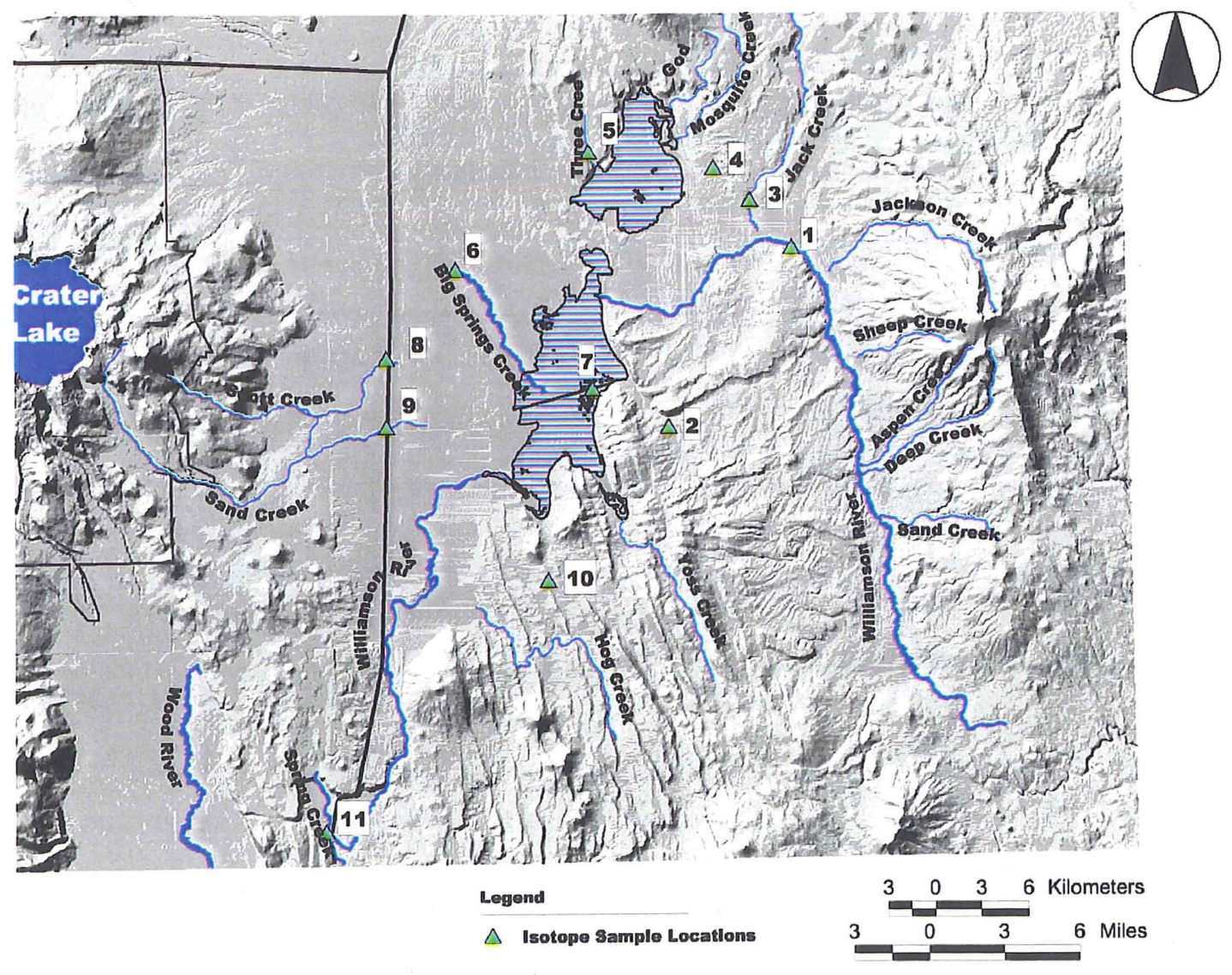

Figure 28 - Location of isotope samples near Klamath Marsh. Numbers on map are keyed to Map ID column in Table 27. 
Table 27 - $\delta \mathrm{D}$ and $\delta^{18} \mathrm{O}$ stable isotopes at selected springs and streams near Klamath Marsh. Analysis completed by Geochron Laboratories in Cambridge, Massachusetts.

\begin{tabular}{|c|c|c|c|c|}
\hline Sample Site & Map ID & Sample Date & $\delta^{18} \mathrm{O}$ & $\delta \mathrm{D}$ \\
\hline \multirow[t]{3}{*}{ Upper Williamson River@ $@$ Footbridge } & 1 & $4 / 29 / 2000$ & -15.3 & -115 \\
\hline & 1 & $4 / 29 / 2000$ & -15.3 & -116 \\
\hline & 1 & $10 / 22 / 2000$ & -15.4 & -113 \\
\hline Corral Springs & 2 & $10 / 21 / 2000$ & -15.3 & -112 \\
\hline Jack Creek & 3 & $4 / 29 / 2001$ & -14.8 & -111 \\
\hline \multirow[t]{2}{*}{ Bedpan Springs } & 4 & $6 / 3 / 2000$ & -15.8 & -118 \\
\hline & 4 & $10 / 22 / 2000$ & -15.6 & -115 \\
\hline \multirow[t]{3}{*}{ Three Creek } & 5 & $10 / 22 / 2000$ & -15.3 & -115 \\
\hline & 5 & $1 / 19 / 2001$ & -15.3 & -113 \\
\hline & 5 & $1 / 19 / 2001$ & -15.5 & -113 \\
\hline \multirow[t]{2}{*}{ Big Springs } & 6 & $6 / 16 / 2000$ & -14.4 & -108 \\
\hline & 6 & $6 / 16 / 2000$ & -14.4 & -108 \\
\hline \multirow[t]{5}{*}{ Klamath Marsh @ East Bridge Silver Lake Hwy } & 7 & $6 / 4 / 2000$ & -13.4 & -105 \\
\hline & 7 & $6 / 4 / 2000$ & -13.4 & -106 \\
\hline & 7 & $10 / 21 / 2000$ & -11.8 & -92 \\
\hline & 7 & $1 / 19 / 2001$ & -15.4 & -115 \\
\hline & 7 & $1 / 19 / 2001$ & -15.4 & -115 \\
\hline \multirow[t]{2}{*}{ Scott Creek@ Hwy 97} & 8 & $6 / 4 / 2000$ & -14.8 & -108 \\
\hline & 8 & $10 / 21 / 2000$ & -14.4 & -102 \\
\hline \multirow[t]{4}{*}{ Sand Creek@ Hwy 97} & 9 & $6 / 4 / 2000$ & -14.8 & -109 \\
\hline & 9 & $6 / 4 / 2000$ & -14.9 & -109 \\
\hline & 9 & $10 / 21 / 2000$ & -14.5 & -103 \\
\hline & 9 & $10 / 21 / 2000$ & -14.5 & -103 \\
\hline Dice Crane Spring. & 10 & $10 / 21 / 2000$ & -15.1 & -113 \\
\hline \multirow[t]{2}{*}{ Spring Creek@ Hwy 97} & 11 & $4 / 29 / 2000$ & -14.5 & -110 \\
\hline & 11 & $10 / 21 / 2000$ & -14.3 & -106 \\
\hline
\end{tabular}


Deuterium and oxygen stable isotopes suggest source waters in the basin have distinguishable signatures. Figure 29 shows isotopic composition of samples collected near Klamath Marsh split by their location relative to being east or west of the WRMC fault zone. Sources to the west of WRMC fault zone are believed to originate in

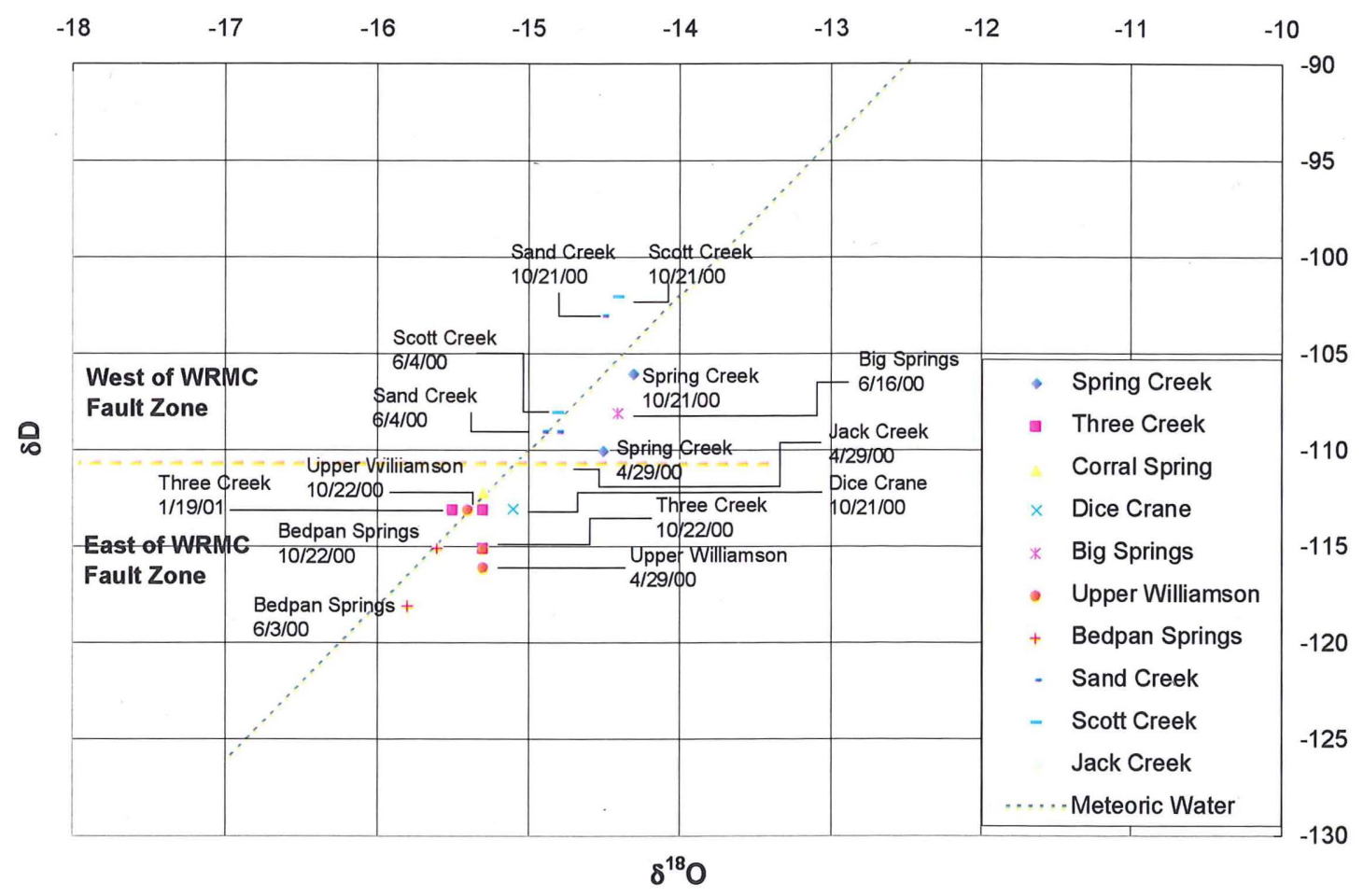

Figure 29 - Deuterium and oxygen isotopes showing apparent split between sample location relative to WRMC Fault Zone.

the Cascades and should have a heavier (more positive) isotopic signature from preferential fractionation from the relatively high elevation at which precipitation occurred. Samples collected east of WRMC fault zone are believed to originate on Sugarpine Mountain, Yamsay Mountain, and highlands around the marsh. These areas are relatively lower in elevation compared to the Cascades and lie in the rain shadow produced by the mountain range, both of which should result in fractionated 
precipitation that is relatively light (more negative) isotopically. The imprint of fractionation induced by the rain shadow effect and differing elevations where precipitation is taking place on the isotopic composition of precipitation appears to be responsible for the clustering of the deuterium and $\mathrm{O}^{18}$ isotope ratios of source waters.

Several locations were sampled during the spring and in the fall of 2000 to examine the change in isotopic composition from peak discharge to base flow conditions. Evaporation preferentially removes light isotopes causing ratios in the melting snowpack to become enriched in deuterium and $\mathrm{O}^{18}$ isotopes (more positive). Figure 30 shows the shift in deuterium and oxygen ratios at locations where multiple samples were analyzed. These shifts are within the analytical error, so any interpretation of the shift is potentially unfounded.

Isotopic ratios of water in Klamath Marsh were examined in the spring, fall, and winter to determine contribution of water to the marsh by western and eastern sources. Figure 31 shows the isotopic shift of water in Klamath Marsh sampled at the east bridge of Silver Lake Highway (SLH East). On 14-June-2000, water in the marsh displays isotopic ratios similar to sources west of WRMC fault zone, with an additional slightly evaporative component. From 14-June-2000 to 21-October-2000, water in the marsh displays an evaporative trend, becoming enriched in deuterium and $\mathrm{O}^{18}$ isotopes. From 21-October-2000 to 19-January-2001, water in the marsh becomes significantly more depleted in deuterium and $\mathrm{O}^{18}$ isotopes (more negative). 


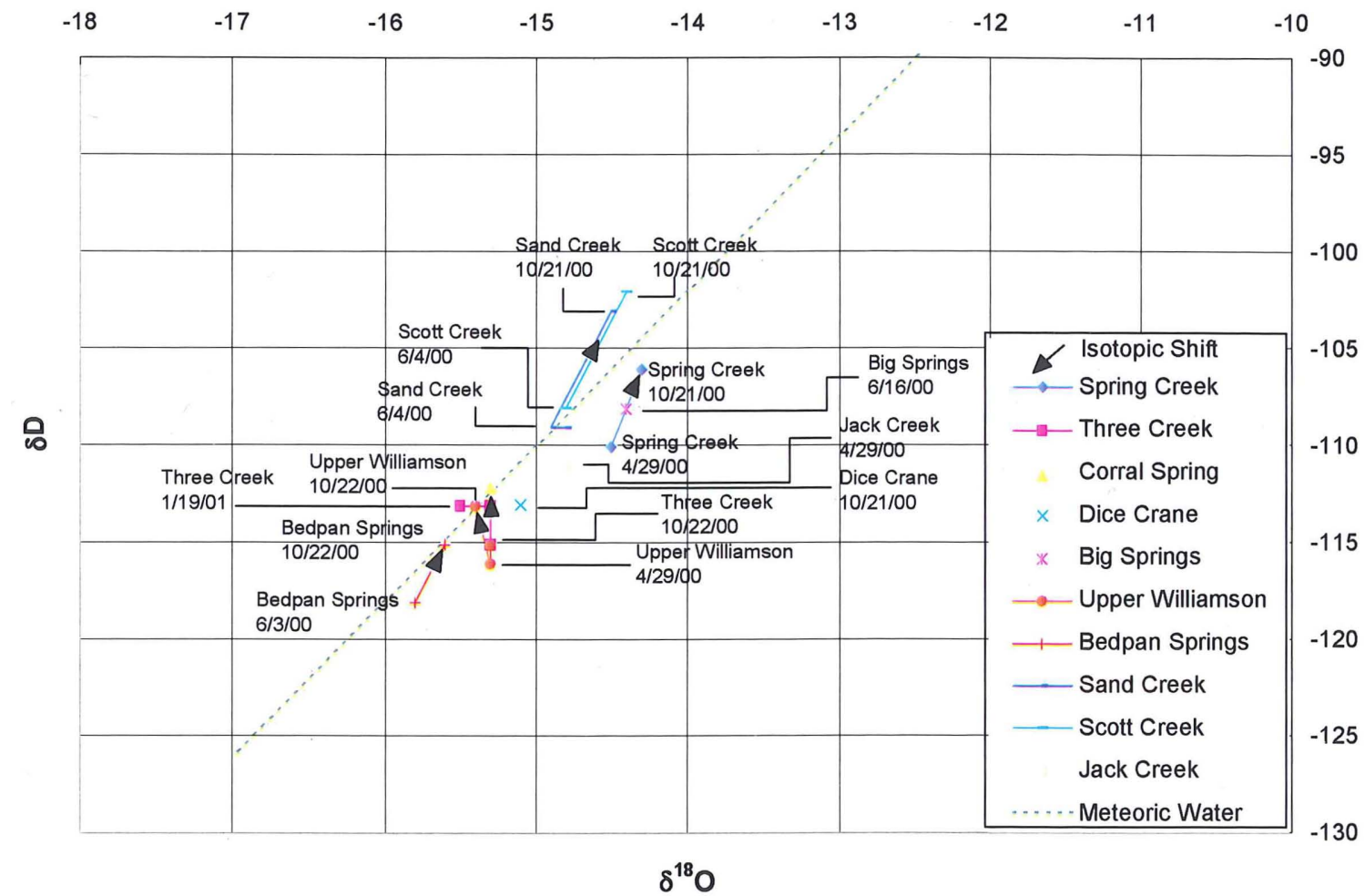

Figure 30 - Evaporation trends in deuterium and oxygen isotopic ratios. Isotopic shifts indicated by arrow.

Interpretation of this observation is unclear. By January, water in the marsh appears to become similar to isotopic ratios of sources east of WRMC fault zone. Samples were not obtained for eastern and western sources on 19-January-2001, so interpretation in regards to source water is not plausible. Additional data are needed from sources entering the marsh in winter to determine the cause of the shift in deuterium and $\mathrm{O}^{18}$ isotopic ratios. 


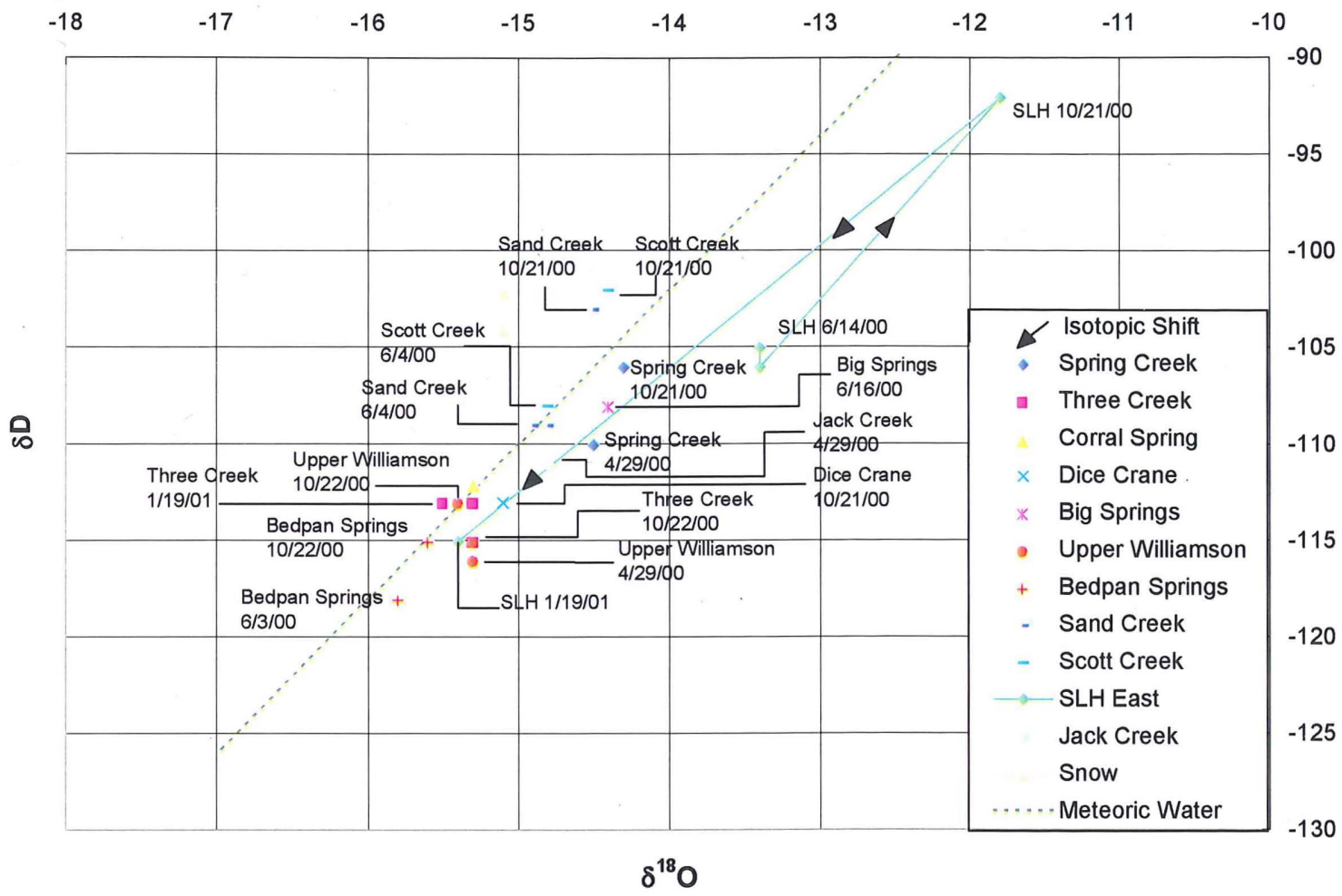

Figure 31 - Isotopic ratios around Klamath Marsh with evaporative trend in marsh water indicated by arrow. 


\section{Chapter 3 - Discussion}

Locations of ground and surface water recharge and discharge areas in the Williamson River basin are controlled by spatial variability in precipitation, patterns in evapotranspiration, infiltration characteristics of surface geologic units, and permeability of bedrock geologic units. The aim of this discussion is to integrate key hydrogeologic observations to examine ground and surface water flow paths in the Williamson River basin.

\section{Recharge Infilltration}

Precipitation and evapotranspiration control the amount of water available to recharge aquifers in a drainage basin. In the Williamson River basin, distribution of precipitation varies spatially (Figure 9); regions along the Cascade crest (mean $=107.8$

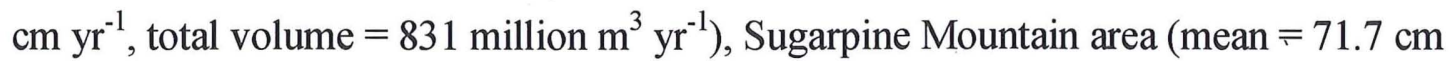
$\mathrm{yr}^{-1}$, total volume $=488.5$ million $\left.\mathrm{m}^{3} \mathrm{yr}^{-1}\right)$, and Yamsay Mountain area $($ mean $=66.5 \mathrm{~cm}$ $\mathrm{yr}^{-1}$, total volume $=362$ million $\left.\mathrm{m}^{3} \mathrm{yr}^{-1}\right)$ receiving the highest amounts of precipitation. Evapotranspiration estimates by this study, Bidlake (1997), and Bidlake and Payne (1998) indicate rates in the range of 67.4 to $91.1 \mathrm{~cm}$ per summer growing season. When evapotranspiration is removed from precipitation, the residual amount is the volume available to recharge aquifers. Recharge is the highest (Table 8) along the Cascade crest (Area 4 - Cascades), Sugarpine Mountain (Area 3), and Yamsay Mountain (Area 1).

Pyroclastic-fall and -flow deposits formed during the climactic eruption of Mount Mazama exhibit differing water infiltration characteristics. Pyroclastic-fall deposits mantle topography to the north, east and south of Klamath Marsh, while pyroclastic- 
flow deposits underlie parts of the marsh and west to the Cascade foothills. Analysis of pyroclastic-fall materials indicate grain size ranges from lapillus $(64 \mathrm{~mm}-2 \mathrm{~mm})$ to fine ash $(<0.675 \mathrm{~mm})$. The water content in the pumice is replenished by winter snow melt and spring precipitation. The holding capacity of the pyroclastic-fall deposits is a function of grain size distribution and thickness of the deposits, with the highest water weight in the lapillus sized clasts. Data from piezometers in Skellock Draw suggest that the precipitation received during the winter of 2000-2001 was not adequate to exceed the water holding capacity of the pyroclastic-fall deposits. The estimated precipitation for that winter was $24 \mathrm{~cm}$.

It is suggested, based on these observations, that the recharge over much of the basin may have been near the values estimated in this study for the winter of 1999 2000 , but that in the winter of $2000-2001$ the recharge may have been near zero.

Likewise, the infiltration rate of the pyroclastic-flow deposits based on discharge data for Sand Creek is estimated to be $10^{-6}-10^{-5} \mathrm{~m} \mathrm{~s}^{-1}$. This low infiltration rate, coupled with low annual precipitation (Figure 9) and high evapotranspiration in the areas underlain by pyroclastic-flow deposits suggests that the recharge in areas underlain by these deposits is also low.

The highest recharge occurs in Area 4, Area 3, and Area 1 as a result of higher precipitation over these regions. Precipitation that falls on pyroclastic-fall material infiltrates readily, with the lapillus size pumice holding infiltrating water, limiting recharge to the local water table. Water trapped in the pumice supplies water to stands of Ponderosa, Lodgepole, Sugar Pine, as well as other shrubs and grasses surrounding 
Klamath Marsh, removing water from the basin by transpiration. Precipitation falling on pyroclastic-flow deposits also infiltrates into the subsurface, but at a lower rate than in the pyroclastic-fall deposits. Pyroclastic-flow material likely acts as a semi-confining unit for aquifers under Area 4. The majority of recharge from the Cascade crest likely is transmitted to the aquifers underlying Area 4.

\section{Bedrock Geology and Hydrogeologic Observations}

Variability in the hydrodynamic properties of bedrock units surrounding Klamath Marsh controls groundwater flow paths in the Williamson River basin. Indurated and partially welded pyroclastic tuffs and dense lava flows underlie the eastern and southern side of the Williamson River basin. Yamsay Mountain in Area 1 is underlain by basaltic andesite lava flows, several dacite domes, and pyroclastic flows (Hering, 1981). These materials appear to transmit limited amounts of groundwater to springs at the head of the Williamson River and several other springs along its course in Area 1. Water wells in this area indicate moderate yields in unconsolidated and consolidated sediments. Base-flow conditions indicate approximately $1.7 \mathrm{~m}^{3} \mathrm{sec}^{-1}$ of the flow of the Williamson River is from groundwater in Area 1. Overall, Area 1 is considered moderate in its volumetric contribution of surface and groundwater to the system.

The tuff of Skellock Draw and tuff of Meadow Creek, two highly lithified, partially welded tuffs underlie Area 2 (Cummings et al., in review). Based on estimates using piezometers in Skellock Draw, the infiltration rate of the tuff of Skellock Draw is between $8.9 \times 10^{-8}$ and $3.7 \times 10^{-8} \mathrm{~m} \mathrm{sec}^{-1}$. The tuff of Meadow Creek is a highly indurated, alkali-rich pyroclastic flow with characteristic trachyandesite pumice blocks 
that onlaps the tuff of Skellock Draw in the eastern half of Area 2 (Cummings et al., in review). Transmisive characteristics of this unit are unknown, but observation in outcrop indicates low permeability. Overlying these tuffs are basaltic andesite flows that form Wildhorse Ridge (Cummings et al., in review). Water wells in the northern section of Area 2 tap lava flows under the tuff of Skellock Draw for low yields.

Although geologic mapping has not been completed north of Klamath Marsh in Area 3, information about the geology gathered during this study indicate thin basalt flows are the prominent geologic unit. Based on rates of water decline in piezometers in the Jack Creek area, these vesicular basalt flows appear to be relatively permeable. Spring snowmelt in 2000, likely from Sugarpine Mountain, produced surface water discharge $\left(0.56 \mathrm{~m}^{3} \mathrm{sec}^{-1}\right)$ in Jack Creek that decreased to zero by early June. After surface flow ceases, flow continues in the subsurface through pyroclastic-fall deposits draining toward the Williamson River where it flows through the northern section of Area 2. Surface water flow (Table 22) was observed only on the first visit to Mosquito Creek, was not observed in God Creek, and was observed throughout the study period at Three Creek. These streams and likely groundwater from this area flow into the northern detached segment of Klamath Marsh, likely supplying the water that fills this section of the marsh.

The down-dropped block of the WRMC fault zone underlying Area 4 has accumulated at least $195 \mathrm{~m}$ of clastic sedimentary rocks and lava flows. Water well driller's logs indicate artesian flow and yields up to 4000 gpm from wells drilled in this area. Big Springs appears to be a discharge point for groundwater in the aquifer, 
discharging $1.57 \mathrm{~m}^{3} \mathrm{sec}^{-1}$ in November of 2000. Newcomb and Hart (1958) and Leonard and Harris (1974) also indicate that Big Springs appears to be an overflow point of this aquifer. Potentiometeric surface maps generated by both studies indicate that groundwater in the aquifer tapped by water wells in this region flows from the northern section of Area 4 in a southeasterly direction toward Klamath Marsh. It is likely that Klamath Marsh is in direct connection with this aquifer and water level in the marsh is controlled primarily by water levels in this aquifer. Volumeteric analysis of water flowing through Klamath Marsh indicates that approximately $86 \%$ of inflowing water is groundwater, most likely from this aquifer underlying Area 4. This area contributes the most significant amount of water to the system and is of foremost importance in terms of recharge to the Williamson River basin.

The geology of the area south of Klamath Marsh in Area 5 is characterized by faulted basaltic lava flows, hydrovolcanics, and sedimentary rocks. Water wells in this area indicate low to high yields ranging from $20 \mathrm{gpm}$ to $1950 \mathrm{gpm}$. This indicates a vast range of permeability, likely as a result of fracturing of brittle volcanic flows during faulting, increasing permeability and complex stratagraphic relations among lava flows and sedimentary rock. Observation of surface water discharge in Area 5 indicates Yoss Creek and Hog Creek do not contribute significant amounts of flow to the marsh or Williamson River. Groundwater flow equating to approximately $1 \mathrm{~m}^{3} \mathrm{sec}^{-1}$ is added to discharge through the Williamson River canyon. The source of this groundwater is unknown, but additional isotope analysis of this water after flow has ceased at Kirk may indicate potential sources within the basin. Below the Williamson River canyon, Spring 
Creek joins the Williamson River and contributed $34 \%$ of the combined flow below their confluence in March of 2001, and $40 \%$ of the combined flow in April of 2001, based on discharge shown in Table 24. The source for water flowing from the spring that feeds Spring Creek is unknown and based on its large contribution to water leaving the Williamson River basin requires additional study.

\section{Hydrogeologic Summary}

Water flow in Klamath Marsh is characterized by two distinct hydrogeologic regimes, spatial variability in recharge, groundwater dominated inflow, and evapotranspiration-dominated outflow. Over the course of observation during $2000-$ 2001, several key interpretations have been made regarding the flow of water into and out of Klamath Marsh.

Infiltration into bedrock units east of WRMC fault zone in Areas 1, 2, and 3 appears to be inhibited by several ash flow tuffs and lava flows, while west of the fault zone sedimentary rock and thin fractured basalt flows readily transmit water. The water level in Klamath Marsh is primarily controlled by a transmissive aquifer located west and northwest of the marsh that receives recharge from the Cascades.

Evapotranspiration in the marsh appears to remove more water volumetrically than water flowing out of the marsh in the Williamson River over the study period. Isotopic composition of water from locations around the marsh display groupings that apparently are related to regions of similar precipitation, potentially allowing surface and groundwater flow paths in the basin to be traced. 
Conceptual flow models synthesize information gathered during this study and provide visualization of water flow in the basin. Ground and surface water flow paths display differing magnitudes during peak and base flow conditions. Because of this difference, two conceptual models are proposed, one for flow in the spring and another for flow in the fall.

During Peak flow conditions in the spring (Figure 32), surface water flow moves

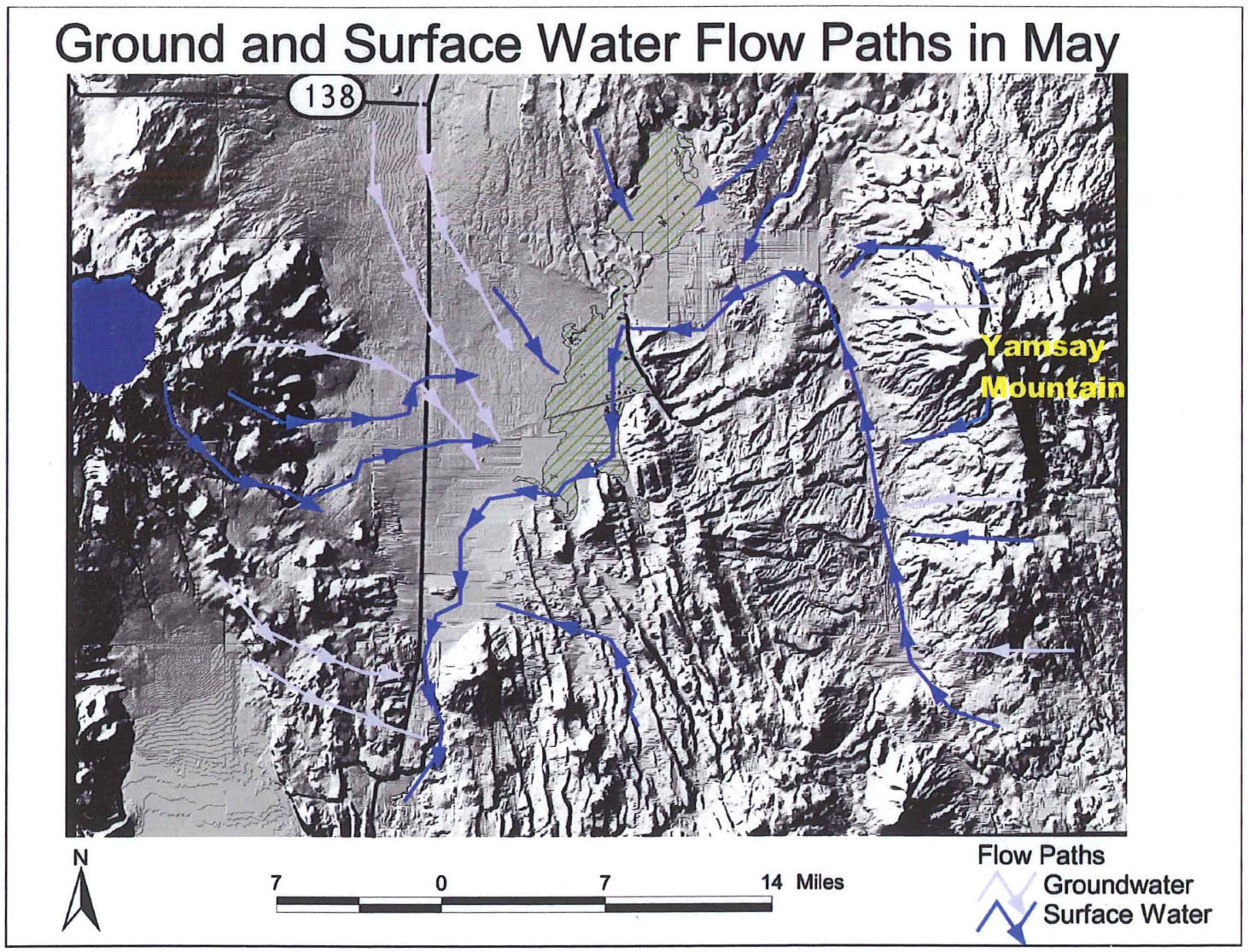

Figure 32 - Conceptual model of ground and surface water flow paths near Klamath Marsh in May.

to the north from the source of the Williamson River, receiving additional flow from streams draining Yamsay Mountain and potentially gaining flow from groundwater 
discharge. At Klamath Marsh, the Williamson River combines with groundwater moving in from the west and northwest. At the southern end of Klamath Marsh, surface water rechannelizes, flows over the bedrock ridge at Kirk and enters the Williamson River Canyon. In the canyon, additional flow is added by groundwater.

During the Fall (Figure 33), surface water again flows north from the headwaters of the Williamson River, gaining limited flow from surface water and groundwater originating from Yamsay Mountain. Surface water flow at the north end of Klamath Marsh splits, with some flowing into a small marshy area north of Military Crossing and

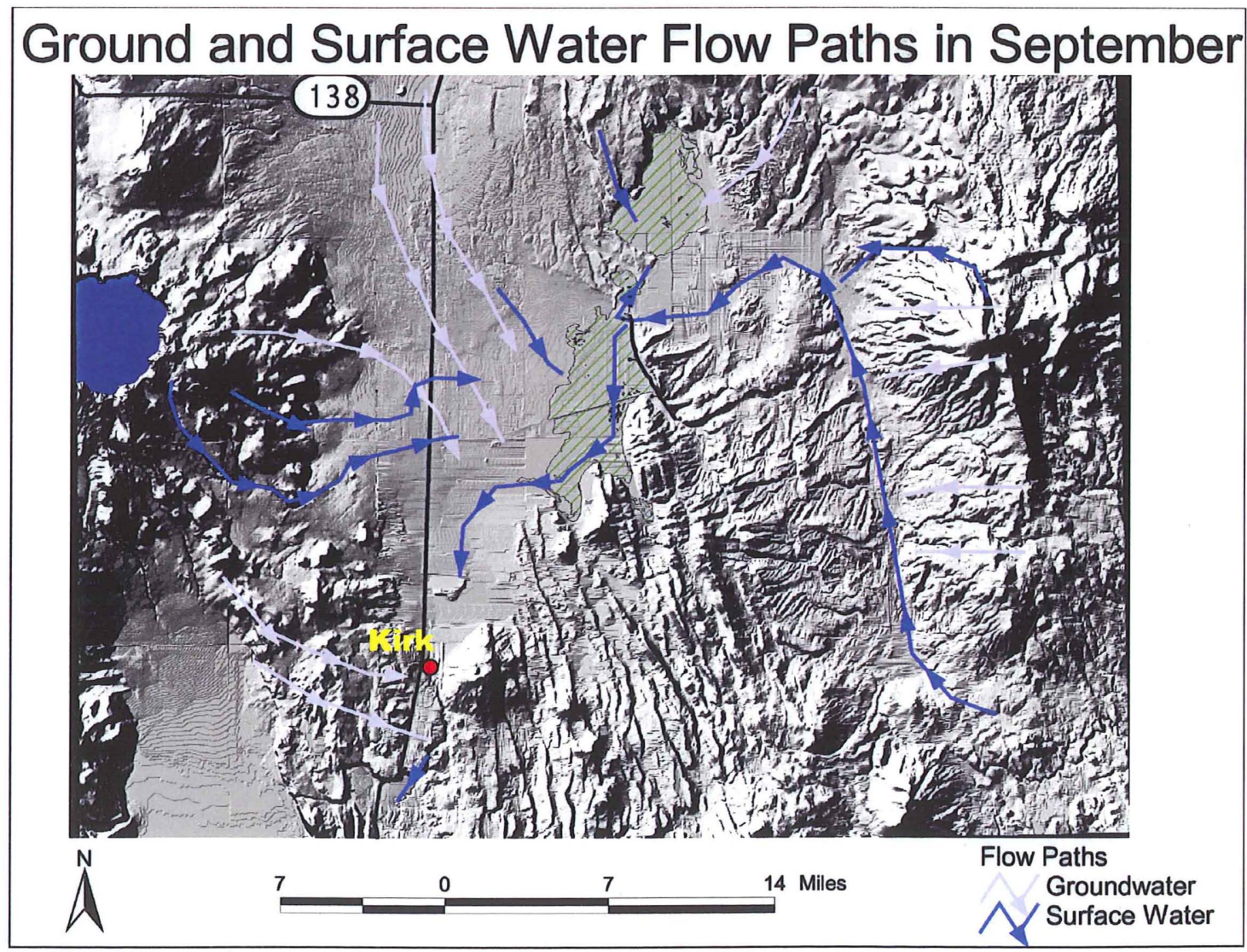

Figure 33 - Conceptual model of ground and surface water flow paths near Klamath Marsh in September. 
the remainder flowing south. At the southern end of the marsh, water level, lowered by evaporation and reduced inflow, drops below ground-surface elevation at Kirk, causing flow of the Williamson River to stop. Below Kirk in the Williamson River Canyon, groundwater discharge returns flow to the Williamson River. 


\section{Chapter 4 - Conclusions}

Precipitation distribution analysis, evapotranspiration calculation and application over the basin, consolidation of geologic information, and hydrologic observations during 2000-2001 in the Williamson River basin near Klamath Marsh provide a detailed examination of the hydrogeologic character of this region. The rain shadow effect from the Cascades creates preferential recharge zones in regions of elevated topography, with lowlands receiving barely more precipitation than evapotranspiration. Additionally, the Williamson River basin is dissected by the WRMC fault zone which divides geology east of the zone from vastly different geology in a hydrogeologic sense to the west.

Precipitation patterns and evapotranspiration indicate that the Cascade crest along the western border of the basin in Area 4 - Cascades supplies the most voluminous recharge to the basin. Sugarpine Mountain (Area 3) and Yamsay Mountain (Area 1) receive elevated precipitation, but because of their relatively small areas are not significant volumetrically. During years of below normal precipitation, evapotranspiration in regions referred to in this study as Area 2, Area 4 - Antelope Desert, and Area 5 likely exceeds precipitation.

Geologic mapping and assimilation of previously acquired geologic information indicates the eastern side of the WRMC fault zone is underlain by highly indurated pyroclastic tuffs and low permeability lava flows that inhibit groundwater flow to Klamath Marsh. West of the WRMC fault zone, thick deposits of medium to coarse grained sedimentary rocks and brecciated and vesiculated lava flows are host to an aquifer that supplies large volumes of water to local water wells and potentially controls 
the water level of Klamath Marsh. Faulting south of the marsh (Area 5) has increased local permeability, but most likely does not increase groundwater discharge to Klamath Marsh from this region.

The Williamson River above Klamath Marsh receives surface water during snowmelt and perennial groundwater supplied by the Yamsay Mountain volcanic complex. Klamath Marsh is dominated by groundwater recharge presumably from precipitation falling on the Cascade crest, with additional flow from the Upper Williamson River and other small streams entering the marsh. The Williamson River below Klamath Marsh during periods of high flow is dominated by flow from the marsh and during periods of low flow is dominated by groundwater discharge in the Williamson River canyon. 


\section{References}

Adams, R. M., and Cho, S.H., 1998, Agriculture and endangered species: An analysis of trade-offs in the Klamath Basin, Oregon: Water Resources Research, v. 34, no. 10 , pp. $2741-2749$

Bacon, C. R., 1983, Eruptive history of Mount Mazama and Crater Lake caldera, Cascade range, U.S.A.: Journal of Volcanology and Geothrmal Research, v. 18, p. 57-115.

Bacon, C. R., Lanphere, M. A., Champion, D. E., 1999, Late Quaternary slip rate and seismic hazards of the West Klamath Lake fault zone near Crater Lake, Oregon Cascades: Geology, v. 27, no. 1, p. 43-46.

Bidlake, W.R., 1997, Evapotranspiration from selected wetlands at Klamath Forest and Lower Klamath National Wildlife Refuges, Oregon and California: United States Geological Survey Administrative Report, 19 pp.

Bidlake, W.R., and Payne, K.L., 1998, Evapotranspiration from selected wetlands at Klamath Forest and Upper Klamath National Wildlife Refuges, Oregon: United States Geological Survey Administrative Report, 21 pp.

Conaway, J. S., 2000, Hydrology and paleohydrology in the Williamson River Basin, Klamath County, Oregon [M.S. thesis]: Portland State University, Portland, Oregon, $117 \mathrm{p}$.

Conaway, J. S., and Cummings, M. L., in press, Geologic map of the Wocus Bay quadrangle, Klamath County, Oregon: Oregon Department of Geology and Mineral Industries, GMS -, scale 1:24000.

Craig, H., 1961a, Isotopic variation in meteoric waters: Science, v. 133, p. 1702-1703.

Craig, H., 1961b, Standard for reporting concentrations of deuterium and oxygen-18 in natural waters: Science, v. 133, p. 1833-1834.

Cummings, M. L., and Melady, J. M., 2002, Hydrogeology of Klamath Marsh, Klamath County, Oregon: Report to the United States Bureau of Reclamation, contract number 00FG200085, $71 \mathrm{pp}$. 
Cummings, M. L., Bragg, H., and Meyer, C., in review, Geology of the Wildhorse Ridge quadrangle, Klamath County, Oregon: Oregon Department of Geology and Mineral Industries, GMS -, scale 1:24000.

Dansgaard, W. , 1964, Stable isotopes in precipitation: Tellus, v. 16, p. 436-469.

Dong, A., Grattan, S. R., Carroll, J.J., and Prashar, C.R.K, 1992, Estimation of net radiation over well-watered grass: Journal of Irrigation and Drainage Division, ASCE , v. 118, no. 3, pp 466-479.

Fiebelkorn, R. B., Walker, G. W., MacLeod, N. S., McKee, E. H., and Smith, J. G., 1983, Index to K-Ar age determinations for the State of Oregon: Isochron/West, no. 37 , p. 3-60.

Gardner, J. E., Carey, S., and Haraldur, S., 1998, Plinian eruptions at Glacier Peak and Newberry volcanoes, United States: Implications for volcanic hazards in the Cascade Range: Geological Society of America Bulletin, v. 110, no. 2, p. 173187.

Hering, C. W., 1981, Geology and petrology of the Yamsay Mountain complex, southcentral Oregon: A study of bimodal volcanism [Dissertation]: University of Oregon, Eugene, Oregon, 194 p.

Jensen, M.E., Burman, R.D., and Allen, R.G., 1990, Evapotranspiration and irrigation water requirements: American Society of Civil Engineers Manuals and Reports on Engineering Practice, Irrigation and Drainage Division, n. 70, p. 42

Lee, C. L., 2000, Magmatic processes operating during the middle to late Pliocene and Pleistocene along the Cascades-Basin and Range transition zone near $43^{\circ}$ North [M. S. thesis], Portland State University, Portland, Oregon, 162 p.

Lee, C. L., and Cummings, M. L., in press, Geologic map of the Soloman Butte quadrangle, Klamath County, Oregon: Oregon Department of Geology and Mineral Industries, GMS -, scale 1:24000.

Leonard, A. R., and Harris, A. B., 1974, Ground water in selected areas in the Klamath Basin, Oregon: Oregon State Engineer Groundwater Report, no. 21, 104 p. 
Mazor, E., 1997, Chemical and isotopic groundwater hydrology: The Applied Approach: New York, Marcel Dekker, Inc., 413 p.

McKee, E.H., MacLeod, N.S., and Walker, G.W., 1976, Potassium-Argon ages of late Cenozoic silicic volcanic rocks, southeast Oregon: Isochron/West, no. 15, p. 3741.

Melady, J. M., and Cummings, M. L., umpublished mapping, 2000, Geologic map of the Military Crossing quadrangle, Klamath County, Oregon: Oregon Department of Geology and Mineral Industries, GMS -, scale 1:24000.

Newcomb, R. C., and Hart, D. H., 1958, Preliminary report on the ground water resources of the Klamath River Basin, Oregon: U. S. Geological Survey unnumbered Open-File Report, p. 248.

NOAA, 2000, Weather station data site, http://lwf.ncdc.noaa.gov/oa/ncdc.html, accessed 24 January 2000. A copy is available from the author.

Oregon Climate Service, 2001, Annual precipitation spatial data for Oregon, http://www.ocs.orst.edu/prism/state products/or maps.html, accessed on 2 May 2001. A copy is available from the author.

Oregon Department of Agriculture, 2001, 2000-2001 Oregon Agriculture and Fisheries Statistics, http://oda.state.or.us/oass/bul901.pdf, accessed 27 Sept 2001. 1 p. A copy is available from the author.

Oregon Water Resources Department, 2001, GRID Web Water Well Driller's Logs, http://deschutes.wrd.state.or.us/apps/gw/well_log/, accessed 20 May 2001. A copy is available from the author.

Peterson, N. V., and McIntyre, J. R., 1970, The reconnaissance geology and mineral resources of eastern Klamath County and western Lake County, Oregon: Oregon Department of Geology and Mineral Industries Bulletin, no. 66, p. 70.

Pezzopane, S. K., and Weldon II, R. J., 1993, Tectonic role of active faulting in central Oregon: Tectonics, v. 12, p. 1140-1169.

Pruitt, W.O., and Doorenbos, J., 1977, Empirical calibration, a requisite for evapotranspiration formulae based on daily or longer mean climatic data, 
presented at the ICID conference on Evapotranspiration, Budapest, Hungary, May 26-28, 1977, International Commission on Irrigation and Drainage.

Saiki, M. K., Monda, D. P., and Bellerud, B. L., 1999, Lethal levels of selected water quality variables to larval and juvenile Lost River and Shortnose suckers: Environmental Pollution, v. 105, no. 1, p. 37.

Schmid, R., 1981, Descriptive nomenclature and classification of pyroclastic deposits and fragments: recommendations of the IUGS subcommission on the systematics of igneous rocks: Geology, v. 9, p. 41-43.

Sherrod, D. R., Pickthorn, L.B.G., 1992, Geologic map of the west half of the Klamath Falls $1^{\circ}$ by $2^{\circ}$ quadrangle, south-central Oregon: U. S. Geological Survey Miscellaneous Investigation Series Map I-2182, scale 1:250,000.

Siegenthaler, U., Oeschger, H., 1980, Correction of ${ }^{18} \mathrm{O}$ in precipitation with temperature and altitude: Nature, v. 285, p. 314-317.

Snyder, R. L., Pruitt, W. O., 1992, Evapotranspiration data management in California, Irrigation and Drainage Session Proceedings/Water Forum, Baltimore, MD, American Society of Civil Engineers, p. 128-133.

U.S. Bureau of Reclamation, 1993, Klamath project general information and history, http://www.rsgis.do.usbr.gov/html/klamathh.html, accessed 11 Nov. 2001., A copy is available from the author.

United States Fish and Wildlife Service, 2002, Klamath Basin National Wildlife Refuges. http://www.klamathnwr.org/history.html, accessed on 31 Mar 2002. 1 p. A copy is available from the author.

USGS, 2000, Stream gage data. http://waterdata.usgs.gov/nwis/OR/data. components/hist.cgi?statnum=11493500, accessed 24 January 2000. A copy is available from the author.

Winema National Forest, 1997, Watersheds and subwatersheds Arcview coverage, http://www.fs.fed.us/r6/winema/mapsdata/gis/index.shtml, accessed on 14 April 2000. A copy is available from the author. 
Zdanowicz, C. M., Zielinski, G. A., and Germani, M. S., 1999, Mount Mazama eruption: Calendrical age verified and atmospheric impact assessed: Geology, v. 27, p. 621-624. 


\section{Appendix A - Calculation of Evapotranspiration}

Snyder and Pruitt (1992) suggest the use of a modified Penman equation for the calculation of evapotranspiration with hourly meteorological observations to calculate hourly reference evaptranspiration. Equation 2 is used during daylight hours and Equation 3 is used during night hours.

$$
\begin{aligned}
& \left.E T_{0}=\sum E_{i} \quad \text { for hour } \mathrm{i}=1 \text { to } 24 \quad \text { (in } \mathrm{mm}\right) \\
& E_{i}=W_{i} \times R_{n}+\left(1-W_{i}\right) \times\left(e_{a i}-e_{d i}\right) \times F_{d i} \quad \text { for } \mathrm{R}_{\mathrm{n}}>0 \\
& E_{i}=W_{i} \times R_{n}+\left(1-W_{i}\right) \times\left(e_{a i}-e_{d i}\right) \times F_{n i} \quad \text { for } \mathrm{R}_{\mathrm{n}} \leq 0
\end{aligned}
$$

Variables that are used in equations 2 and 3 are measured or computed for the $\mathrm{i}^{\text {th }}$ hour of each day as shown in the following sections:

Measured Variables:

$$
\begin{aligned}
& \mathrm{T}_{\mathrm{i}}=\text { mean air temperature in }{ }^{\circ} \mathrm{C} \\
& \mathrm{P}_{\mathrm{b}}=\text { Barometric pressure in } \mathrm{kPa} \\
& \mathrm{e}_{\mathrm{di}}=\text { mean vapor pressure in } \mathrm{kPa} \\
& \mathrm{U}_{\mathrm{i}}=\text { mean wind speed in } \mathrm{m} \mathrm{s}^{-1} \\
& \mathrm{R}_{\mathrm{s}}=\text { mean solar radiation in } \mathrm{W} \mathrm{m}^{-2}
\end{aligned}
$$


Computed Variables:

$\mathrm{R}_{\mathrm{n}}=$ net radiation $=\mathrm{f}\left(\mathrm{R}_{\mathrm{s}}, \mathrm{T}_{\mathrm{i}}\right) \quad \mathrm{mm}$

$W_{i}=\Delta_{i} /\left(\Delta_{i}+\gamma_{i}\right)$

where,

$\begin{array}{ll}-\Delta_{i}=\left(e_{a i} / T_{K i}\right) \times\left(\left(6790.4985 / T_{K i}\right)-5.02808\right) & \\ \text { where, } & \\ & \\ & e_{a i}=0.6108 \times \exp \left[\left(17.27 \times T_{i}\right) /\left(T_{i}+237.3\right)\right] \quad \mathrm{kPa} \\ & \\ & \text { where, }\end{array}$

- $T_{K i}=273.16+T_{i} \quad$ Kelvin

- $\gamma_{i}=0.000646 \times\left(1+0.000946 \times T_{i}\right) \times P_{b} \quad \mathrm{kPa}{ }^{\circ} \mathrm{C}^{-1}$
$F_{d i}=0.038+0.0576 \times U_{i}$
$\mathrm{mm} \mathrm{kPa}^{-1}$
$F_{n i}=0.125+0.0439 \times U_{i}$
$\mathrm{mm} \mathrm{kPa}^{-1}$

Net radiation in $\mathrm{W} \mathrm{m}^{-2}\left(\mathrm{R}_{\mathrm{n}}\right)$ is calculated by the method described by Dong et al. (1992). $R_{n}$ is then divided by the latent heat of vaporization $(\lambda)$ for the equivalent millimeters of evaporation. 


$$
\begin{array}{ll}
\lambda=694.5\left(1-.000946 \times T_{i}\right) & \mathrm{W} \mathrm{m}^{-2} \mathrm{~mm}^{-1} \\
R_{n}=0.89\left[(1-\alpha) R_{s}+\varepsilon_{a}(O)(1-c) \sigma T_{k i}^{4}+c \sigma T_{k i}^{4}-0.98 \sigma T_{l i}^{4}\right] &
\end{array}
$$

where,

$$
\text { - } \alpha=0.00158 \Theta+0.386 \exp (-0.0188 \Theta) \quad \text { when } \frac{R s}{I}<0.375
$$

$$
\text { - } \alpha=0.26 \quad \text { when } \frac{R s}{I}>0.375
$$

- $c=\left(1.33-1.33 \frac{R s}{R a}\right)^{0.294} \quad$ if $\mathrm{c}>1$ then $\mathrm{c}=1$, if $\mathrm{c}<0$ then $\mathrm{c}=1$

where,

$$
\text { - } \quad R a=\left(0.79-\frac{3.75}{\Theta}\right) I \quad \text { where } \Theta=\text { solar altitude }
$$

where,

- $\quad I=I_{o} \cos Z \quad$ where $\mathrm{I}_{\mathrm{o}}=1370 \mathrm{~W} \mathrm{~m}^{-2} \& \mathrm{Z}=$ solar zenith angle where,

- $\cos (Z)=\sin (\Theta)=(\sin \phi)(\sin \delta)+(\cos \phi)(\cos \delta)(\cos \mathrm{H})$

where

$$
\begin{aligned}
& \Theta=\text { solar altitude } \\
& \phi=\text { latitude of site } \\
& \delta=\text { solar declination }
\end{aligned}
$$




$$
\begin{aligned}
& \mathrm{H}=\text { hour angle } \\
& \delta=-23.45 \cos \left[\frac{360\left(t_{j}+10\right)}{365}\right] \text { where } \mathrm{t}_{\mathrm{j}}=\text { Julian date } \\
& \varepsilon_{a}(O)=1.08\left[1-\exp \left(e_{d i}^{T k i / 2016}\right)\right] \quad \text { where } \mathrm{e}_{\mathrm{di}} \text { is expressed in millibars and } \mathrm{T}_{\mathrm{ki}} \text { in Kelvin }
\end{aligned}
$$


Appendix B - Selected Water Well Logs 
File Original and
First Copy with the
STATE WNGINEER,
SALEM, OREGON

(1) OWNER:

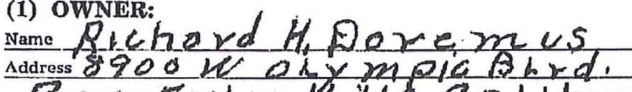
Benterhy.lat calikom (2) LOCATION OF WELL:

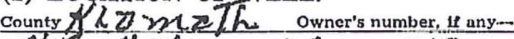

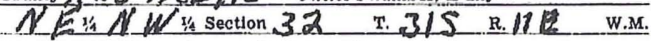
Bearing and distance from section or subdivision corner.

(3) TYPE OF WORK (check):

New Well 级 Deepening $\square \quad$ Reconditloning $\square \quad$ Abandon $\square$ If- donment, describe material and procedure in Item 11.

(4) PROPOSED USE (check):

Domestic Industrial $\square$ Municipal $\square$ Irrigation $\square$ Test well $\square$ other

(6) CASING INSTALLIED: Threaded $\square$ Welded 8

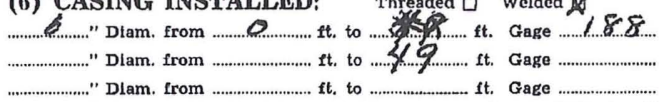
(7) PERFORATIONS: Perforated? $\square$ Yos 每 No Type of perforator used

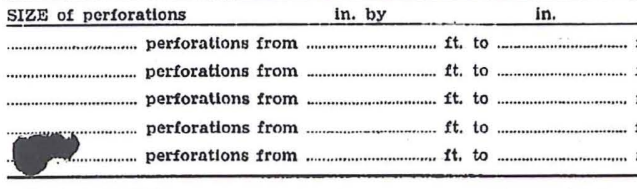

(8) SCREENS: Well screen installed $\square$ Yes

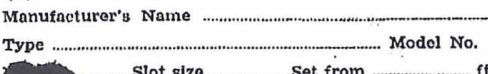

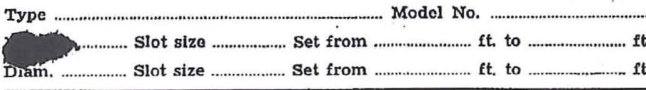
(9) CONSTRUCTION:

Was well gravel packed? $\square$ Yes 0 No Slze of gravel: Gravel placed from ............................... ft. to ........................... ft.

Was a surface seal provided? $\square$ Yes $\square$ No To what depth? Dld any strata contain unusable water? $\square$ Yes 8 No

Type of water? Depth of strata Method of sealing strata off

(10) WATER LEVELS: Static level $\$ / / 2$ it. below land surface Date $76 / 62$ Artesian pressure $\quad$ lbs. per square inch Date

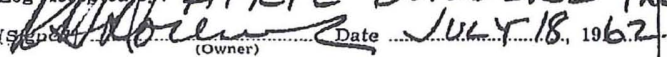
(USE ADDITTONAL SHEETS IF NECESSARY)

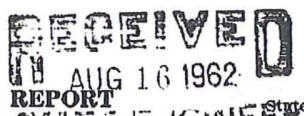

REPORT

GoN

(11) WELL TESTS: Drawdown is amount water level is

Was n pump test made? $\square$ Yes 19 No If yos, by whom?

\begin{tabular}{lccc}
\hline Yiold: & gal./min. with & ft. drawdown after & hrs. \\
\hline$"$ & $"$ & $"$ & $"$ \\
\hline$"$ & $"$ & & \\
\hline
\end{tabular}

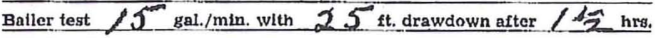
Arteslan flow g.p.m. Date

Temperature of water 98 Was a chemical analysis made? $\square$ Yes d No

(12) WELL LOG: Dlameter of well ......... . ............. inches. Depth drilled $\langle Q\rangle$ ft. Dopth of completed well $\langle Q\rangle$ Formation: Describe by color, character, size of material and structure, and stratum penetrated, with at least one entry for each change of formattor. \begin{tabular}{c|c|c}
\hline MATTRIAL & FROM & TO \\
\hline
\end{tabular}

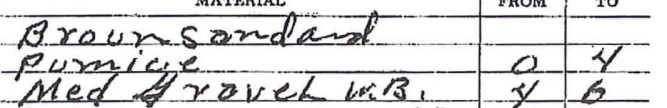
Med Groveh whi $y=\frac{6}{6 y}$

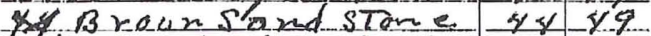
firoy cinder pockus 4973 Red Girdarkack w 13 - 73 10y

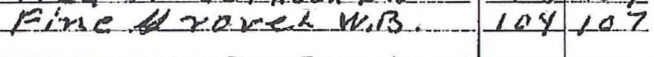

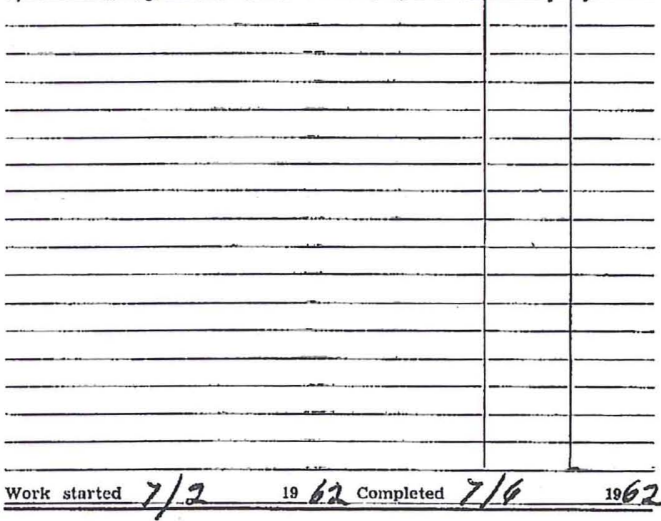

(13) PUMP:

Manufacturer's Name

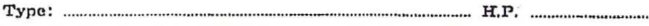

Well Drillex's Statement:

This well was drilled under my jurisdiction and this report is

true to the best of my knowledge and belief.

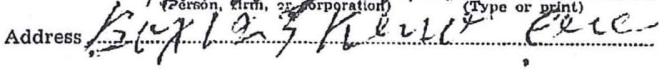

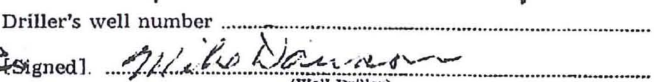

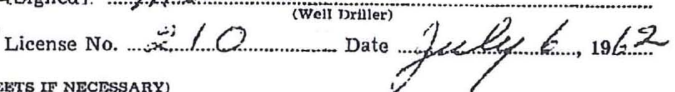




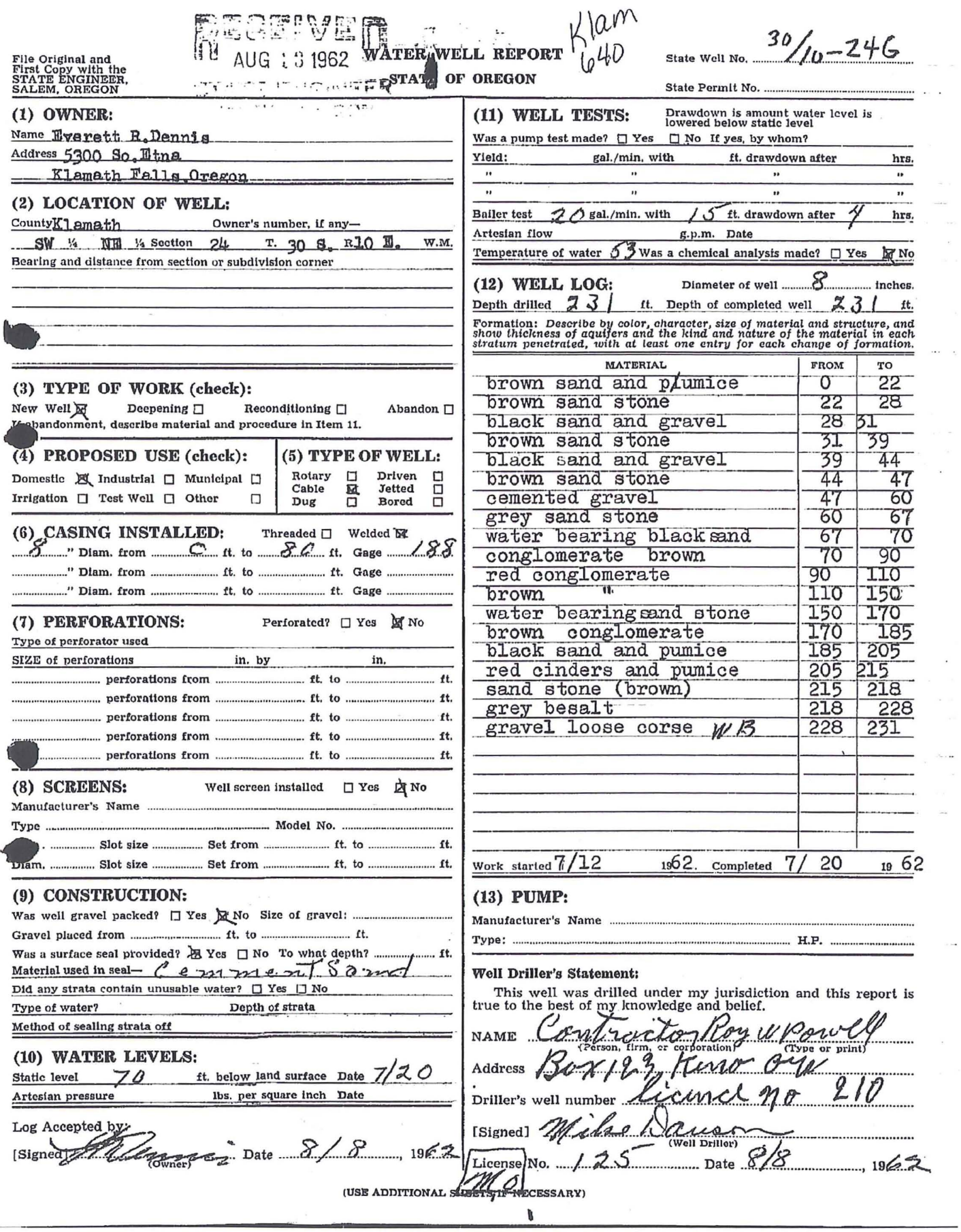




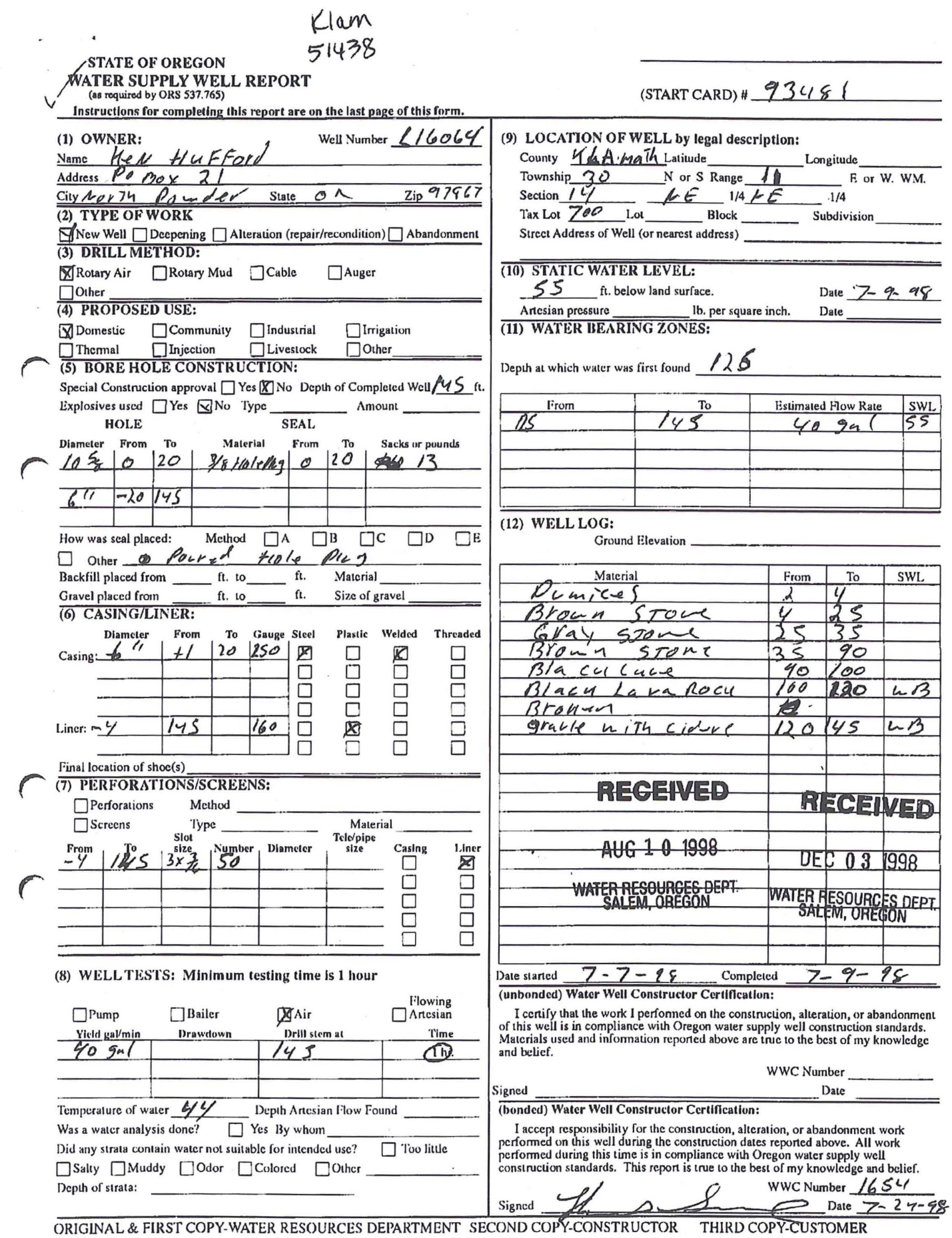

ORIGINAL \& FIRST COPY-WATER RESOURCES DEPARTMENT SECOND COPY-CONSTRUCTOR THIRD COPY-CUSTOMER 


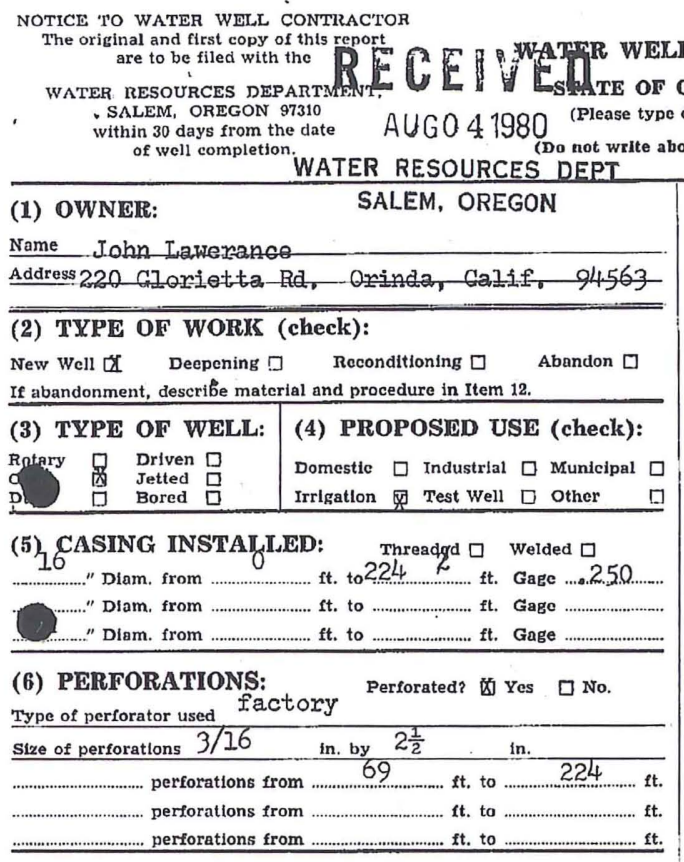

(7) SCREENS: Well screen installed? $\square$ Xes $\square$ L No

Manufacturer's Name ...........................................................................................................

Type ……................................................................. Model No. ..................................... f.

Dtam. ……….... Slot size ............... Set from ...................... ft. to …………...... rt.

(8) WELL TESTS: $\begin{aligned} & \text { Drawdown is amount water level is } \\ & \text { lowered below static level }\end{aligned}$

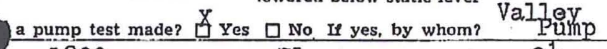
YYcld: 1800 gal. $/ \mathrm{min}$. with? 1 ft. drawdown after $2 \frac{1}{2} \mathrm{hrs}$.

\begin{tabular}{|c|c|c|c|}
\hline 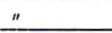 & $"$ & $"$ & $"$ \\
\hline$"$ & " & $"$ & ". \\
\hline er test. & gal./min. with & ft. drawdown after & hrs. \\
\hline Mestan flov & p. & & \\
\hline
\end{tabular}

\section{(9) CONSTRUCTION:}

Well seal-Material used c..................

Well sealed from land surface to .....18

Dlameter of well bore to bottom of seal ....20!............... in.

Diameter of well bore below seal 16 ............. in.

Number of sacks of cement used in well seal ........13.......................... sacks

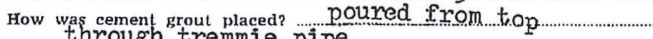

through tremmie pipe

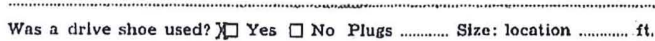
Did any strata contain unusable water? $\square$ Yes ${ }^{2}$ No

Type of water? ________epth of strata

Method of sealing strata off

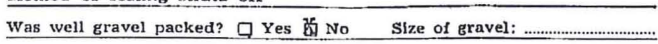

Gravel placed from ....................... ft. to ......................... ft. . . . _ _
oRECEIVED

WATER RESOURCEStatDSRTII No

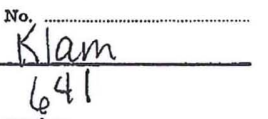

(10) LOCATION OF WELL: County Klamath Driller's well number

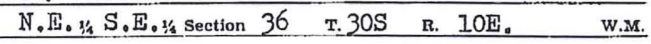

Bearing and distance from section or subdivision corner

(11) WATER LEVEL: Completed well.

Depth at which water was first found 39 ft.

Static level $39 \quad$ it. below land surface. Date $7 / 14 / 80$

Artesian pressure lbs. per square Inch. Date

(12) WELL LOG: Diameter of well below easing .........12................ Depth drilled $290 \quad$ ft. Depth of completed well $290 \quad$ ft.

Formation: Describe color, texture, grain size and structure of materials; and show thickness and nature of each stratum and aquifer penetratod positlon of statlc Water Level and indleate princlpal water-bearing strata,

\begin{tabular}{|c|c|c|c|}
\hline MATERIAI & From & To & swL \\
\hline pumic, gravel \& houlders & 0 & 9 & \\
\hline Java howlders & 9 & -17 & \\
\hline rotten lava. & 11 & 14 & \\
\hline pumica, sand \& yellow clay & 74 & 50 & 39 \\
\hline grave], sand \& pumic & 50 & 72 & \# \\
\hline lava boulders & 72 & 74 & II \\
\hline sand, gravel \& houlders & 74 & 87 & \# \\
\hline grave 1 , yellow clay \& sand & 87 & 93. & "I \\
\hline pumaic \& brown sand & 83 & 102 & "I \\
\hline brown sandstone \& boulders & 102 & 130 & $"$ \\
\hline brown lava. & 130 & 136 & "11 \\
\hline brown sandstone \& boulders & 136 & 166 & " \\
\hline broken Iaya \& yellow clay & -166 & -175 & 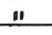 \\
\hline hard gray hasalt & 775 & 290 & $n$ \\
\hline & & & \\
\hline & & & \\
\hline & & & \\
\hline & & & \\
\hline
\end{tabular}

\begin{tabular}{lllll}
\hline Work started $6 / 10$ & 19 & 80 Completed & $7 / 22$ & 19
\end{tabular} $\begin{array}{llll}\text { Date well drilling machine moved off of well } & 7 / 28 & 18 \quad 80\end{array}$

Drilling Machine Operator's Certifioation:

This well was constructed under my direct supervision. Materials used and information reported above are true to $\mathrm{my}$

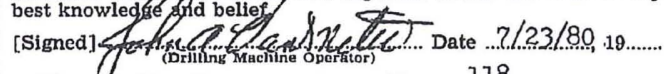
Drilling anachine Operator's License No. ........118

Water Well Contractor's Certification:

This well was drilled under my jurisdiction and this report is true to the best of my knowledge and belief.

Name John A. Van Meter

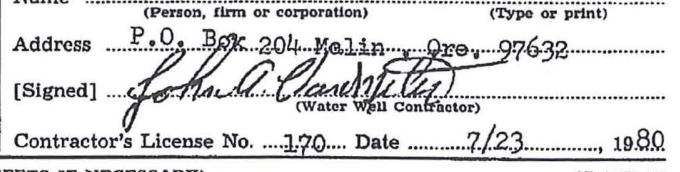


NOTYCE TO WATER WELL CONTRACTOR The original and first copy

filed with the
STATE ENGINEER, SALEM, oREGo

WATER WELL REPORT within 30 days from the date of well completion.

AUG 15 1977Do not writo above this line)

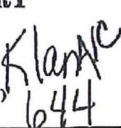

state well No. $308 / 10 E-366 b$

State Permit No.

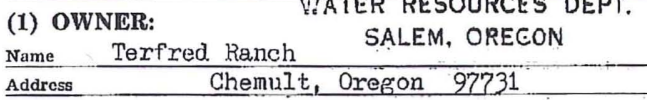

\section{(2) TYPE OF WORK (check):}

New Well ख Deepening $\square \quad$ Reconditioning $\square \quad$ Abandon $\square$ If abandonment, describe material and procedure in Item 12.

(3) TYPE OF WELL: (4) PROPOSED USE (check): Rotary
Cable $\begin{aligned} & \text { Driven } \\ & \text { Jetted }\end{aligned} \quad$ Domestic 度 Industrial $\square$ Municipal $\square$ Dug $\square$ Bored $\square \quad$ Irrigation $\square$ Test Well $\square$ Other

CASING INSTALLED:

$65 / 8$ Threaded $\square$ Wolded if

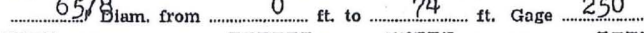

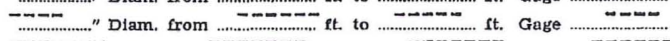
from

\begin{tabular}{l} 
(v) PERTORATIONS: \\
Type of perforntor used \\
Size of perforations \\
\hline$\ldots y$.
\end{tabular}

(7) SCREENS:

Well screen installed? $\square$ Yes $\square$ No

Type -

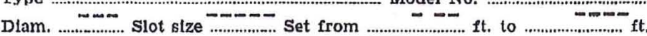

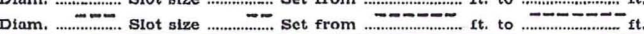

(8) WELL TESTS: $\begin{aligned} & \text { Drawdown is amount water level is } \\ & \text { lowered below static level }\end{aligned}$

Was a pump test made? $\square$ Yes 画 No If yes, by whom?

ld: - - - - gal./min. with -- tt drawdown after $-\cdots-$ hrs. Air Li fted from 100 feet 100 G.B.M. for two hours.

Baller test - - - s sal./min. with - $\mathrm{ft}^{-}$drawdown after - Frs.

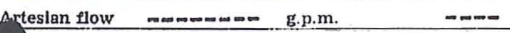

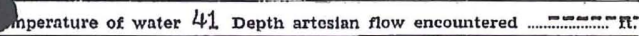

(9) CONSTRUCTION:

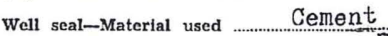

Well sealed from land surface to .......... 70

Diameter of well bore to bottom of seal ...10 .................... in.

Dlameter of well bore below seal ................... in.

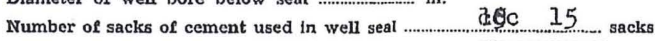

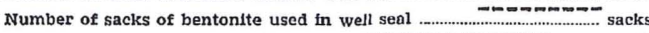

Brand nome of hentonite

Number of pounds of bentonite per 100 fallons

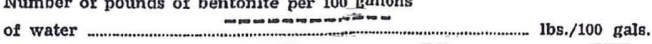

Was a drive shoe used? $\square$ Yes 首 No Plugs .......... Size: location ........... $\mathrm{ft}$.

Did any strata contain unusable water? 므 Yes $\otimes$ No

Type of water? =-

Method of sealing strata off

Was well gravel packed? $\square$ Yes 犯 No Size of gravel:

Was well gravel packed? $\square$ Yes 口 No Slze of gravel: ..................................

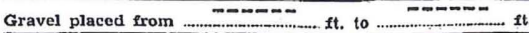

(10) LOCATION OF WTLL:

County Klamath Driller's well number

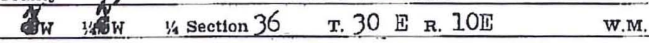

Bearing and distance from section or subdivision corner Approx. 350 feet South and 1200 feet Past of the North west corner of $S 36$ T $30 \mathrm{R}$ 10E

(11) WATER LEVEL: Completed gell.

Depth at which water was first found $78 \mathrm{x} \quad 78$ $\begin{array}{lll}\text { Static level } & 31 & \text { it. below land surface. Date/ } / 7 ? 7\end{array}$ Artesian pressure $-\cdots+\infty$ lbs. per square inch. Date (12) WELL LOG: Dlameter of well below casing ............................ Depth drilled $110 \quad$ ft. Depth of completed well $110 \quad \mathrm{ft}$.

Wormation: Describe color, texture, grain size and structure of materials; and show thickness and nature of each stratum and aquifer penetrated with at least one entry for each change of formation. Report each change in

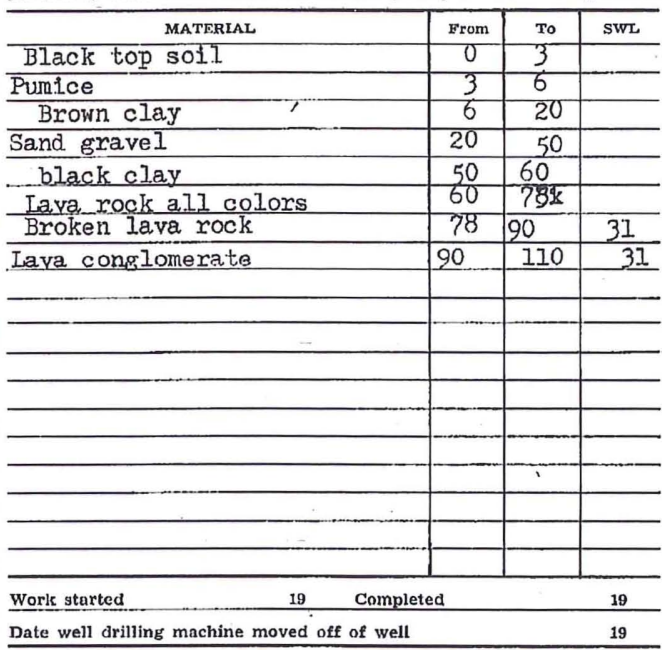

Drilling Machine Operator's Certification:

This well was constructed under my direct supervision. Materials used and information reported above are true to $\mathrm{my}$ best knowledge and belief. $197.7 .$.

Drilling Machine Operator's License No ... 201

\section{Water Well Contractor's Certification:}

This well was drilled under my jurisdiction and this report is true to the best of my knowledge and belief.

Name Wi.lson DRI I ling Contractro. Inc.

(Person, firm or corporation)
(Type or print) Address ........... Box 136, Merril1, Oregon 97633

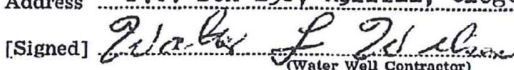

Contractor's License No 169 -..... Date July $5 \ldots \ldots \ldots . . . . . . . ., 19 ?$ ? 


\section{Area 2 Well Logs}

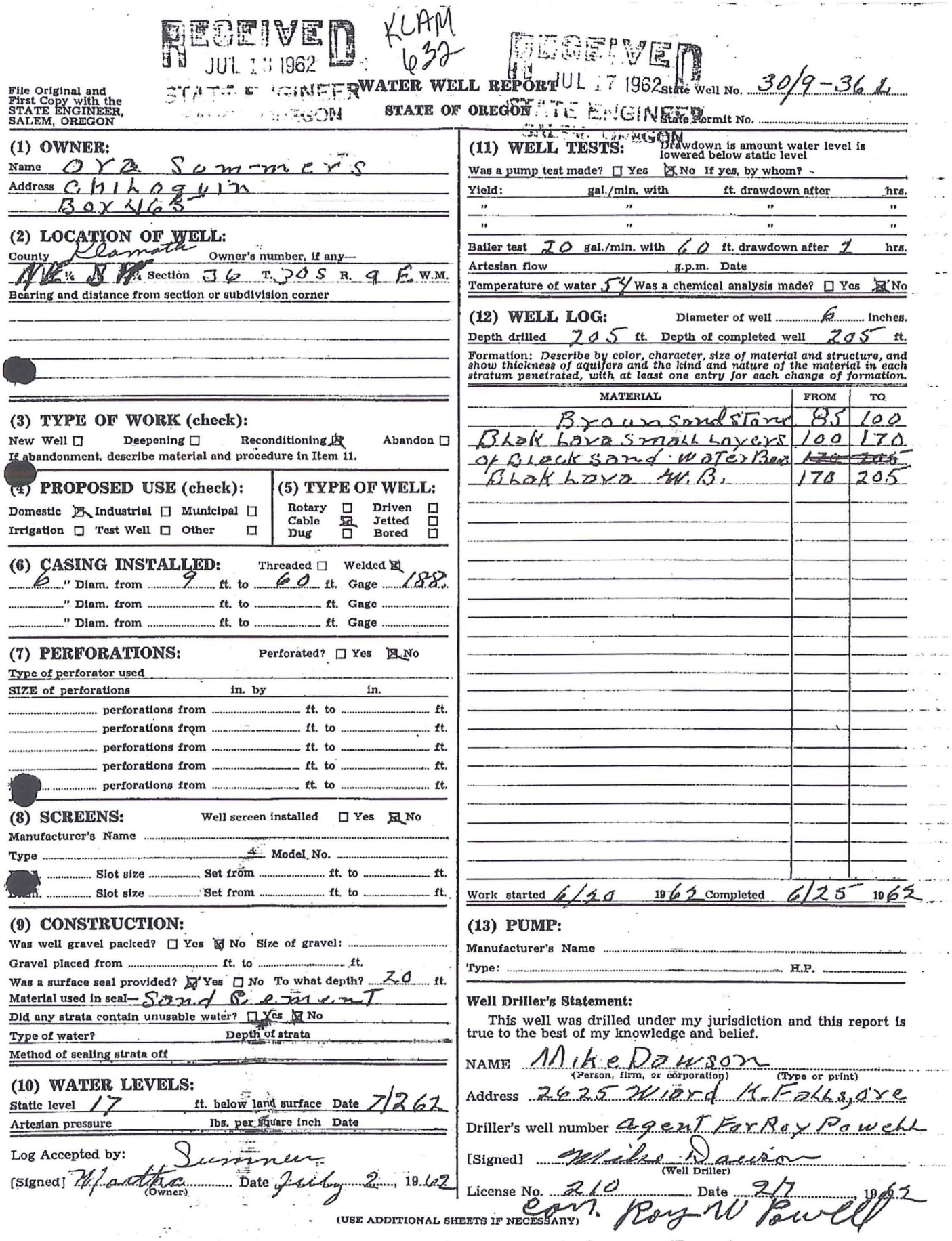


STATE ENGINEER

Salem, Oregon

$$
\begin{gathered}
\text { KUM } \\
\text { 6. }
\end{gathered}
$$

Well Record

OWNER: .........rine Summers

\section{MAILING}

ADDRESS:

CITY AND

LOCATION OF WELL: Owner's No.

STATE:

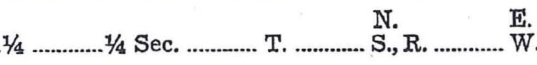

Bearing and distance from section or subdivision corner

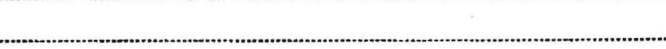

Altitude at well ...........4.5450

TYPE OF WELL: ..Drilled... Date Constructed

Depth drilled ....200 Depth cased

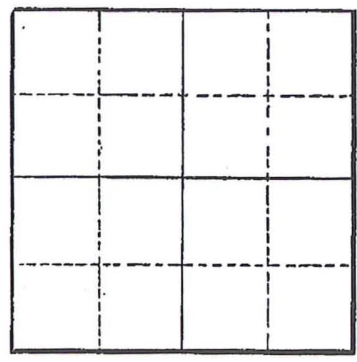

Section
STATE WELL NO. ....30/.9 -25P?

COUNTY ..KR Mmath

APPLICATION NO.

\section{CASING RECORD:}

6 inch

\section{FINISH:}

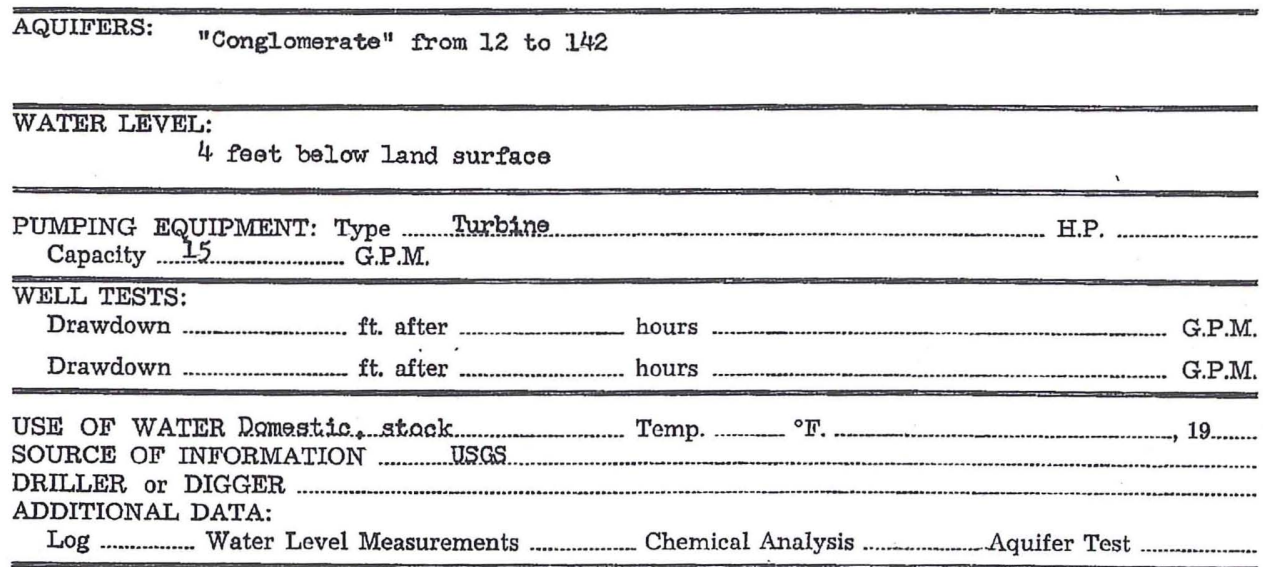
REMARKS:

Well penetrated pumice above aquifer and entered basalt at $142 \mathrm{ft}$.; owner has similar well $200 \mathrm{ft}$. west. 


\section{Area 3 Well Logs}

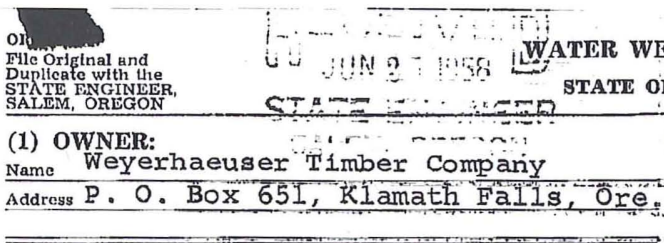

\section{(2) LOCATION OF WELL:}

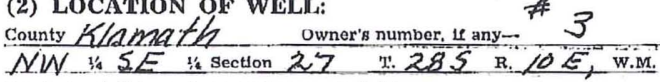
Bearing and distance froin sectlon or subdivislon corner

$N 50^{\circ} 30^{\prime} \mathrm{W}-247$ feet from southens corner of sec $23,7285, R$ R

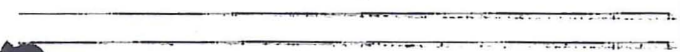

TYPE OF WORK (check):
New Well bo Deepening $[\mathrm{R}$ Reconditioning $\square$ Abandon $\square$ If abandonment, describe material and procedure in Item 11.

PROPOSED USE (check):
(5) TYPE OF WELL:
Rotary
Cable
Dug
(7) PERFORATIONS: Perforated? for fies $\square$ No Type of perforator used SIzE of perforalions $1 / 2 /$ in. by 5 in

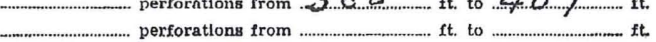

-... It. to

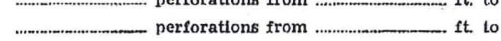

perforations from ........................ to to

SCREICNS: Well screen installed $\square$ Yes bTí

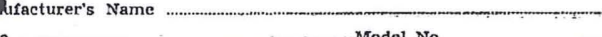

Type ........................... Model No.

Dlam. .............. Slot stze ................ Set from .................. ft. to _................ ft.

Stot size ................. Set from …….............. ft. to ……............. ft.

\section{CONSTRUCTION:}

Wars well gravel packed? tof Yes $\square$ No size of gravel: ....... 3 . "'

Gravel placed from ..... Z.P.

Was a surface seal provided? fores $\square$ No To what depth? 2.6 .0 . $\mathrm{sl}$. Material used in seal一.

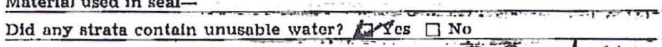

Type of water? Depth of strata $30 \%$ and 400 Method of sealing strata off coneres

(10) WATER LEVELS:

Static level ft. below land surface Date Arteslan pressure los. per square Inch Date

Log Accepted by:

(USE ADDITIONAL, SHEETS IF NECESSARY)
$K L A M$
562
$G-698$ state well No. $\begin{gathered}28 / 10-27 k \\ \text { state Permit No. } G-6 / 5\end{gathered}$

Drawdiown is amount water level is
lowered below static level

(11) WELL TESTS:
lowered below static leve

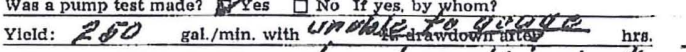
" \begin{tabular}{llll}
\hline Baller test & gal.min. with & ft. drawdown after & hrs. \\
Arteslan flow & g.p.m. & Date
\end{tabular} Temperature of water Was a chemical analysis made? $\square$ Xes 0 No

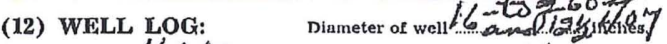
Depth drilled $40^{7} 7 \mathrm{ft}$. Depth of completed well $4 / 07 \mathrm{ft}$. Formation: Describe by color, character, size of material and structure, and
show thicleness of aquifers and the kind and nature of the material in each stratum penetrated, with at least one entry for each changs of formation.

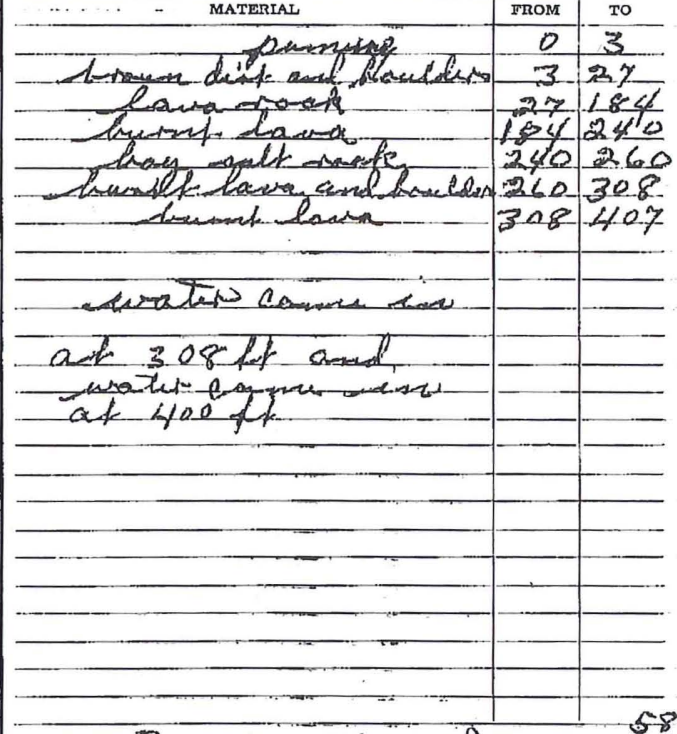

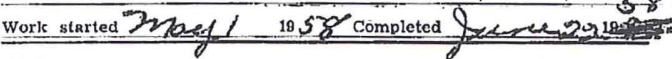

\section{(13) PUMP:}

Manufacturer's Name

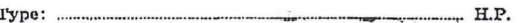

Well Driller's Statement:

This well was drilled under my jurisdiction and this report is true to the best of my knowledge and belief.

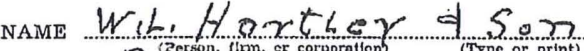
Address tow (Person, inm, or corvoration Driller's well number ........

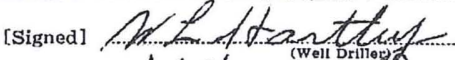

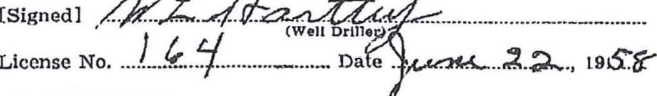


orrginal
Tyle original and

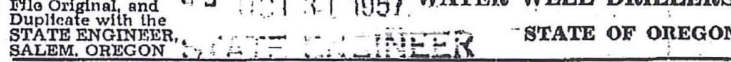

(1) OWNGR:

name Wayerbuevser 7 impor lo. address Hlamath Falls, Ore

(2) LOCATTON OF WELL:

county filasoses th Owner's number, ir any- Z R. T. D. or Stroot No.

Bearing and distance from section or subdivisfon corne

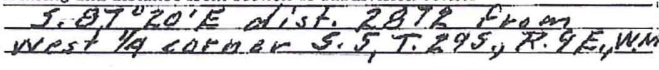

(3) TYPE OF WORK (check):

Nhw well 14 Deepening $\square \quad$ Recondittoning $\square \quad$ Xbandon $\square$ idonment, describe material and procedure in Item 11.

(1) PROPOSED USE (check): Domestic $\square$ Industrial \& Municipal $\square$ Irrigation $\square$ Test Well $\square$ Other

(5) EQUIPMENT: Rotary

Cable

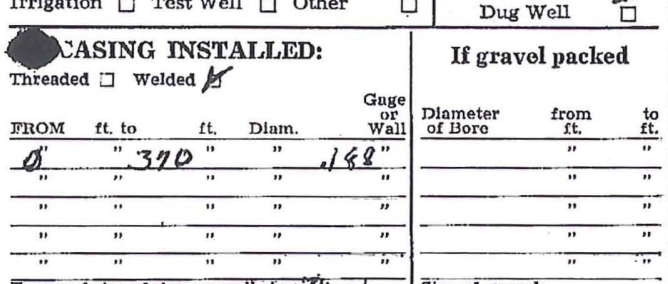

Type and size of shoe or well ring

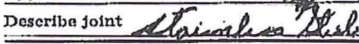

\section{(7) PERFORATIONS:}

Type of perforator used

sIze, of perforations ist in., length, by if FROM ft. to 330 ft. 370 perf per foot $\$$ No. of rows

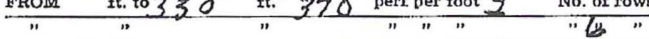

\begin{tabular}{|c|c|c|c|c|c|c|c|}
\hline " & $"$ & $"$ & 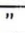 & $"$ & $"$ & "L & $"$ \\
\hline & $"$ & " & " & " & " & $"$ & if \\
\hline & " & $"$ & $"$ & $"$ & $"$ & $"$ & $"$ \\
\hline
\end{tabular}

\section{SCREIENS}

Glve Manufacturer's Name, Model No. and Sizo

\section{(8) CONSTRUCTION:}

Was a surface sanitary seal provided? 6 Yyes $\square$ No To what depth ft. Were any strata sealed agalnst pollution?

If yes, note depth of trata

$\begin{array}{lll}\text { If yes, note depth of strata } & \text { ft. to } & \text { ff. }\end{array}$

MITTHOD OT SEATTHE

(9) WATCIR LEVELS:

Depth at which water was ilrst found $3,60^{\circ}$

Standing level before perforating, 340

Standing level after perforating 340

Log Accepted by:

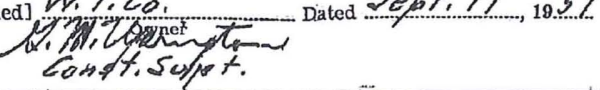

(10) WELL TESTS: KLAM 11773

Was a pump test made? Yes $\square$ No If yes, by whom?

\begin{tabular}{lccc}
\hline Yleld: & gal./min. with & ft. draw down after & hrs. \\
\hline is 50 & "Mone & $"$ " None
\end{tabular}

Artegian flow ....................................... 8.p.m.

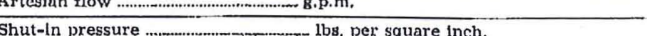

Baller test .................................. g.p.m. with ............................ St. drawdown

Temperature of water Was a chemical analysis made? $\square$ Yes $\square$ No Was electric log made of well? 7 Yes $\square$ No

(11) WELL LOG:

Dlameter of well, ..................... inches.

Total depth $380 \quad$ ft. Depth of completed well 380 ft. Formation: Describe by color, character, size of matertal and structure, and show thickness of aquifers and the kind and nature of the material in oach
stratum penetrated, with at least one enlry for each changs of formation.

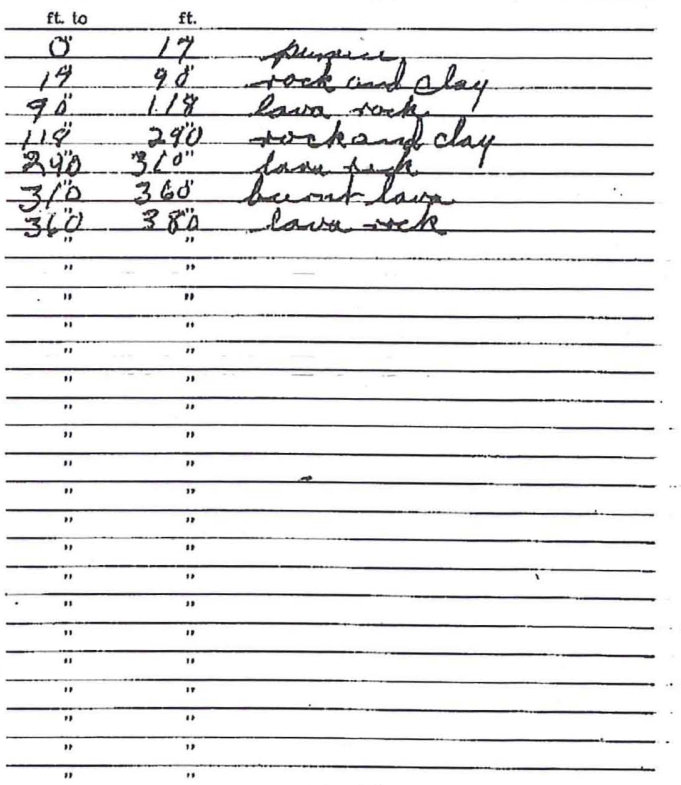

Ground clevation at well site ... $7 / 4,50$. feet abgve mean sea level,

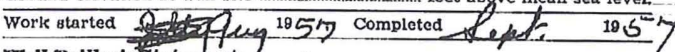

\section{Well Driller's 'statement:}

This well was drilled under my jurisdiction and this report is true to the best of my knowledge and bellef.

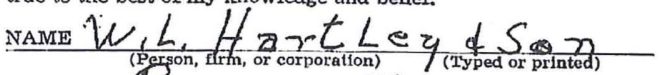

Driller's well pumber

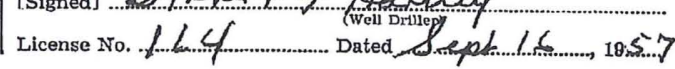


STATE OF OREGON

WATER SUPPLY WELL REPORT

(as required by ORS 537.765)

Instructions for completing this report are on the last pape of this form.

(1) OWNER:

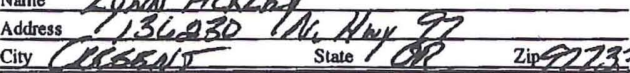

City PRSEALT

E New Well $\square$ Deepening $\square$ Alteration (repair/recondition) $\square$ Abandonment

(3) DRILL METHOD:

Q Rotary Air $\square$ Rotary Mud $\square$ Cable $\square$ Auger

Oother

(4) PROPOSED USE:

Domestic $\square$ Community $\square$ Industrial $\square$ Irrigation

D) $\square$ Thermal $\square$ Injection $\square$ Livestock $\square$ Ohher

(5) BORE HOLE CONSTRUCTION:

Special Construction approval $\square$ Yes 1 No Depth of Completed Welf 205 Explosives used $\square$ Yes $\square$ No Type HOLE SEAL

Dismeter, From To Material From To Secks orpounds

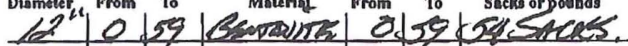

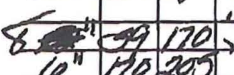

How was seal placod:

How was seal placed: Mothod
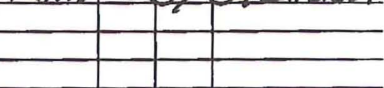

(17) Other Len

Revess Dev

- It. $10=$ fi. Material

from to $\mathrm{ft}$. Size of gravel

(6) CASING/LINER:

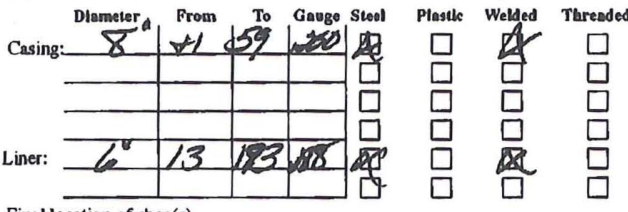

Final location of shoe(s)

7) PERFORATIONS/SCREENS

$\begin{array}{ll}\text { ADPerforations } & \text { Method } \\ \square \text { Screens } & \text { Typoc } \mathrm{SCO} \text { Material }\end{array}$

From To Slot Nele/plpe

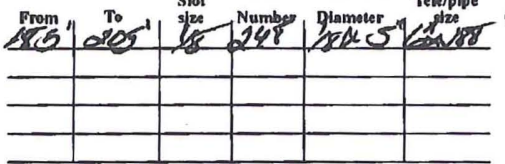

(8) WFLL TESTS: Minimum testing time is 1 hour

\begin{tabular}{|c|c|c|c|}
\hline$\square$ Pump & $\square$ Bailer & $\Delta J_{\text {Air }}$ & $\begin{array}{c}\text { Flowing } \\
\square \text { Artesian }\end{array}$ \\
\hline Yleld goU milu & Drawdown & Drull stem at & Time \\
\hline lowbery & LRK NenN & $2100^{\prime}$ & $1 \mathrm{hr}$ \\
\hline & & & \\
\hline
\end{tabular}

Temperature of water $4 /{ }^{\circ}$ Depth Artesian Flow Found

Was a water analysis done? $\square$ Yes By whom

Did any strata contain water not suitable for intended use? $\square$ Too little

$\square$ Salty $\square$ Muddy $\square$ Odor $\square$ Colored $\square$ Other

Depth of strata:

ORIGINAL - WATER RESOURCES DEPARTMENT FIRST COPY - CONSTRUCTOR SECOND COPY - CUSTOMER
WELL I.D. \#LE2 298

START CARD \# LIST28

(9) LOCATION OF WELL by legal description:

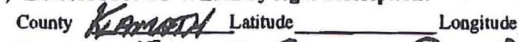

Township 29 or Range or W. WM.

Section $12 B$ DE $1 / 4$

Tax Lot $3 \mathrm{SOCO}$ Lot Block Subdivision

Street Address of Well (or nearest address) Luesenegen

(10) STATIC WATER LEVEL:

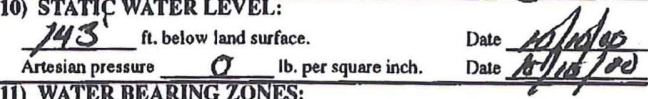

(11) WATER BEARING ZONES:

Depth at which water was first found

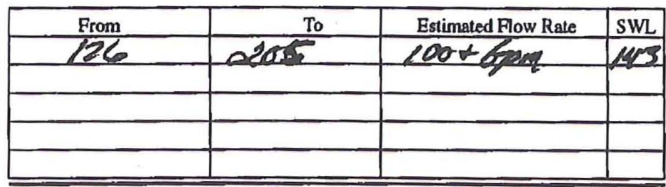

(12) WELL LOG:

Ground Elevation

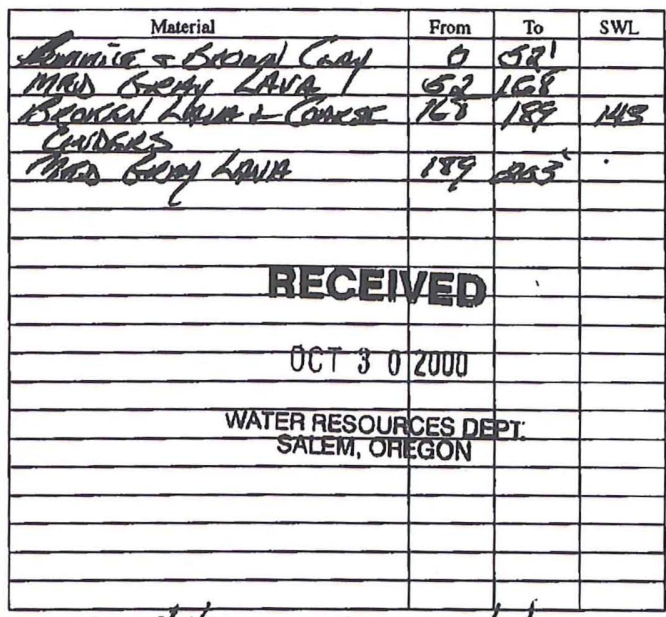

Date starled $15 / 5 / 00 \quad$ Completed $10 / \mathrm{h} / \mathrm{ha}$ (unbonded) Wat Well Constructor Certification:

I certify that the work I performed on the construction, alteration, or abandonment of this well is in compliance with Oregon water supply well construction standards. of my knowledge

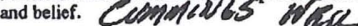
A wwC Number 447.2267 Date (bonded) Water Well Constructor Certification:

I accept responsibility for the construction, alteration, or abandonment work performed on this well during the construction dates reported above. All work performed during this time is in compliance with Oregon water supply well
construction standards. This geport is.tmate the best of my knowledge and belief.

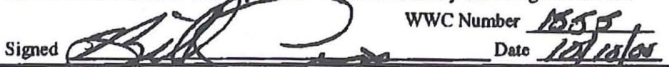




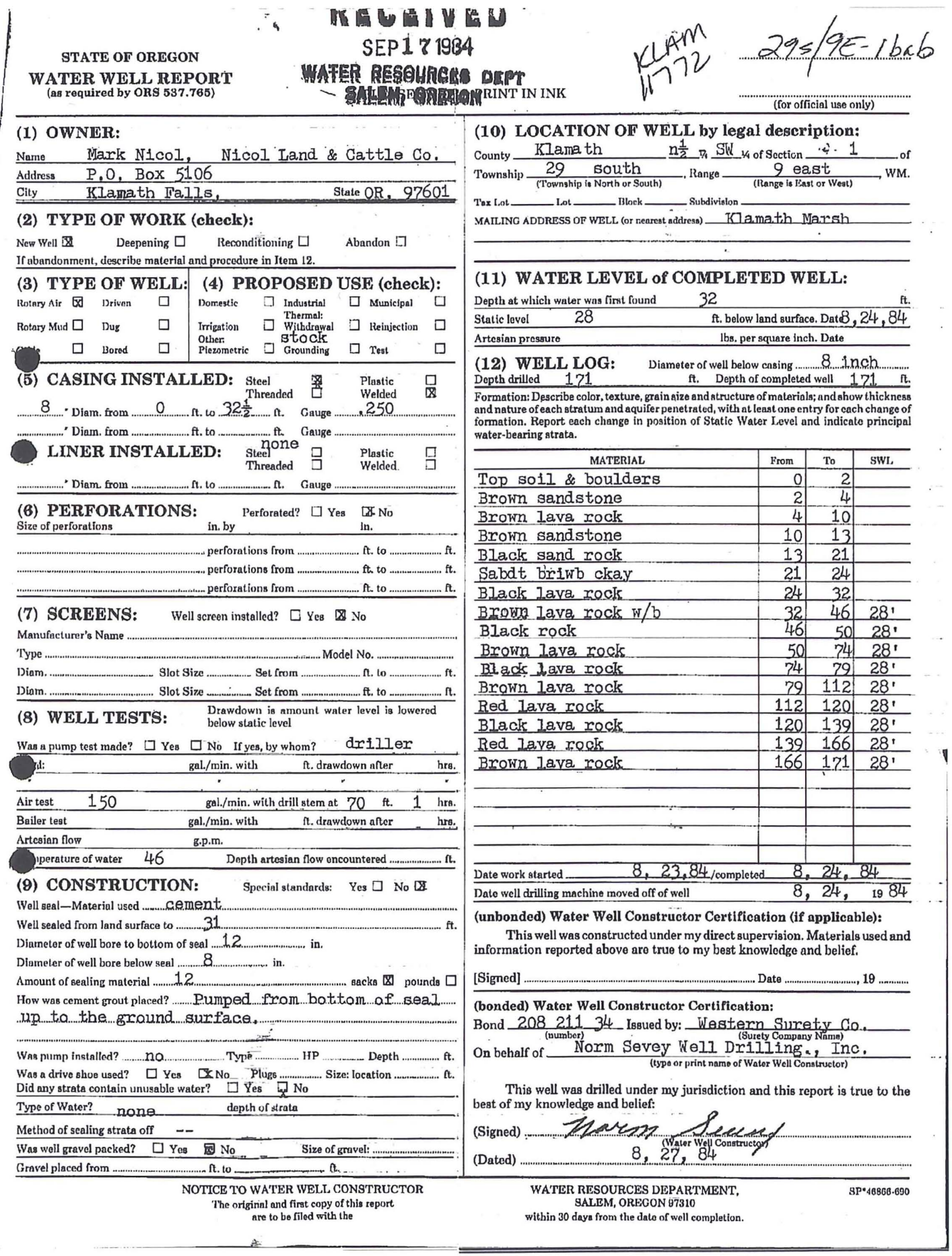




\section{Area 4 Well Logs}

Wixt $\begin{gathered}\text { STATE OF OREGON } \\ \text { WATER WELL REPORT } \\ \text { (eas required by ORS 537.765) }\end{gathered}$

(1) OWNER:

Name Olenen mathis

Addres PO EoX Hill

City Fort R. Tamath state Dr: zip (2) TYPE OF WORK:

Now Well $\square$ Deepen $\square$ Recondition $\square$ Abandun

(3) DRILI METHOD

$\square$ Rulary Air $\square$ Rotary Mud $\square$ Cable

$\square$ Oher

(4) PROPOSED USE:
$\square$ Domeatic $\square$ community $\square$ Industrial $\quad \square$ Irrigativn

$\square$ Thermal $\quad \square$ Injection $\square$ other

(5) BORE HOLE CONSTRUCTION:

Special Construction approval Yes No- Depth of Completed Well 3010 Explosives used $\stackrel{\text { Yes }}{\square} \stackrel{\text { No }}{\square} \square^{\square}$ Type $\longrightarrow$ Amuunt

HOLE AmenL Amunt

Diameter From To

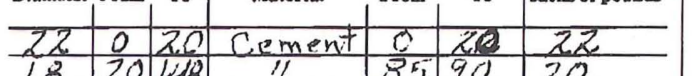

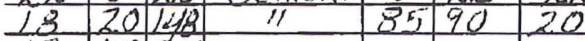

1214830

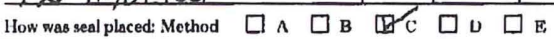

Other

Backill placed from _ ft. to — $\mathrm{ft}$. Material

Gravel placed from _ ft. to _ ft. Size of gravel

(6) CASING/LINER:

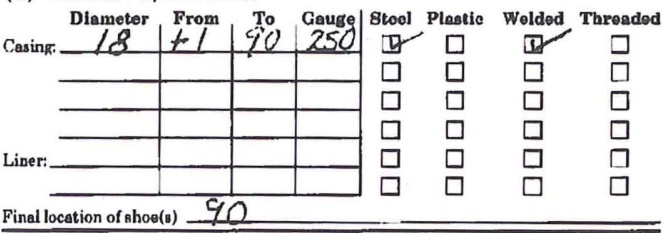

(7) PERFORATIONS/SCREENS;

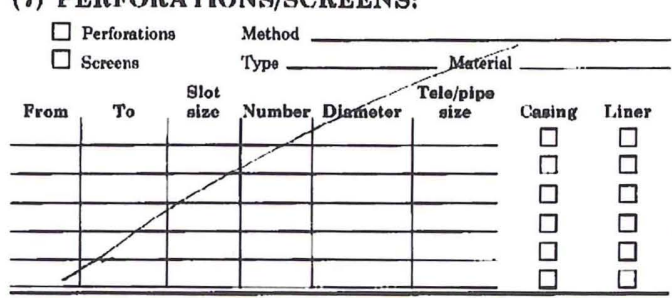

(8) WELL TESTS: Minimum testing time ir 1 hour.

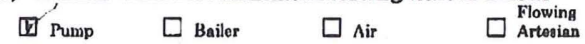

\begin{tabular}{l|l|l|l}
\hline 1000 & Aा & & (1hi) \\
\hline & & & \\
\hline
\end{tabular}

Temperature of water $4 Z^{\circ}$ Depth Artosian Flow Found

Was a water analysis done? NO $\square$ YoB By whom

Did any atrata contain water not suitable for intendgd use? $\square$ 'Too jiftle

$\square$ Salty $\square$ Muddy $\square$ odor $\square$ colored $\square$ Other SurfAce

Depth of atrata: 10

ORIGINAL \& PIRST COPY · WATER RESOURCES DEPARTMENT
(START CARD) \#235\%

(9) LOCATION GF WELL by legal description:

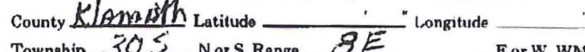

Township 305 Nor S, Range $8 E$ Eor W. WM.

Section $14 \quad N 12 \% 5 \%$

Tax Lot_L Lot__ _ Block__undivision

Streot $\uparrow$ ddress of Well (or nearest address) Mnthis Eninch moilitani lirossing Rel.

(10) STATIC WATER LEVEL:

11.5 ft. below land surface.

Date $62 / 1|/ \bar{y}|$

Artesian pressure $\longrightarrow$ lb. per square inch. Date (11) WATER BEARING ZONES:

Depth at which water was first found

\begin{tabular}{|c|c|c|c|}
\hline From & Tn & Eatimated Flow Rate & swL \\
\hline 10 & 58 & 56 & 10,5 \\
\hline 150 & 300 & 4000 & 10,5 \\
\hline & & & \\
\hline & & & \\
\hline
\end{tabular}

(12) WELL LOG:

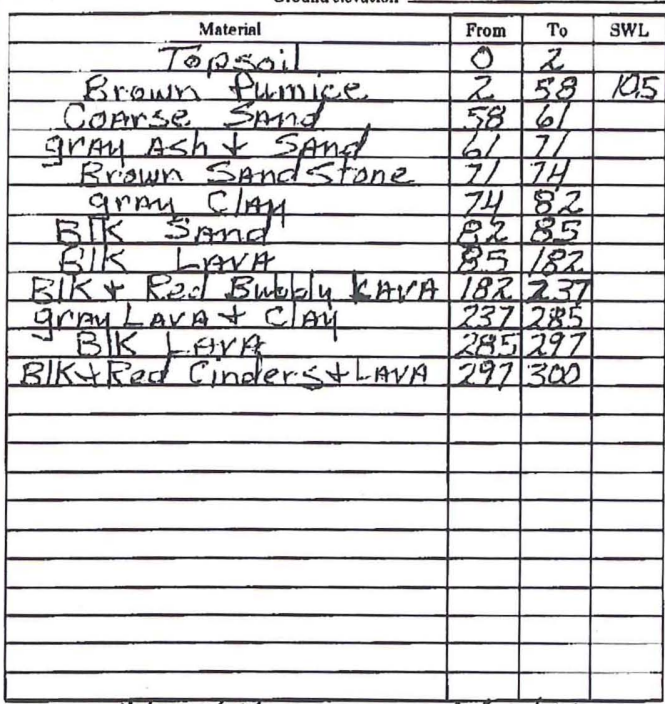

Date started $4 / 20 / 51$ Completed 67119 (unbonded) Water Well Constructor Certificution:

I certify that the work I performed on the construction, alteration, or abandonment of this well is in compliance with Oregon well construction gtandards. Materials used and information reported above are true to my best knowledge and belief.

Signed

WWC Number

(bonded) Water Woll Congtructor Certification:

I accept responsibility for the construction, alteration, or abandonment work performed on this well during the construction dates reported above. al work performed during this time is in compliance with Oregon well construction standards. This report is true to the best of my knowledge and belief.

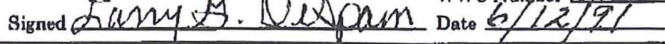




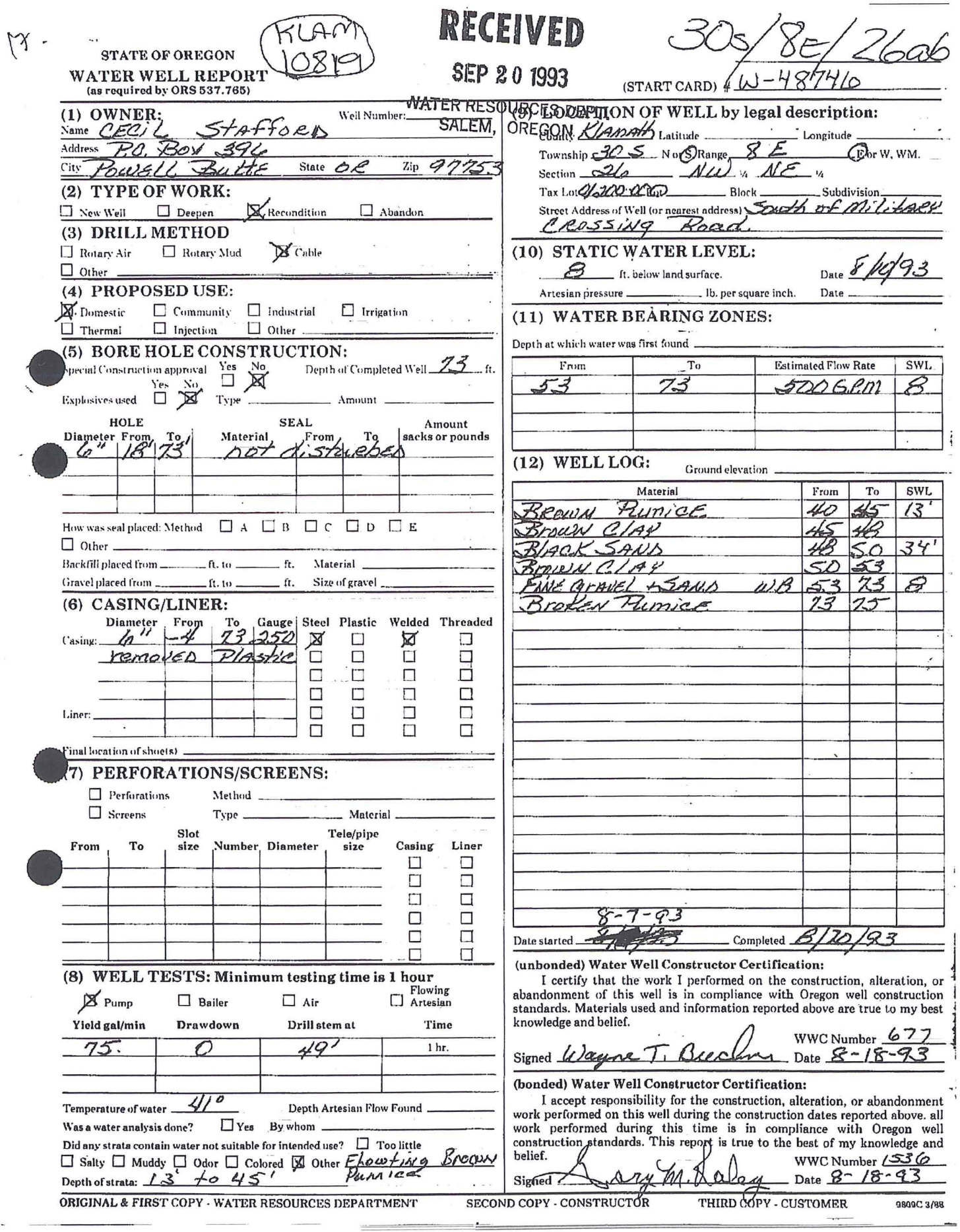




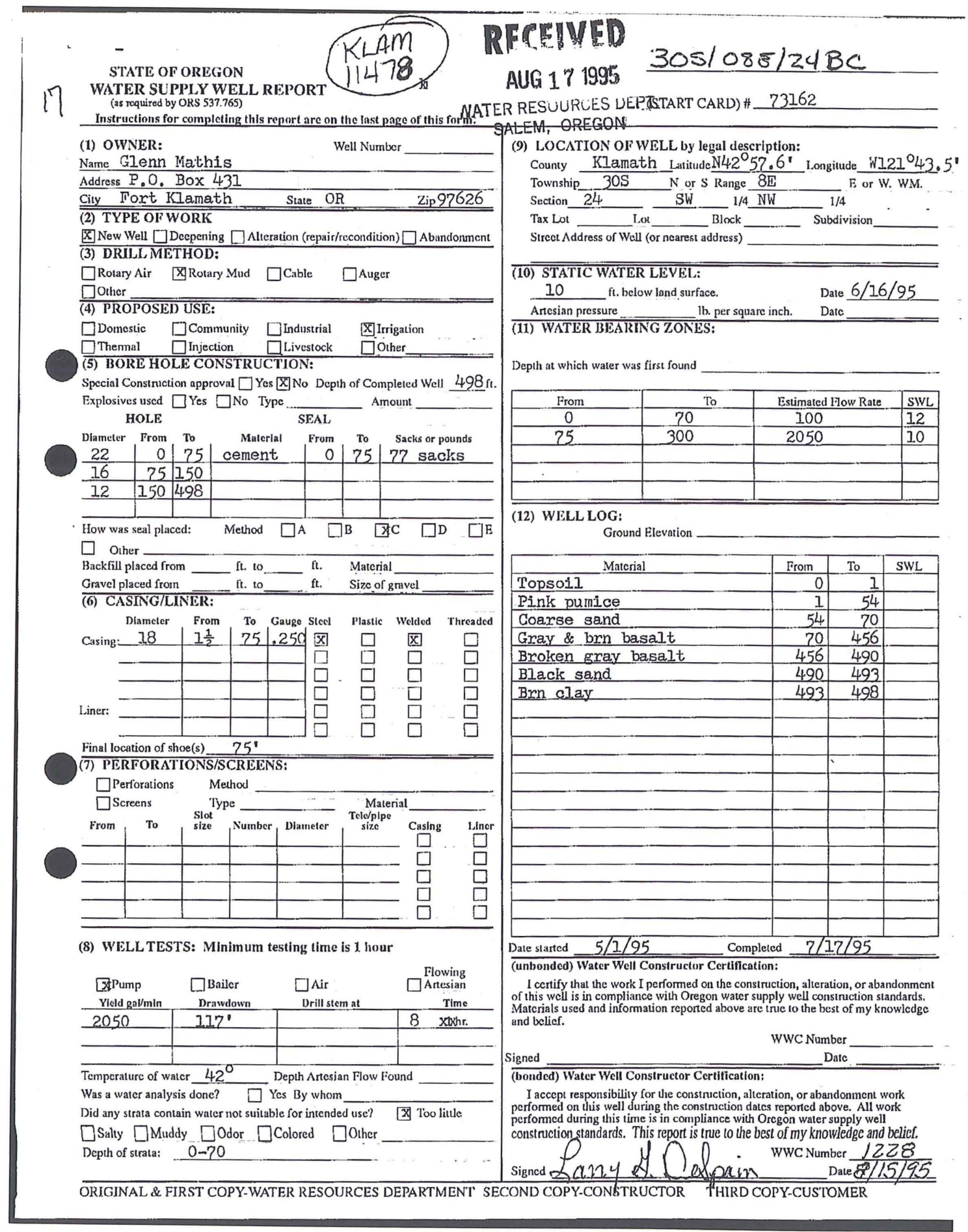




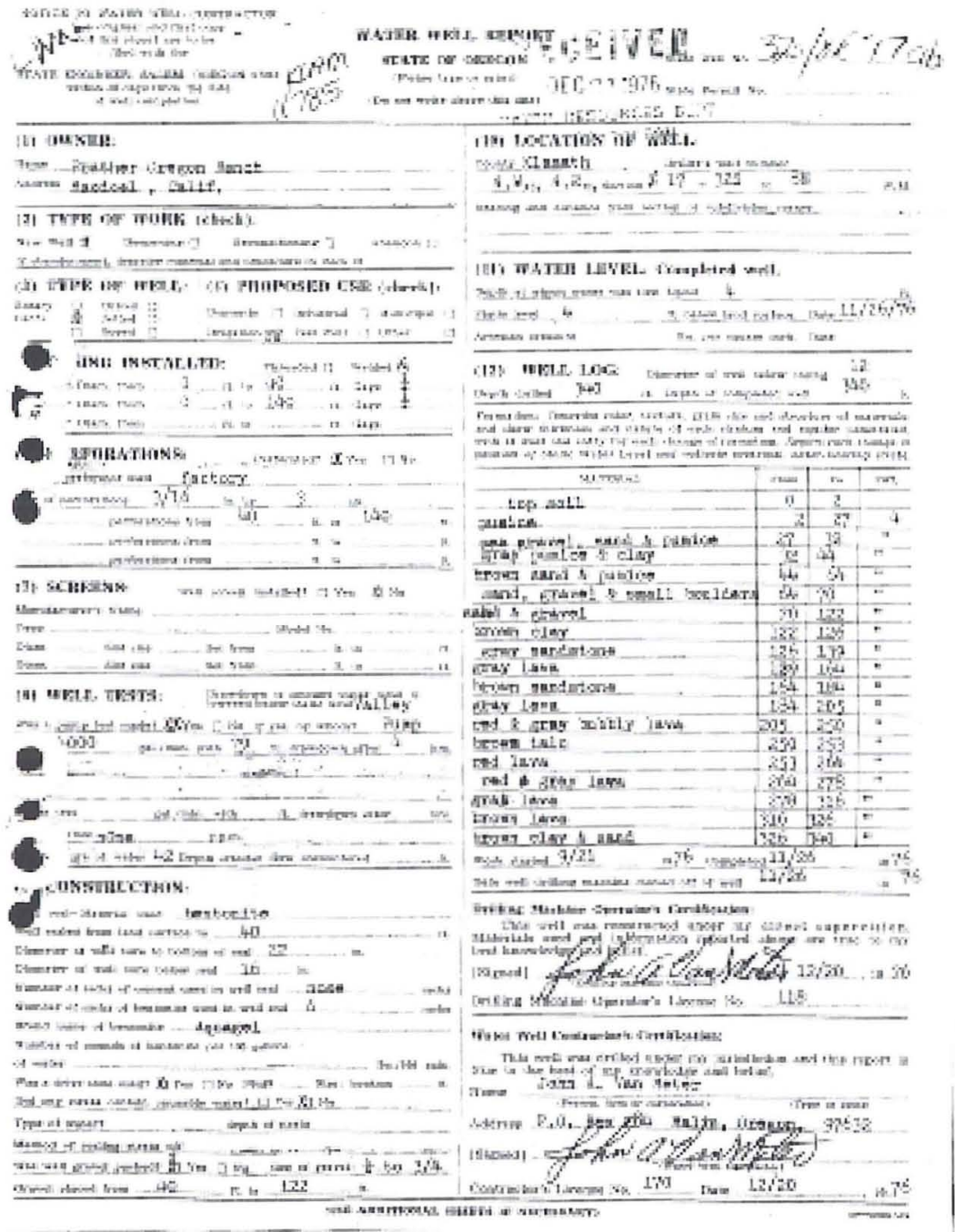




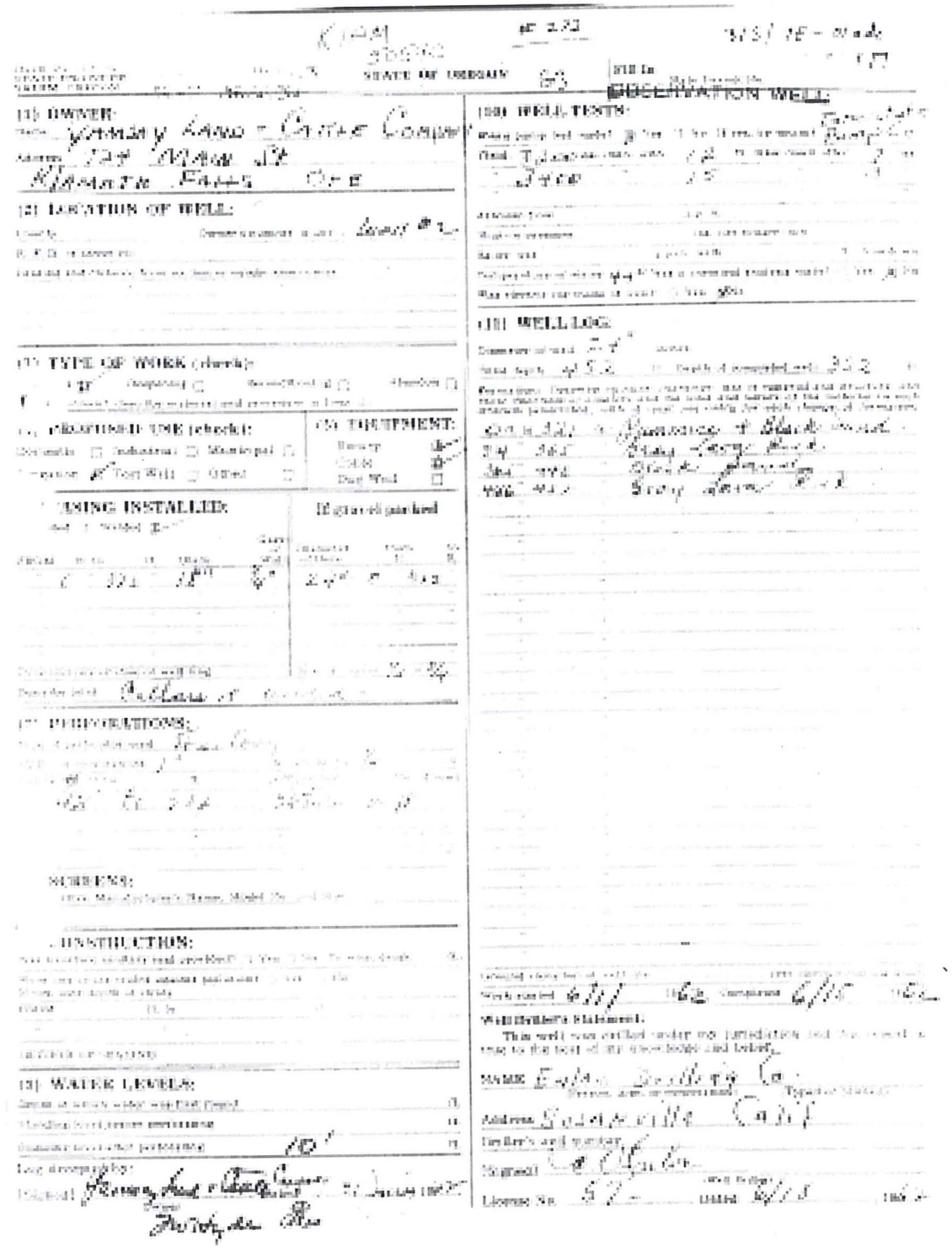




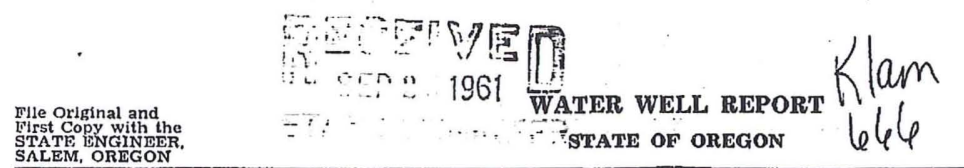

(1) OWNER:

Name Saxanah Land Go

Address P. O. Box 7089

Klamath Falls, Oregon

(2) LOCATION OF WELL:

County Klamath Owner's number, if any-

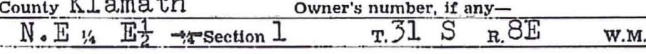

Bearing and distance from section or subdiviston corner

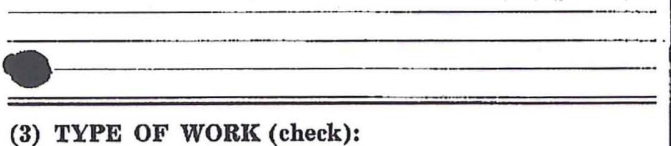

If abandonment, describe material and procedure in Item 11.

( - PROPOSED USE (check):

Domestic $\square$ Industrial $\square$ Municipal $\square$

Irrigation $\uparrow$ Test Well $\square$ Other

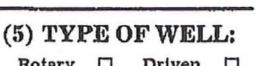

Rotary
Cable 㽞 $\begin{gathered}\text { Driven } \\ \text { Jetted }\end{gathered}$

(6) CASING INSTALLED: Threaded $\square$ welded

1.2...." Diam. from ..... O .......... ft. to ...161...... ft. Gage ........

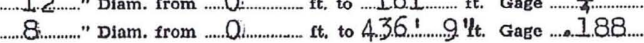
...................." Diam. from ....................... ft. to ....................... ft. Gage ...................... (7) PIGRFORATIONS: Perforated?

Type of perforator used toredz

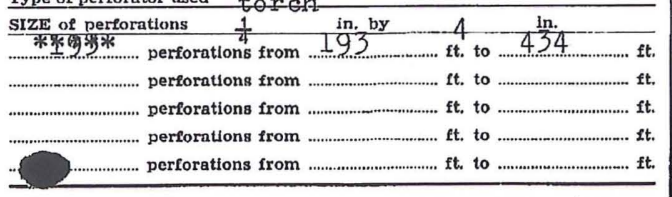

(8) SCREENS: Well screen Installed $\square$ Yes 臬 No

Manufacturer's Name ..................................................................................................

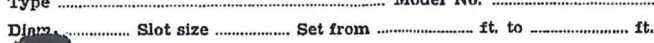

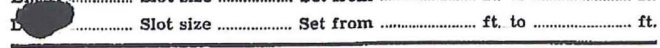

(9) CONSTRUCTION:

Was well gravel packed? $\square$ Yes w No slze of gravel: .

Gravel pluced from .................................. ft. to ............................... ft.

Was a surface seal provided? 9 Yes $\square$ No To what depth? ............. ft. Material used in seal-drove in to clay

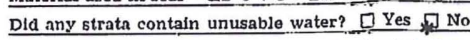

Type of water? Depth of strata

Method of seallng strata of

(10) WATER LEVELS:

Static level $0 \quad$ It. below Tand surface Dateg/21/61 Irtesian pressure $1 \frac{1}{2} \quad$ bs. per square inch Date $9 / 21 / 61$

pg Accepted by:

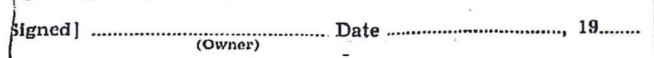

(11) WELL TESTS: Drawdown is amount water lcvel is

Was a pump test made? 口 Xes 9 No If yes, by whom?

Yleld: $\quad$ gal./min, with ft. drawdown after $\mathrm{hrs}$

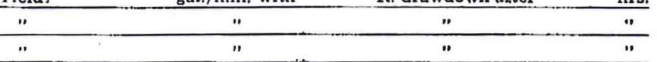

Bailer test $275 \mathrm{gal} / \mathrm{min}$, with 3 ft. drawdown after $30 \mathrm{minh}$ irs. Artesinn flow $120 \quad$ g.p.m. Date $9 / 21 / 67$ comint Temperature of water. 42 Was a chemical analysts made? $\square$ Yes 매은

(12) WELL LOG: Dlameter of well 12 ........................ inches. Depth drilled 462 ft. Depth of completed well 462 ft. Formation: Describe by color, character, size of material and structure, and show thickness of aquiters and the leind and nature of the material in each
stratum penetrated, with at least one entry for each change of formation. \begin{tabular}{c|c|c|}
\hline \hline MATERIAL & FROM & TO
\end{tabular}

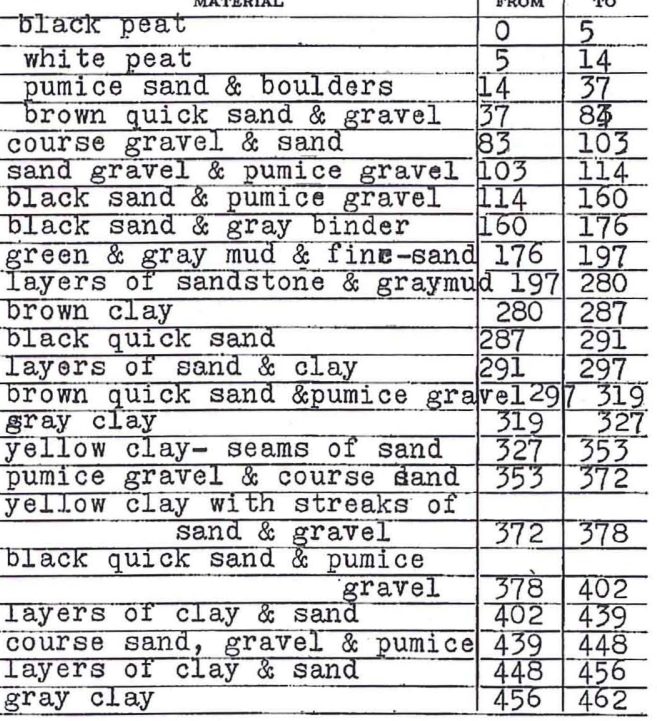
\begin{tabular}{l|l|l}
\hline gray clay & 456 & 462 \\
\hline
\end{tabular}

\section{(13) PUMP:}

Manufacturer's Name

Type: ................................................................................ H.P. ..........................

\section{Well Driller's Statement:}

This well was drilled under my jurisdiction and this report is true to the best of my knowledge and belief.

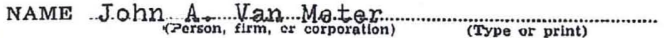

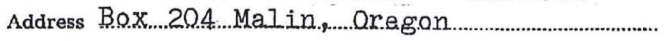

Driller's well number

(USE ADDITIONAL SHEETS IF NECESSARY)

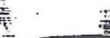


Ne

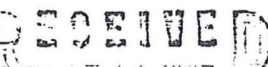

NOTICE TO WATER WELL CONTRACTOR, $-\bar{i}$ i 3 i 37

The orlginal and first copy
of this report are to be
filed with the

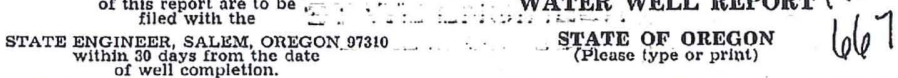

(1) OWNER:

Name H.W. Tompkins

Address P.O. Bax 578

Chiloquin, oregon

(2) LOCATION OF WELL:

CountyKI amath D. Driller's well number

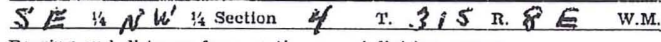
Bearing and distance from section or subdiviston corner

\section{(3)}

(3) TYPE OF WORK (check):

Nerk Well $\square$ Deepenine $\square \quad$ Reconditioning $\square \quad$ Abandon $\square$ andonment, describe material and procedure in Item 12.

(4) PROPOSED USE (check): $\quad$ (5) TYPE OF WELL: Domestic $\square$ Industrial $\square$ Municipal $\square$ Rotary $\square$ Driven $\square$

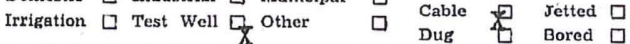

(6) CASING INSTALLED: Threaded $\square$ welded

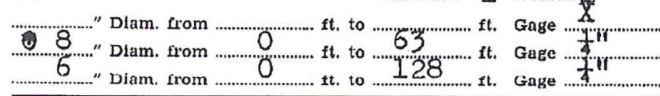

(7) PERFORATIONS: Perforated? $\mathscr{X}$ Yes $\square$ No

Type of perforator used torch

Size of perforations $\frac{1}{4} \quad$ in. by 4 in.

4....per......torforations from 108 in,

............................... perforations from ............................... ft. to ............................. ft.

........................... perforations from .............................. ft. to

….......... perforations from . ……................ ft. to

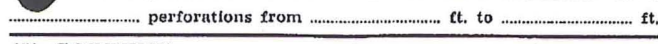

(8) SCREENS: Well screen installed? $\square$ Yes No

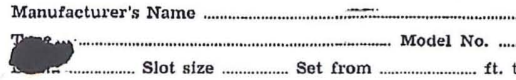

Diam. Slot size set from

(9) CONSTRUCTION:

Well seal-Materlal used in seal .... benthonite

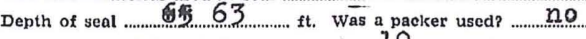

Diameter of well bore to bottom of seal ....................... in.

Were any loose strata cemented off? $\square$ Yos 药 No Depth

Was a drive shoe used? $\mathrm{T}$ Yes $\square$ No

Was well gravel packed? $\square$ Yes $\chi^{\square}$ No size of gravel:

Gravel placed from ……..................... ft. to .......................... ft.

Did any strata contain unusable water? $\square$ Yes $Q$ XNo

Type of water? depti of strata

Method of sealing strata off

(10) WATER LEVELS:

Static level ft. below land surface Date

Artesian pressure $5 \quad$ lbs. per square inch Date $10 / 6167$

11) WELL TFSTS:

Was a pump test made? $\square$ Yes $\square$ No If yes, by whom?

Yicld: $\quad$ gal. $/ \mathrm{min}$. with ft. drawdown after hrs.

" " "

Bailer test gal./min. with ft. drawdown after hrs.

Arteslan flow $1.2 \frac{1}{2} \quad$ g.p.m. Date $10 / 67 / 67$

Temperature of water 51 Was a chemical analysis made? $\square$ Yes $[$ No

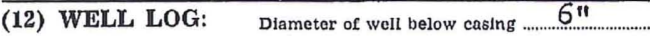

Depth drilled 1.31 ft. Depth of completed well 1.31 ft.

Formation: Describe by color, character, size of material and structure, and show thickness of aquifers and the kind and nature of the material in each MATrRIAL so

pumic

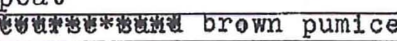

course sand

white pumice \& sand

course sand \& gravel

fine sand \& white pumice

layers of hard \& soft brow

brown sandstone

brown sand, yellow pumice

layers of hard \& soft sand

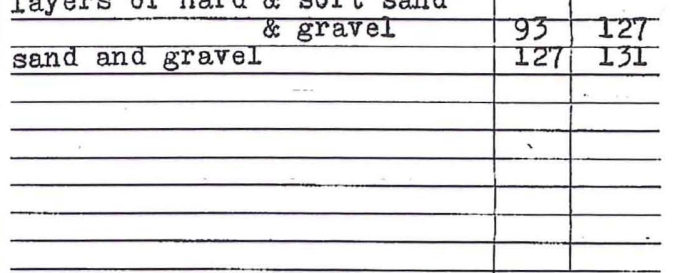

Work startod $9 / 26 \quad{ }_{10}^{67}$ Completed $10 / 6 \quad{ }_{19}^{67}$

Date well drilling machine moved off of well 10/6 197

(13) PUMP:

Manufacturer's Name

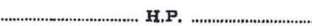

Water Well Contraotor's Certifloation:

This well was drilled under my jurisdiction and this report is true to the best of my knowledge and belief.

NAME John A. Van Meter

Address Bax...20.4......Mal.in,....Oregan

Drilling Maching Operator's License No. ..........17 8

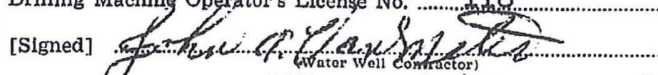

Contractor's License No. ...170 ..... Date ..................... 19.......

- - (USE ADDITIONAL SHEETS IF NECESSARY) 


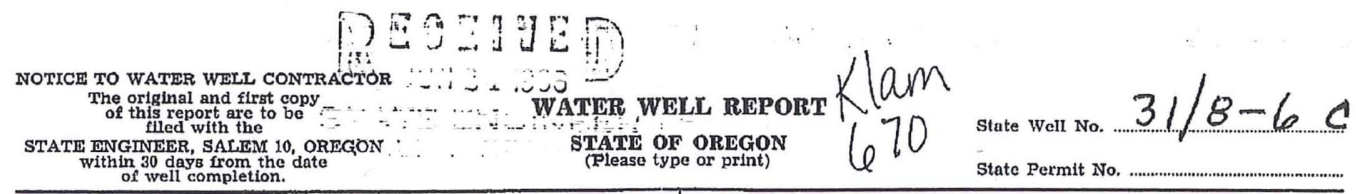

(1) OWNER:

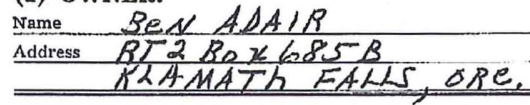

(2) LOCATION OF WELL:

county KLAMATh Driller's well number

NE $3 N W$ ia Section 6 T. $3 / S$ R. $8 E$ W.M. Bearing and distance from section or subdivision corner

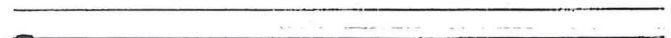

(3) TYPE OF WORK (check):

Now Well If Deepening $\square$ Reconditioning $\square$ Abandon $\square$ bancionment, describe material and procedure in Item 12.

(4) PROPOSED USE (check): Domestic $\square$ Industrial $\square$ Municipal $\square$ Irrigation Test Well $\square$ Other

(5) TYPE OF WELL: Rotary 마 Driven $\square$ Cable 范 Jetted

(6) CASING INSTALLED: Threaded $\square$ Welded $\not 2$ 20........" Diam. from ................ st to ...2. $76^{\prime \prime}$.... th Gage $2.5-0$ 1.-3 "Diam. from ……............ ft. to .................. st. Gage

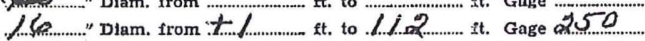
(7) PERTORATIONS: Perforated? KXyes $\square$ No Type of perforator used EACTORY SLOT Size of perforations //y in. by 2 in.

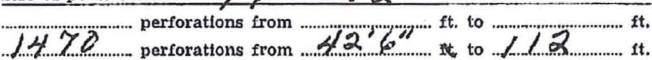

............................. perforations from .............................. ft. to

D..................... perforations from ................................ ft. to perforations from

.... ft. to

(8) SCREENS: Well sereen installed? $\square$ Yes $\quad$ No

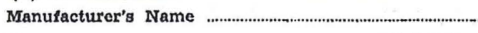

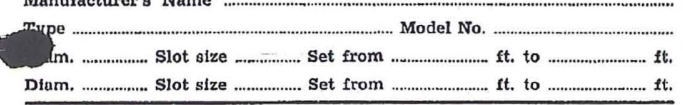

(9) CONSTRUCTION:

Well seal-Material used in seal ......NWGRTe Y BeNTionite Depth of seal ....20 ft. Was a packer used? .NO Diameter of well bore to bottom of seal ....2................. in Were any looso strata cemented off? $\square$ Yes No Depth . Was a drlve shoe used? $\not$ Yes $\square$ No

Was a drlve shoe un

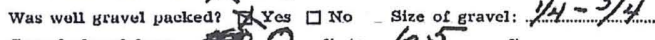
Gravel placed from ... 0 . 0 ft. to ....

Dld any strata contain unusable water? $\square$ Yes b W No Type of water? Depth of strata Method of sealing strata off

(10) WATER LEVIGLS:
Static level 5 ft. below land surface Date $5 / 2$ y/6 6 Artesian pressure
(11) WELL TESTS: Drawdown is amount water level is Was a pump test made? J Yes $\square$ No If yes, by whom?VALhey puMys Yield: $\quad$ gal./min. whth $\quad$ ft. drawdown after.. \begin{tabular}{llll}
\hline$"$ & $"$ & $"$ & \\
\hline Bailer test & gal./min. with & ft. drawdown after & hrs. \\
\hline
\end{tabular} Artesian flow g.p.m. Date

Temperature of water $/ / 3$ was a chemical analysis made? $\square$ Xes $\quad$ No

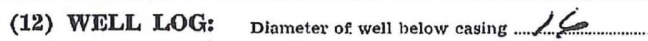
Depth drlled 274 it. Depth of completed well 2 z $7 / 4$ ft. Formation: Describe by color, character, size of material and structure, and show thickness of aquiflers and the kind and nature of the matrialure, in each
stratum penetrated, with at least one entry for each change of formation. \begin{tabular}{c|l|l}
\hline \hline MATERIAL & I'ROM & TO
\end{tabular} Z $-$

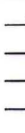
YekLow daY F PUMICE Yenbow a $24 y$ PUMICE $B A A C K C, N d e r s$

yedhowehAhk

BROUN $2 A$ WA GAAYBASALT BeWLbERS 132 L32 BRowN SAKA 132146

$G B A Y B A S A C Y$

GREEN SAALE

GRAY BASALT

BRO WN A V VA

$B R O K e N B K A C N$ LAKA 200 244

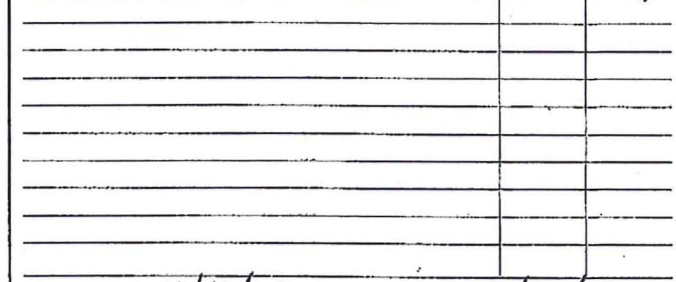

Work started $4 / 36 / 6619$. Completed $5 / 25 / 6 / 619$ Date well drilling machine moved of of well $5 / 3 y / 66$ (13) PUMP:

Manufacturer's Name

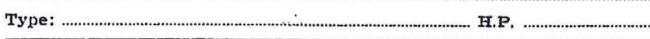

Water Well Contractor's Certification:

This well was drilled under my jurisdiction and this report is true to the best of my knowledge and belief.

NAME E E STOREY

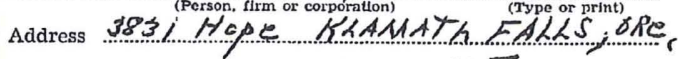

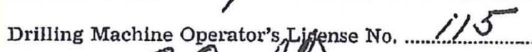

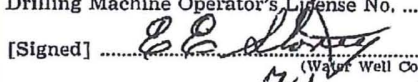
Contractor's License No. Ay (Wyar well contracior. 


\section{Area 5 Well Logs}
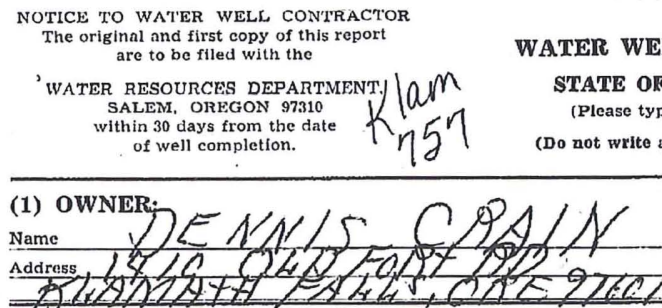

(2) TYPE OF WORK (check):

New Well $\square$ Decpening $\square$ Reconditioning of Abandon $\square$ If abandonment, describe materinl and procedure in Item 12.

\begin{tabular}{|c|c|c|}
\hline $\begin{array}{l}\text { (3) TYPE } \\
\text { Rotary } 8 \mathrm{O} \\
\text { Crye }\end{array}$ & $\begin{array}{l}\text { OF WELL: } \\
\text { Driven 무 } \\
\text { Jetted } \square \\
\text { Bored } \square\end{array}$ & $\begin{array}{l}\text { (4) PROPOSED USE (check): } \\
\text { Domestic } \square \text { Industrial } \square \text { Municipal } \\
\text { Irrigation } \square \text { Test Well } \square \text { other }\end{array}$ \\
\hline
\end{tabular}

(5) CASING INSTAKLED: Threaded $\square$ welded $\square$

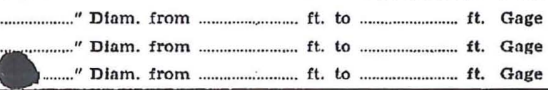

(6) PERFORATIONS: Perforated? $\square$ Yes $\square$ No.

Type of perforator used

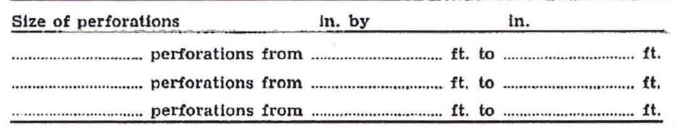

(7) SCREIENS:

Well screen installed? $\square$ Yes $\square$ No

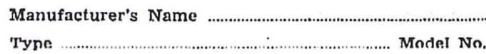

Tyne
Dlam. ................. Slot size ................ Set from ...................... ft. to ........................ ft.

Diam. Slot size Set from to

(8) WICLL TESTS: $\begin{aligned} & \text { Drawdown is amount water level is } \\ & \text { lowercd below static level }\end{aligned}$

urng a pumn test made? $]$ Yes.믄 If yes, by whom?

acld: $\quad$ al. $/ \mathrm{min}$. with ft. drawdown after hrs. "

8ntap test 20 gal./min. with 55 t. drawdown after $/$ hrs.

sian flow g.p.m.

Temperature of water Depth artesian flow encountered

(9) CONSTRUCTYON:

Well senl-Material used.

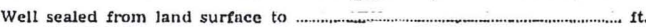

Diameter of well bore to bottom of seal ............................... in

Dlameter of well bore below seal ........................... in.

Number of sacks of cement used in well seal .......................................... sacks

How was cement grout placed?

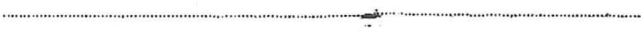

Was a drive shoe used? Yes $\square$ No Plugs $\square$ Size: location .......... ft.

Did any strata contain unusable water? $\square$ Yes $\square$ No

Type of water? _._. depth of strata

Method of sealing strata off

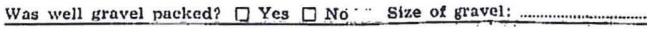

Gravel placed from ....................... ft. to ..................... $\mathrm{ft}$.
E.

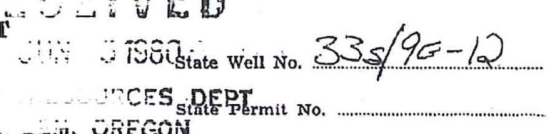

(10) LOCATION OF WELL:

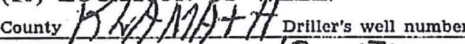
14 1/4 Section $/ 2$ T. 3 R. 92 w.M. Bearing and distance from section or subdivision corner (11) WATER LEVEL: Completed well.

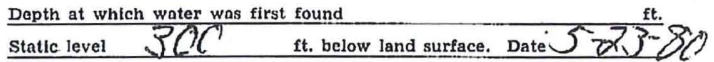

Artesian pressure lbs. per square inch. Date

(12) WELL LOG: Diameter of well below casing ....................

Depth drilled 3.55 ft. Depth of completed well $3.5 \mathrm{jt}$.

Formation: Describe color, texture, grain size and structure of materials; and show thickness and nature of each stratum and aquifer penetrated, with at least one entry for each change of formation. Report each change in position of Static Water Level and indicate princlpal water-bearing strata.

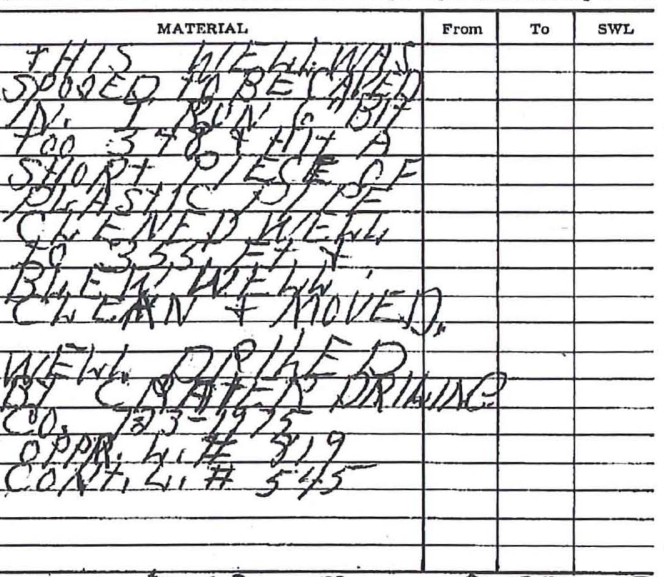

Work started $5-22$ 10 80 completed $5-2 \sqrt{381}$ Date well drilling machine moved off of well $5-2,31080$

Drilling Machine Operator's Certification:

This well was constructed under my direct supervision. Materials used and information reported above are true to $m$

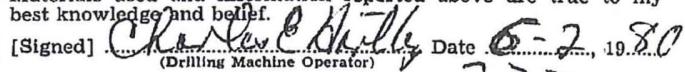
Drilling Machine Operator's License No. ....

Water Well Contractor's Certification:

This well was drilled under my jurisdiction and this report is true to the best of my knewledga and belief

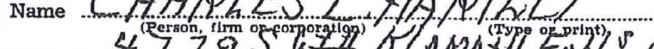

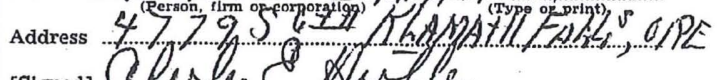

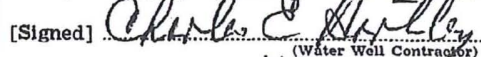
Contractor's License No $/ 45$..... Date .......6............., 19..8. 
NOTIYCE TO WATER WELL CONTRACTOR

The original and first copy of this report

are to be filed with the

WATER RESOURCES DEPARTMENT.

SALEM, OREGON 97310

of well completion.
WATER WILLC REPORT

STATE OF OREGON

(Please type or print)

Do not write above this line) $7 / 5$ state well No. $37 \leq / 9 E-78 \mathrm{~cd}$

State Permit No.

\section{(1) OWNER:}

Name Douglas. Famam

Address P.0, Box-95 Macdoe1, Calif

(2) TXPE OF WOKK (check):

New Well $\square \quad$ Deepening $\square \quad$ Reconditioning $\square \quad$ Abandon $\square$ If abandonment, describe material and procedure in Item 12.

(3) TYPE OF WELL: (4) PROPOSED USE (check): \begin{tabular}{ll|ll} 
Rotary \\
Cable
\end{tabular} Dug $\square$ Bored $\square \quad$ Irrigation $y$ Test well $\square$ Other

CASING INSTALLED:

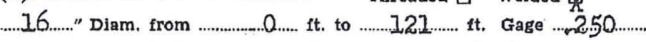

Dinm from

int. to

ft. Gage

." Dlam. from

PERFORATIONS:

Type of perforator used

Perforated? पKYes $\square$ No.

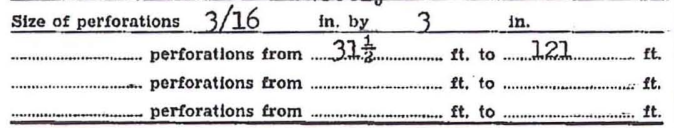

(7) SCREENS:

Well screen installed? $\square$ Xes, No

Manufacturer's Name

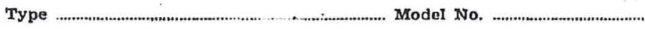

Dtam. ............... Slot size ............... Set from .................... ft. to .................. 1t.

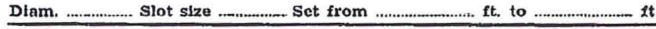

(8) WELL TESTS: $\begin{aligned} & \text { Drawdown is amount water level is } \\ & \text { lowered below static levelvalley }\end{aligned}$

Was a pump test made? 60 Yes $\square$ No If yes, by whom? pump

\begin{tabular}{llllll}
\hline Nield: 775 & gal./min. with 95 ft. drawdown after & 4 & hrs. \\
\hline Bailer test & gal./min. with & ft. drawdown after & hrs. \\
\hline Artesian flow & g.p.m. & & & \\
\hline mperature of water 42 & Depth artesian flow encountered ................. ft. \\
\hline
\end{tabular}

(9) CONSTRUCTION:

Well seal-Material used ..........eement.

Well senled from land surface to ……18

Dlameter of well bore to bottom of seal .........20................ in.

Diameter of well bore below seal .........16.............. in.

Number of sacks of cement used in well seal ........1.

How was cement grout placed? ....grout pipe.

. 1 - n -

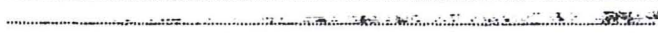

Was a drive shoe used? IXYes $\square$ No Plugs ........... Size: location ........... ft.

Dld any strata contain unusable water? $\square$ Yes XNo

Type of water?

depth of strata

Method of sealing strata off

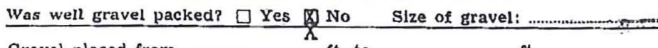

Gravel placed from ft. to

\section{(10) LOCATION OF WELL:}

County Wlamath Driller's well number

S.E. 1/4 S. W/ Section 28 T. $32 \mathrm{~S}$ R. 9E

Rearing and distance from acction or subdivision corner

(11) WATER LEVEL: Completed well.

Depth at which water was first found 38

Static level 5 ft. below land surface. Date $2 / 11 / 79$

Artesian pressure lbs. per square inch. Date

(12) WELL LOG: Diameter of well below casing ...16"...............

Depth drilled 301 ft. Depth of completed well 250

Formation: Describe color, texture, grain size and structure of materials and show thickness and nature of each stratum and aquifer penetratec with at least one entry for each change of formation. Report each change in position of Static Water Level and indicate principal water-bearing strata.

\begin{tabular}{|c|c|c|c|}
\hline MATERIAL & From & To & sWL \\
\hline top soil & 0 & $7 \frac{1}{2}$ & \\
\hline Dumic \& clay & $7 \frac{1}{3}$ & 38 & \\
\hline pumac, sand \& gravel & 38 & 43 & 5 \\
\hline gray clay & 43 & 45 & $"$ \\
\hline layexs-of sand, grave]\&clay & 45 & 67 & $"$ \\
\hline brown clay & 67 & 97 & $"$ \\
\hline brown sand grave l\&clay & 97 & 103. & $"$ \\
\hline brown clay & 103 & 734 & "1 \\
\hline brown sand, pumic \& clay & 134 & 778 & $"$ \\
\hline gxay basalt & 178 & 245 & $\mathrm{X}$ \\
\hline brown \& gray lava & 245 & 277. & " \\
\hline layers of gray hasalt, brown & & & \\
\hline lava \& clay & 277 & 294 & $n$ \\
\hline gray basalt $6 \mathrm{f}$. & $\frac{1294}{11}$ & 301 & $"$ \\
\hline . dUL & & & \\
\hline WATER RESCURCFS & & & \\
\hline 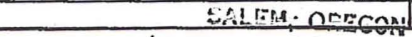 & & & \\
\hline lork started $5 / 2$ & & & 19 \\
\hline
\end{tabular}

Date well drilling machine moved off of well 7/11

Drilling Machine Operator's Certification:

This well was constructed under my direct supervision. Materials used and hformation reported algove are true to my best knowledge and beligf:

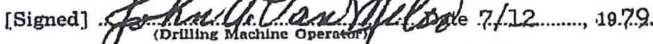

Drilling Machine Operator's License No. ........118...

\section{Water Well Contractor's Certification}

This well was drilled under my jurisdiction and this report is true to the best of my knowledge and belief.

Name John A. Van Meter

(Person, firm or corporation) (Type or print)

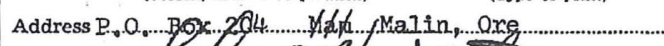

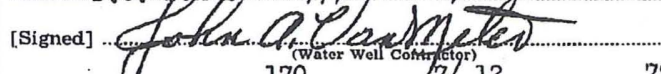

Contractor' 170 (water well conthe 12 
NOTICE TO WATER WELL CONTRACTOR

The original and first copy of this report are to be flled with the

WATER RESOURCES DEPARTMENT, SALEM, OREGON 97310 within 30 days from the date
WATER WILTU RERORT

S'TATE OF OREGON

(Plgage po or print)

one this it

(Do not write above dinCES STPT. $\mathrm{K} \operatorname{lam}$ state well no. $325 / 9 E-176 a$
$\eta 13$ state Permit no.
(1) OWNER:

Name Douglas $\mathrm{y}_{\text {- Osborne }}$ Address6536 Climax Klamath Falls, Ore.

(2) TXPE OF WORK (check):

New Well 造 Deepening $\square \quad$ Reconditioning $\square$ Abandon $\square$ If abandonment, describe material and procedure in Item 12.

(3) TYPE OF WELL: (4) PROPOSED USE (check): Rotary Driven $\square$ Domestic $\square$ Industrlal $\square$ Municipal Dug $\square$ Bored $\square \quad$ Irrigation 百 Test Well $\square$ Other

(5) CASING INSTALLED: Threaded $\square$ Wolded 长 12 ..." Dlam. from ................. ft. to ....... 58 ft..... fage ....219

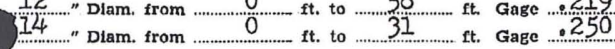
." Dlam. from ft. to ft. Gage

(6) PERFORATIONS: Perforated? 叉 Yes $\square$ No

Thype of perforator used factory

le of perforations $3 / 16$ in. by 3 in.

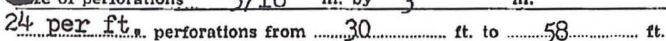

.............................. perforations from ............................... ft. to .............................. ft.

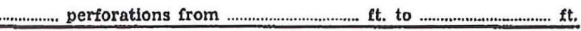

(7) SCREENS: Well screen installed? $\square$ Yes $\square^{X}$ No

Manufacturer's Name ..............................................................................................................

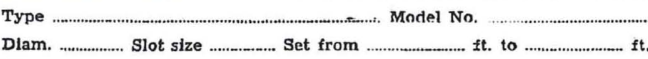

Diam. ............... Slot slze ............... Set from ...................... ft. to ...................... ft.

(8) WELL TESTS: $\quad \begin{aligned} & \text { Drawdown is amount water level is } \\ & \text { lowered below static level }\end{aligned}$

Was a pump test mado? 嘀 Yes Yield: 1950 gal./min. with 29 ft. drawdown after 2 hrs

\begin{tabular}{|c|c|c|c|}
\hline " & $"$ & $"$ & $"$ \\
\hline & $"$ & $" \prime$ & $"$ \\
\hline - er test & gal./min. with & ft. drawdown after & hrs. \\
\hline \multicolumn{4}{|l|}{ Arteslan now } \\
\hline Temperature & Depth arte & flow encountered ...... & $\ldots$ it. \\
\hline
\end{tabular}

\section{CONSTRUCTION:}

seal-Material used eement...

Well sented from land surface to 18

Diameter of well bore to bottom of seal 17 . $12 \ldots \ldots . . . . . . . . . .$. in.

Diameter of well bore below seal ...................... in.

Number of sacks of cement used in well seal ${ }^{2}$.

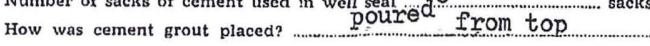

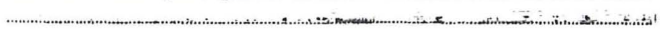

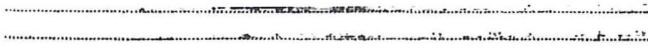

Was a drive shoe used? X $\square$ Yes $\square$ No Plugs ............ Siże: location ............ ft. Dld any strata contain unusable water? $\square$ Yes $X_{\text {No }}$

Type of water? depth of strata

Method of sealing strata of

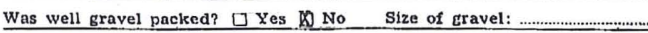

Gravel placed from

\section{(10) Ế̉CATION OF WELL:}

County KIamath 1 rprlller's well number

N.W. W N.E. Section 325 T. $32 \mathrm{~S}$ R. 9R-

W.M.

Bearing and distance from section or subdivision enrner.

(11) WATER LEVEL: Completed well.

Depth at which water was first found 6
Static level
6

Artesian pressure lbs. per square inch. Date

(12) WELL LOG: Dlameter of well below casing 12 Depth drilled $105 \quad \mathrm{ft}$. Depth of completed well $104 \mathrm{it}$

Formation: Describe color, texture, grain size and structure of materials: and show thickness and nature of each stratum and aquifer penctrated, with at least one entry for each change of formation. Report erch change in position of Static Water Kevel and indleate principal water-bearing strata.

\begin{tabular}{|c|c|c|c}
\hline MATERIAL & From & To & swL \\
\hline top soll & 0 & 1 & \\
\hline
\end{tabular}

top soil

pink pumic

coarse sand \& white pumic

black clay

red lava

coarse sand \& clay

gray babbly lava

sand \& gravel

cemented gravel

fine black sana

\begin{tabular}{l|l|l|l}
\hline & 84 & 104 & " \\
\hline & 104 & 105 & " \\
\hline & & & \\
\hline & & & \\
\hline & & & \\
\hline & & & \\
\hline & & & \\
\hline & & & \\
\hline & & & \\
\hline & & & \\
\hline
\end{tabular}

\begin{tabular}{lllll}
\hline Work started $7 / 31$ & 1978 Completed $8 / 26$ & 1978
\end{tabular}

Date well drilling machine moved off of well $8 / 26 \quad{ }_{19}^{78}$

Drilling Machine Operator's Certification:

This well was constructed under my direct supervision. Materials used and information/reported above are true to my

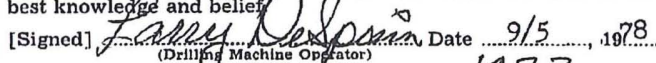

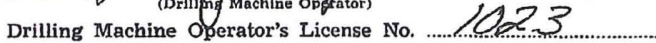

Water Well Contractor's Certification:

This well was drilled under my jurisdiction and this report is true to the best of my knowledge and belief.

Name .....John ...As...Van...Meter.

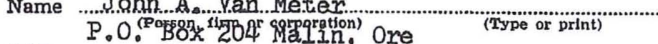

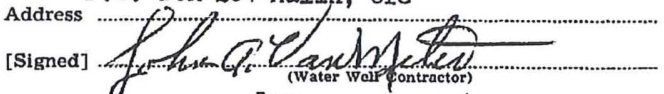

Contractor's License No. 170 ...... Date ........9/.5................ 19.78 


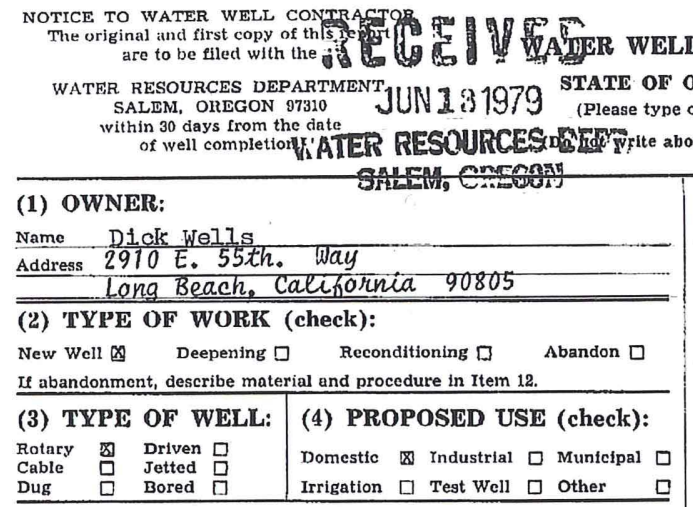

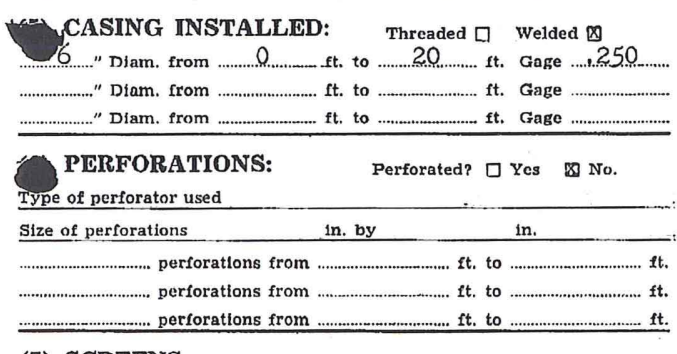

(7) SCREENS: Well screen installed? $\square$ Yes

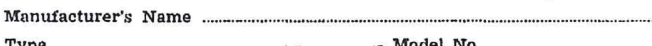

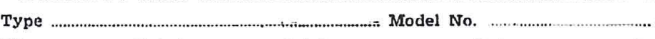

Dlam. ............... Slot size ............... Set from ....................... ft. to ....................... ft.

Dlam. ............... Slot size ............... Set from ..................... ft. to ..................... ft.

(8) WELL TESTS: $\quad \begin{aligned} & \text { Drawdown is amount water level is } \\ & \text { lowered below static level }\end{aligned}$

Was a pump test made? 四 Yes $\square$ No if yes, by whom? Driller Yleld: $20 \quad$ gal./mln. with 65 ft. drawdown after 1 hrs.

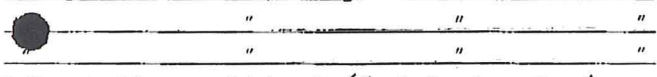

Bailer test $20 \quad$ gal. $/ \mathrm{min}$. with 65 ft. drawdown after $1 \mathrm{hrs}$. Artesian flow g.p.m.

Temperature of water 48 Depth arteslan flow encountered .................... ft.

\section{(9) CONSTRUCTION:}

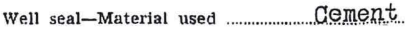

Well sealed from land surface to

Diameter of well bore to bottom of seal .................... in.

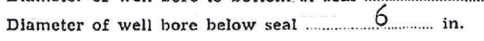

Number of sacks of eement used in well seal .................. 13

well seal ............................- sack

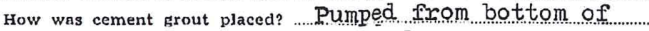
casing .... to... to the ground surface.

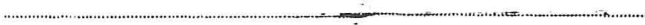

Was a drive shoe used? $\square$ Yes $\otimes$ No Plugs ....... Size: location ............ it. Did any strata contain unusable water? $\square$ Yes 0 No

Type of water? depth of strata

Method of senling strata off

Was well gravel packed? 口 Yes $\otimes$ No Size of gravel: ..........................

Gravel placed from .......................... ft. to ……............... ft.
State well No. $335 / 9 E-33 \mathrm{dd}$

State Permit No.

\section{(10) LOCATION OF WELL:}

County Klamath_Driller's well number

SE $1 / 4 \mathrm{NW} \quad 1 / 4$ Section 33 T. $33 \mathrm{~S}$ R. 9E $\quad$ W.M.

Bearing and distance from section or subdivision corner

(11) WATER LEVEL: Completed well.

Depth at which water was first found $170 \mathrm{ft}$ \begin{tabular}{llll}
\hline Static level & 155 & ft. below land surface. Date 5-9-79 \\
\hline
\end{tabular} Artesian pressure lbs. per square inch. Date

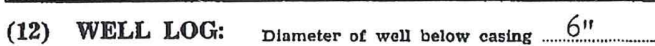
Depth drilled 265 ft. Depth of completed well $265 \mathrm{ft}$. Formation: Describe color, toxture. grain size and structure of matertals; and show thickness and nach posittion of Static Water Level and indicate principal water-bearing strata.

\begin{tabular}{c|c|c|c|}
\hline MATFRIAL & From & To & SWL \\
\hline
\end{tabular}

\begin{tabular}{l|r|r|r}
\hline Top Soil \& Boulders & 0 & 4 & \\
\hline Brown Glay \& Boulders & 4 & 13 & \\
\hline
\end{tabular}

Herrd Black Ia

Hard Brown Tava Rock

Brown Rock \& Clay

Hard Black I,ava Rock

Brown Rock \& clay

Med, Hard Brown Taye Rock

Firm Brown Sandrock

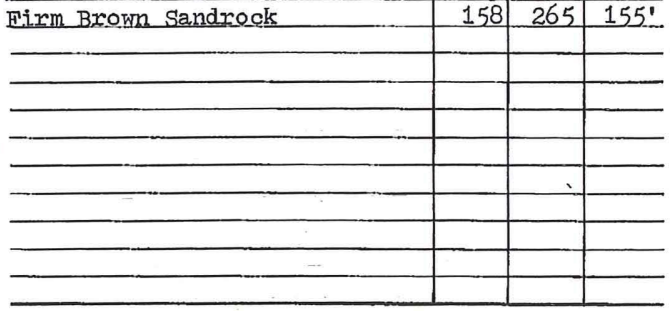

\begin{tabular}{llllll}
\hline Work started & $5-4-79$ & 10 & Completed & $5-9$ & 1979
\end{tabular} $\begin{array}{lll}\text { Date well drilling machine moved off of well } & 5-9 & 1979\end{array}$

Drilling Machine Operator's Certification:

This well was constructed under my direct supervision. Materials used and information reported above are true to my

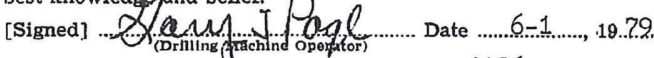
Drilling Machine Operator's License No. ........1186

\section{Water Well Contractor's Certification:}

This well was drilled under my jurisdiction and this report is true to the best of my knowledge and belief.

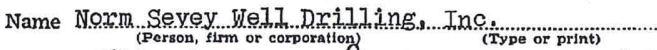

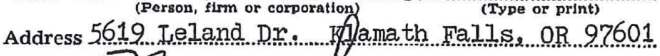
[Signed]

Contractor's License No. 408 ..... Date ........................., 19.7.9. 